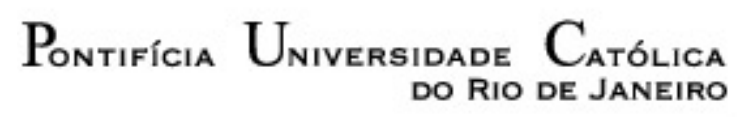

Francinete Nascimento dos Santos

\author{
Para Além dos Muros da Escola: \\ Memória Crítica de Práticas e \\ Experiências Pedagógicas
}

Dissertação de Mestrado

Dissertação apresentada ao Programa de Pós-graduação em Literatura, Cultura e Contemporaneidade da PUC-Rio como requisito parcial para obtenção do título de Doutor em Letras/ Literatura, Cultura e Contemporaneidade.

Orientadora: Profa. Patricia Gissoni de Santiago Lavelle Co-orientador: Prof. Alexandre Montaury Baptista Coutinho 
FRANCINETE NASCIMENTO DOS SANTOS

\title{
Para Além dos Muros da Escola: Memória Crítica de Práticas e Experiências Pedagógicas
}

\begin{abstract}
Dissertação apresentada como requisito parcial para obtenção do grau de Mestre pelo Programa de PósGraduação em Literatura, Cultura e Contemporaneidade da PUC-Rio. Aprovada pela Comissão Examinadora abaixo.
\end{abstract}

Profa. Patricia Gissoni de Santiago Lavelle

Orientadora

Departamento de Letras - PUC-Rio

Prof. Alexandre Montaury Baptista Coutinho

Coorientador

Departamento de Letras - PUC-Rio

Profa. Marília Rothier Cardoso

Departamento de Letras - PUC-Rio

Profa. Maria Cristina Cardoso Ribas

UERJ

Rio de Janeiro, 26 de abril de 2019. 
Todos os direitos reservados. É proibida a reprodução total ou parcial do trabalho sem autorização da universidade, da autora e do orientador.

\section{Francinete Nascimento dos Santos}

Graduada em Letras - Português/Inglês pela Faculdades Integradas Campo-Grandenses , RJ, Brasil em 1989. Especialista em Docência do Ensino Superior. Pela Fundação Educacional Unificada Campo-Grandense, FEUC, Brasil em 2000. Especialização em Administração Escolar pela Universidade Castelo Branco, UCB/RJ, Brasil em 1996. Mestre em Literatura, Cultura e Contemporaneidade pela PUC-Rio em 2019. Atua como professora da Rede Pública desde 1990, concursada pela Prefeitura de Itaguaí/Seropédica desde 1990 em Língua Portuguesa; atua como professora concursada pela Prefeitura de Piraí desde 2001 em Língua Portuguesa e atua também com Língua Inglesa; atuou como professora do Estado de 1990 até 2006 ministrando aulas de Língua Inglesa e de Língua Portuguesa.

Ficha Catalográfica

Santos, Francinete Nascimento dos

Para Além dos Muros da Escola: Memória Crítica de Práticas e Experiências Pedagógicas / Francinete Nascimento dos Santos; orientadora: Patricia Gissoni de Santiago Lavelle; co-orientador: Alexandre Montaury Baptista Coutinho. - 2019.

146 f.: il. color. ; $30 \mathrm{~cm}$

Dissertação (mestrado) - Pontifícia Universidade Católica do Rio de Janeiro, Departamento de Letras, 2019.

Inclui bibliografia

1. Letras - Teses. 2. Patricia Gissoni de Santiago Lavelle. 3. Alexandre Montaury Baptista Coutinho. 4. Projetos de Promoção de Leitura. 5. Educação de Jovens e Adultos. 6. Práticas Pedagógicas no Ensino Público. I. Lavelle, Patricia Gissoni de Santiago. II. Coutinho, Alexandre Montaury Baptista. III. Pontifícia Universidade Católica do Rio de Janeiro. Departamento de Letras. IV. Título. 
Dedico a Deus princípio e fim de todas as coisas, meu tudo. 


\section{Agradecimentos}

Agradeço ao meu marido Mario César Nogueira Batista pelo apoio.

Ao meu filho Carlos Henrique dos Santos Lins por ser um filho maravilhoso.

A CAPES e a PUC-Rio pelo auxílio concedido.

A minha Orientadora Dra. Patrícia Lavelle pela confiança.

Ao meu co-orientador Dr. Alexandre Montaury pelo apoio e incentivo.

A minha querida professora Dra. Marília Rothier por ter a paciência de me conduzir pelos caminhos da escrita acadêmica.

A Doutora Maria Cristina Ribas pelo incentivo e orientações passadas no exame de qualificação.

Ao Doutor Renato Pontes do Departamento de Educação por se tornar um amigo querido.

A Masé Lemos por nos proporcionar um brilhante ensinamento sobre Poesias.

A todos os professores e funcionários do Departamento de Letras.

A Lara (in memorian) amiga e incentivadora que perdemos ao longo do caminho.

Ao meu médico Doutor Wesley Salmont Ávila por me fazer redescobrir o prazer de viver. 


\section{Resumo}

Santos, Francinete Nascimento dos; Lavelle, Patricia Gissoni de Santiago (Orientadora); Coutinho, Alexandre Montaury Baptista (Co-orientador). Para Além dos Muros da Escola: Memória Crítica de Práticas e Experiências Pedagógicas. Rio de Janeiro, 2019. 146p. Dissertação de Mestrado - Departamento de Letras, Pontifícia Universidade Católica do Rio de Janeiro.

Essa Dissertação de Mestrado, que traz como título "Para Além dos Muros da Escola: Memória Crítica de Práticas e Experiências Pedagógicas”, traz como temática experiências ligadas à promoção de leitura em escolas. Trata-se de uma pesquisa de natureza qualitativa, fundamentada na experiência da autora, apoiando-se em autores como Le Goff, Walter Benjamim, Foucault, Didi Huberman, Paulo Freire, Alan da Rosa, que se encontram envolvidos em escritas que versam sobre memórias coletivas e individuais. A pesquisa examina as memórias formadas pela vivência cultural dos alunos que participaram de projetos e eventos criados e desenvolvidos para a promoção da leitura, numa abertura de novos caminhos para o mundo da escrita. Ela parte, assim, de descrições de imagens e relatos dessas práticas que renovaram as diferentes modalidades de ensino da Educação Básica nas escolas municipais "Panaro Figueira”, localizada em Seropédica - RJ, e no “Colégio Municipal Doutor Aurelino Gonçalves Barbosa”, localizado em Piraí - Rio de Janeiro. Essas práticas foram desenvolvidas na maioria das vezes com a Educação de Jovens e Adultos; com o apoio da Educação Infantil, Ensino Fundamental e Ensino Médio entre os anos 2000 a 2018. Tiveram como objetivo fortalecer a interação, a interdisciplinaridade e a interlocução entre os envolvidos. Os objetivos foram desenvolvidos de maneira exploratória com apresentação de dados e relatos próprios, e outros coletados com os indivíduos que fizeram parte desse processo. Nesse processo a interação e os laços de amizade foram o ápice desse trabalho interdisciplinar.

\section{Palavras-chaves}

Projetos de Promoção de Leitura; Educação de Jovens e Adultos; Práticas Pedagógicas no Ensino Público. 


\section{Abstract}

Santos, Francinete Nascimento dos; Lavelle, Patricia Gissoni de Santiago (Advisor); Coutinho, Alexandre Montaury Baptista (Co-advisor). Reading promotion projects; Youth and adult education; Pedagogical practices in public education. Rio de Janeiro, 2019. 146p. Dissertação de Mestrado - Departamento de Letras, Pontifícia Universidade Católica do Rio de Janeiro.

This master's dissertation, entitled "Beyond the School Walls: Critical Memory of Practices and Pedagogical Experiences”, brings as theme experiences related to the promotion of reading in schools. It a research of a qualitative nature, based on the author's experience, supported by author's such as Le Goff, Walter Benjamin, Foucault, Didi Huberman, Paulo Freire, Alan da Rosa who are involved in writings dealing with collective and individual. The research examines the memories formed by the cultural experiences of students who participated in projects and events created are developed for the promotion of reading, opening new paths to the world of writing. It starts with description of images and relates of these practices that renewed the different modalities of education of basic education in municipal school "Panaro Figueira", located in Seropédica - Rio de Janeiro, and in the "Municipal School Dr. Aurelino Gonçalves Barbosa”, located in Piraí - Rio de Janeiro. These practices were mostly developed with the "Youth and Adult Education", with the support of Children's Education, Elementary Education and Secondary Education between the years 2000 and 2018. They aimed to strengthen interaction, interdisciplinary and interlocution among those involved. The objectives were developed in a exploratory way with the preservation of data and own reports, and others collected with the individuals who were part of this process. In this process the interaction and the bonds of friendship were consolidated, becoming thus the apice of this interdisciplinary work.

\section{Keywords}

Reading promotion projects; Youth and adult education; Pedagogical practices in public education. 


\section{Sumário}

1. Introdução 15

2. Historiografia 27

2.1 - Práticas que renovam os caminhos da leitura e da escrita 27

2.2 - Fotografias, memórias e histórias 30

2.3 - As imagens e as suas finalidades $\quad 55$

2.4 - As imagens como perpetuação do tempo e da história 58

$\begin{array}{ll}2.5 \text { - A imagem transpondo o tempo } & 60\end{array}$

2.6 - A imagem sobrevivente e a dupla distância 63

3. As práticas pedagógicas através de projetos 70

3.1 - Prática educativa desenvolvida pela turma do $2^{\circ}$ ano E.M. 76

3.2 - As turmas de EJA - uma viagem no espaço escolar 78

4 - Projetos de Leitura $\quad 86$

4.1 - Passeios culturais - janela para o mundo 86

4.2 - Enriquecendo o conhecimento -danças, peças teatrais, criação de paródias $\quad 96$

4.3 - Pedagoginga na educação - as danças 104

4.4 - Saraus, varaus de poesia e chá literário 110

4.5 - Fotos e imagens de danças performáticas, gincanas e artes visuais desenvolvidos pelos alunos

5. Leituras escrita e oral 124

5.1 - O contador de histórias $\quad 124$

5.2 - Projeto de incentivo a leitura 134

$\begin{array}{ll}\text { 6. Conclusão } & 138\end{array}$

7. Referências Bibliográficas 141

8. Anexos 144 


\section{Ilustrações, imagens e figuras}

Figura 1 - EJA, Ensino Médio e Ensino Fundamental - Peça Teatral 2017

Figura 2 - Turmas da EJA da Escola Municipal Panaro Figueira com a professora de geografia Fernanda montando as pinturas em guache que seriam utilizadas na feira cultural

Figura 3 - Painel em guache montado pelo Ensino Fundamental I na aula de Artes do C. M. Dr. Aurelino G. Barbosa - Piraí

Figura 4 - Pintura com guache feita pelos alunos do Ensino Fundamental I do C. M. Dr. Aurelino G. Barbosa - Piraí

Figura 5 - Os alunos do C. M. Dr. Aurelino G. Barbosa se apresentando em uma confraternização

Figura 6 - Funcionários do C. M. Dr. Aurelino G. Barbosa em uma Confraternização - 2015

Figura 7 - Foto tirada após o Desfile Cívico do C. M. Dr. Aurelino G. Barbosa professores, funcionários e Prefeito - 2014

Figura 8 - Professores de ciências e alunos na Feira Estadual de Ciências $-2015$

Figura 9 - alunos do Ensino Fundamental I do C. M. Doutor Aurelino G. Barbosa - Painel de imagens

Figura 10 - Fanfarra do C. M. Doutor Aurelino G. Barbosa

Figura 11 - Desfile Cívico da E. M. Panaro Figueira no Campus da UFRRJ - 2012

Figura 12 - Desfile Cívico na Comunidade de Cacaria Piraí - 2012

Figura 13 - Desfile Cívico do C. M. Doutor Aurelino G. Barbosa na Comunidade de Cacaria - Piraí - 2017

Figura 14 - Alunos do Ensino Fundamental I em 2010 - Hoje estão no Ensino Médio - 2019

Figura 14 - Alunos do E. Médio junto com alunos do E. Fundamental em uma representação cultural - 2016

Figura 15 - Alunos da EJA e do Ensino Médio na Gincana Cultural - 
Figura 16 - Alunos de diferentes escolas, de diferentes série em visita ao Tour da Copa montado pela Coca-Cola no Maracanã

Figura 17 - Passeio ao Teatro Municipal do Rio de Janeiro com alunos do Ensino Fundamental I e II - C. M. Dr. Aurelino G. Barbosa

Figura 18 - Dança da música Aquarela do Brasil desenvolvida pelos alunos da EJA da Escola Municipal Panaro Figueira - Ano 2011

Figura 19 - Dança Caipira Maluca C. M. Doutor Aurelino G. Barbosa Festa Junina - ANO - 2013

Figura 20 - Dança Caipira Maluca - Festa Junina - ANO - 2013

Figura 21 - Releituras em desenhos de obras de Arte confeccionadas por alunos do E. Fundamental II

Figura 22 - Painel com imagem do Rio de Janeiro - pintado por um aluno do Ensino Fundamental II do C. M. Doutor Aurelino G. Barbosa

Figura 23 - Desenhos e Makets feitas pela EJA da E. M. Panaro Figueira

Figura 24 - Formatura da EJA Escola Municipal Panaro Figueira - 2010

Figura 25 - Formatura da EJA Escola Municipal Panaro Figueira - 2010

Figura 26 - Formatura da EJA e do Ensino Médio do C. M. Doutor Aurelino G. Barbosa - 2017

Figura 27 - E. M. Panaro Figueira - Dança apresentada pela EJA Professora Sabrina (Educação Física)

Figura 28 - E. M. Panaro Figueira - preparação para apresentação da música Aquarela do Brasil

Figura 29 - Quadro do museu de Petrópolis batalha da Independência

Figura 30 - Foto das carruagens antigas no Museu de Petrópolis

Figura 31 - Quadro de Carmem Miranda em um momento glorioso da sua vida - Museu de Petrópolis

Figura 32 - Foto de um desfile cívico em que as crianças carregam consigo uma lista de ingredientes para realizar um sonho de criança, isso é poesia para os olhos...

Figura 33 - Projeto “Escola Aberta” em Seropédica - ano 2005 
Figura 35 - Oficina de Taekwondo no projeto 'Escola Aberta' - Ano 2005

Figura 36 - Oficina de capoeira no projeto ‘Escola Aberta’ - Ano 2005

Figura 37 - Foi montada uma barraca com motivos das cores do Brasil. $\quad 75$

Figura 38 - Um Banner explicativo sobr a região e os atletas 77

Figura 39 - Turma do Ensino Noturno do Colégio Municipal Doutor Aurelino G. Barbosa

Figura 40 - Professores da EJA e do Ensino Médio - 2010

Figura 41 - Turmas da EJA da Escola Municipal Panaro Figueira 79

Figura 42 - Turmas da EJA da Escola Municipal Panaro Figueira 80

Figura 43 - Alunos, professores e comunidade escolar assistindo a apresentação dos trabalhos desenvolvidos pela EJA da Escola Municipal Panaro Figueira

Figura 44 - Alunos, professores e comunidade escolar assistindo a apresentação dos trabalhos desenvolvidos pela EJA da Escola Municipal Panaro Figueira

Figura 45 - Diretor, alunos, coordenadora da EJA da Escola Municipal Panaro Figueira em celebração pelo final das apresentações dos trabalhos desenvolvidos na Culminância dos Projetos. Momento ímpar...

Figura 46 - Alunas do C. M. Dr. Aurelino G. Barbosa caracterizados para se apresentarem no FEMUPI - Festival de Paródia

Figura 47 - Alunas do C. M. Dr. Aurelino G. Barbosa apresentando-se no FEMUPI de Piraí

Figura 48 - Apresentação da dança no Colégio Municipal Doutor Aurelino G. Barbosa

Figura 49 - Apresentação da dança do Colégio Municipal Doutor Aurelino G. Barbosa em Piraí.

Figura 50 - Alunos na visitação a Bienal do Livro no Rio de Janeiro 2018

Figura 51 - Professores e Orientadores Educacionais e Pedagógicos na visitação junto com os alunos na BIENAL

Figura 52 - RIO + 20 - Visita a um dos stands com o C. M. Dr. Aurelino G. Barbosa - 2012 
Figura 53 - Passeio a Rio + 20 - C. M. Dr. Aurelino G. Barbosa - 2012

Figura 54 - Passeio com o $6^{\circ}$ ano ao monumento de São João Marcos 90

Figura 55 - Maket da cidade de São João Marcos antes da destruição

Figura 56 - Alunos e professores caminhando junto como o guia turístico pelos destroços da cidade

Figura 57 - Passeio cultural em Petrópolis com as turmas de EJA e Ensino Médio

Figura 58 - Locomotiva Princesa Leopoldina em Petrópolis

Figura 59 - Visitação ao Museu de Petrópolis

Figura 60 - Visitação ao museu de Petrópolis

Figura 61 - Representação da religiosidade de raízes africanas - E.M. Panaro Figueira

Figura 62 - Aluno da EJA da E. M. Panaro Figueira em uma representação de dança africana

Figura 63 - Representação de danças folclóricas de diferentes regiões do Brasil - EJA Panaro Figueira

Figura 64 - Barraca montada e ornamentada pelos alunos do Ensino Médio com o auxílio das professoras Helena de história e a professora Rosemar de inglês

Figura 65 - Barraca montada e ornamentada pelos alunos de EJA e Ensino Médio

Figura 66 -Ensino Fundamental I na apresentação na cantata de natal na praça- 2018

Figura 67 - Ensino Fundamental I em uma representação na cantata de natal na praça- 2018

Figura 68 - Ensino Fundamental I em uma representação na cantata de natal na praça- 2018

Figura 69 - Dança do pau de fita - preparação para a apresentação ao público - FESTEJA

Figura 70 - Dança do pau de Fita - apresentação do C. M. Dr. Aurelino no Festeja de Piraí - 2011 
Figura 71 - Apresentação da dança do pau de fita do Colégio M. Doutor Aurelino G. Barbosa na Escola municipal Panaro Figueira levados pela professora Francinete e Celia Polati - 2011

Figura 72 - Apresentação de dança da Panaro Figueira no FESTEJA de Seropédica - 2012

Figura 73 - Dança Folclórica - Piraí - 2014

Figura 74 - Dança Folclórica - Piraí - 2014

Figura 75 - Declamação de poesia por uma aluna do Ensino Médio C. M. Doutor Aurelino G. Barbosa - 2017

Figura 76 - Declamação de poesia por uma aluna do Ensino Médio C. M. Doutor Aurelino G. Barbosa - 2018

Figura 77 - Trabalho das Turmas da EJA da Escola Municipal Panaro Figueira na Culminância do Projeto sobre Africanidade - 2009

Figura 78 - Trabalho das Turmas da EJA da E. M. Panaro Figueira na Culminância do Projeto sobre Africanidade - 2009

Figura 79 - Mesa de variedades para o chá literário

Figura 80 - As aulas de Ciências em movimento pela Preservação Ambiental

Figura 81 - Plantas medicinais colhidas e levadas pelos alunos da EJA -

Figura 82 - Trabalhos artísticos desenvolvidos pelos alunos com o auxílio da professora de Artes Celly Flávia

Figura 83 - Trabalhos artísticos desenvolvidos pelos alunos com o auxílio da professora de Artes Celly Flávia

Figura 84 - Trabalhos artísticos desenvolvidos pelos alunos com o auxílio da professora de Artes Celly Flávia

Figura 85 - Trabalhos artísticos desenvolvidos pelos alunos com o auxílio da professora de Artes Celly Flávia

Figura 86 - Trabalhos artísticos desenvolvidos pelos alunos com o auxílio da professora de Artes Celly Flávia

Figura 87 - Trabalhos artísticos desenvolvidos pelos alunos com o auxílio da professora de Artes Celly Flávia 
Figura 89 - Gincana desenvolvida com o Ensino Fundamental $6^{\circ}$ ao $9^{\circ}$ ano sob a orientação da professora de Educação Física Célia Polati - ano 2013

Figura 90 - Brincadeira passa ou repassa participação das turmas Ensino Fundamental; Ensino Médio e EJA

Figura 91 - Gincana interdisciplinar - time vermelho - 2016

Figura 92 - Gincana Consolidando Amizades. Trabalho desenvolvido na Gincana Interdisciplinar do C. M. Doutor Aurelino G. Barbosa 2017

Figura 93 - professora Francinete e alunos do Ensino Médio e da EJA Educação de Jovens e Adultos - 2017

Figura 94 - Professora Rosemar Pereira da Silva em uma de suas vestimentas

Figura 95 - Professora Maria Aparecida (Cidinha) e Eliza com alunos da Educação Infantil caracterizadas com roupas dos anos 80 - realizado no ano de 2015

Figura 96 - Professora Rosemar vestida de Emília do Sítio do Pica Pau Amarelo

Figura 97 - Professora Rosemar representando uma Princesa

Figura 98 - apresentação de peça teatral ' $\mathrm{O}$ rico e o pobre' pelas alunas do Ensino Fundamental

Figura 99 - Alunos cantando e tocando em um evento no C.M.D. Aurelino

Figura 100 - Festa Junina com brincadeira e dança com os alunos da Educação Infantil

Figura 101 - Festa Junina brincadeira e dança com alunos do Ensino Fundamental

Figura 102 - Tarefa coreografada da gincana da amizade (Ensino Médio e Educação de Jovens e Adultos)

Figura 103 - escritor e autor Jeferson Sarmento 


\section{Introdução}

O tema "Para além dos muros da escola: memória crítica de experiências pedagógicas” mostra que formar leitores na atualidade é um desafio; um desafio que requer uma criatividade que deve vir permeada de incentivos e de condutividade. No espaço escolar, 'mesmo aqueles alunos que ainda não tiveram aulas ministradas por mim, já iniciam o ano letivo perguntando se eles irão a Bienal do Livro’. Esse interesse por parte dos alunos continua sendo para mim enquanto educadora um impulsionador para a criação de eventos que trazem como fator principal a promoção de leitura no espaço escolar. Essa promoção de leitura já toma corpo no início do ano letivo, com uma ação do Projeto Político Pedagógico que traz a 'Semana da Leitura' como um desafio para iniciar o ano com o trabalho de incentivo a leitura que envolve todos os alunos da escola. Desde a Educação Infantil até o Ensino Médio, nesse contexto, surge também o professor caracterizado que se torna 'O contador de histórias'.

A Educação Infantil, que é considerada pela Lei de Diretrizes e Bases da Educação Nacional, nº 9394/96 como a primeira etapa da Educação Básica, de forma que essa ofereça visibilidade ao trabalho pedagógico com a criança de 0 a 6 anos, e procure atender primordialmente às especificidades do desenvolvimento dessas crianças que se encontram nessa faixa etária contribuindo assim, para a construção de uma aprendizagem que visa o exercício de sua cidadania. Essa perspectiva tornou-se Lei com a aprovação em 2001 do Plano Nacional de Educação (PNE), que traz em seu bojo um objetivo comum que é garantir os direitos da criança a aprendizagem; entre esses direitos encontra-se o direito à educação.

As propostas curriculares contempladas nesse contexto são democráticas na medida em que respeitam as diferenças socioeconômicas de gênero, faixa etária, étnicas, culturais e das crianças com necessidades educacionais especiais; e que também garantam a elas o direito a terem acesso à cultura deixada pela humanidade, através de saberes que são repassados pelas gerações como forma inclusive de continuação da espécie humana. Esta garantia de direitos, contempladas pela Lei vigente envolvem a criança e a Família, no que tange ao 
direito a educação infantil. No campo teórico há divergências em torno da função que esta etapa da escolaridade deve cumprir, permitindo assim que as propostas pedagógicas se concretizem através de práticas educativas que primam pela liberdade de expressão, entendendo a aprendizagem como processo que independente do processo de ensino, são consolidados por práticas educativas que levam a eles o prazer de desenvolver aprendizagens que vão se consolidar através de diferentes saberes. Essas práticas e experiências que foram desenvolvidas e ainda continuam sendo, são realizadas desde um tempo em que ainda não havia a percepção de que eram inovadoras no âmbito educacional. Os primeiros passos dados nesse contexto envolveram diferentes atores, diferentes momentos, diferentes lugares...

No Colégio Municipal Doutor Aurelino G. Barbosa, as práticas pedagógicas desenvolvidas visam a dinamização de um trabalho que dá a esses alunos essa liberdade de expressão mencionada na BNCC. A BNCC é citada aqui, pois seu contexto vai de encontro às práticas desenvolvidas por nós professores das escolas envolvidas nessa pesquisa. Estas são práticas capazes de fazê-los participar de atividades culturais como danças, músicas, peças teatrais e outros trabalhos com o intuito de desenvolver as suas habilidades pessoais, performáticas e motoras para uma aprendizagem mais efetiva.

Segundo a BNCC (2014, p. 51), da qual participamos enquanto professores no seu processo de construção fazendo sugestões por escrito, seria importante incentivar no bojo desse documento que houvesse uma transição entre as duas etapas da Educação Básica para que houvesse equilíbrio entre as mudanças introduzidas, para garantir a integração e a continuidade dos processos de aprendizagens desses alunos, respeitando-se assim as singularidades e as diferentes relações que esses alunos estabelecem com o conhecimento, garantindo também a natureza das mediações de cada etapa. Estabelecendo estratégias de acolhimento e adaptação tanto para os alunos quanto para os docentes, de modo que a nova etapa se construísse com base no que o aluno sabe e é capaz de fazer, em que constituem uma perspectiva de continuidade de seu percurso educativo. No contexto das escolas que constituem o objeto desse estudo, os alunos são estimulados de diferentes formas para uma aprendizagem mais efetiva e 
diferenciada. Deste modo, alcançam as séries mais elevada. São capazes de desenvolver trabalhos com mais autoconfiança e autoestima.

Já o aprendizado de Jovens e Adultos vive atualmente mudanças em uma perspectiva de renovação de seu sistema de ensino que nos leva enquanto educadores a entender como afirma Paulo Freire (1979) que:

"Uma alfabetização não pode ser feita de cima para baixo, nem de fora para dentro, como uma doação ou uma exposição, mas de dentro para fora pelo próprio analfabeto, somente ajustado pelo educador. Esta é a razão pela qual se vive a procura de um método que seja capaz de fazer instrumento não só do educador, mas também do educando”.

Paulo Freire (1979) em suas escritas nos leva enquanto educadores a compreender em que momento ele começou a desenvolver seu trabalho de alfabetização, que se fundamentava em métodos e objetivos que buscavam adequar o trabalho à especificidade dos alunos. Cada aluno traz consigo uma aprendizagem que vem do seu meio social. Como se pode perceber, esse trabalho teve inicio com a conscientização de que alfabetizar adultos requeria o desenvolvimento de um trabalho diferente daquele destinado à criança, pois as necessidades e possibilidades daqueles educandos exigiam o desenvolvimento de propostas adequadas a elas. O contexto político muitas vezes foi quebrado pelo paradigma da amizade entre todos os envolvidos: escola, políticos, comunidade e todos do entorno da escola. E foi assim que surgiu elaborada por nós professores das escolas em foco a dinamização curricular dos trabalhos desenvolvidos.

Na concepção de PIMENTA (2002, p. 86) o processo de democratização da educação brasileira, e a sua qualidade leva a um entendimento maior do que vem a ser a escola noturna, e que papel ela ainda ocupa na evolução do acesso da sociedade periférica com essa modalidade de ensino. Para os que trabalham durante o dia e necessitam da qualidade dessa escola noturna, que é frequentada na maioria das vezes por adolescentes (com distorção idade e série), senhores e senhoras com idade avançada que retornam a escola por não terem tido a oportunidade no tempo certo de concluírem seus estudos; e que trabalham para se sustentar e prover o sustento de sua família, conciliando assim a necessidade de equalizar duas vertentes bem controversas do ensino noturno: sobrevivência e os estudos. 
No entorno do Colégio Municipal Doutor Aurelino G. Barbosa, é gritante esse fato. Muitos de nossos alunos vivem em uma situação muito difícil, pois eles dependem da roça para sobreviver. Quando essa roça com suas plantações é atingida por pragas, a maioria deles precisa da escola para matar a fome. As famílias são grandes, e as dificuldades são muitas. Há alunos que caminham para chegar à escola por duas horas ou mais. O que os mantém focados nos estudos, são as formas que cada um dos educadores que os atendem oferecem no espaço escolar. O grau de amizade que se estabelece ali, é que faz com que eles desejem continuar e concluir esses estudos para terem uma melhor perspectiva de vida, e para que possam de alguma forma concorrer ao mercado de trabalho com mais oportunidades. Esses alunos retornam a escola em busca de orientação para fazerem concursos, processos seletivos... O município de Piraí ainda oferece oportunidades para esses alunos investindo nas inovações que se tornaram consagradas no espaço escolar, como arcabouço para novas aprendizagens e novos conhecimentos. Eles têm oportunidades de melhorar as suas vidas através do incentivo da prefeitura de Piraí. Esse incentivo ocorre na maioria das vezes através de projetos, que é essencial para que haja uma efetivação dessas demandas de eventos. A secretária Sandra Gomes Simões, que durante esses 19 anos está a frente da Secretaria de Educação do Município de Piraí, é uma pessoa aberta à conversação e a inovações. Essa escola hoje, que atendia no passado apenas o Ensino Fundamental, primeiro e segundo segmentos, tornou-se uma escola diversificada. Mesmo não sendo competência do Município, e vendo a dificuldade dos alunos de se deslocarem para outros municípios em busca de dar continuidade a seus estudos, esse se mobilizou no ano de 2004, com ajuda dos diretores, professores, comunidade, prefeito e vereadores em consulta pública, conseguiu junto ao governo Estadual e Federal - a ampliação do Ensino nessa localidade chamada ‘Cacaria’ que hoje atende desde a Educação Infantil até o Ensino Médio, com professores hoje a maioria Mestres e Doutores; pois há um investimento na ampliação e capacitação dos mesmos para o crescimento do nível de escolaridade desses e melhoria na qualidade de ensino do C. M. Doutor Aurelino G. Barbosa. O Município de Piraí hoje é uma das referências em matéria de Educação no Rio de Janeiro, esse fato pode ser constatado pela mídia local, e pelas publicações em jornais de grande circulação no Estado do Rio de Janeiro e através de mídias 
eletrônicas. Isso é comprovado também pelo IDEB - Índice de Desenvolvimento da Educação Brasileira.

Com a ampliação de novos horizontes para a educação através da aplicação de novas políticas públicas difundida pelo Governo Federal através dos anos, e projetos pedagógicos desenvolvidos no espaço escolar; passou a haver uma necessidade de mudança na política que orientasse o funcionamento desse tipo de educação, que atendia na maioria das vezes a classe trabalhadora mais pobre e periférica, e depois de um tempo passou a atender também alunos que estiveram fora da escola por muitos anos, aqueles que ficam retidos no ensino diurno e tem problema com a distorção idade série.

Abrir as portas da escola noturna para quebrar o paradigma da exclusão, foi uma das formas que os sistemas estaduais de ensino, juntamente com o sistema municipal encontraram para atender uma demanda de inclusão, e responder de forma positiva às pressões sociais, transformando essa modalidade de ensino em um grande investimento. Os institutos de Educação Federal ainda não alcançaram esse viés, mas espera-se que um dia eles cheguem a esse entendimento.

Partindo dessa situação, houve uma necessidade de democratização da escola pública, e de qualificação do ensino básico. Procura-se a partir daí para a escola noturna, um lugar por excelência onde jovens trabalhadores buscam não só a qualificação para o trabalho, mas também o acesso a uma ocupação melhor e digna, dando a eles capacidade para melhor se sustentar, se socializar e trocar experiências que ultrapassassem os muros da escola.

Educadores e especialistas em educação como Freire, a BNCC, Pimenta, Alan da Rosa e outros afirmam que qualquer diretriz que buscasse a democratização da escola pública, deveria resgatar a discussão políticopedagógico de qualificação do ensino noturno na direção de um novo projeto de estudo, que desse suporte para que essa educação desse significado a alguns programas de educação básica para jovens e adultos para que esses não fossem banalizados em suas finalidades primordiais, como arcabouço para dar ao ensino fundamental um modelo próprio para embasar os cursos noturnos, construindo a partir daí uma forma de viabilização de uma avaliação mais concreta, sistemática e objetiva para uma prática que contemplasse uma aprendizagem representativa para os seus principais atores: os gestores, os professores, os alunos e os 
funcionários. As discussões que envolvem as questões das dimensões relativas à qualidade do ensino não se esgotam no plano pedagógico, elas extrapolam os muros da escola, envolvendo aspectos políticos, econômicos e sociais. No arcabouço do sistema educacional, busca-se uma cultura diversificada para uma classe social que é marginalizada pela situação econômica em que vive.

Sendo assim, enquanto professora defendo aqui esse relato que faz parte do universo escolar que envolve essas modalidades de ensino a "Educação de Jovens e Adultos” em parceria com a Educação Infantil, o Ensino Fundamental e o Ensino Médio; onde envolve uma relação de amizade interventora que traz em seu contexto a percepção de que "a cultura da periferia sempre existiu, mas não tinha oportunidade de ter sua voz, suas especificidades e seus princípios”. Desenvolvemos, nas escolas que são objeto dessas práticas, a integração social e cultural através da promoção de eventos conduzidos como propostas e experiências pedagógicas que envolvem a cultura da periferia, a cultura afrobrasileira, dando margem para que esses eventos realizados venham ajudar no desenvolvimento de pesquisas históricas que englobam o conhecimento da cultura da periferia e de suas raízes. Mesmo essas escolas sendo consideradas escolas de áreas periféricas, a atuação da comunidade é bem diferente da atuação das escolas de periferia urbana que convivem em área de risco. Essas escolas estão inseridas em áreas periféricas, na área Rural. Gradativamente, vem ocorrendo mudanças nessa clientela, pois está ocorrendo um recuo muito grande de muitos moradores de comunidades de risco, para esses locais. Entretanto, mesmo assim ainda se consegue manter a ordem e a disciplina nessas escolas.

Os passeios culturais são apresentados aqui como "uma janela para o mundo”, pois esses alunos são levados a lugares que ajudam a fomentar e enriquecer esse currículo tão difundido em busca de novas perspectivas a serem desenvolvidas e aplicadas como métodos de escritas e leituras. Dessa forma, os alunos conseguem expandir sua visão de mundo através do conhecimento de novos espaços. A maioria nunca haviam tido a oportunidade de conhecer outros espaços pelas dificuldades financeiras apresentadas por suas famílias e por residirem, por vezes, em lugares isolados que para chegar até a escola precisam caminhar horas a fio. 
Ao falar das diferentes práticas que podem ser aplicadas em diferentes espaços pedagógicos, pode-se observar que há espaços escolares que procuram fazer dessas práticas, adaptações curriculares em busca de uma "Escola Viva", escola essa que faz com que os sujeitos que a ela pertencem se sintam vivos e dinâmicos, podendo assim trabalhar a prática como uma vertente para a aprendizagem em busca de um conhecimento significativo para a sua vida. Enquanto professora e educadora, pude perceber esse trabalho ocorrendo em várias escolas as quais trabalhei. Sendo assim, os relatos desses fatos partem do espaço de duas escolas em diferentes situações e em diferentes municípios.

Os trabalhos que estão descritos e apresentados através de fotos das práticas educativas fazem parte de diferentes atuações que vão ao encontro de práticas que são brilhantes que já foram objeto de estudos acadêmicos em diferentes livros e em diferentes autores; mesmo sendo desenvolvidas em espaços diferentes, estas tinham a mesma autonomia, e promoviam a inserção dos alunos ao mundo da leitura oral e escrita, promovendo também uma leitura de mundo mais dinâmica e concreta, na busca pelo conhecimento. Esse fato poderá ser constatado através das diferentes releituras feitas por eles em suas apresentações.

Essas práticas que estão aqui apresentadas foram desenvolvidas em parceria com diferentes educadores, diretores, coordenadores, orientadores com o auxílio dos profissionais da educação, tendo como sujeitos principais para a execução desses, os alunos das escolas citadas. Cada ação, cada evento trouxe consigo um aprimoramento em muitas atividades no espaço escolar que podem ser observados e analisados através de fotos e relatos.

Reconstruir a história e as memórias coletivas e individuais da Educação de Jovens e Adultos, com a parceria da Educação Infantil, Ensino Fundamental e Ensino Médio das escolas municipais Panaro Figueira e do Colégio Municipal Doutor Aurelino Gonçalves Barbosa que ocorreram entre os anos 2000 e 2018, é o arcabouço principal dessa pesquisa, pois elas foram registradas através de fotos recolhidas e guardadas durante anos em acervo particular; e analisar essas memórias individuais e coletivas vividas no espaço educacional através de novas leituras e releituras de práticas educacionais promovidas na intenção de atingir o ideário de aprendizagem de cada aluno é que nos trouxe até aqui. Uma situação comum nesse meio, é que grande parte dos alunos, durante o dia trabalham na roça, no asfalto, em atividades que exigem deles um desgaste muito grande. 
Frequentemente eles chegam a escola já cansados ou, nem mesmo conseguem chegar a ir a escola. Por isso o índice de evasão era muito alta, e dessa forma passamos a trabalhar para mudar essa situação. Há um projeto no qual professores, orientadores, funcionários, diretores visitam as casas desses alunos para descobrir o porquê do abandono da escola. Esses alunos na maioria das vezes não tem outra perspectiva de mudança de vida, a não ser através da educação que a escola pode oferecer-lhes, e com isso a escola ocupa um papel crucial para essa mudança, tornando-se uma janela para o mundo. Esse fato pode ser percebido por nós educadores pois, lecionamos a muito tempo nessas comunidades e criamos laços de amizade.

Dessa forma, remontar a história e as memórias desse alunos e das comunidades envolvidas no contexto escolar, envolvendo-os como espectadores, autores e coautores dos trabalhos desenvolvidos como experiências e práticas pedagógicas para a Educação de Jovens e Adultos, com a parceria da Educação Infantil, Ensino Fundamental e Ensino Médio, é uma diretriz que se pauta a partir do Projeto Político Pedagógico (PPP) da escola; aplicados em busca de uma escola que permeia novos horizontes em educação. Vai haver momentos em que as memórias se misturarão com as histórias, mas esse é um fato comum a qualquer historiador, pois às vezes as memórias nos falham... Mas as fotos a reavivarão.

Analisar os resultados da produção de narrativas literárias, peças teatrais, sarau de poesias e gincanas construídas pelos próprios alunos, com a parceria e envolvimento dos professores; tendo em vista os objetivos perseguidos por diferentes ações pedagógicas articuladas num projeto interdisciplinar, é o que se pretende alcançar com os relatos dessas experiências.

A pretensão aqui é realizar um diálogo com os livros de Paulo Freire; o Livro de Alam da Rosa "Pedagoginga, Autonomia e Mocambagem”, que apresenta práticas pedagógicas voltadas para a Educação de Jovens e Adultos; práticas nas quais Alan da Rosa atuou em busca da inserção de pobres, negros e moradores de áreas periféricas, desenvolvendo esse projeto em lugares improvisados em grandes centros urbanos, mas que tinham praticamente o mesmo cunho de práticas aplicadas em escolas noturnas tradicionais. O livro de Alan da Rosa é um livro de relatos e reflexões sobre uma prática de três anos em Educação Popular, de 2009 a 2012. 
Não se pode deixar de fora aqui em nenhum momento, diferentes autores que em suas obras falam de diferentes práticas pedagógicas desenvolvidas em diferentes espaços e em diferentes modalidades de ensino. É claro, que a parte teórica que envolve o passo a passo desses relatos, trazem consigo o aparato bibliográfico que constrói toda a parte narrativa das 'imagens, fotos e memórias' que embasam esses relatos e a eles se direcionam.

Como se pode perceber através do embasamento desses relatos, a Educação de Jovens e Adultos é uma modalidade de ensino que tem como clientela diferentes tipos de alunos: alunos que estão inseridos na distorção idade série - alunos que anos e anos ficaram fora da escola e que por alguma razão voltaram em busca de diplomas e aperfeiçoamento do saber - alunos que também às vezes se veem forçados a abandonar o espaço escolar por seus horários de trabalho não permitirem a eles acompanharem as aulas - jovens que estão fora da faixa etária de suas turmas durante o ensino diurno, e ficam atrasados nos estudos por diferentes fatores, com isso se veem compelidos a estudarem no ensino noturno pelo fato da distorção idade/série, pois os deixaram fora de perspectiva no ensino diurno.

A maioria dos trabalhos desenvolvidos com essa clientela visa fazê-los conhecer a sua cultura, o processo de formação do povo brasileiro através das histórias literárias, passeios culturais, pesquisas e montagem de 'Feiras Culturais e Folclóricas', compreendendo assim a influência da miscigenação do nosso povo pela colonização dentre as obras literárias, e a influência de suas culturas nas comunidades periféricas, analisando suas histórias; e reconhecendo as suas memórias e tradição cultural advindas da sua base social.

A intenção aqui é de estabelecer um parâmetro entre diferentes autores e as suas respectivas abordagens nos moldes do tema proposto no campo da Literatura e da Educação envolvendo ações diversificadas em busca de novas perspectivas educacionais e de uma educação mais igualitária.

Pelo nível de pesquisa já realizado até a atualidade, percebe-se que ainda há muitos dados a serem pesquisados prontos para serem tidos como modelos de análise para as questões levantadas aqui, mas mesmo assim procurar-se-á verificar o nível em que se encontra os estudos realizados, e quais os fatores primordiais que estão sendo utilizados hoje para conhecê-los e analisá-los. 
O estudo em tela é de natureza qualitativa, com abordagem descritiva, que utiliza como técnica de pesquisa a revisão bibliográfica de alguns autores que já foram citados anteriormente, e relatos próprios de memórias individuais e coletivas; tendo seus objetivos definidos de maneira exploratória, através de artigos científicos, livros impressos, livros digitais e revistas científicas. Esta pesquisa também está utilizando o apoio teórico de artigos, dissertações de mestrado e teses de doutorado que fazem parte do acervo da PUC-RIO e da CAPES.

Justifica-se aqui essa linha de pesquisa por entender-se que as histórias, se entrecruzam e se perpetuam através de seu marco histórico. A presente Dissertação de Mestrado consiste em reunir e socializar experiências bem sucedidas no ensino de Língua Portuguesa desenvolvido em trabalhos interdisciplinares, que tiveram como mediação experiências e práticas pedagógicas que aproxima cada vez mais alunos, professores, profissionais da educação e a comunidade escolar através de uma dinâmica educativa que engloba todos os envolvidos nesse processo, para além dos muros da escola em busca de conhecimento para a vida.

A escolha do tema pautou-se na intenção de estimular práticas pedagógicas que sensibilizem uma integração nas ações desenvolvidas no ambiente escolar, numa perspectiva de mudança na integração, na participação, na gestão, pelo corpo docente, discente e pelos profissionais da educação das escolas que são objeto da criação dessas memórias através de imagens, fotos, textos, paródias, poesias, contos e outros tipos de instrumentos que estão fomentando a história e as memórias construídas.

As propostas pedagógicas desenvolvidas fazem parte da criação de registros de memórias e de histórias coletivas e individuais, na intenção de estimular a integração da escola com a comunidade, família e profissionais de educação envolvidos no processo ensino-aprendizagem, utilizando como palco para sua disseminação o Curso de Pós Graduação em nível de Mestrado em 'Literatura, Cultura e Contemporaneidade’.

A tendência atual na educação brasileira procura integrar os aspectos formais e materiais do ensino com os direcionados às transformações sociais. Valoriza a escola enquanto mediadora entre o aluno e a cultura desempenhando 
seu papel pela transmissão e assimilação dos conhecimentos inseridos na prática social.

Essas práticas têm a intenção de demonstrar os benefícios da integração docente e discente no espaço escolar com o auxílio do PPP - Projeto Político Pedagógico do C. M. Dr. Aurelino G. Barbosa que traz como diretriz as normas de convivência que primam pela valorização do ser humano, e pautam seus objetivos na crença de que as dificuldades e os conflitos que venham a ocorrer no espaço escolar serão superados na medida em que acreditarmos no potencial do ser humano, enquanto condutor do seu saber; e no poder da Educação enquanto promotora desses saberes. Dessa forma, o tratamento dispensado à comunidade escolar (alunos, pais, professores e funcionários) é aquele que pressupõe a interrelação de amizade, o diálogo como meta e a compreensão como finalidade; através de técnicas mediadoras. Esses princípios surgiram a partir do reconhecimento das diferenças entre os indivíduos, tornando-se fruto do processo de socialização e desenvolvimento individual e coletivo dos seus educandos. Dessa forma, a Instituição Escolar potencializa as capacidades pessoais, ajustando a sua maneira de conduzir o processo educativo.

Essas diretrizes almejadas e idealizadas abriram espaço para novas propostas pedagógicas envolvendo trabalhos em grupos utilizando jogos, brincadeiras peças de teatro criadas pelos próprios alunos ou adaptadas de outros espaços com o auxílio dos educadores, que fazem parte do corpo escolar. As ações desenvolvidas potencializam apresentação de danças, músicas, interpretação de poesias através da música, paródias e outras produções que envolvam família e comunidade em busca de memórias individuais e coletivas apresentadas através de fotos e imagens cristalizadas através do tempo; fotos e gravações sejam digitais ou não, procurando reconhecer os papéis diferenciados de todos que fazem parte da história e das memórias educativas criadas e reproduzidas por essas imagens e fotos dos trabalhos desses alunos no intuito de criar uma perspectiva mais universal na intenção de ampliar o conhecimento científico, cultural e coletivo com o auxílio da reconstrução das experiências do outro; através de memórias criadas por imagens num processo de releitura dos eventos vividos através das imagens que estão apresentadas e interpretadas aqui. As diferentes literaturas mostram que a família transmite valores e crenças e, como 
consequência, os processos de aprendizagem e desenvolvimento se estabelecem de uma maneira coordenada; esse fato ocorre quando realmente essa família se encontra presente no desenvolvimento da aprendizagem.

O trabalho escolar é uma ação de caráter coletivo, por isso a construção de diferentes momentos de aprendizagens através da montagem de oficinas de textos, paródias, peças a serem apresentadas tanto no espaço escolar, quanto para além desse espaço em Feiras Culturais, FESTEJAS (festas produzidas com a participação de alunos da EJA), Festivais de Paródias (paródias construídas em conjunto pelos alunos em sala de aula, em um trabalho direcionado pelo professor de Língua Portuguesa) com montagem de dança e apresentação dos alunos desenvolvidos com a participação dos professores de Artes e Educação Física em uma participação conjunta, e integrada dos membros de todos os segmentos da unidade escolar e da comunidade escolar.

A implementação de planos de ação que permeiam o espaço escolar, na intenção de melhorar a integração de todos que fazem parte do entorno das escolas objetos da pesquisa estão sendo objeto da criação dessas memórias individuais e coletivas, no intuito de transformar o espaço escolar em um espaço mais atrativo e pulsante no contexto educacional, tornando-se assim imprescindível para o sucesso da escola como um todo.

Dessa forma, cabe aqui ressaltar que se construíram ações pedagógicas envolvendo a disciplina de Língua Portuguesa em um trabalho interdisciplinar dentro do espaço escolar na intenção de promover um trabalho comprometido com a formação do cidadão; com isso, alguns dos aspectos devem se tornar relevantes.

Segundo DEMO (2003), a pesquisa qualitativa é considerada uma dinâmica entre o mundo real e o sujeito, possuindo um vínculo indissociável entre o mundo objetivo e a subjetividade, não podendo ser descrita em números. Os fenômenos são interpretados e atribuídos de forma básica na construção da pesquisa qualitativa, sendo o pesquisador o instrumento chave da pesquisa e o ambiente natural à fonte precursora para coleta de dados com base em relatos que fundamentam os escritos apresentados. 


\section{Historiografia}

\section{1}

\section{Práticas que renovam os caminhos da leitura e da escrita}

Partindo das premissas feitas pelos autores pesquisados, entende-se que uma pesquisa que envolva Práticas Pedagógicas em busca da ampliação dos horizontes da leitura e da escrita precisa relacionar os eixos teóricos que partem aqui dos autores citados devem ser apurados e aprimorados ao longo do desenvolvimento destes, sendo eles: um primeiro de natureza historiográfica; outro que diz respeito à crítica literária e um terceiro que desenvolve a relação direta entre Linguagem e Literatura. Vale ressaltar que há várias interseções entre o que se chama de eixo teórico, e a prática em si como condutora e transformadora de novas realidades e novas perspectivas de vida a partir das iniciativas e das diferentes práticas de leitura e de aprendizagem aplicadas em busca de novos horizontes para a Educação.

O enfoque principal desta pesquisa são as Práticas Educativas aplicadas na Educação de Jovens e Adultos em uma parceria com a Educação Infantil, Ensino Fundamental I e II, e Ensino Médio envolvendo toda a comunidade escolar. A Educação Noturna, hoje depois de várias Nomenclaturas aplicadas através dos anos tem a significância de ser chamada 'Educação de Jovens e Adultos (EJA)', que passou a ser usado a partir de 1997 na I CONFITEA em Hamburgo Alemanha, quando se percebeu no mundo todo o grande número de jovens presentes em turmas de “Educação de Adultos” como era chamada até então, ou seja:

O conjunto de processos de aprendizagens formais, graças aos quais as pessoas, cujo entorno social consideram adultos, desenvolvem suas capacidades, enriquecem seus conhecimentos e melhoram suas competências técnicas ou profissionais ou as reorientam a fim de entender suas próprias necessidades e as sociedades. A educação de adultos compreende a educação formal e permanente, a educação não formal e toda a gama de oportunidades de educação informal e ocasional existente em uma sociedade educativa e multicultural, na qual se reconhecem os enfoques teóricos baseados na prática. (FREIRE 1979/2002) 
Hoje a escola noturna não recebe apenas adultos como se pode perceber, pois ela traz para o espaço escolar diferentes atores sendo eles tanto jovens quanto adultos que por algum motivo foram obrigados a frequentarem a escola noturna. No Colégio Municipal Dr. Aurelino G. Barbosa por ser uma escola municipal que se diferencia por receber todos do entorno da escola que querem estudar, que vai desde a Educação Infantil ao Ensino Médio (que não é competência municipal por Lei). Já a Escola Municipal Panaro Figueira, por ser uma escola de referência no município de Seropédica, recebe na escola noturna uma quantidade elevada de alunos, as turmas são imensas, mais ainda se consegue fazer um trabalho de excelência pela clientela que se recebe. As Práticas Educativas aplicadas ali são um tanto diferentes das Escolas de Piraí, mas mesmo assim ainda se consegue realizar um bom trabalho devido ao comprometimento do Diretor Mário Lorefice, que conduz há muitos anos a direção dessa escola, e com isso ainda mantém a continuidade das práticas desenvolvidas ali.

Para se falar de Metodologia, e sua aplicabilidade na Educação; pode-se citar Minayo (2003), que ao dar significado ao termo metodologia, nos leva a compreender que o caminho do pensar e a prática exercida na abordagem da realidade vivenciada por alunos, professores, profissionais da educação, e comunidades escolar, incluindo-se simultaneamente os instrumentos de operacionalização do conhecimento da criatividade e a teoria da abordagem do pesquisador, é um fator primordial para se compreender a importância das diferentes aprendizagens em busca do conhecimento que ocorrem no espaço escolar.

Segundo Pimenta (2004, p. 85), o vínculo estreito entre educação, democracia e qualidade do ensino deve partir de uma participação mais ativa e crítica da vida social e política de um indivíduo em conformidade com a escola nas práticas sociais democráticas que lhes possibilitam entender e interpretar toda a gama de valores e informações que lhe são transmitidas no cotidiano. Nas escolas que são objetos desse estudo, os alunos usam o espaço escolar como “espaço de lazer”, considerado por eles e suas famílias um espaço ainda seguro como meio de socialização. Só se pode viver democraticamente quando se é respeitado nos seus direitos. Direitos estes que não se restringem ao acesso à 
escola de qualidade, envolvem também a tomada de consciência de tantos outros e, consequentemente de luta para conquistá-los.

Pode-se concordar com Demo (1986) quando nos diz que “a relação entre a educação e a democracia não é mecânica e automática, pois a democracia depende fundamentalmente de seu ator insubstituível: o cidadão organizado. E para a formação desse cidadão organizado, a educação significa uma ferramenta importante".

Segundo Demo (1986), para que se possa fazer da educação uma ferramenta importante para o processo de democratização da sociedade, torna-se necessário que a escola pública se torne um espaço relevante de aprendizagem onde se possa viver e construir cidadania.

A pretensão aqui apresentada pretende contribuir para o conhecimento da realidade da escola noturna do Ensino Fundamental I e II, e Ensino Médio, que no Colégio M. Dr. Aurelino G. Barbosa é ministrado à noite, a partir de um dos seus atores - o aluno. É impossível que na luta cotidiana desses pequenos atores, na luta por um espaço de socialização, na busca do poder da escola como forma de sobrevivência, na conciliação entre escola e trabalho; essa escola possa ser gestada para uma nova identidade individual e coletiva. Acredita-se, também que ao se tentar decifrar as angústias desses atores, suas esperanças e seus sonhos, pode-se estar contribuindo para que esses jovens sejam portadores de uma nova utopia construtora de um novo projeto pedagógico para a escola brasileira.

As análises de Demo (1986) tentam recuperar a perspectiva do ator, seu ponto de vista, sua identidade. Pode-se observar que as ideias desse autor continuam tendo reflexo até hoje. Assim sendo, os estudos descritos por ele, continuam tendo ressonância, pois ele identifica novos sujeitos, penetrando em sua esfera no cotidiano; ampliando, portanto, as possibilidades de explicação das formas de organizações da ação e da mobilização nas sociedades contemporâneas, afastando-se dos paradigmas clássicos da sociologia marxista da luta de classes. Buscando assim construir uma nova teoria do social, dos processos que levam a produção e reprodução da sociedade. Hoje se percebe que a sociedade contemporânea esta caminhando novamente para a alienação por meio de uma mídia manipuladora, que dita às regras de uma sociedade que nos últimos pleitos eleitorais mostrou que a sociedade capitalista não aceita o desenvolvimento 
daqueles que lhes serviram a vida inteira, sendo considerados subalternos, sem direitos de ir e vir, sem direitos trabalhistas e sem direito a uma Educação de Qualidade...

Muitos professores que integram o programa de educação de jovens e adultos têm ou já tiveram experiências com o ensino regular e infantil; baseados nestas experiências colocam questões a respeito dos métodos e conteúdos da educação infantil e do ensino regular que servem também para os jovens e adultos que estão no ensino noturno, desta forma apresenta também as especificidades dessa faixa etária. Em busca da resposta a essas indagações e aos desafios apresentados por seus alunos; tentam fazer adaptações curriculares, mudanças de postura, de estratégias e de conteúdos.

Um princípio pedagógico bastante assimilado que é uma herança da Educação Popular nos anos de 1960 entre os que se dedicam à educação básica de jovens e adultos é o da incorporação da cultura e da realidade vivencial dos educandos como conteúdos ou ponto de partida da prática educativa. No caso da educação de jovens e adultos, talvez fique mais evidente a inadequação de uma educação que não interfira nas formas de o educando compreender e atuar no mundo. A análise das práticas, entretanto, mostra em alguns momentos as dificuldades de se operacionalizar esse princípio, por fatores que às vezes fogem ao controle de quem se insere nesse contexto.

\section{2}

Fotografias, memórias e histórias

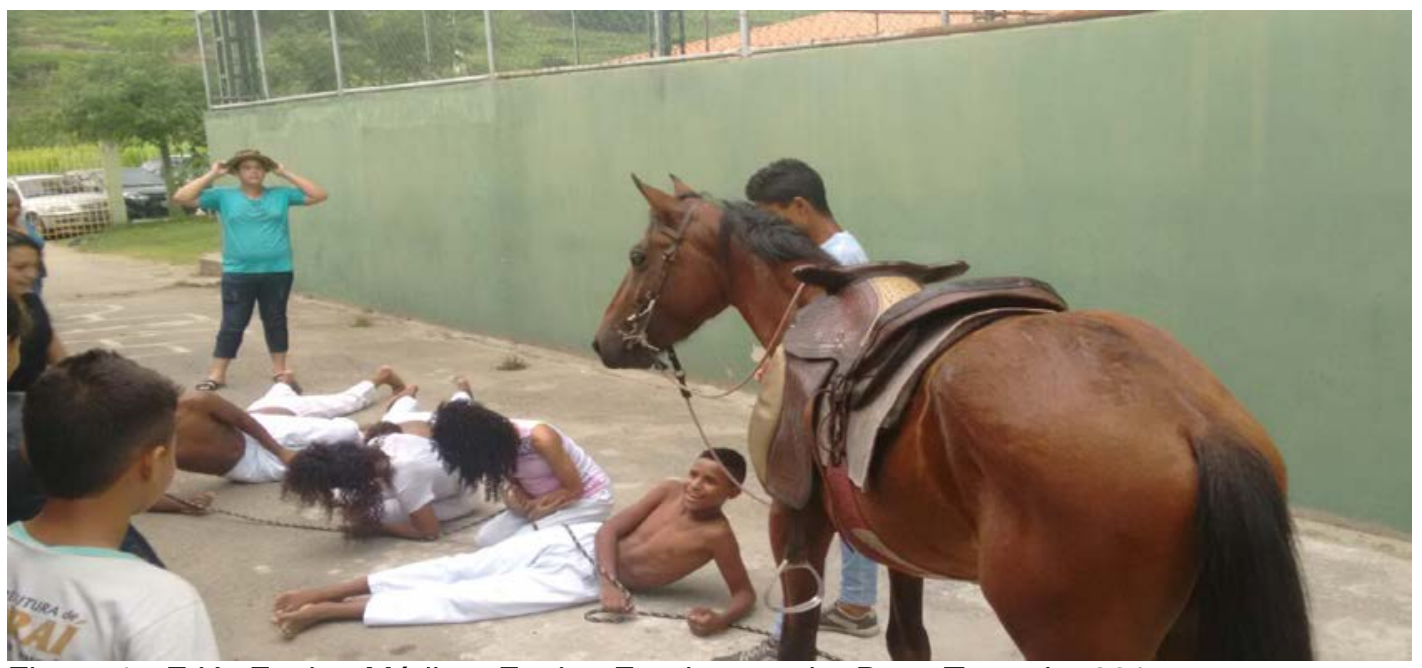

Figura 1 - EJA, Ensino Médio e Ensino Fundamental - Peça Teatral - 2017. 
As Peças Teatrais apresentadas pelos alunos sobre a escravidão, no espaço escolar trazem para o presente, representações de um passado que retrata as vivências da colonização do nosso país através da história. Essa é uma forma que se tem de se recriar como foi; e o que foi a escravidão no nosso país, em um dia que se elegeu para se comemorar as conquistas que foram feitas através dos tempos para essa consciência representativa do povo brasileiro, que foi feita em seu ápice maior através de uma miscigenação entre diferentes povos.

Essa representação teatral dos alunos do C. M. Doutor Aurelino G. Barbosa nos conduz ao tema voltado para a escravidão. Ao representarem esse tema, sem perceberem eles rompem com a ideia do preconceito de raça e econômica. A associação que se tem entre imagem de si e experiência prazerosa da representação é emancipatória para eles, pois eles demonstram isso após as apresentações através da análise e criação de mesas redondas onde eles apresentam seus pareceres a esse respeito. Essa representação relatada por eles os colocam fora desse tempo, a escola é o caminho para que essa situação não se repita, pois muitos deles desde novos trabalham no campo em situações que podese afirmar é desumana, pois na maioria das vezes trabalham roçando sem ter a oportunidade de reclamar do que fazem, pois precisam ajudar em suas casas. Temos alunos que usam a sua hora de lazer para se embriagar, pois a vida que levam não lhes agrada.

Há alunos que os pais trabalham em casa de família, e eles ao frequentarem essas casas de ricos como convidados, se veem distanciados de bens que se não estudarem talvez jamais terão condições de ter. O que se percebe ali, é que o que é belo para uma pessoa que tem uma vida abastada, é diferente do que é belo para uma pessoa desprovida de posses. Por isso afirmo aqui, que é legítima que nas margens da ciência histórica se desenvolva a filosofia da história, que nos leva a percorrer diferentes saberes em busca do conhecimento. Seria dessa forma desejável que ela não ignorasse a história dos historiadores, pois é essa história que dá base para os relatos e representações feitas no espaço escolar.

As memórias no espaço escolar que aqui se apresenta, são construídas através das imagens dos eventos, pois cada imagem evoca o desenrolar e a evolução dos eventos; permitem situá-los no espaço e no tempo; e nos trazem a lembrança daqueles que participaram e eram os atores que tinham a sua imagem 
reproduzida ali, e também nos leva a entender em que época o evento estava inserido.

A dualidade da história como história-realidade e história-estudo desta realidade explica segundo Le Goff às ambiguidades de algumas declarações de Lévi-Strauss sobre a história. Lévi-Strauss afirma que:

"Não saberia o que poderia ser chamado de ciência da história; pois para ele simplesmente a história seria algo que não poderíamos dispensar, precisamente porque essa história nos poria constantemente perante fenômenos irredutíveis". (LÉVI-STRAUSS apud LE GOFF, p. 16)

Com esse fato pode-se perceber que toda a ambiguidade que carrega a palavra 'história' pode estar contida nesta declaração. Marc Bloch propôs a definição de história como "a ciência dos homens no tempo", ele atribui a história como o objeto do estudo do homem, enquanto este se encontra integrado num grupo social, com isso ele pretendeu sublinhar uma característica marcante da história: o seu caráter humano, embora a investigação histórica englobe hoje alguns domínios da natureza. Os trabalhos desenvolvidos pelos alunos ajudam muito na formação de seu caráter enquanto ser humano, a parceria que ocorre entre os professores de diferentes disciplinas, ajudam na sua autoestima e auto confiança estabelecendo através dessas representações, uma formação de princípios, pois a partir delas se pode perceber que eles encontram o caminho desejado para sua formação mais efetiva para a vida. Isso posso afirmar enquanto educadora por experiência

Missac (1998, p. 109), ao escrever sobre Walter Benjamin, e o seu livro "Passagens", afirma que "Em todas as coisas, devemos procurar fazer do tempo nosso aliado". Ao falar de um fragmento de 'Parque Central', ele atribui a Baudelaire uma impaciência, que suscita o desejo de interromper o curso do tempo. Para Missac não se trata de se adaptar ao tempo, muito menos de dominálo, mas sim de buscar entre outras coisas uma indicação significativa que mostre a estreita ligação que existe nele entre a percepção do espaço e do tempo, ambas eminentemente ambíguas no mundo contemporâneo.

Pode-se observar nas fotos, nas imagens gravadas dos trabalhos desenvolvidos que a perpetuação do tempo, se faz com riqueza de detalhes na atualidade de forma diferente, pois foi pela criação do homem de novas mídias, novas tecnologias; que a partir de um determinado período do tempo, que as fotos 
passaram a perpetuar esse tempo, pois congelam em si um tempo que jamais poderá ser revisto, mas pode somente se perpetuar através da imagem registrada através de uma câmera fotográfica que retrata e perpetua o momento registrado proporcionando as lembranças através das memórias... Observem-se assim as imagens mostradas e descritas abaixo...

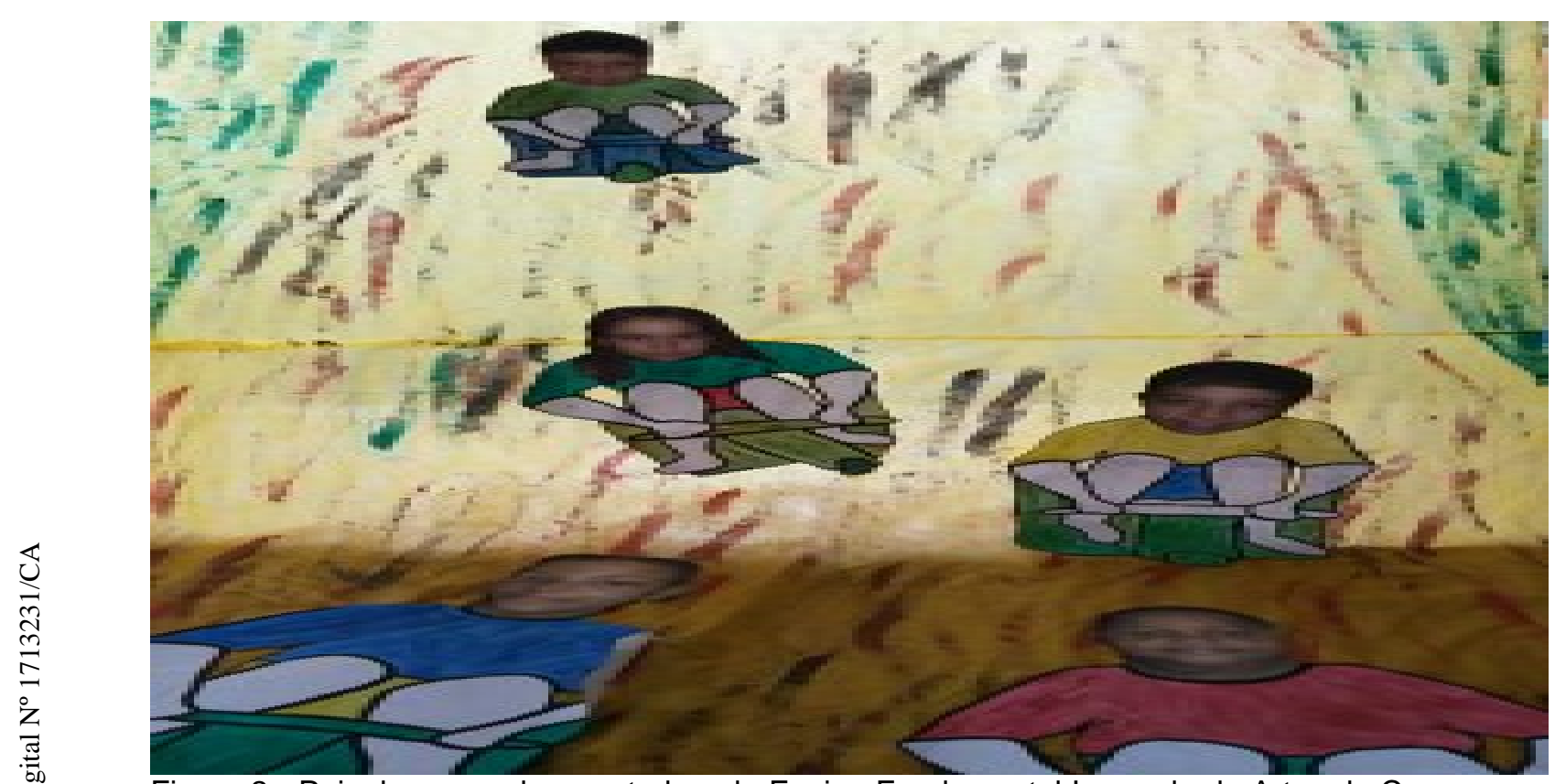

Figura 2 - Painel em guache montado pelo Ensino Fundamental I na aula de Artes do C. M. Dr. Aurelino G. Barbosa - Piraí.

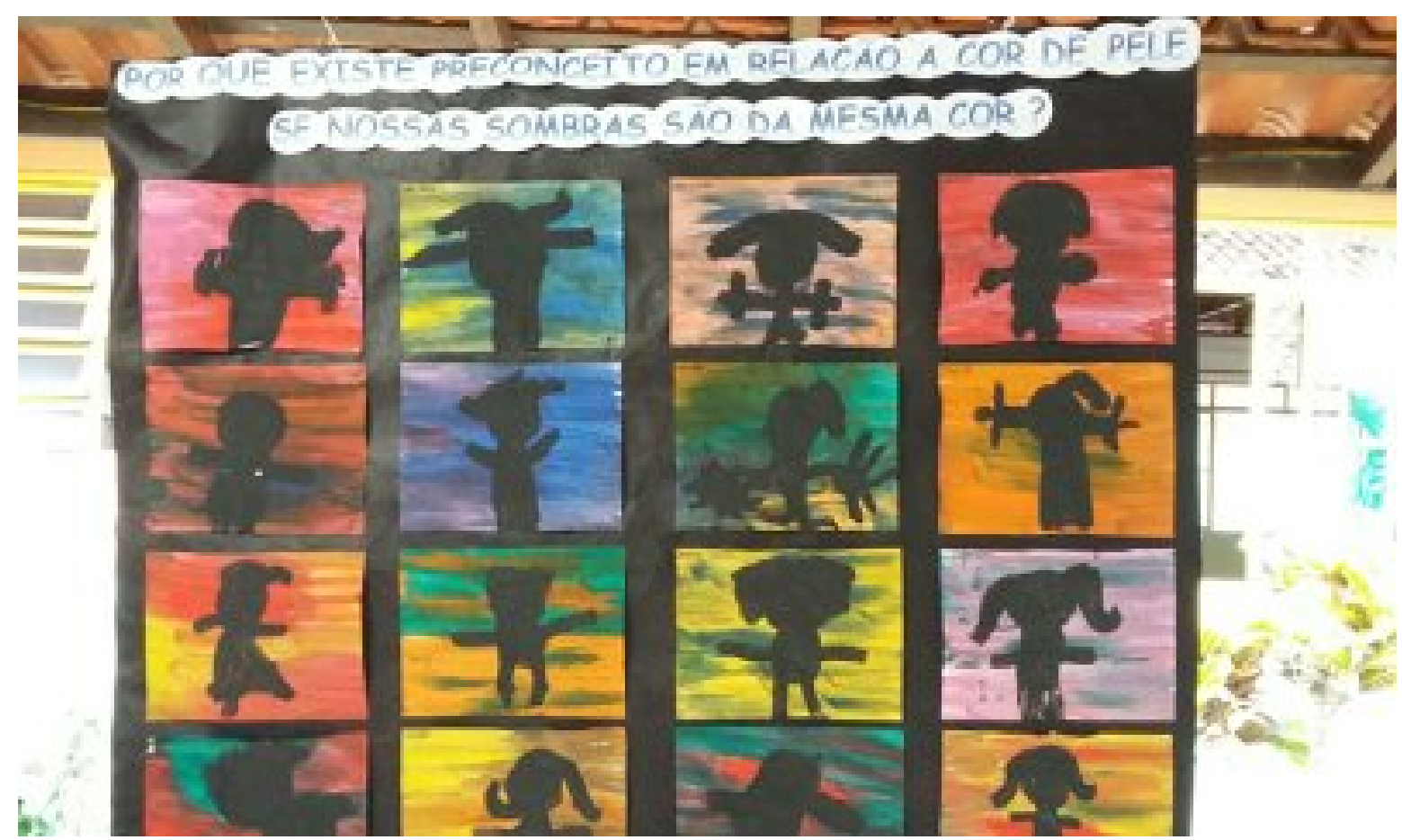

Figura 3 - Pintura com guache feita pelos alunos do Ensino Fundamental I do C. M. Dr. Aurelino G. Barbosa - Piraí. 


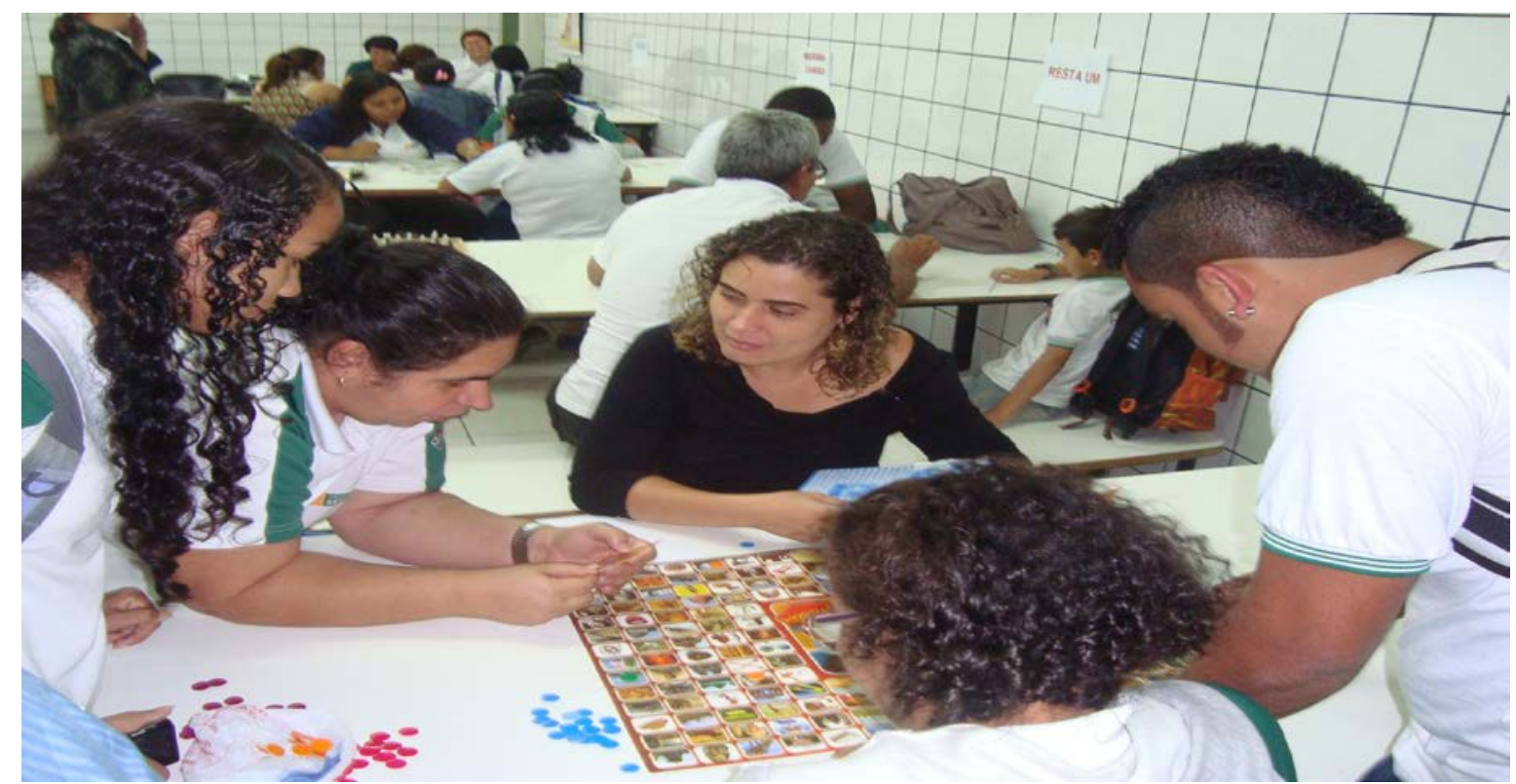

Figura 4 - Turmas da EJA da Escola Municipal Panaro Figueira com a professora de geografia Fernanda montando as pinturas em guache que seriam utilizadas na feira cultural.

Essas imagens nos levam a diferentes momentos de duas escolas, em contextos bem diferentes... Um dos trabalhos desenvolvidos foi elaborado por alunos do Ensino Fundamental I do C. M. Doutor Aurelino G. Barbosa que traz na imagem figura 3 os dizeres "Porque existe preconceito com relação à cor de pele se nossas sombras são da mesma cor?”; e a outra imagem figura 4 foi feita por alunos da Educação de Jovens e Adultos - EJA da E. M. Panaro Figueira com o auxílio da professora Fernanda de Geografia. A efetivação de um trabalho de pintura com a participação de um professor torna-se possível a partir do entrosamento entre os alunos de diferentes segmentos tanto no Ensino Fundamental I e II, quanto na Educação de Jovens e Adultos; todo esse processo criativo é pautado nas especificidades de cada um desses alunos em seu processo de produção, criação e de aprendizagem. Tornando essa forma de fazer Arte de uma maneira coletiva, profundamente importante para a criação de diferentes aprendizagens.

São essas situações criadas através de desenhos, pinturas e imagens, que se pode perceber que quando o aluno se encontra envolvido no mundo das artes, esse desenvolve habilidades que os levam a conhecer o mundo das cores, e os seus mistérios. Ao se aproximar do mundo das cores, das pinturas e dos desenhos; o aluno tende a se apropriar de novos conhecimentos com mais facilidade ao desenvolver suas habilidades artísticas. Ao desenvolver essas habilidades em 
sala de aula a partir principalmente da educação infantil, que é o início da Educação Básica, o professor estimula no aluno diferentes formas de saberes por meio de uma comunicação e representação de ideias que podem ser exploradas, desenvolvendo a partir daí a linguagem oral em busca do mundo da escrita.

Nesse contexto, pode-se promover a construção da linguagem, pois o aluno apresenta experiências pessoais em que esse expõe suas ideias, através de imagens e desenhos. Cabe ao professor assegurar aos alunos durante a aplicação dessa forma de aprendizagem, o direito de pensar, expressar seus sentimentos, negociar suas ideias e criar outras a partir de estímulos que podem partir da liberdade de se expressar que a ele for dada.

Ainda falando da história, Marc Bloch pensou nas relações em que o passado e o presente se entrecruzam ao longo da história. Esse fato pode ser percebido aqui, pois aqueles que um dia foram alunos, na maioria das vezes retornam a escola, e aparecem de outra forma, ocupando um diferente papel na história dessa comunidade. Esses atores retornam a esse espaço como pais de alunos, ou como funcionários, ou mesmo como integrantes da comunidade... Ao considerar uma passagem histórica, deveria se perceber que a história não só deveria permitir e compreender o "presente pelo passado" - atitude tradicional mas também compreender o "passado pelo presente".

Fotos tiradas em um passado distante, ou mesmo próximo ajudam a construir a história, ou as histórias coletivas ou individuais da comunidade retratada nessas imagens.

Para Benedetto Croce em La stone come pensiero e cone azione, "toda a história" é "história contemporânea", e essa história pode ser marcada por fatos, e registradas por fotos e imagens de eventos, jogos, festas... As fotos que seguem mostram o C. M. Dr. Aurelino G. Barbosa uma das escolas objeto da pesquisa em diferentes momentos de inter-relação pessoal. 


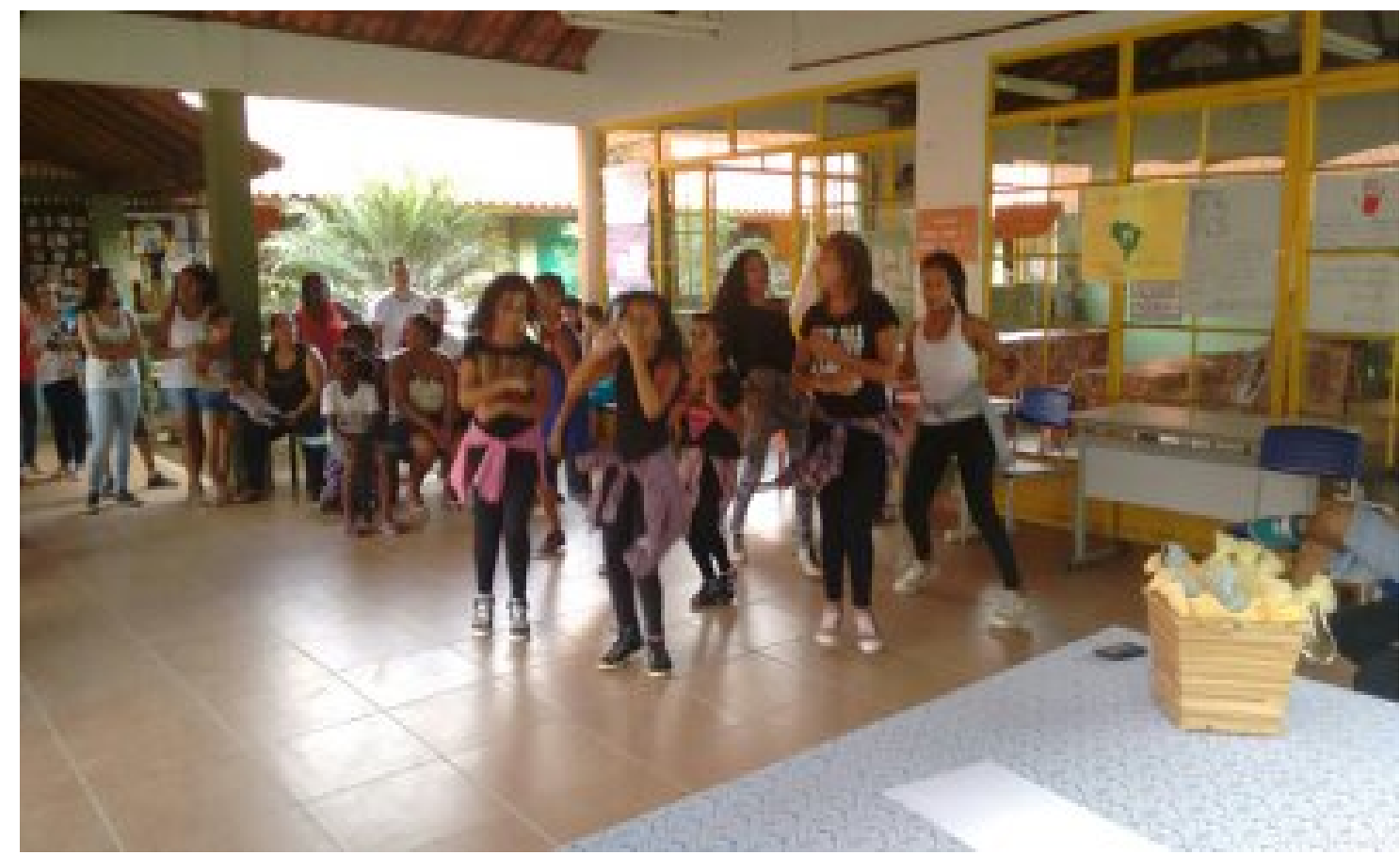

Figura 5 - Os alunos do C. M. Dr. Aurelino G. Barbosa se apresentando em uma confraternização.

U

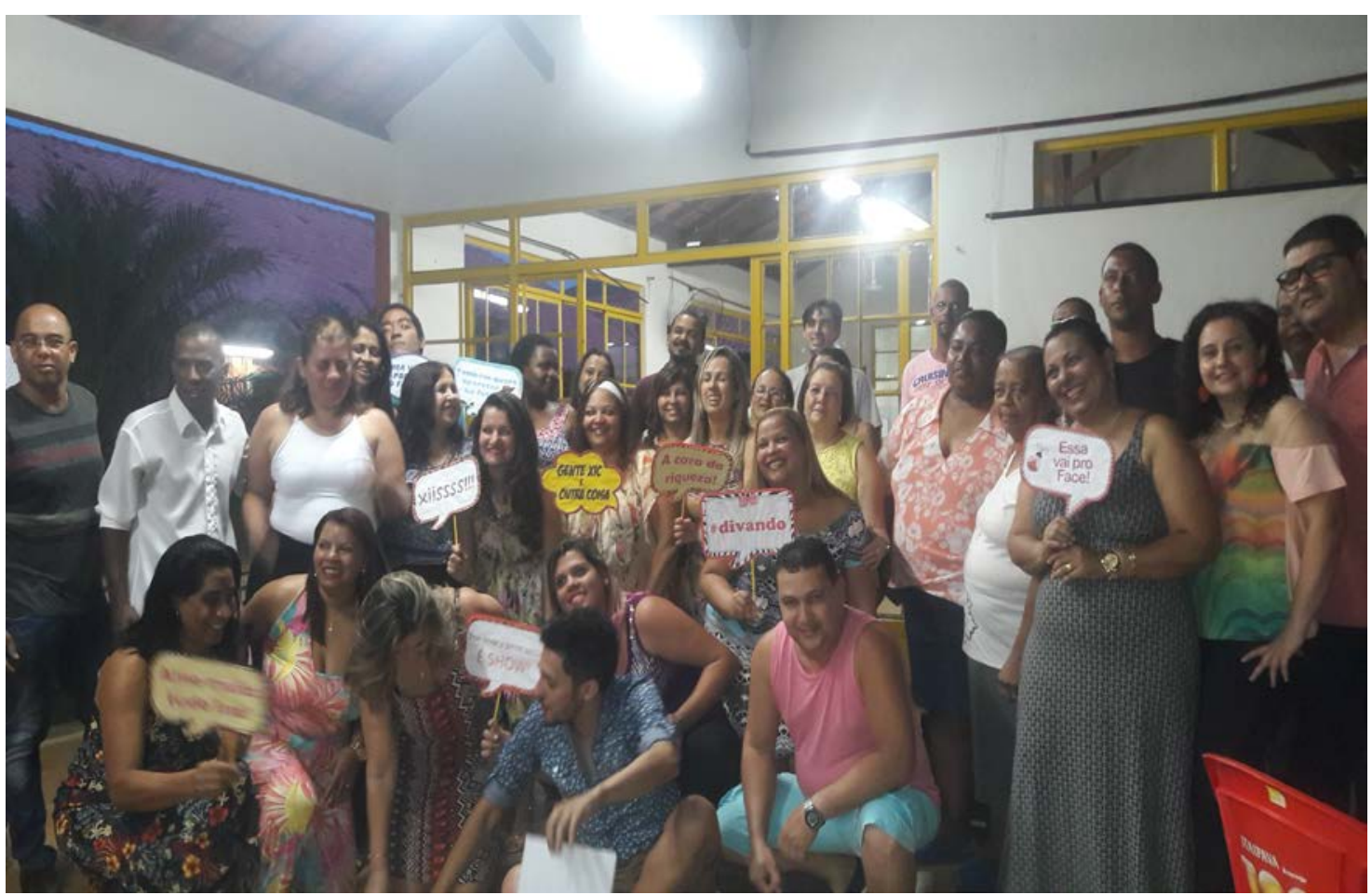

Figura 6 - Funcionários do C. M. Dr. Aurelino G. Barbosa em uma Confraternização 2015. 


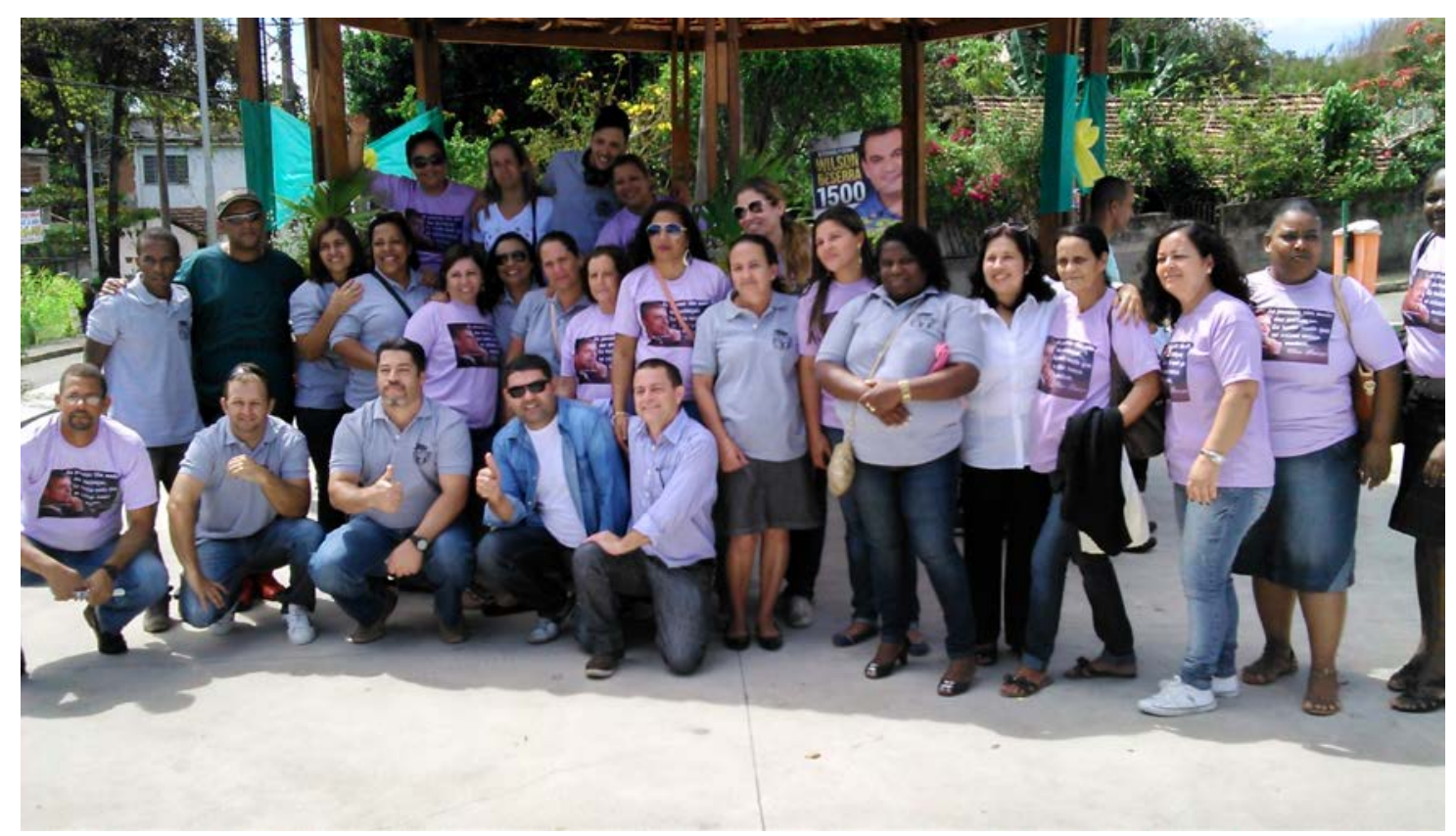

Figura 7 - Foto tirada após o Desfile Cívico do C. M. Dr. Aurelino G. Barbosa professores, funcionários e Prefeito - 2014.

A partir dessas fotos mostradas acima, pode-se afirmar que Croce quer dizer que "por mais afastados no tempo que pareçam os acontecimentos de que se trata, na realidade a história; essa se liga às necessidades e às situações presentes nas quais esses acontecimentos têm ressonância" através das imagens que são feitas desses eventos. De fato, através deste conceito pode-se perceber que Croce pensa que, a partir do momento em que os acontecimentos históricos são repensados constantemente, estes deixam de estar presentes "no tempo"; para então ela a história tornar-se o "conhecimento do eterno presente". (Benedetto Croce in LE GOFF, p. 28)

A dependência que a história do passado tem em relação ao presente deve levar o historiador a tomar certas precauções. Essa dependência é inevitável e legítima, na medida em que o passado não deixa de viver e de se tornar presente. Esta longa duração do passado não deve, no entanto, impedir ao historiador de se distanciar do passado, este distanciamento deve ser reverente, necessário apenas para respeitá-lo e evitar o anacronismo (atitude ou fato que não está de acordo com sua época).

Didi-Huberman (2014, p.11) afirma que o historiador parece constituir a evidência das evidências: a recusa do anacronismo; não um anacronismo para aquele tempo, mas sim para além do tempo. A regra de ouro não seria apenas “projetar” nossas próprias realidades sobre as realidades do passado. Não se pode 
afirmar que seja uma evidência, que a "chave” para compreender um objeto do passado se encontra no próprio passado e, ainda mais, no mesmo passado que o passado do objeto.

Para LE GOFF a história é bem a ciência do passado, com a condição de saber que este passado se torna objeto da história, por uma reconstrução incessantemente reposta em causa.

A interação entre passado e presente é aquilo a que se pode chamar de a função social do passado ou da história. Também para Lucien Febvre: "A história recolhe sistematicamente, classificando e agrupando os fatos passados, em função das suas necessidades atuais, e em função da vida”. Como afirma esse autor, ao se organizar o passado em função do presente: se poderia definir assim a função social da história. (LUCIEN FEBVRE 1949 in LE GOFF 2014, p. 29)

Para LE GOFF (2014, p. 36), a contradição mais flagrante da história é sem dúvida o fato do seu objeto ser singular, um acontecimento, uma série de acontecimentos, de personagens que só existem uma vez, enquanto que o seu objetivo, como o de todas as ciências, é atingir o universal, o geral, o regular.

Como afirmam alguns historiadores, no concernente a história da história, esta não deve preocupar-se apenas com a produção histórica profissional; ou mesmo com a história dos historiadores, mas sim com todo um conjunto de fenômenos que podem vir a constituir a cultura histórica ou, melhor, a mentalidade histórica de uma época. Um estudo dos manuais escolares de história é um aspecto privilegiado, mas esses manuais praticamente só passaram a existir depois do século XIX.

Segundo Le Goff (1990, p. 88), “tal como o passado não é a história, mas o seu objeto; também a memória não é a história, mas um dos seus objetos e simultaneamente um nível elementar de elaboração histórica”. A partir dessa concepção Le Goff afirma que a revista "Dialectiques" publicou no período de (1980) um número especial em que consagrava celebremente às relações entre “Memória e História”. Para ele uma ciência histórica autogerida não só seria um desastre como não faria sentido, pois a história, mesmo que só o consiga vagamente, é uma ciência e depende de um saber profissionalmente adquirido. É evidente que a história não atingiu o grau de tecnicismo das ciências da natureza ou da vida, e não se pode desejar que o atingisse para que pudesse continuar a ser 
facilmente compreensível e até controlável pelo maior número de pessoas. A história já tem a sorte ou a infelicidade (única entre todas as ciências) de poder ser feita convenientemente pelos amadores. Podemos aqui observar o trabalho em um projeto de ciências de alunos e professores que desenvolveram um experimento em ciências no C. M. Doutor Aurelino G. Barbosa que os levou a participarem da 'Feira de Ciências a Nível Estadual' com esse experimento, que era uma estufa em que eles conseguiam utilizar para fazer banana passa. Um trabalho, às vezes desenvolvido por amadores, mas que acabam tendo visibilidade dependendo do lugar ou local em que esses foram expostos.

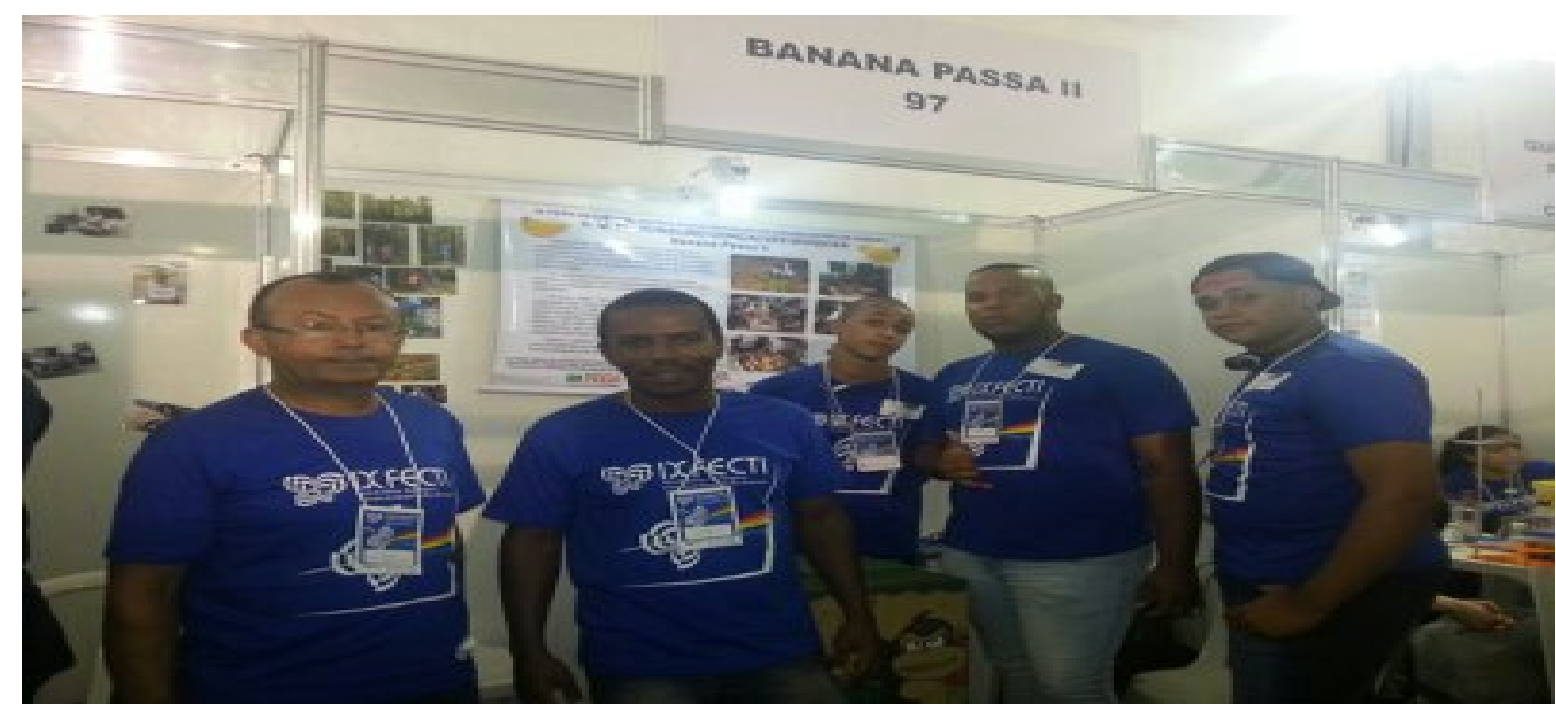

Figura 8 - Professores de ciências e alunos na Feira Estadual - 2015.

De fato, a História como um objeto também passível de estudo científico tem necessidade de vulgarização - e os historiadores profissionais nem sempre se dignam a ceder a esta função, no entanto essencial e digna, da qual se sentem incapazes; mas a era dos novos media multiplicou a necessidade e as ocasiões para que existam mediadores semi-profissionais que permitem que esses fatos aconteçam.

Segundo Le Goff (1990, p. 89), no início do século XIX a história era quase nada. O historicismo em diversos aspectos, quis fazer tudo. A história não deveria reger as outras ciências e, menos ainda, a sociedade. Mas, tal como o físico, o matemático, o biólogo - e, de outro modo, os especialistas de ciências humanas e sociais -, o historiador também deve ser ouvido, ou seja, a história deve ser considerada como um ramo fundamental do saber. 
Tal qual “as relações entre Memória e História”, também as relações entre passado e presente não devem levar à confusão e ao ceticismo. Sabe-se agora que o passado depende parcialmente do presente. Toda a história é bem contemporânea, na medida em que o passado é apreendido no presente e responde, portanto, aos seus interesses, o que não é só inevitável, como legítimo esse momento cabe à memória perpetuá-lo. Nesse contexto, a história tem o seu tempo de duração, sendo assim, o passado é ao mesmo tempo passado e presente, porque um remete ao outro. Compete nesse caso ao historiador fazer um estudo "objetivo" do passado sob a sua dupla forma. O historiador estando comprometido com a história, não atingirá certamente a verdadeira "objetividade", mas nenhuma outra história é possível se não houver a ação do tempo e a recapitulação da memória. Sabe-se também que a evolução do mundo nos leva a pôr em análise as sociedades em termos de poder. Sendo assim, esta problemática passou a fazer parte da história; atualmente é possível observar que há um recorte da história que nos leva ao pensamento conservador que acostumado com o poder de casta, não aceita a ascensão da classe considerada por eles subalterna, por questões seja essas raciais ou mesmo econômica. Aqui já podemos falar de Ranciere (2014) que nos fala da 'partilha do sensível'. Tudo que se encontra registrado aqui nos leva a escrita das memórias pela história, uma fundamenta-se na outra. Temos na escola pública o ranço de uma sociedade que depende dos que ali estão para crescer, sendo assim sabe-se que enquanto professor se não houver o envolvimento da comunidade escolar, jamais atingiremos o que se deseja em matéria de educação. Pode-se afirmar com certeza que 'A Educação é política', como nos ensinou Freire.

A cultura (ou mentalidade) histórica não depende apenas das relações memória- história, presente-passado. A história é a ciência do tempo. Está estritamente ligada às diferentes concepções de tempo que existem numa sociedade e é um elemento essencial da aparelhagem mental dos seus historiadores, em seus processos de criação da história. Isso é um fato que não foge ao olhar de um bom observador, para que uma prática educativa dê certo, é preciso que todos que estão inseridos no contexto escolar se envolvam para a sua efetivação.

Na concepção de Jacques Le Goff (1990): 
“A Memória é o elemento essencial da chamada identidade individual, ou coletiva; cuja busca é uma das atividades fundamentais dos indivíduos, e das sociedades de hoje; na febre e na angústia”. (LE GOFF, 1990, p. 476).

A reflexão que se pode fazer a respeito desta definição, nos leva ao universo das lembranças sociais, das memórias que representam a formação e a preservação da cultura e da identidade dos povos. Ao se pensar e repensar como se dá a formação da memória esse fato implica, obrigatoriamente, no refletir acerca de elementos culturais que fazem parte da história, seja ela recente, ou não. Pode-se afirmar a partir das leituras feitas, que não há história sem memória. A Foto que segue traz os dizeres ' $O$ adulto, que não brincou quando criança. Faltalhe um pedaço no coração’. Uma verdade, se não há história, como pode haver memória?

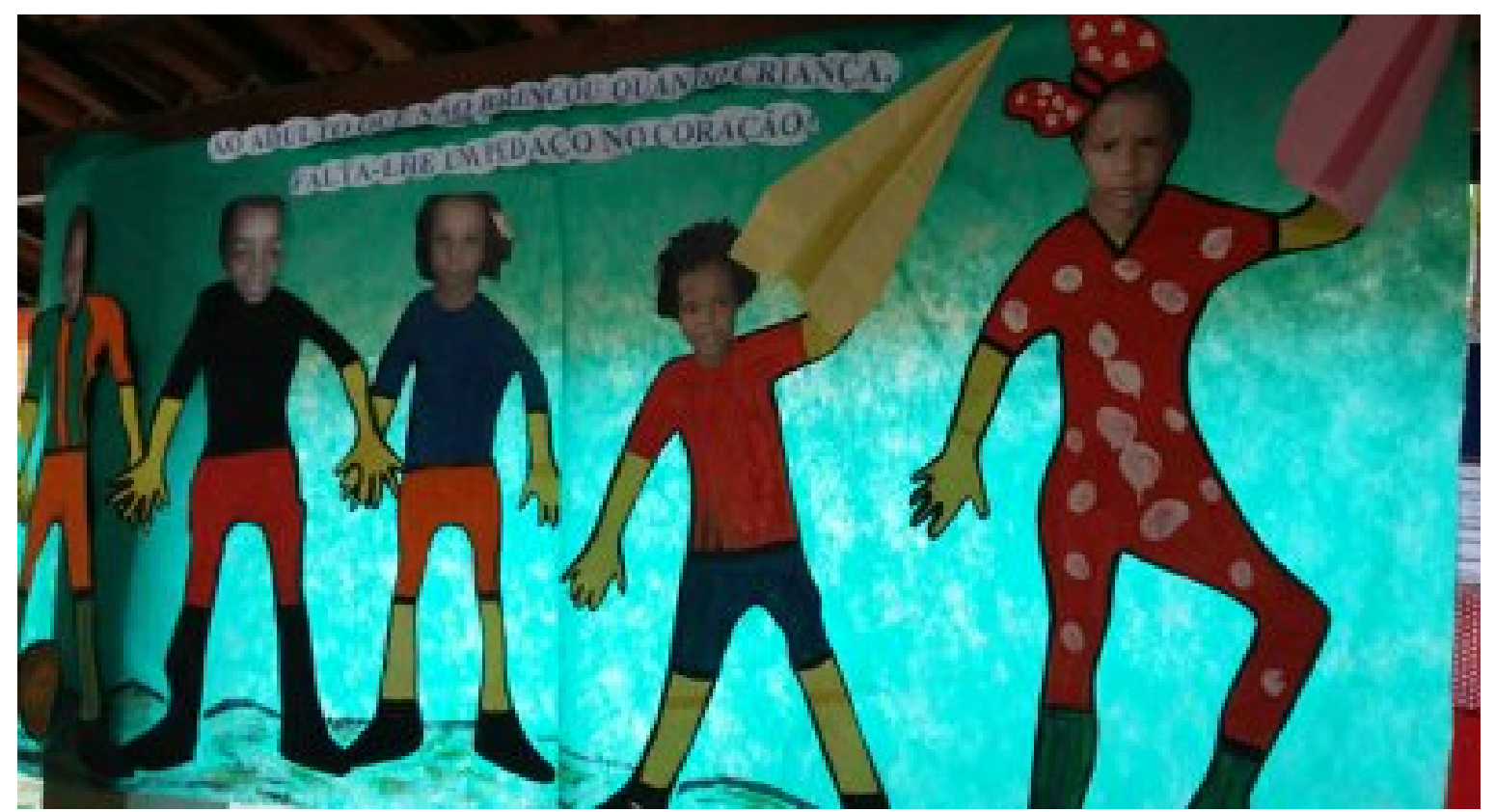

Figura 9 - alunos do Ensino Fundamental I do C. M. Doutor Aurelino G. Barbosa - Painel de imagens.

Segundo HALBWACHS um importante sociólogo francês que se dedicou a estudos sobre a memória, as relações a serem determinadas não devem ficar apenas limitadas ao universo individual, mas sim se estenderem à realidade interpessoal das instituições sociais. No caso descrito aqui, essa instituição é a escola pública em busca de qualidade. Para ele a memória do indivíduo depende do seu relacionamento com a família, com a classe social, com a escola, com a religião, com a profissão, enfim, com os grupos de convívio e os grupos de 
referência peculiares a esse indivíduo e vice versa. Pode-se exemplificar aqui com as fotos dos desfiles cívicos das escolas, pois esse é um momento em que ocorre uma troca de relações pessoais em busca de um ato Cívico que se torna um encontro entre todas as escolas dos municípios; e também um encontro das diferentes comunidades que fazem parte dessas escolas; as famílias participam do acontecimento por desejarem fotografar os seus familiares que estão ali fazendo parte do evento. Com certeza para eles enquanto seres sociais, essa é uma forma de cristalizar aquele momento no tempo...

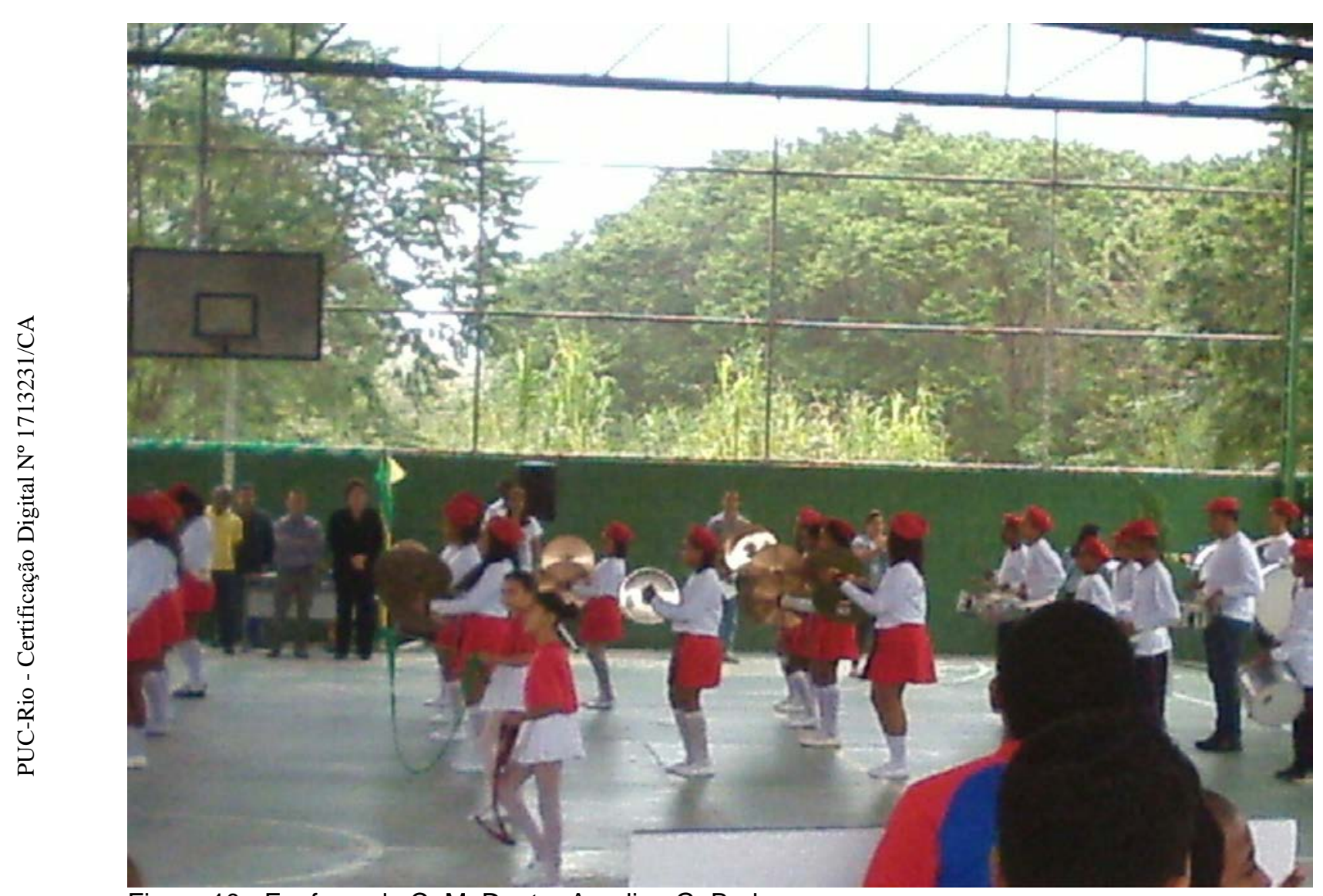

Figura 10 - Fanfarra do C. M. Doutor Aurelino G. Barbosa. 


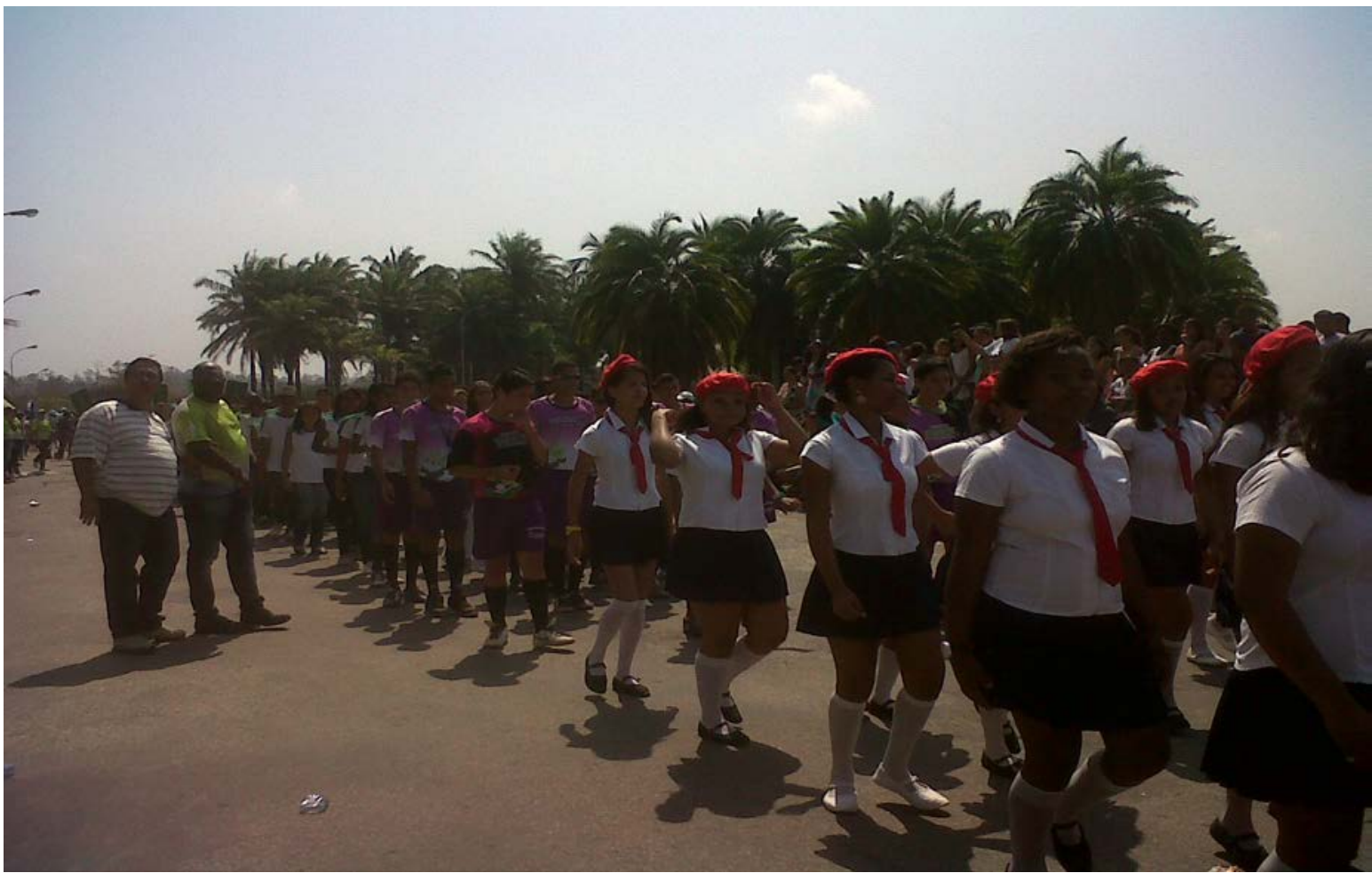

Figura 11 - Desfile Cívico da E. M. Panaro Figueira no Campus da UFRRJ - 2012.

Uू

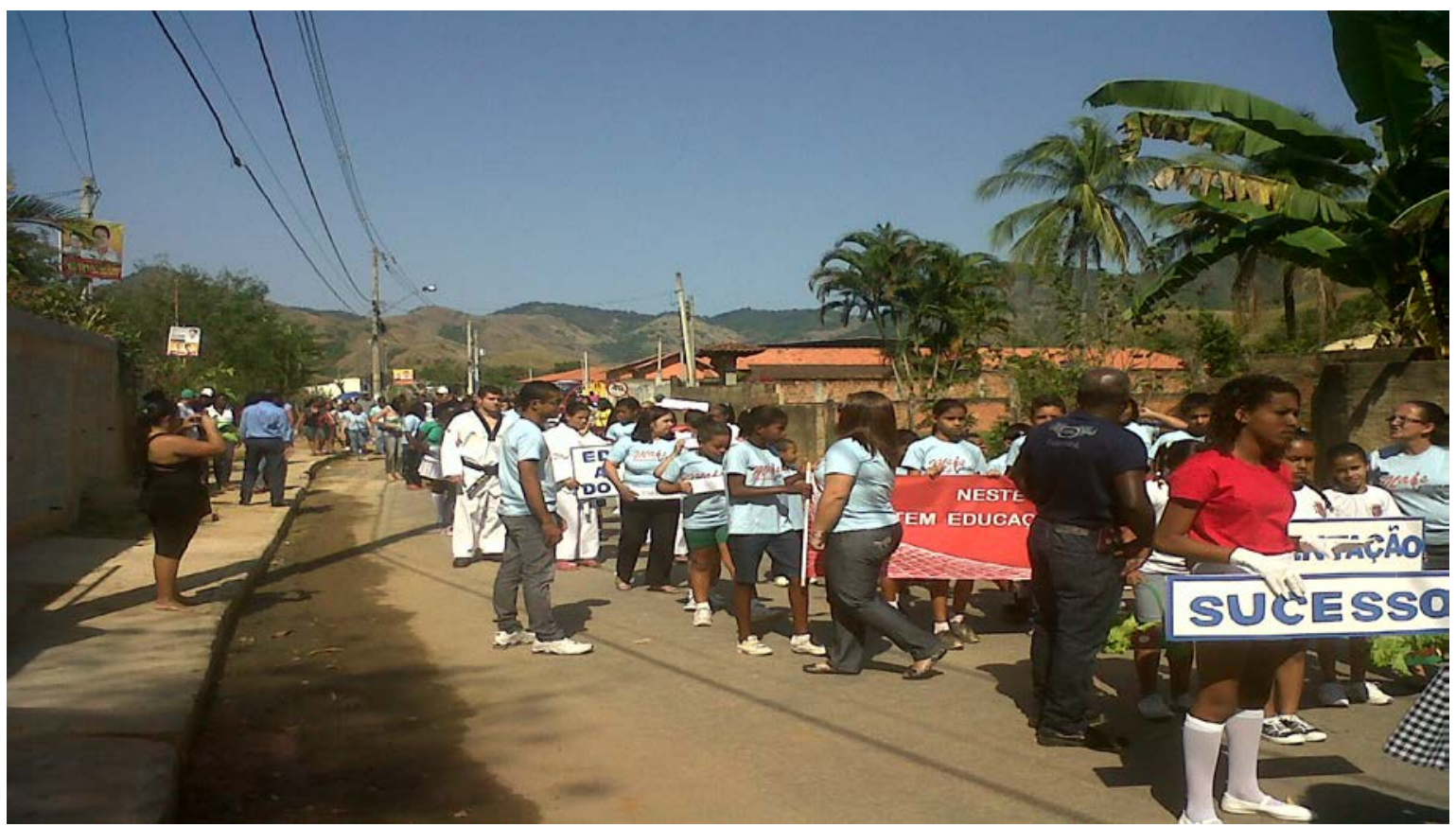

Figura 12 - Desfile Cívico na Comunidade de Cacaria Piraí - 2012. 


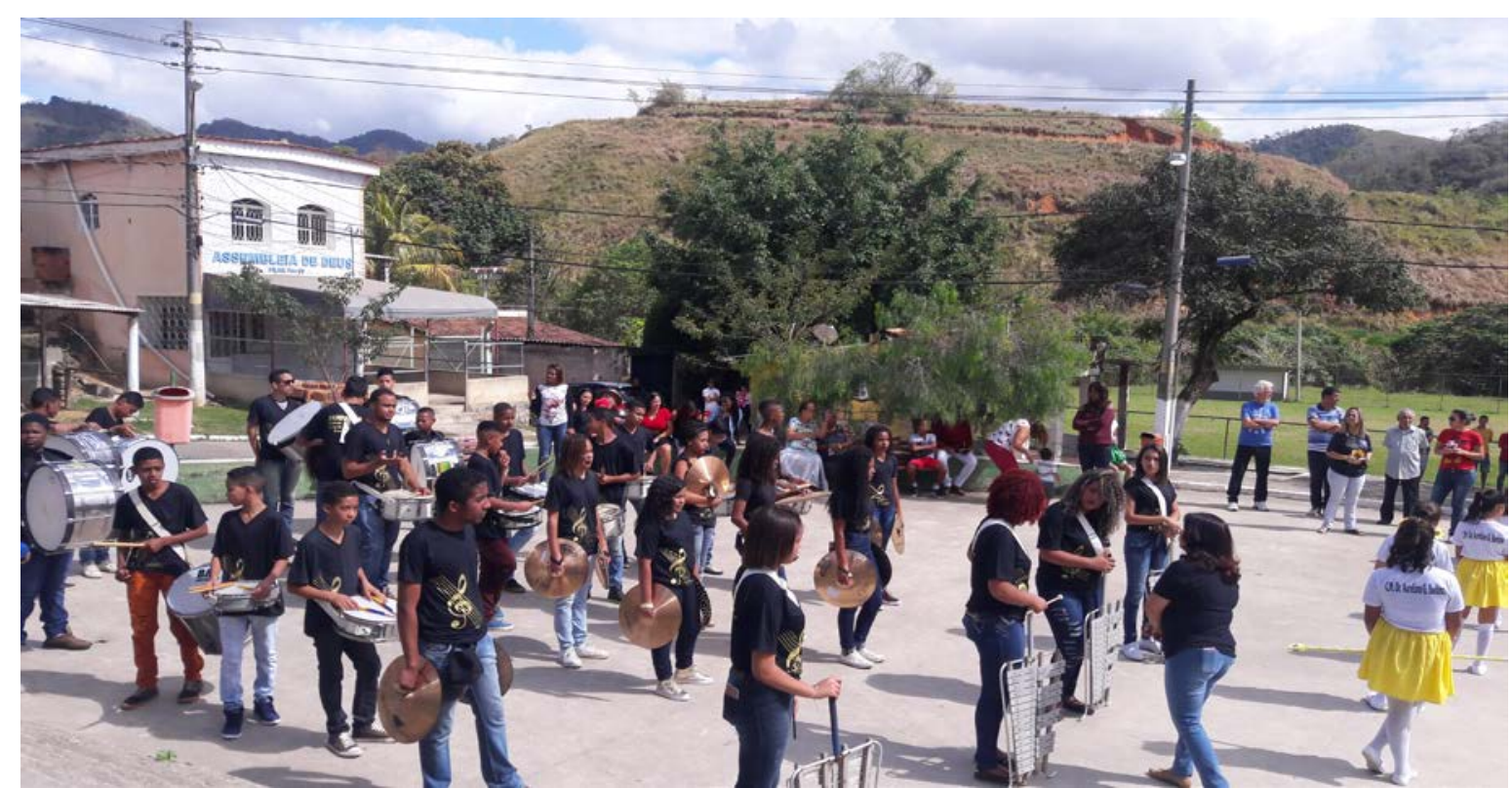

Figura 13 - Desfile Cívico do C. M. Doutor Aurelino G. Barbosa na Comunidade de Cacaria - Piraí - 2017.

HALBWACHS (1990, p. 53) ao aprofundar-se em estudos que envolvem o conhecimento da memória coletiva e da memória histórica; tece uma análise distintiva entre memória autobiográfica e memória social. A memória social mostra que o indivíduo busca guardar em si fatos que envolvem o grupo social do qual esse faz parte. Segundo as investigações desse teórico francês, nascido em 1877, às lembranças agrupam-se em duas espécies de memórias, das quais o indivíduo participa, adotando atitudes diferentes diante de cada uma. A memória autobiográfica que se ocupa das lembranças ligadas à sua personalidade, à sua vida pessoal; nos casos representados acima através das fotos, aparecem na forma de fotografias de eventos em que pessoas da família ou amigos dos alunos participam. Enquanto que a memória histórica destina-se à sua participação como membro de um grupo social contribuindo para aqueles acontecimentos “(...) evocar e manter as lembranças impessoais, na medida em que estas interessam ao grupo.” (HALBWACHS, 1990, p. 53).

Mesmo distintas; essas memórias apresentam pontos de interseção em algumas situações, mas seguem seus próprios caminhos.

Na concepção de LE Goff (2014, p. 32):

"Há pelo menos duas histórias: a da memória coletiva e a dos historiadores. A história da memória coletiva é essencialmente mítica, deformada, anacrônica, mas constitui o vivido desta relação nunca acabada entre o presente e o passado. É desejável que a informação histórica, fornecida pelos historiadores de ofício, 
vulgarizada pela escola (ou pelo menos deveria sê-lo) e pelo mass media, corrija esta história tradicional falseada. A história deveria esclarecer a memória e ajudála a retificar os seus erros. Mas estará o historiador imunizado contra uma doença, se não do passado, pelo menos do presente e, talvez, uma imagem inconsciente de um futuro sonhado?” (LE GOFF, 2014, p. 32)

No que tange a memória individual, esta em alguns momentos, penetra a coletiva, apoiando-se sobre ela em situações nas quais esta precisa confirmar algumas de suas lembranças ou dar-lhes precisão, de modo a preencher algumas de suas lacunas. Já a memória coletiva envolve as memórias individuais, mas não deve ser confundida com elas. Pode-se justificar a junção dessas memórias, de forma a retomar seu próprio passado, pois o ser humano, frequentemente, precisa buscar apoio nas lembranças dos outros, reportando-se a referências que existam fora dele; e que sejam fixadas pela sociedade. Não é possível o funcionamento da memória individual sem o instrumento, que são as palavras e as ideias, pertencentes e decorrentes de um meio, não pertencentes a um único indivíduo. É necessário que o indivíduo faça parte de uma sociedade para que ele tenha enfim, essa memória coletiva. Memória essa composta de diferentes fatos sociais que o levam a vivenciar essa ação no tempo. A fotografia, a gravação de um vídeo desses eventos... Marcam aquela ação através da imagem, pois só através dessas imagens será possível ao indivíduo reviver aquele momento futuramente.

Este fato mostra a relevância de um estudo que seja feito paralelo a essas duas memórias, evidenciando que as mesmas se completam, por haver entre elas uma relação de coexistência.

Para HALBWACHS (1990, p. 55) no decorrer da vida, um indivíduo tem a capacidade de resguardar suas lembranças pessoais, e também pode compor um painel de memórias adquiridas por intermédio do depoimento de outras pessoas. Essas memórias são as que não foram vivenciadas diretamente. Entretanto, integram os conhecimentos que cada indivíduo tem de si, de sua comunidade, de sua cidade, de seu país e do mundo.

Pode-se afirmar que essas memórias são “emprestadas”, pois servem ao homem como bagagem de lembranças históricas. Os registros desses trabalhos e eventos que foram vivenciados, nos dão margem para descrever essas vivências como espectador, ou como colaborador, tanto minhas como a de outros educadores que fizeram parte dessa pesquisa, pois eles foram peças essenciais 
para que juntos pudéssemos realizar o que se pretendeu, pois cada um atuou dentro do projeto, colaborando de alguma forma.

Partindo desse contexto, verificou-se assim a distinção entre essas duas memórias:

[...] uma interior ou interna, a outra exterior; ou seja, uma memória pessoal, e a outra memória social. Como se poderia dizer de forma mais exata: memória autobiográfica e memória histórica (HALBWACHS 1990, p. 55)

Sendo que como já se observou anteriormente, essa memória autobiográfica se apoia na memória histórica, pois toda história da vida humana faz parte da história em geral. Mas a segunda seria, naturalmente, bem mais ampla do que a primeira. Por conseguinte, ela não nos representaria no passado senão sob uma forma resumida e esquemática, enquanto a memória de nossa vida nos apresentaria um quadro bem mais contínuo e mais denso.

Muitas lembranças e experiências pessoais são compartilhadas entre estas memórias, como já se falou anteriormente, pois uma se apoia na outra. Desta forma, também acontece na história vivida, e não apenas na história aprendida, na qual se pode ancorar nossa memória subjetiva.

Sendo assim, pode-se tentar entender por história uma sucessão cronológica de acontecimentos e de datas, e também tudo aquilo que faz com que um período se distinga dos outros, e cujos livros e narrativas não nos apresentam em geral senão apenas um quadro bem esquemático e incompleto. Pode-se perceber isso através das fotos que seguem, cada momento é único. Não há como esses momentos se repetirem de forma igual no tempo, mesmo que esses eventos sejam realizados com a mesma finalidade, o tempo os fez se tornar passado, a história se faz a partir daí. Essa é revivida através das lembranças e das memórias. 


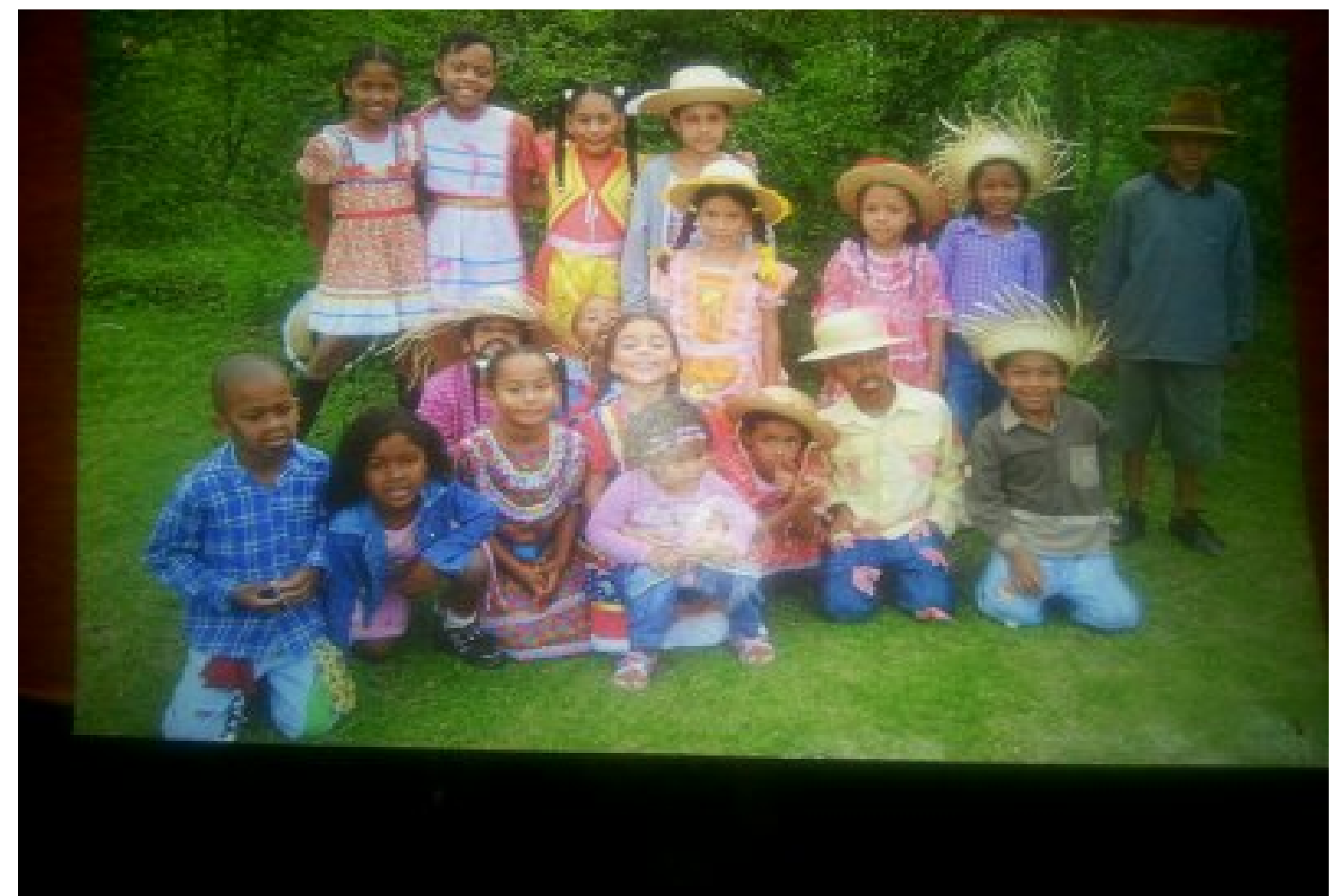

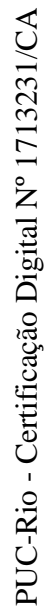

Figura 14 - Alunos do Ensino Fundamental I em 2010 - Hoje estão no Ensino Médio 2019.

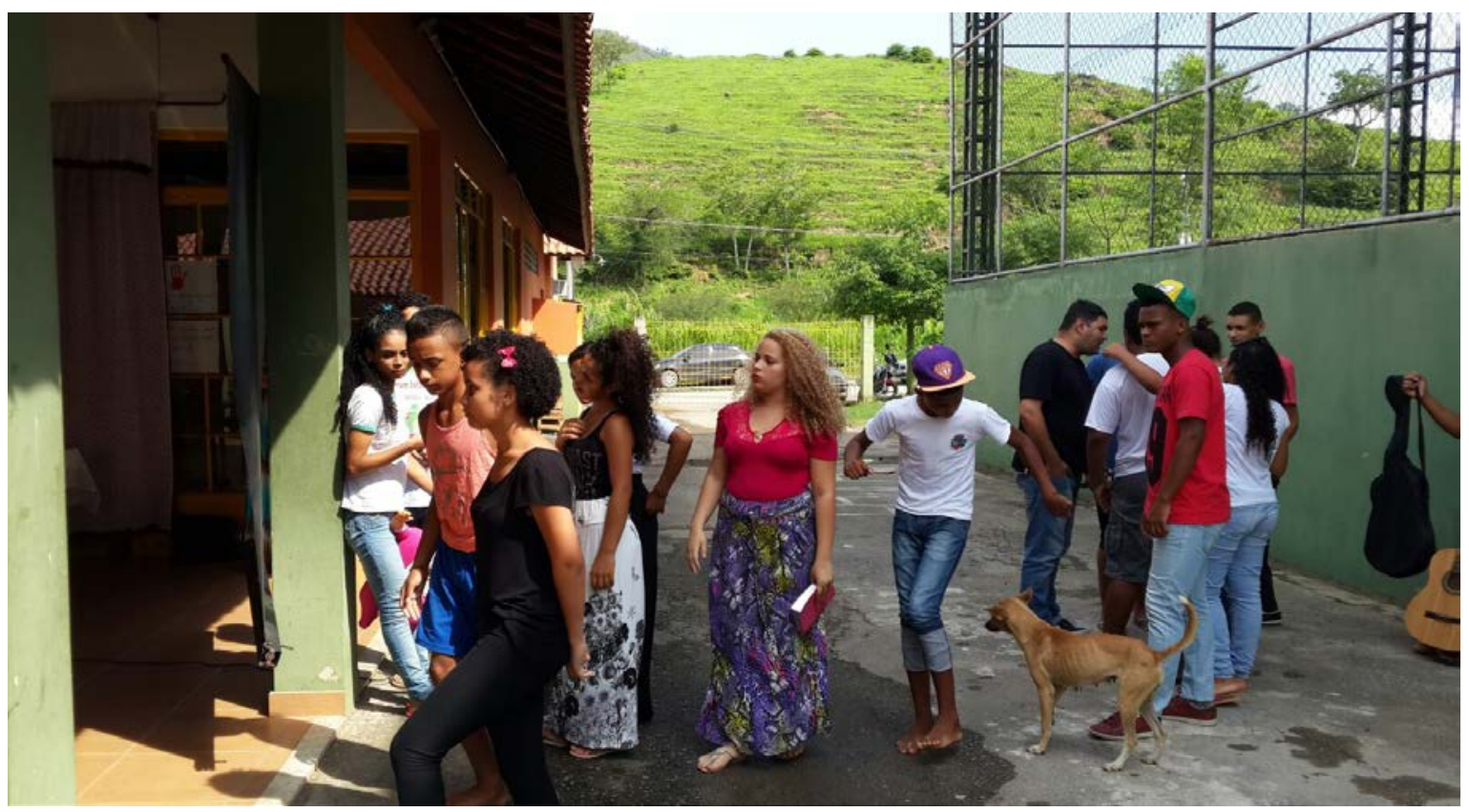

Figura 15 - Alunos do E. Médio junto com alunos do E. Fundamental em uma representação cultural - 2016. 


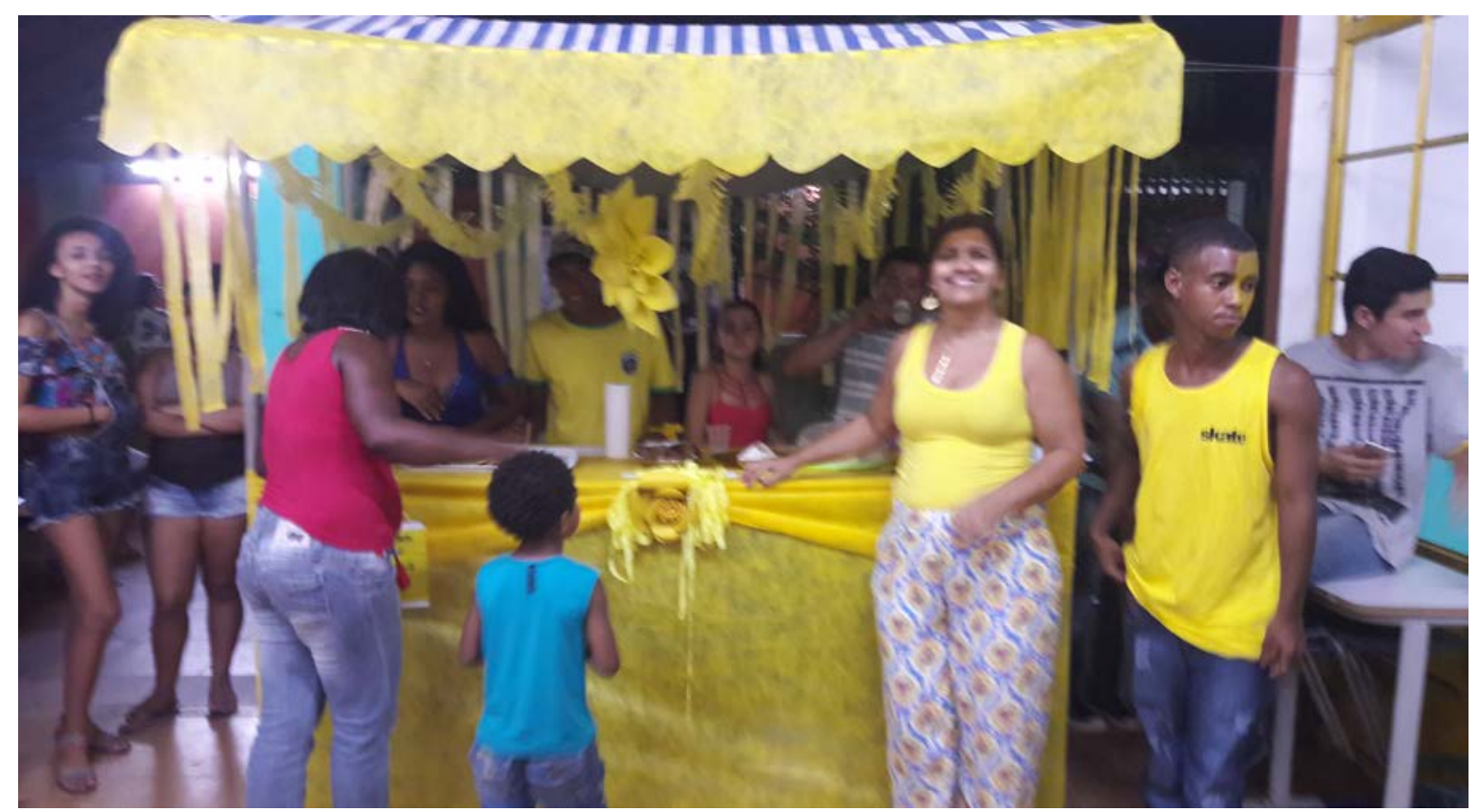

Figura 16 - Alunos da EJA e do Ensino Médio na Gincana Cultural - 2017.

LE GOFF (1990) afirma que ninguém vive o presente imediato, pois todo indivíduo liga coisas e fatos graças à 'função adesiva' das memórias pessoal e coletiva que se relacionam com a história e com os mitos. Por que para o historiador, o relacionamento perceptual humano com o mundo funciona porque, este confia e sempre confiou em histórias anteriores. (LE GOFF, 1990, p. 478).

Para HALBWACHS (1990, p. 66) "no contexto histórico que engloba as culturas tradicionais da África, que são a base cultural da formação do povo brasileiro, as 'verdades' individuais e coletivas se baseiam nos relatos de ancestrais”. O idoso sempre teve um papel importante na construção da memória do 'presente', pois sua própria existência revelava épocas passadas, pois ele era a prova viva de que vivenciara um universo temporal anterior. Em muitos momentos de minha vida, eu, meus irmãos e amigos nos sentamos no quintal de nossa casa para ouvirmos histórias contadas pelos nossos pais, tios e avós. Histórias essas que contribuíram para a construção dessa forma de reconhecer no mundo diferentes modos de aprendizagem para vida, que foram levadas para o espaço escolar, palco hoje de uma visão diferenciada de práticas educativas que são desenvolvidas através da parceria com outros professores e profissionais da educação, que conviveram com essas mesmas histórias, quando não participaram dessas memórias, foram espectadores das mesmas. Alguns fizeram parte dessas vivências, outros que passaram a compor o novo modelo de amizade e 
companheirismo criado para realizar o desejado no âmbito da educação, eram parceiros de uma vida, em busca da escrita de histórias de outras vidas... Passeios, viagens, festas, danças, jogos, brincadeiras... Quando se fala de passeios, recordome das idas com os alunos de todas as escolas Estaduais e Municipais em que trabalhei aos parques de diversões: “Tivoli Park” na Lagoa, nos anos de 1992 até o parque fechar; “Terra Encantada” durante todo o tempo que este parque esteve aberto; por último ao "Water Planet” em Jacarepaguá. Todos estes parques tinham uma máquina que se podia cantar músicas ao vivo, era divertido, como dizia os alunos “pagávamos micos”. Ao entrar naquele clima de alegria e divertimento, transformamos vidas, esse fato foi constatado por nós professores, pelos relatos desses alunos em redações que eram escritas após esses passeios, pois muitos desses alunos nunca haviam ido a um parque de diversões, pois as famílias não possuíam condição para tanto. Para pagar as entradas na maioria das vezes fazíamos rifas com objetos doados por comerciantes e políticos locais, fazíamos festas nas escolas com barracas que tinham o intuito de custear esses passeios para aqueles que não tinham condições financeiras para tanto. Com isso, socializamos esses alunos, tornaram-se outras pessoas, com outras mentalidades 'afirmação feita por eles mesmos em seus relatos'. Para realizarmos essas ações costumávamos reunir um grupo de professores que se envolviam nesses eventos, professores praticamente de todas as disciplinas. Já éramos “interdisciplinares” mesmo antes dessa palavra entrar para o vocabulário da Educação. A cada passeio realizado, conseguíamos levar uma média de 120 alunos, tínhamos prefeitos e vereadores parceiros, nem tudo era ruim. Era um tempo de sonhos... Levávamos lanches, dávamos antes de sair da escola almoço para todos, e só saíamos do parque quando esse fechava. Isso repercutia em sala de aula, pois depois pedíamos aos alunos para descreverem esses passeios... Motivavam-se assim as escritas, surgiam aí os escritores, e através de diferentes olhares tínhamos diferentes histórias escritas e contadas... E esses eventos se tornaram mais frequentes a partir dos anos 2000 em diante, pois os filhos se tornaram pais, os pais se tornaram avós, e queriam que os seus pudessem viver as mesmas coisas que eles viveram...

Como afirma Silva (2009, p 19), uma história vivida se distingue perfeitamente da história escrita, na medida em que se tem o que é preciso para se constituir um quadro vivo e natural, em que um pensamento pode apoiar-se, e dar 
sustentação à memória. Uma história vivida é passível de descrição, pois essa fica latente em sua memória, em suas lembranças. Só aquele que viveu tal história pode contá-la com riqueza de detalhes. Entretanto, pode-se dizer que as lembranças são reconstruídas no presente, pois é com a ajuda de fatos emprestados a este, que são retomados muitos acontecimentos do passado. Retomamos em parte essas vivências...

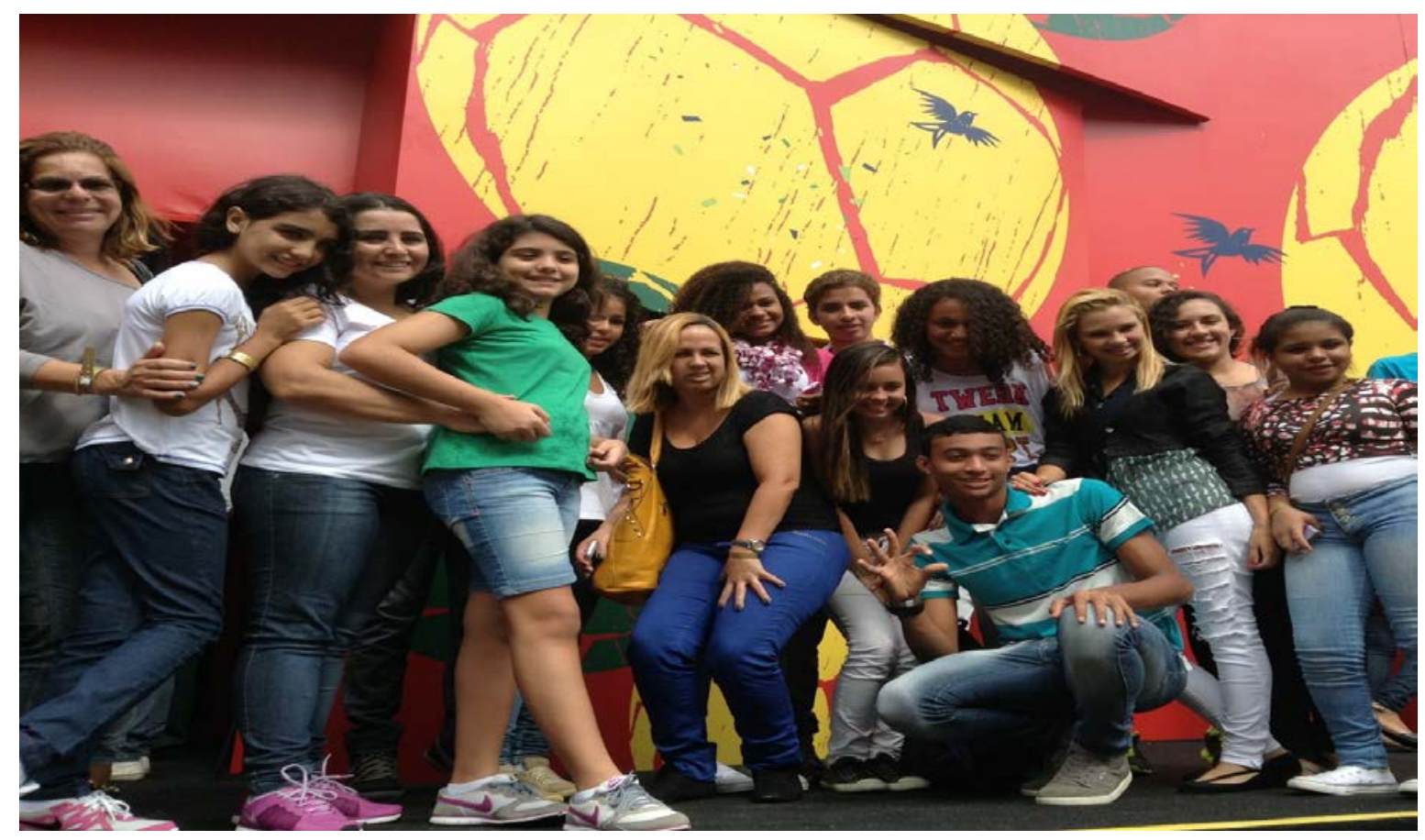

Figura 17 - Alunos de diferentes escolas, de diferentes série em visita ao Tour da Copa montado pela Coca-Cola no Maracanã. 


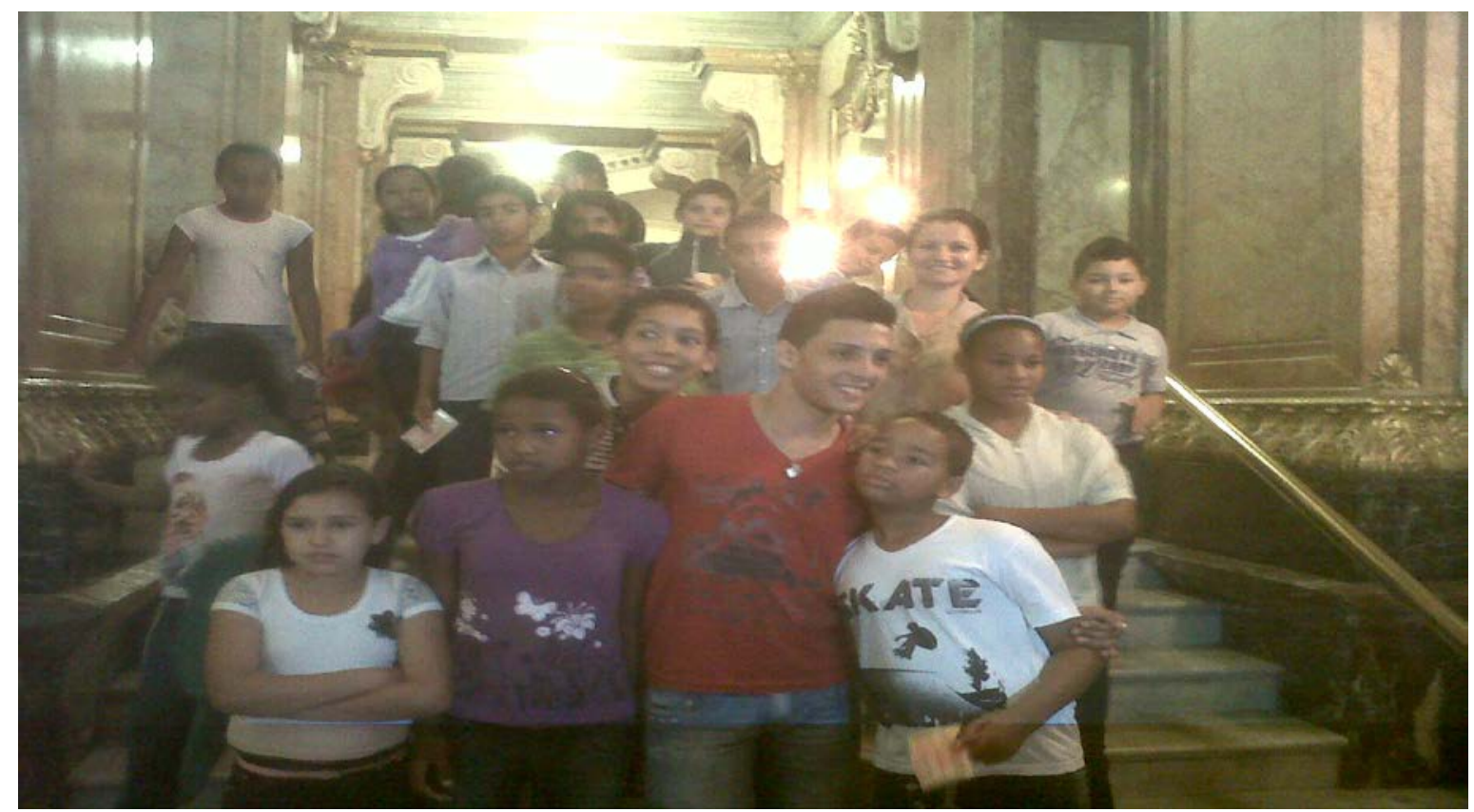

Figura 18 - Passeio ao Teatro Municipal do Rio de Janeiro com alunos do Ensino Fundamental I e II - C. M. Dr. Aurelino G. Barbosa.

Para Silva (2009, p 19): “Segundo o filósofo alemão Walter Benjamin, no que tange ao conceito da história, a verdadeira imagem do passado perpassa veloz; e o passado só se deixa fixar, como imagem que relampeja irreversivelmente, no momento em que é reconhecido. 'A verdade nunca nos escapará'. - essa frase de Gottfried Keller caracteriza o ponto exato em que o historicismo se separa do materialismo histórico. Por que irrecuperável é cada imagem do presente que se dirige ao presente, sem que esse presente se sinta visado por ela”. (BENJAMIN, 1994, p. 224 in SILVA, p 19)

As lembranças não são estáticas, uma vez que elas representam imagens finais de um exercício de constantes e diversas recriações dos fatos. Lembranças mais antigas se juntam às mais novas e compõem assim novas imagens. Os pontos de vista daqueles que se põem a recordar; se modificam de acordo com as vivências pessoais, e com as posições sociais ocupadas em determinados grupos. Eu como educadora hoje vivo e revivo essas memórias com a sensação de dever cumprido no que tange a Educação. Fomos e somos um grupo de educadores que fizemos e ainda fazemos a diferença na vida de nossos alunos.

Segundo Silva (2009, p. 20), “Ecléa Bosi em sua proposta afirma que a memória tem uma função decisiva no processo maior de formação da identidade psicológica, pois esta permite a relação do corpo presente com o passado e, ao mesmo tempo, interfere no processo presente de representações”. 
HALBWACHS, apresentando estudos teóricos de Henri Bergson sobre a memória, destaca exemplificando que “(...) o passado permanece inteiramente dentro de nossa memória, tal como foi para nós; porém, alguns obstáculos, em particular como o comportamento de nosso cérebro, impedem que evoquemos dele todas as partes” (HALBWACHS, 1990, p.12 in SILVA, p. 20).

De acordo com Halbwachs (1990) para Bergson, a lembrança é a sobrevivência do passado que se conserva no íntimo de cada ser humano; passado esse que será atualizado pela consciência na forma de imagens-lembranças. O passado, em sua forma pura, seria a imagem presente em sonhos e devaneios. Para Bergson, há dois tipos de memória: uma objetiva, denominada 'memória-hábito’, e as 'imagens-lembranças' que envolvem as recordações subjetivas que cada ser traz dentro de si. Essas imagens-lembranças fazem parte dos trabalhos que estão representados em algumas fotos, imagens dessas ações e apresentações descritas. Como se pode observar nas fotos abaixo em dois espaços bem diferentes, uma dança ocorre na E. M. Panaro Figueira, e a outra dança ocorre no C. M. Dr. Aurelino G. Barbosa, mas com as mesmas características - reconhecer a cultura do povo brasileiro.

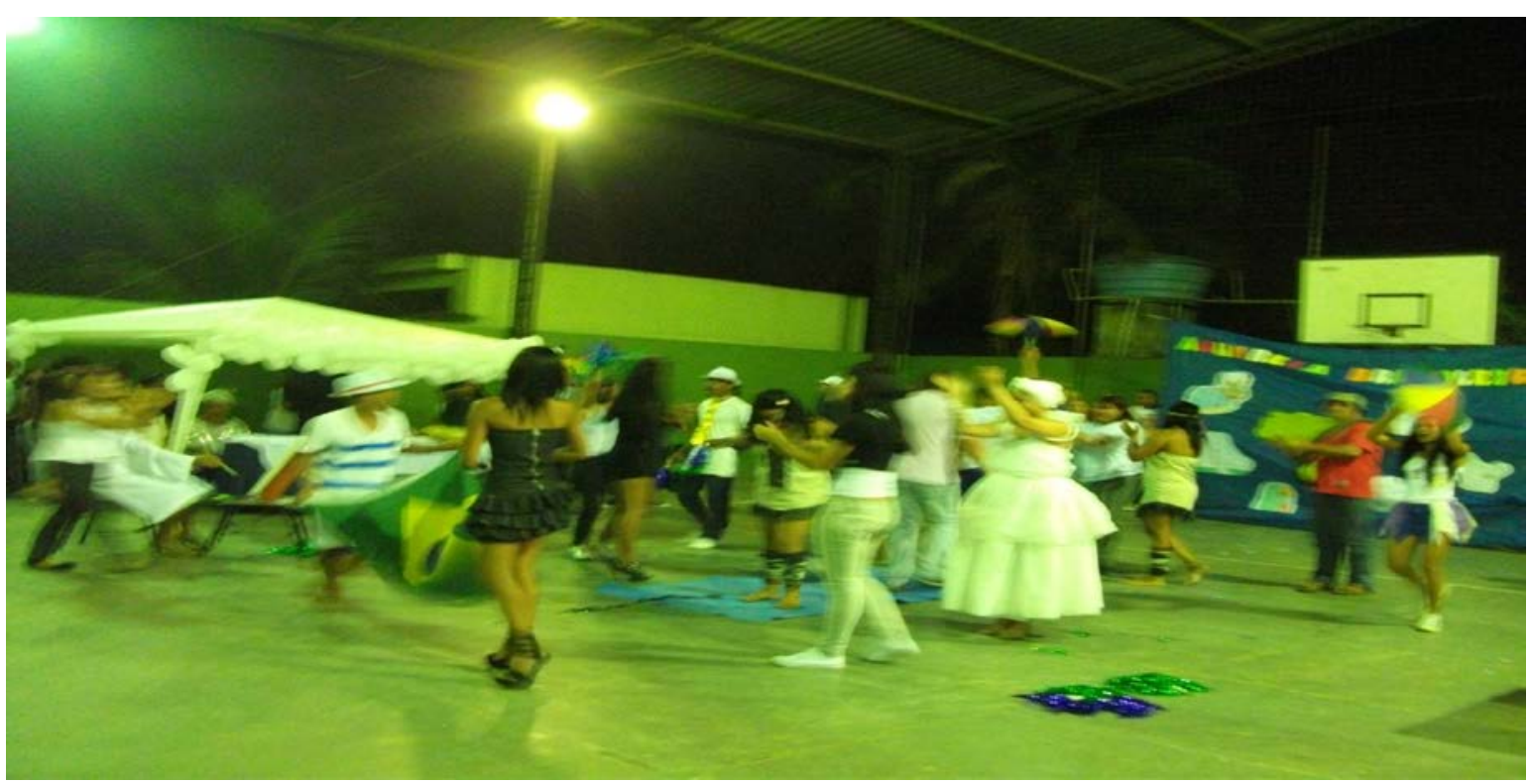

Figura 19 - Dança da música Aquarela do Brasil desenvolvida pelos alunos da EJA da Escola Municipal Panaro Figueira - Ano 2011. 


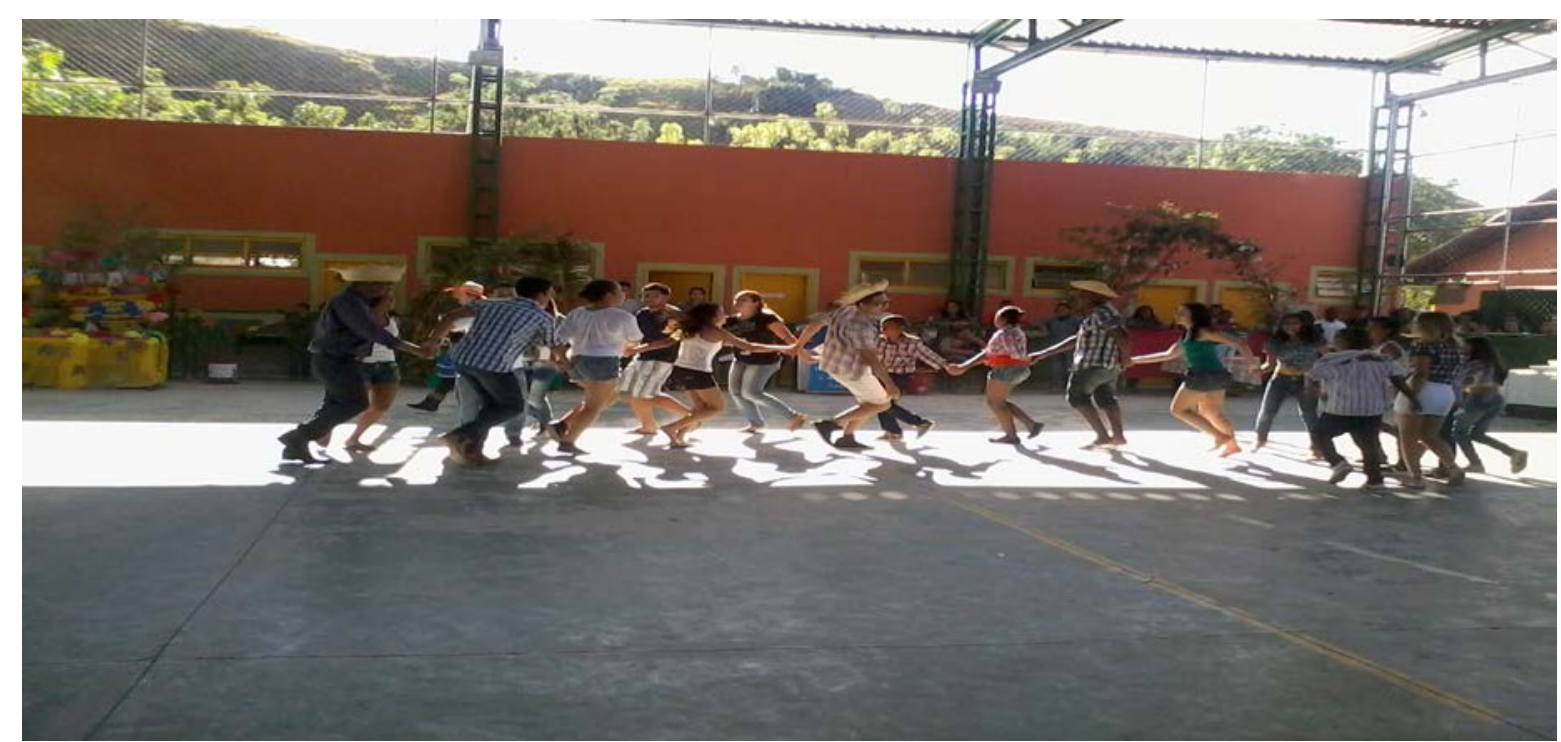

Figura 20 - Dança Caipira Maluca C. M. Doutor Aurelino G. Barbosa - Festa Junina ANO - 2013.

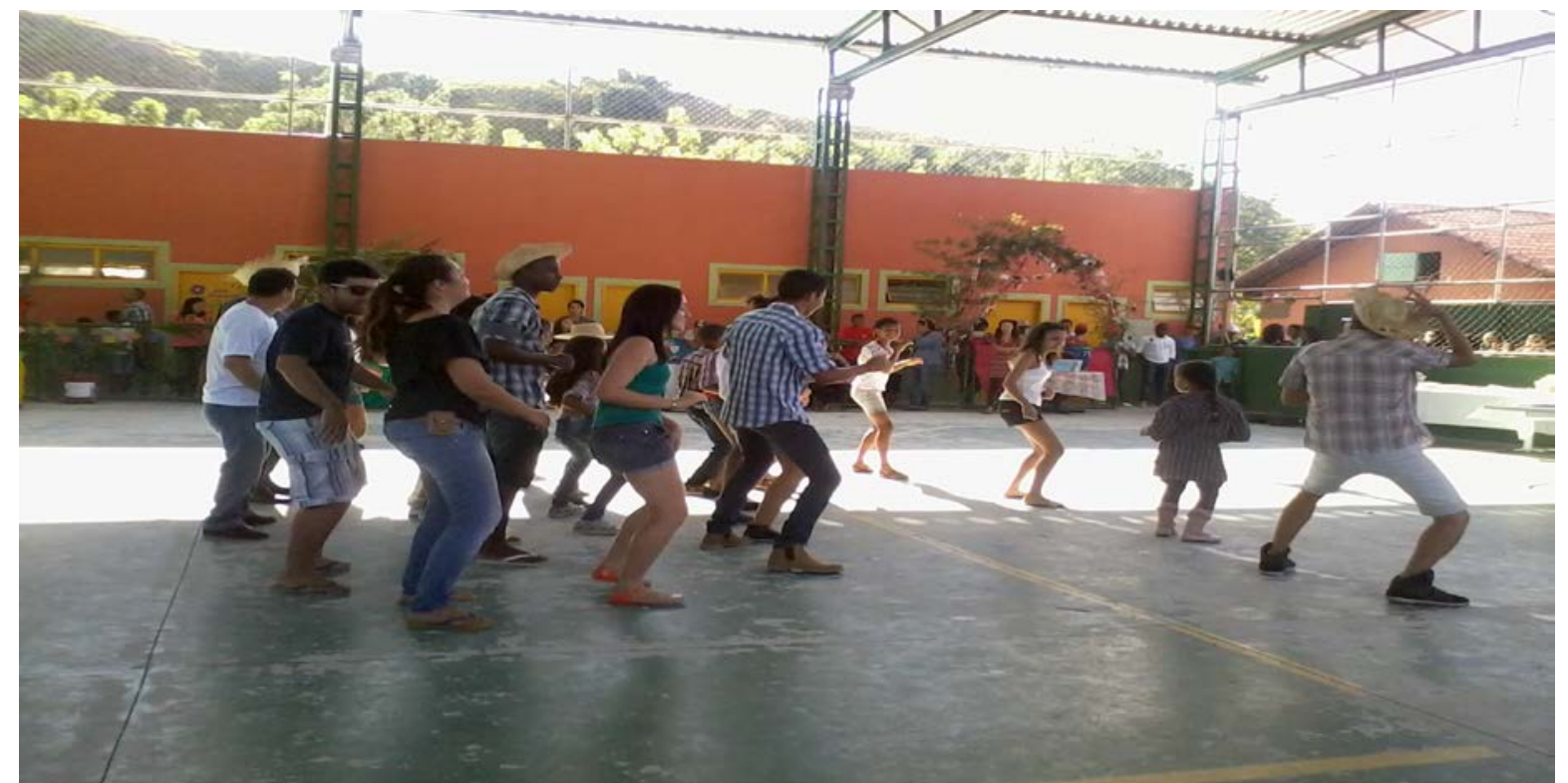

Figura 21 - Dança Caipira Maluca - Festa Junina - ANO - 2013.

A memória na concepção de SILVA (2009, p. 21), pode-se dizer que é responsável pela "conservação" das experiências vividas. Desta forma, a afirmativa que se faz aqui através de um estudo observatório e analisador desta pesquisa, nos leva a "reproduzir” o já vivido; este, todavia, é sempre reinventado, por isso, quando nos lembramos de algo, nos utilizamos de um registro a mais, o da imaginação. Sendo assim, “a memória é essa reserva crescente a cada instante e que dispõe da totalidade da nossa experiência”. Por isso, essa autora afirma que a ponte entre o presente e o passado é feita pela memória. Entretanto, não podemos perder de vista a importância do esquecimento, uma vez que este aponta para os 
silêncios e traumas vivenciados. Nesse caso, pode-se descrever aqui o esquecimento de um acidente em que perdi uma amiga de infância, que ocorreu no dia de meu aniversário de cinco anos, todas as memórias e lembranças que tenho desse fato, são as contadas por quem presenciou o acidente, amigos de minha mãe e de meu pai. Além disso, ao tomarmos consciência de que toda realidade passada é irrecuperável e nunca poderá ser revista como "de fato foi”, somos levados a concluir que o esquecimento é parte integrante da memória e não simplesmente o seu oposto.

Chauí (2000, p. 164) afirma que muitas vezes, as lembranças são tão cruéis, que o melhor será olvidá-las. Para essa autora há um jogo constante entre lembrar e esquecer. Desta forma, ficamos suscetíveis ao esquecimento, quando as lembranças se tornam por demais dolorosas em suas reminiscências: para ela somos capazes de lembrar e recordar. Essas lembranças podem ser trazidas ao presente tanto espontaneamente como por um trabalho deliberado de nossa consciência. Nossas lembranças são espontâneas quando, por exemplo, nos encontramos diante de uma situação presente que nos traz à lembrança de alguma situação passada, esquecida não; mas guardada sim em alguma parte do cérebro que não queria revivê-las. (CHAUÍ 2000, p. 164 in SILVA 2009, p. 21)

Para Le Goff o estudo da memória não é exclusividade da História, pois pertence também a outros campos como o da Antropologia, da Psicologia e da Educação. A memória para ele ganha uma significação particular na História, pois nesta:

“(...) o estudo da memória social é um dos meios fundamentais de abordar os problemas do tempo e da história” (LE GOFF, 1990, p. 426).

Com tudo isso Le Goff (1990) afirma que “(...) hoje, os historiadores se interessam cada vez mais pelas relações entre história e memória”. Mas não se pode deixar de considerar, que, devido a essa dimensão coletiva, a memória ultrapassa as simples lembranças coletadas em entrevistas, ou mesmo os presentes em monumentos, e desta forma ganha status de documento histórico.

SILVA (2009) afirma que: o passado não é a história, porém, um de seus objetos de estudo que é a memória, também não é a história; mas é um dos elementos que contribuem para a elaboração histórica. Tal como as relações entre memória e história, também os diálogos entre passado e presente não são 
estáticos. Sabe-se, hoje, que o passado depende parcialmente do presente. Como já se falou anteriormente, toda história é contemporânea, na medida em que o passado é apreendido pelo presente e responde, portanto, aos seus interesses, o que não só é inevitável, como legítimo.

O passado é, ao mesmo tempo, passado e presente. Logo, a história se tece pela tensão entre o "ontem” - que continua sendo sempre interpretado - e o "hoje".

Na compreensão do passado, devemos, portanto, articular uma leitura renovada, constantemente reconstruída. Assim sendo, podemos inferir que os acontecimentos históricos ocorridos no passado são recriados no presente através da memória. E, partindo desta afirmativa, podemos observar a relevância da correlação entre memória e história.

\section{3}

\section{As Imagens e as suas Finalidades}

Georges Didi-Huberman (2011, p. 3) no texto “Como Levar o mundo nas Costas”, que se insere no âmbito das artes visuais, fala sobre o atlas de imagens, como bem definido: Atlas Mnemosyne, composto por Aby Warburg entre 1924 e 1929, que ficou inacabado, e constitui para qualquer historiador da arte - e para qualquer artista contemporâneo - uma obra de referência e um caso absolutamente fascinante.

Os professores de Artes do C. M. Doutor Aurelino G. Barbosa desenvolvem com os alunos das diferentes séries, desde as séries iniciais até o Ensino Médio, trabalhos de reconhecimento e releitura de diferentes obras de artes, como mostra esses trabalhos que seguem em foto. Essa releitura tem a intenção de ajudar os alunos a desenvolverem seu senso crítico com relação aos seus desenhos, e as suas pinturas, sejam em guache, lápis de cor, canetinha, lápis de cera... Não muito distante dessa mesma intenção, a E. M. Panaro Figueira desenvolve esses mesmos modelos de trabalhos com intenções parecidas, como se pode perceber nas fotos que seguem esse relato. Nas duas escolas esses trabalhos depois são apresentados em eventos internos e externos que englobam o mundo 
das Artes no espaço escolar, mesmo que essas obras sejam amadoras como se pode observar nas fotos que seguem...

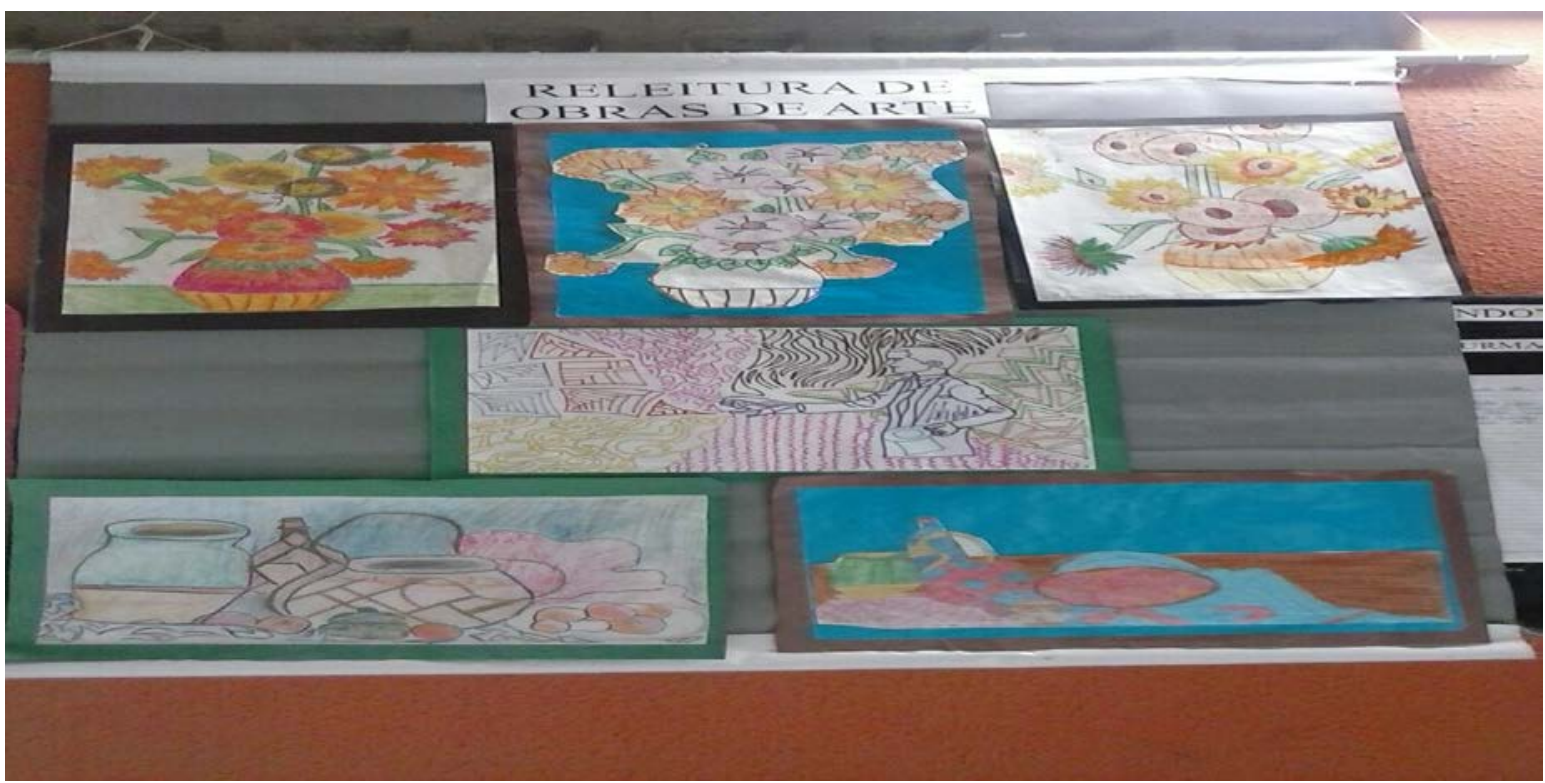

Figura 22 - Releituras em desenhos de obras de Arte confeccionadas por alunos do E. Fundamental II.

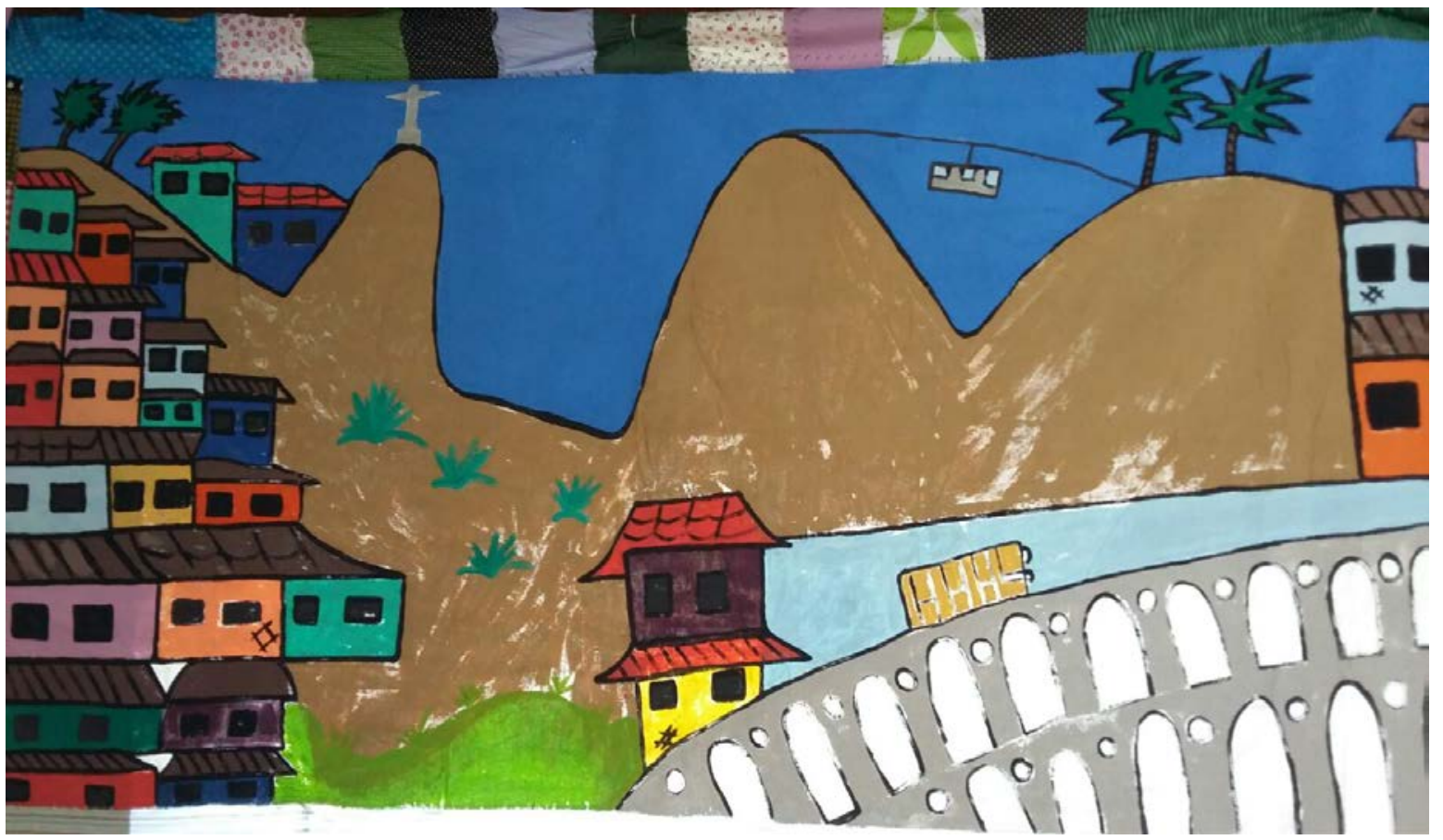

Figura 23 - Painel com imagem do Rio de Janeiro - pintado por um aluno do Ensino Fundamental II do C. M. Doutor Aurelino G. Barbosa. 


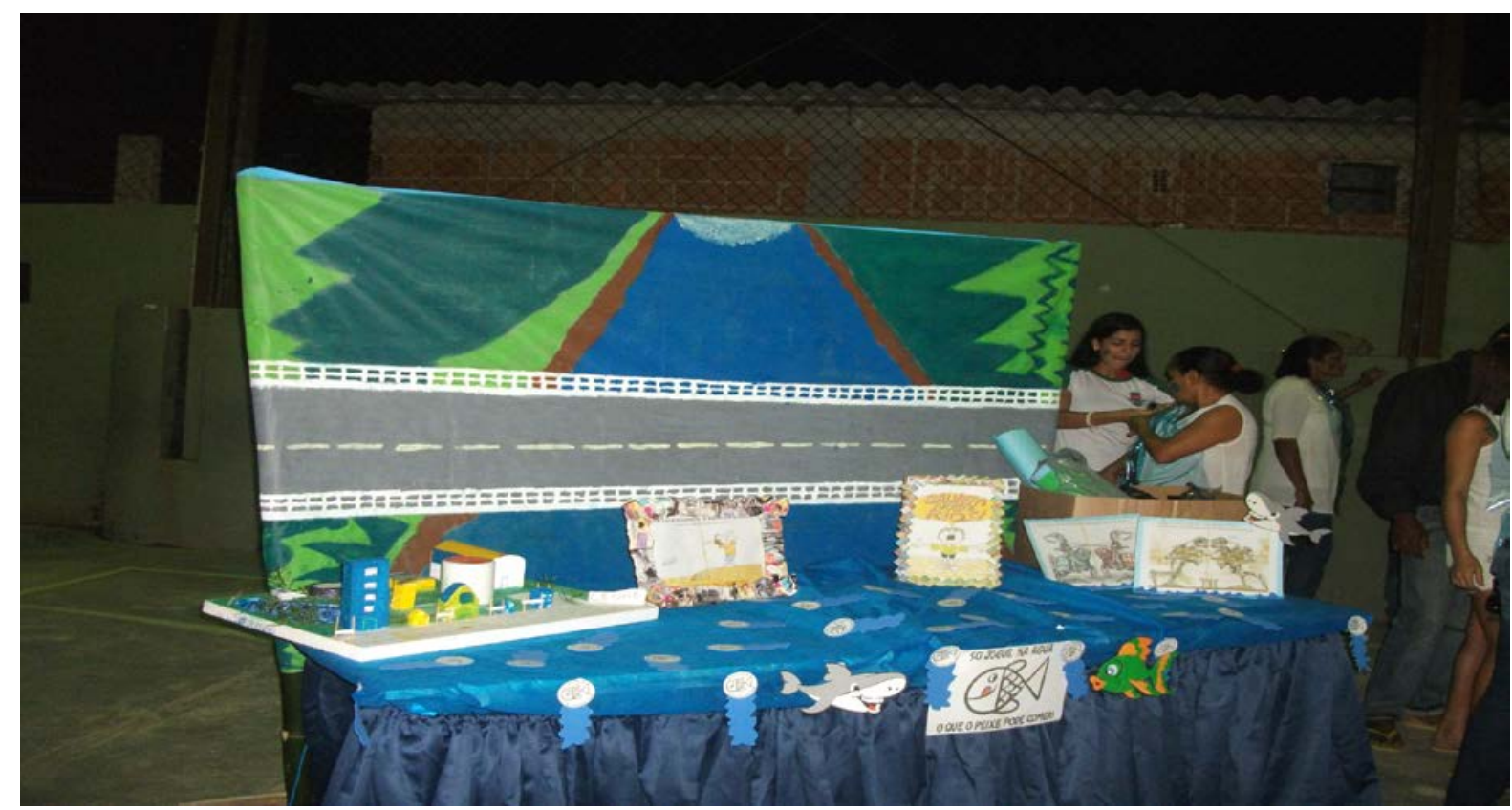

Figura 24 - Desenhos e Makets feitas pela EJA da E. M. Panaro Figueira.

Segundo Didi-Huberman (2011, p. 3):

“Aby Warburg transformou o modo de compreensão das imagens, pois ele é para a história da arte o equivalente ao que Freud, seu contemporâneo, foi para a psicologia: incorporou questões radicalmente novas para a compreensão da arte, e em particular a de memória inconsciente. Mnemosyne tornou-se a sua obra mestra e o seu testamento metodológico, pois reúne todos os objetos da sua investigação num dispositivo de 'painéis móveis' constantemente montados, desmontados, remontados. Aparece também como uma reação de duas experiências profissionais: a da loucura e a da guerra. Pode-se ver então como uma história documental do imaginário ocidental (herdeiro nestes termos de 'Los Desastres de la Guerra' e de 'Los Caprichos' de Goya) e como uma ferramenta para entender a violência política nas imagens da história (comparável nisto ao compêndio de 'Los Desastres de La Guerra')". (WARBURG, ABY in DIDIHUBERMAN, 2011, p. 4)

Segundo Didi-Huberman (2011, p. 5) a obra “Atlas - Como Levar o mundo nas Costas” foi apresentado também como uma exposição interdisciplinar que percorreu o século XX e o recente século XXI, elegendo o atlas de imagens Mnemosyne como ponto de partida. Apesar de todas as diferenças de método e conteúdo que podem separar a investigação de um filósofo-historiador e a produção de um artista visual. Esse trabalho pode fazer com que se fique espantado pelo seu comum método heurístico - ou método experimental - pois, ao se basear numa montagem de imagens heterogêneas. Didi-Huberman (2011, p. 5) afirma que descobriu assim que Warburg partilhou com os artistas do seu tempo uma mesma paixão pela afinidade visual operatória, o que o converteu em 
contemporâneo de artistas plásticos de vanguarda, de fotógrafos de “estilo documental”, de cineastas de vanguarda, de escritores que ensaiavam a montagem literária (Walter Benjamin ou Benjamin Fondane), e inclusive dos poetas e artistas surrealistas.

Didi-Huberman (2011, p. 7) afirma que Warburg concedeu Mnemosyne em termos topográficos, para além da montagem de cartas que forma a prancha preliminar do Atlas, como sugere a enigmática formulação "iconografia dos intervalos”, usada pelo historiador da arte em seu diário em 1929. Isso é uma iconologia que se referia não à significação das figuras - foi esse o sentido que lhe deu Panofsky -, mas as relações mantidas por essas figuras entre si numa disposição visual autônoma, irredutível à ordem do discurso. Na Gênese de Mnemosyne, constata-se que o Atlas recapitula em imagens as pesquisas conduzidas por Warburg ao longo de toda a sua carreira.

Já as imagens e os desenhos que são desenvolvidas no espaço escolar como aparato para os trabalhos em Artes, na maioria das vezes retratam as vivências dos alunos, os seus dons artísticos... Estimulando dessa forma na maioria das vezes, os seus modos de entender e interpretar o mundo através das imagens.

\section{4}

\section{As Imagens como perpetuação do tempo e da história}

Aqui me reporto à descrição das imagens do encerramento de conclusão de curso das turmas da Educação de Jovens e Adultos, do $9^{\circ}$ ano do Ensino Fundamental e do $3^{\circ}$ ano do Ensino Médio, pois essas imagens fotográficas são para essa dissertação, o arcabouço principal da construção memorialística dos fatos passados, vividos por todos que fazem parte da construção dessas escritas que estão representadas através de imagens e fotos...

Inicio aqui com três momentos bem diferentes de um evento que se tornou a marca registrada dessas duas escolas com o incentivo dos professores diretores e de toda a comunidade escolar para que essa se efetive: a festa de conclusão do $9^{\circ}$ ano do Ensino Fundamental, do Ensino Médio e da Educação de Jovens e Adultos que acaba se tornando o trampolim para muitos desses alunos, que retornaram a 
escola em busca de seus diplomas de conclusão, para darem continuidade a seus estudos interrompidos por motivos diversos e adversos às suas vontades...

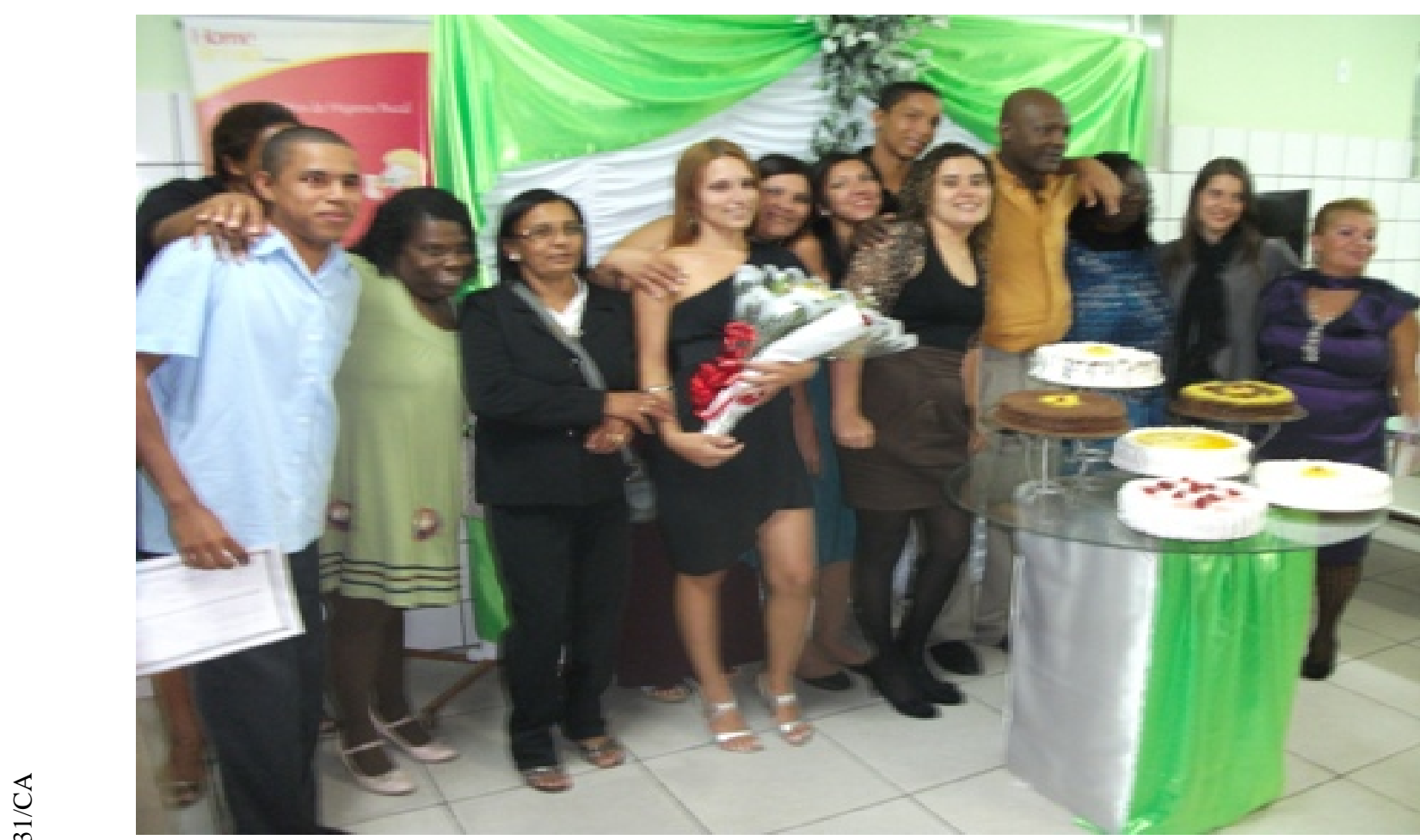

Figura 25 - Formatura da EJA Escola Municipal Panaro Figueira - 2010.

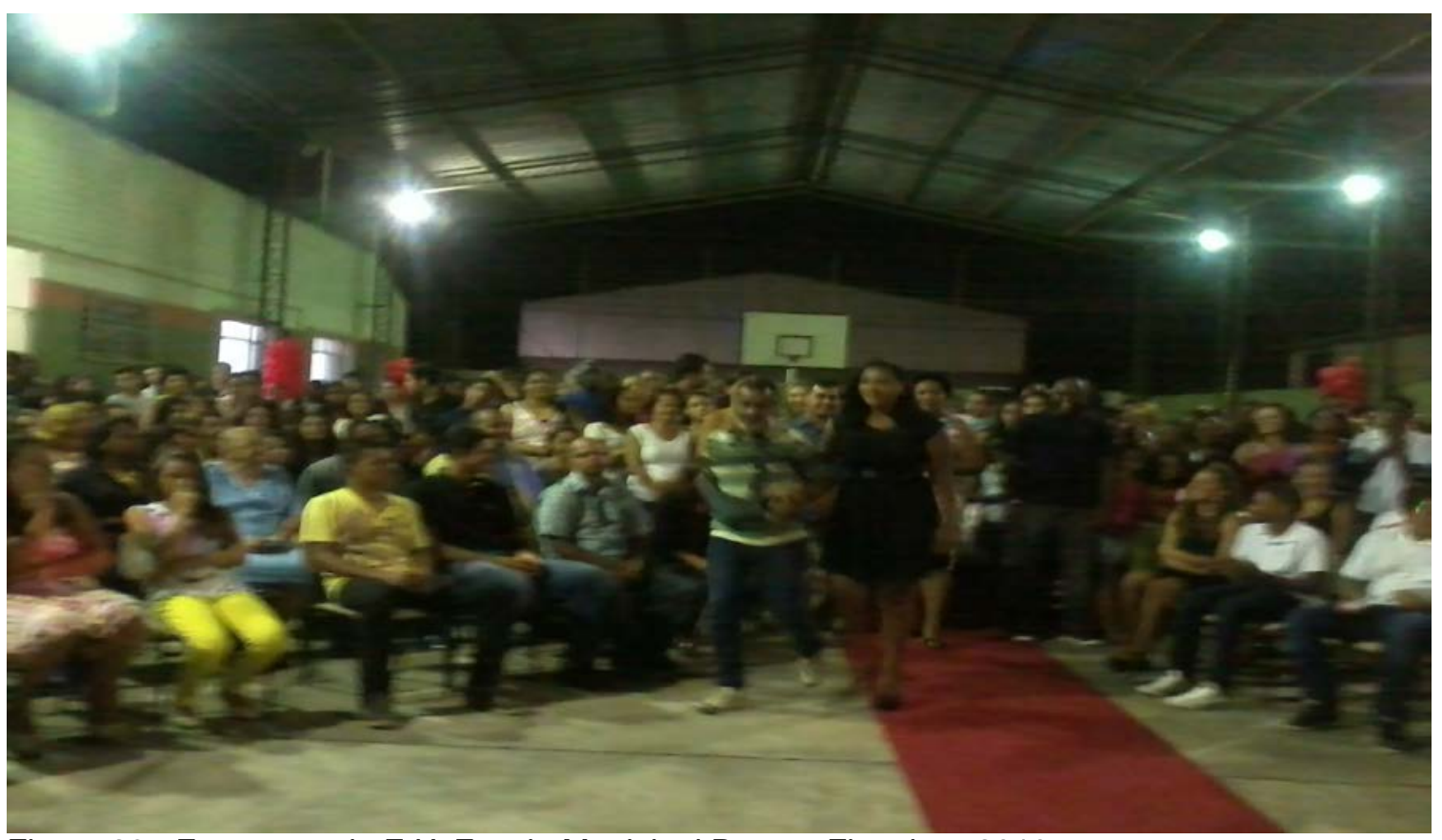

Figura 26 - Formatura da EJA Escola Municipal Panaro Figueira - 2010. 


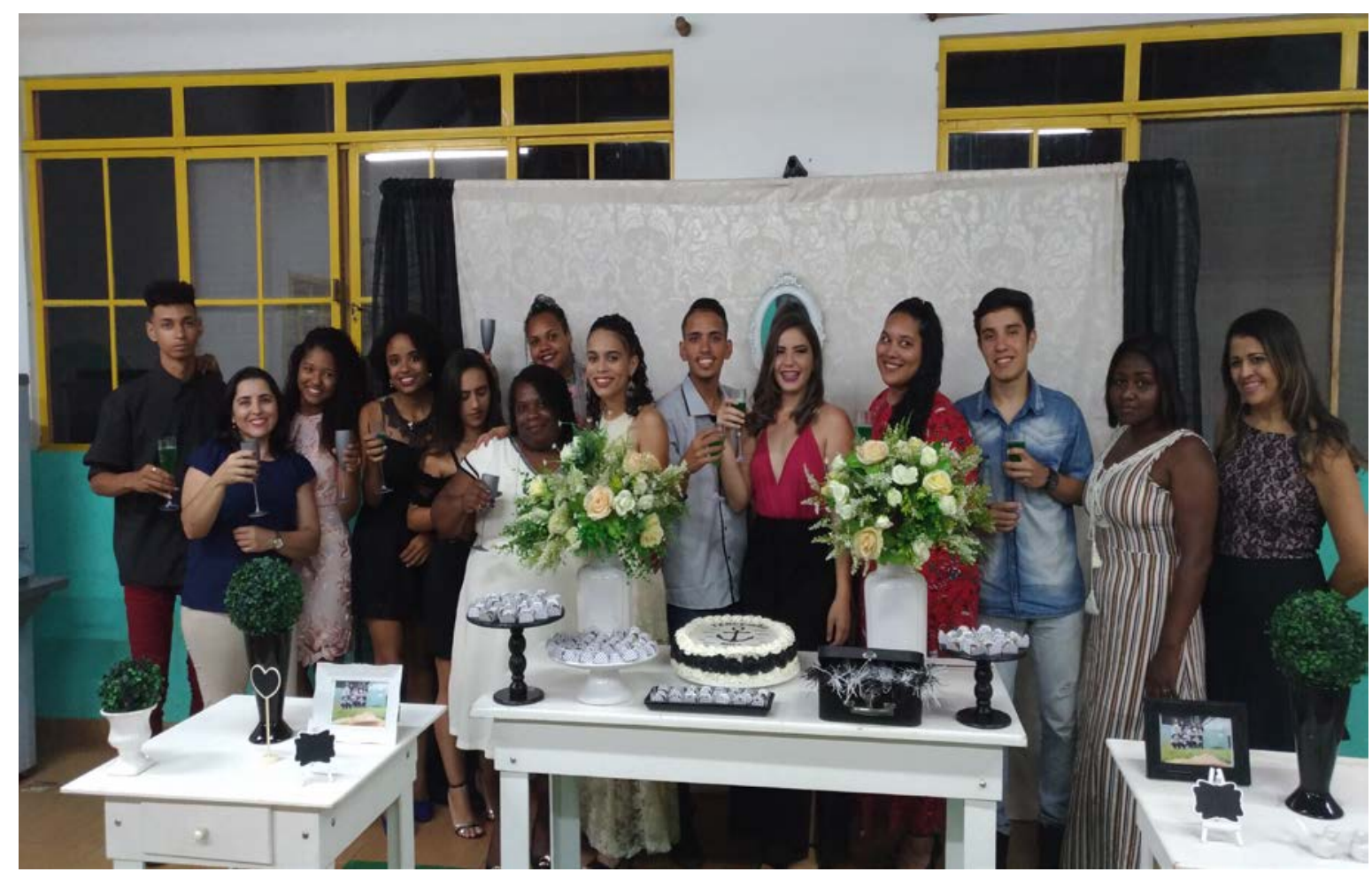

Figura 27 - Formatura da EJA e do Ensino Médio do C. M. Doutor Aurelino G. Barbosa 2017.

As imagens contextualizadas acima, são reveladoras do que se passa em um momento como esse para pais, alunos, professores, familiares... E todos que se inserem nesse contexto. A memória jamais deixa apagar o momento cristalizado pela fotografia, a fotografia traz de volta as recordações, as emoções, os sentimentos, as alegrias, as tristezas... Esses momentos são reconhecidos como “ritos de passagem”, os ritos de passagens às vezes nos levam muito além do que esperamos... O que dizer do tempo, esse nunca retorna ao ponto de partida, ele apenas é preservado pela criação do homem de objetos que fizeram com que esse se perpetuasse, assim pode-se observar que tudo que hoje se encontra preservado na história, fez-se pela ação do homem em seu processo de criação. Mas esse mesmo homem que cria, é capaz também de ajudar a destruir por ações que ele com consciência ou não, influencia a ação da natureza.

\section{5}

\section{A Imagem transpondo o tempo}

Didi Huberman (2014, p.1) em sua obra "Diante do tempo" nos leva a compreensão de que: 


\begin{abstract}
“Quando nos encontramos 'Diante de uma imagem', estamos sempre diante do tempo; esse tempo é cristalizado nessa imagem e ele não nos esconde nada, para isso bastaria entrar nela; sua luz perpetua o acontecimento através do tempo e esse quase nos cega, por isso ela nos impõe respeito. Por sua abertura como uma guardiã nos faz parar: olhá-la, observá-la e admirá-la desejando, estar à espera de algo, estar diante do tempo". (DIDI HUBERMAN 2014, p.1)
\end{abstract}

Didi Huberman (2014, p.2), nos conduz ao painel de pintura renascentista que se apresentou na imagem descrita por ele, é um afresco que no corredor oriental da clausura, se encontra à altura do olhar. Esse olhar pode ser um olhar mais técnico e preciso, ou este olhar pode ser um olhar mais brando e admirador. Nesta dupla diferença Didi-Huberman (2014, p. 2) afirma que:

- "a cena figurada em cima, o fundo branco todo em volta -, o painel de afresco vermelho, crivado de manchas erráticas, produz como uma deflagração: um fogo de artifício colorido que ainda traz o traço de seu jorrar originário (em um naco de instante, o pigmento foi projetado à distância, em chuva) e que, a partir de então, se perpetuou como uma constelação de estrelas fixas”. (DIDIHUBERMAN, 2014, p. 2),

\title{
Para Didi-Huberman (2014, p. 2), diante desta imagem,
} intempestivamente, o presente pode se ver tragado e, simultaneamente, trazido à luz na experiência do olhar. Mesmo que para isso muitos anos tenham se passado desde a experiência singular, o "presente com suas reminiscências” parece não ter terminado de tirar dela todas as lições. Diante de uma imagem - não importa quão antiga essa seja -, o presente não cessa jamais de se reconfigurar.

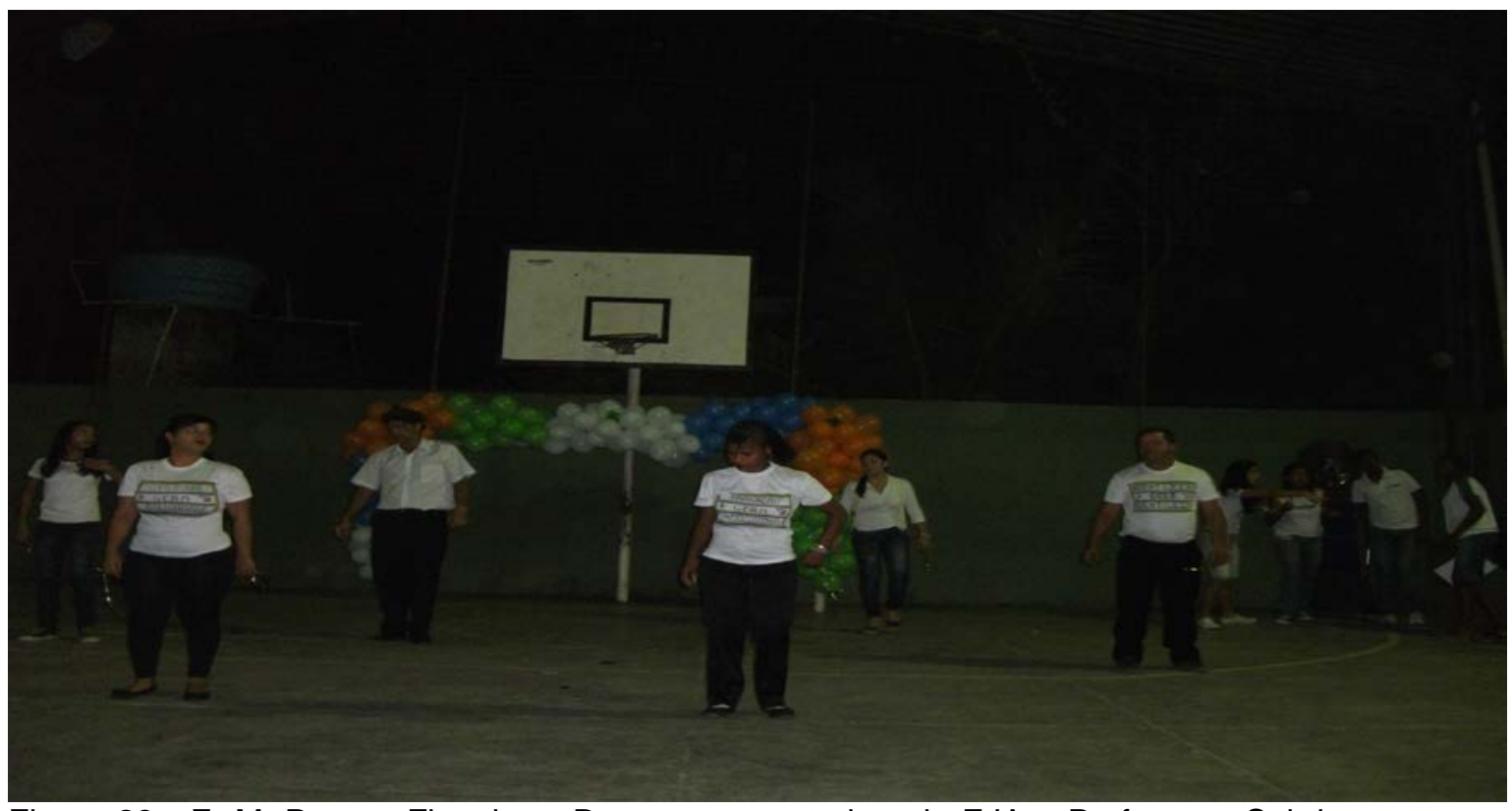

Figura 28 - E. M. Panaro Figueira - Dança apresentada pela EJA - Professora Sabrina (Educação Física). 


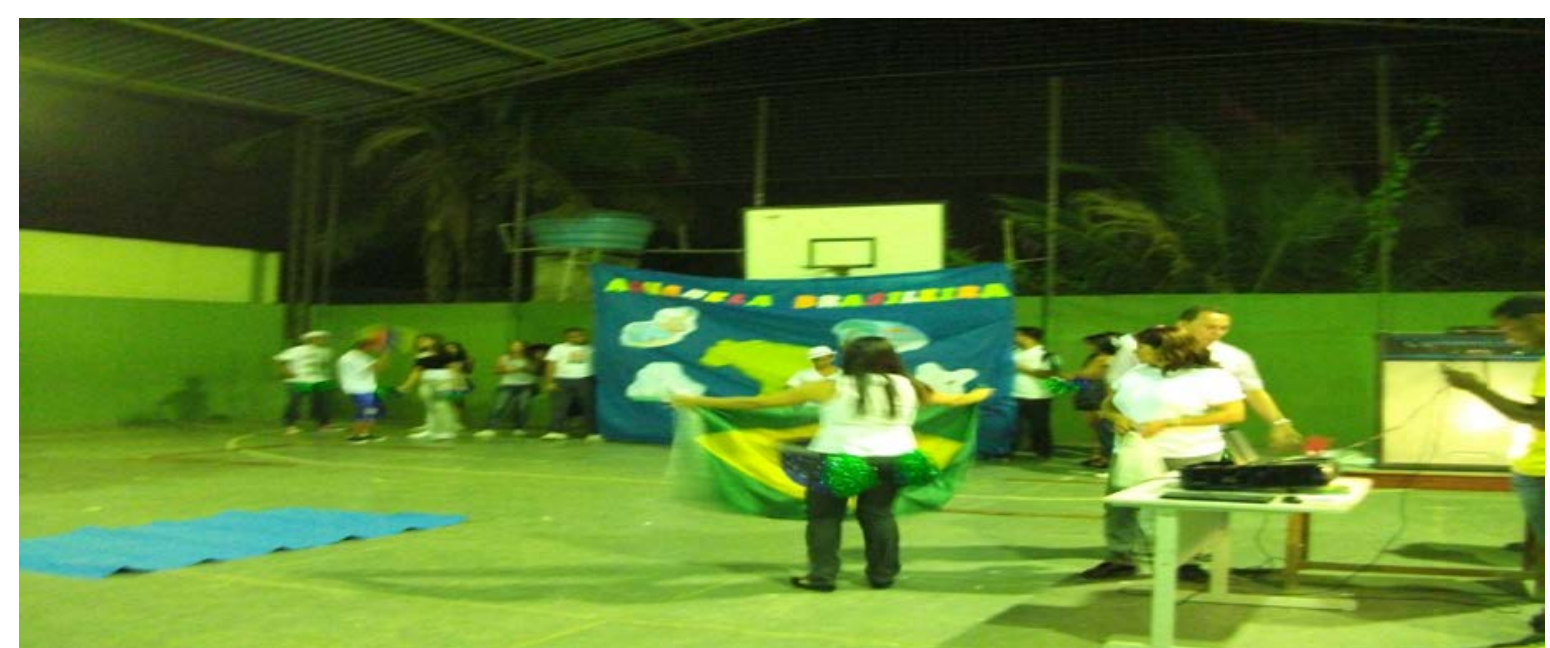

Figura 29 - E.M. Panaro Figueira - preparação para apresentação da música Aquarela do Brasil.

Didi Huberman (2014, p. 3) afirma que:

"Diante de uma imagem - não importa quão recente, quão contemporânea ela seja -, o passado também não cessa jamais, pois esta imagem não se torna pensável senão em uma construção da memória, chegando ao ponto de uma obsessão. Para ele o estar diante de uma imagem, nos faz perder como seres humanos as vicissitudes da vida, podemos perder também para a imagem a cristalização do tempo, pois a imagem guarda o tempo em si mesmo, e para nós "seres humanos" a vida se vai e ficam as lembranças que sobreviverão a nós, diante dela, nós somos o elemento frágil, o elemento passageiro, e, diante de nós, ela é o elemento do futuro, o elemento da duração". (DIDI HUBERMAN 2014, p. 3)

Para Didi-Huberman (2014, p.11) “uma imagem tem mais memória e mais porvir do que o ente que a olha”. Enquanto seres humanos nos mantemos a altura de todos os tempos, pois foi através da imagem que se conseguiu perpetuar esse tempo, seja através de pinturas, quadros, fotos, obras de arte; e essa imagem conjuga sobre tantos planos, diante de nós, e fica presente nesta experiência, da memória...

Didi-Huberman (2014, p.11) afirma que o historiador parece constituir a evidência das evidências: a recusa do anacronismo; não um anacronismo para aquele tempo, mas sim para além do tempo. A regra de ouro não seria apenas “projetar” nossas próprias realidades sobre as realidades do passado. Não se pode afirmar que seja uma evidência, que a "chave” para compreender um objeto do passado se encontra no próprio passado e, ainda mais, no mesmo passado que o passado do objeto. 


\section{6}

\section{A Imagem sobrevivente e a dupla distância}

Didi -Huberman (2014, p.25) nos apresenta 'A Imagem Sobrevivente’ em 'Warburg, nosso fantasma' como “uma imagem de despedaçamento humano, passional, violento, cristalizado em seu momento de intensidade física”.

Ao pensar nessa imagem descrita por Warburg, vem a lembrança dos alunos perdidos em mortes brutais por estarem envolvidos no tráfico, em roubos, em milícias... É difícil para nós professores convivermos com isso e não podermos fazer nada, pois se tentamos resgatar esses alunos, muitas das vezes somos ameaçados. Recordo-me bem de um momento em minha vida como professora que comecei a fazer um trabalho em uma das escolas que trabalhei e que fui diretora, dando palestras contra droga. Recebi uma ameaça velada de um traficante que usou comigo uma fala que me marcou muito "professora, a senhora é uma pessoa tão bacana, mas está atrapalhando meus negócios”. Aquilo para mim soou como uma bomba, pois ao tentar tirar meus alunos que estavam se envolvendo no mundo das drogas, coloquei a minha vida em risco. Tenho certeza que o tráfico não fez nada comigo, por eu ser uma pessoa que converso com qualquer pessoa. No decorrer desse período vimos muitos desses alunos morrerem, alguns os pais nem o corpo para enterrar tiveram, pois simplesmente os corpos sumiram... Tivemos em outra escola duas alunas que saíram de casa para irem à escola em uma sexta-feira, quando foi na segunda-feira seguinte, as mães estavam na escola procurando, pois elas não haviam voltado para casa... Naquela mesma semana seus corpos foram encontrados sem cabeça boiando em um rio... Um horror que muitas famílias de periferia passam, por não conseguirem controlar seus filhos, pois esses se encantam com o dinheiro fácil que o tráfico, os assaltos e a milícia oferecem para eles serem seus soldados, "soldados da contravenção”. São lembranças muito triste que ainda assombram a minha vida. São muitas dessas passagens que ainda me fazem investir na educação em busca de fazê-los nos verem enquanto professor como modelos de vida, pois a maioria deseja ser como nós, apesar de um professor não ganhar um salário dos sonhos, mais ainda servem de exemplos para muitos desses alunos, perdidos em 
famílias desestruturadas... “Quantas vidas já salvamos, quantas vidas já transformamos através da educação”...

A concepção de Didi Huberman (2014, p. 25):

"Warburg substituiu o modelo natural dos ciclos de 'vida e morte', 'grandeza e decadência', por um modelo decididamente não natural e simbólico, um modelo cultural da história, no qual os tempos já não eram calcados em estágios biomórficos, mas se exprimiam por estratos, blocos híbridos, rizomas, complexidades especificas, retornos frequentemente inesperados e objetivos sempre frustrados. Para esse autor Warburg substituiu o modelo ideal das renascenças, das boas imitações e das 'serenas belezas' antigas por um modelo fantasmal da história, no qual o tempo já não se calcava na transmissão acadêmica dos saberes, mas exprimiam por obsessões, 'sobrevivências', remanências, reaparições das formas. Ou seja por não saberes, por irreflexões, por inconscientes do tempo". (DIDI-HUBERMAN 2014, p.25)

Aqui falo das vivências que os alunos adquirem em seus passeios culturais, somando-as as vivências pessoais que eles trazem consigo e utilizam como troca de experiências para a sua vida, os trabalhos desenvolvidos por eles normalmente estão em consonância com o ambiente, percebe-se que há um trabalho específico que pauta-se na teoria da evolução moderna conquistada através do conhecimento adquirido.

Toda imagem apresentada como imagem sobrevivente para o mundo da arte que não estava acostumado a este tipo de imagem Warburg decompôs. Ele desconstruiu sub-repticiamente todos os modelos epistêmicos em uso na história da arte vasariana e Winckelmanniana. Warburg desconstruiu o que a atual história da arte ainda toma por seu momento iniciativo. Posso retomar aqui a um passeio turístico que levou os alunos a percorrer a história do Brasil em seu processo de emancipação, em uma parceria com o professor de História Geraldo Miguel (in memorian)... Em nosso projeto de incentivo a leitura e a escrita percorremos Petrópolis várias vezes com os nossos alunos em busca da história da história; pois a construção de saberes a partir da história legítima que são as suas vivências faz com que nossos alunos vivam a história de forma diferente. Faz com que eles conheçam como se deu essa construção. Nesse momento eu me reporto ao que nós vemos e o que nos olha. O olhar para história a partir de um quadro e sua imagem, traz para nossa imaginação as recordações do que o livro de história nos conta... Pode-se observar isso na fotografia do quadro que segue... 


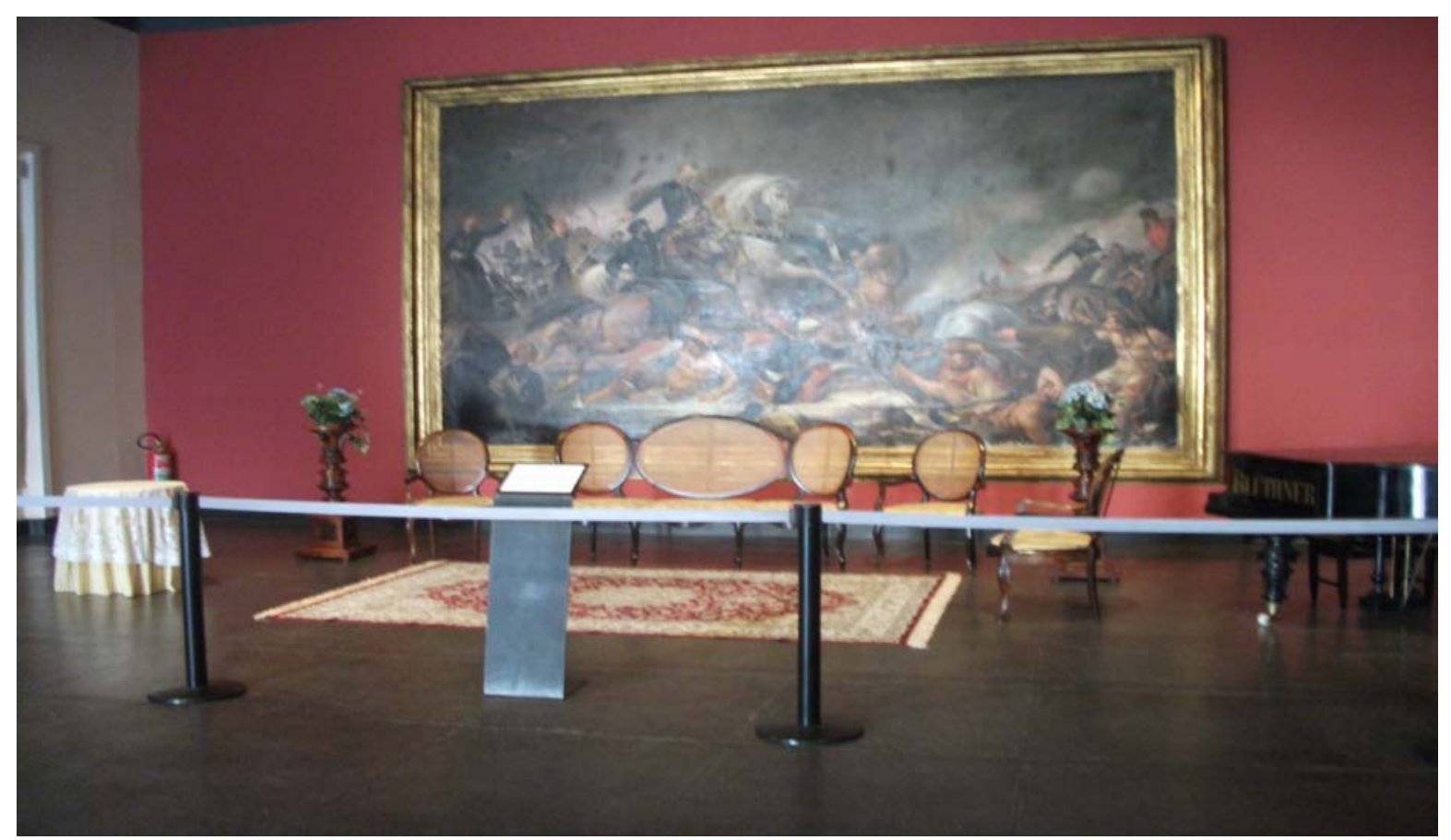

Figura 30 - Quadro do museu de Petrópolis batalha da Independência.

Os dois momentos descritos por mim acima demonstram fatos bem diferentes, em um a tristeza faz morada, no outro a alegria enobrece a alma, faz crescer, ensina a viver... Assim é o mundo da arte, há fatos que denotam a beleza do mundo, outros denotam fatos tristes, e mostram as tragédias da vida...

Para Didi-Huberman (2014, p. 26), com Warburg:

“A ideia de arte e a ideia de história passaram por uma reviravolta decisiva. Depois dele, já não se esta diante da imagem e diante do tempo, como antes. Todavia, a história da arte com ele não começa, no sentido de uma refundação sistemática que talvez tivéssemos o direito de esperar. Com ele, a história da arte se inquieta sem cessar, a história da arte se perturba, esse fato nos reporta a lembranças da lição benjaminiana, que nos leva ao toque da origem. A história da arte segundo Warburg é justamente o contrário de um começo absoluto, de uma tabula rasa: é, antes de tudo um turbilhão no rio da disciplina, um turbilhão - um momento-agitador - depois do qual o curso das coisas se haverá desviado profundamente, ou até se transtornado”. DIDI-HUBERMAN (2014, p. 26)

Didi-Huberman (2015, p. 147), em "O que vemos o que nos olha”, nos leva “A dupla Distância” de uma imagem, momento este em que Walter

Benjamim nos legou: a aura:

"Uma trama singular de espaço e de tempo", ou seja, um espaçamento tramado e mesmo trabalhado, poder-se-ia dizer: um espaçamento tramado em todos os sentidos do termo, como um sutil tecido ou então como um acontecimento único, estranho (sonderbar), que nos cercaria, nos pegaria, nos prenderia em sua rede. E acabaria por dar origem, a essa coisa trabalhada ou a esse ataque da visibilidade, a algo como uma metamorfose visual específica que emerge desse tecido mesmo, 
desse casulo - outro sentido da palavra Gespinst - de espaço e de tempo. A aura seria como um espaçamento tramado do olhante e do olhado, do olhante pelo olhado. Um paradigma visual que Benjamin apresentava antes de tudo como um poder da distância: "Única aparição de uma coisa longínqua, por mais próxima que possa estar”. (DIDI-HUBERMAN 2015, p. 147).

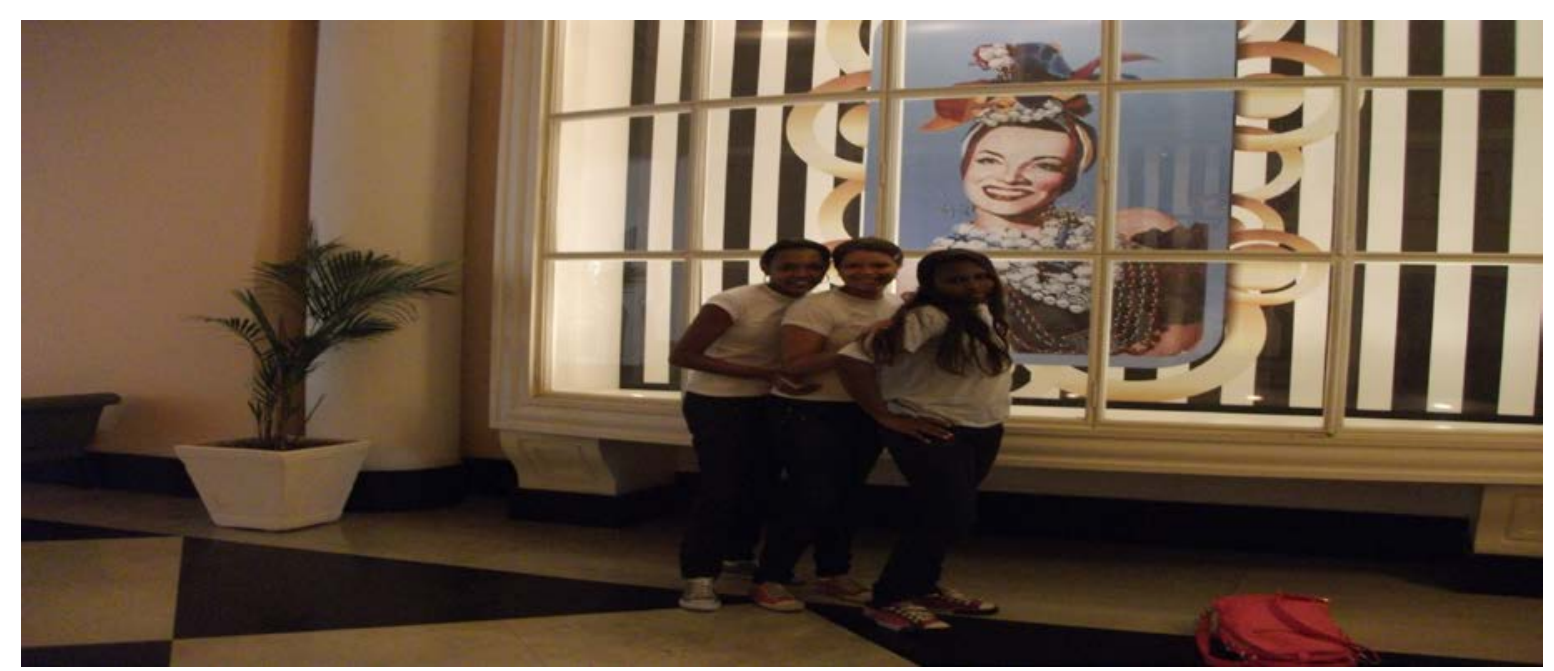

Figura 31 - Quadro de Carmem Miranda em um momento glorioso da sua vida - Museu de Petrópolis.

Segundo Didi-Huberman (2015, p.148) na obra "O que vemos e o que nos olha” ao falar de Walter Benjamin, ele nos leva a um paradigma visual que se apresenta como um poder da distância. Nesse contexto "a distância aparece no acontecimento da aura, como uma distância já desdobrada. Esse dom de visibilidade, Benjamin insiste que essa permanecerá sob a autoridade da lonjura, que só se mostra ali para se mostrar distante, ainda e sempre, por mais próxima que seja essa aparição” (DIDI-HUBERMAN 2015, p.148). 


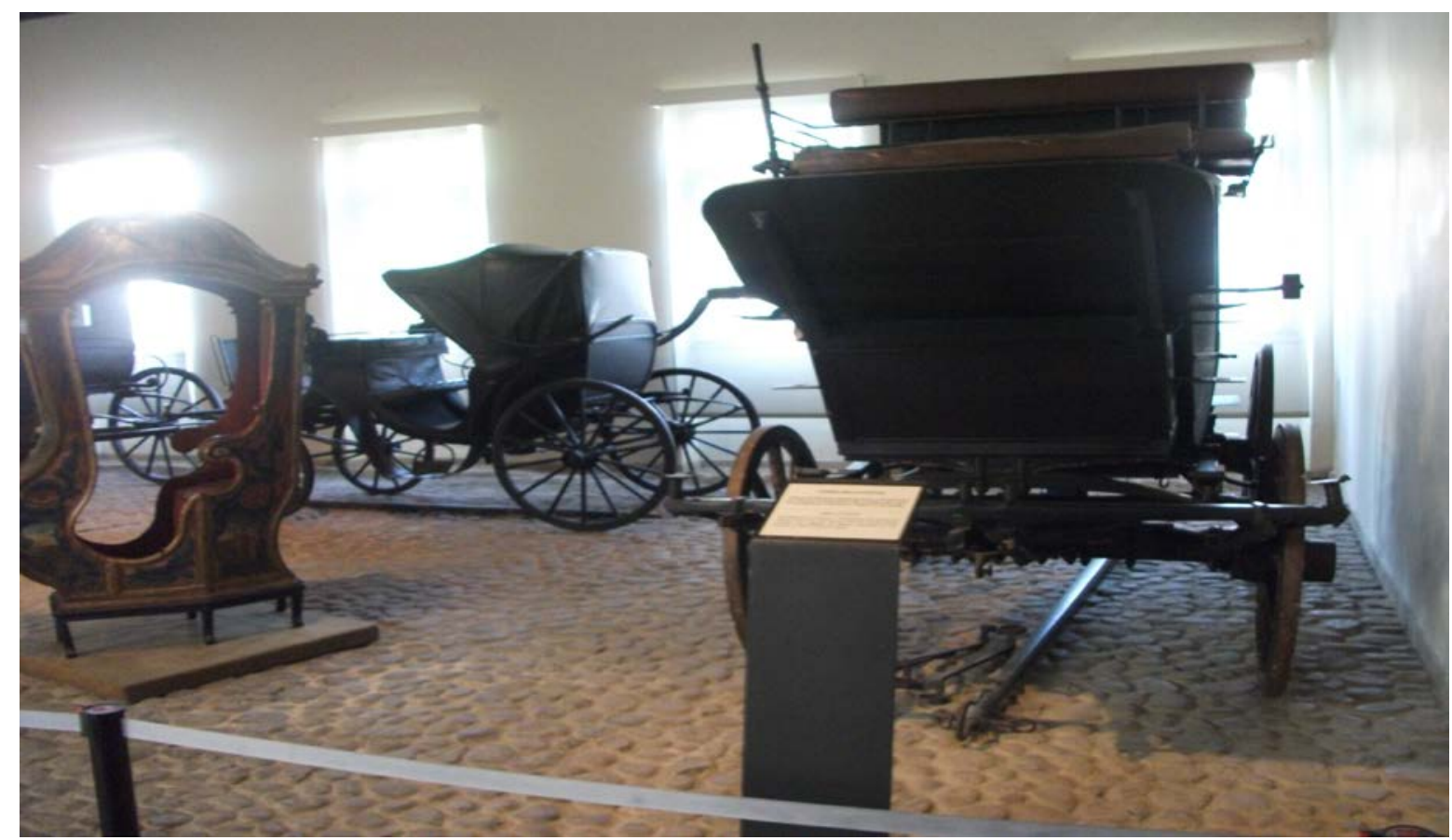

Figura 32 - Foto das carruagens antigas no Museu de Petrópolis.

No paradigma apresentado por Benjamin, o objeto aurático supõe assim uma forma de heurística na qual a distância - as distâncias contraditórias das vivências descritas - se experimentaria uma às outras, dialeticamente. O próprio objeto tornando-se, nessa operação, o índice de uma perda que ele sustenta, e que opera visualmente: apresentando-se, aproximando-se, mas produzindo essa aproximação como o momento experimentado “único” (einmalig) e totalmente “estranho” (sonderbar) de um soberano distanciamento, de uma soberana estranheza ou de uma extravagância. Uma obra da ausência que vai e vem, sob os nossos olhos e fora de nossa visão, uma obra anadiômena da ausência. (WALTER BENJAMIN, in DIDI-HUBERMAN, 2015, p. 148)

Para Didi-Huberman (2015, p. 148) em “O que Vemos e o que nos Olha”:

"Sob nossos olhos, fora de nossa visão: algo aqui nos fala tanto do assédio como do que nos acudiria de longe, nos concerniria, nos olharia e nos escaparia ao mesmo tempo. É a partir de tal paradoxo que devemos certamente compreender o segundo aspecto da aura; que é o de um poder do olhar atribuído ao próprio olhado pelo olhante: isto me olha. Aqui finalmente se toca o caráter evidentemente fantasmático dessa experiência, mas, antes de buscar avaliar seu teor simplesmente ilusório ou, ao contrário, seu eventual teor de verdade, retenhase assim a fórmula pela qual Benjamin explica essa experiência: Sentir a aura de uma coisa é conferir-lhe o poder de levantar os olhos", para ele "Esta é uma das fontes mesmas da poesia”. DIDI-HUBERMAN ( 2015, p. 148) 


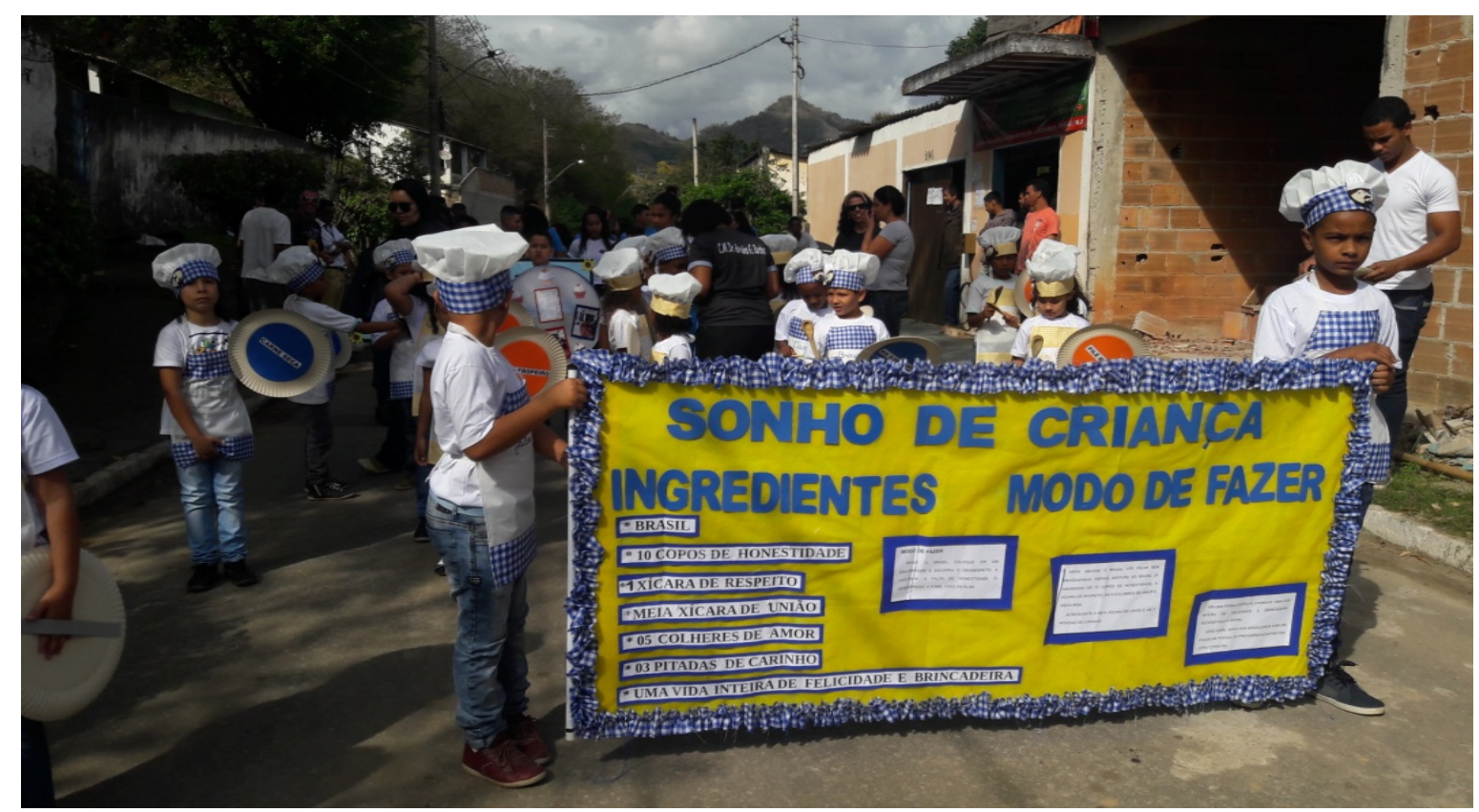

Figura 33 - Foto de um desfile cívico em que as crianças carregam consigo uma lista de ingredientes para realizar um sonho de criança, isso é poesia para os olhos...

Segundo Didi-Huberman (2015, p. 149-150), para Benjamin, a aura não poderia se reduzir a uma pura e simples fenomenologia da fascinação alienada que tende para a alucinação. Seria sim, um olhar trabalhado pelo tempo, um olhar que deixaria a aparição no tempo se desdobrar como pensamento, ou seja, que deixaria ao espaço o tempo de se retramar de outro modo, de se reconverter em tempo. Assim surge o sonho de uma criança, para que uma criança tenha um sonho faz-se necessário que se permita a ela viver a sua infância de uma forma que lhe permita sonhar, pois a criança que não lhe é dada a oportunidade de ter uma infância, jamais conseguirá saber o que é o sonho, o que é a ação verbal do sonhar... Nessa distância que nos olha e nos toca, como afirma Benjamin se pode reconhecer ainda - e de maneira indissociável a tudo o que precede - o poder da memória. Esse fato Benjamin apresenta, em seu texto sobre os motivos baudelarianos, sob a espécie da “memória voluntária”. Para Benjamin, essa memória, é claro, está para o tempo linear assim como a visualidade aurática para a visibilidade “objetiva”, ou seja, todos os tempos nela serão trançados, feitos e desfeitos, contraditos e supramencionados. É nesse contexto que aparece 'o paradigma do sonho', que Benjamin apoia - além de Baudelaire - nas figuras de Proust e de Paul Valéry. Quando define a aura da percepção do sonho, Valéry propõe uma ideia análoga, mas que vai mais longe, sua orientação a esse respeito é objetiva. 
Para Didi-Huberman (2015, p. 150), entrelaçam-se na aura, a onipotência do olhar e a de uma memória que se percorre como quem se perde numa "floresta de símbolos”. Como negar, com efeito, que é o tesouro do simbólico - sua arborescência estrutural, sua historicidade complexa sempre relembrada, sempre transformada - que nos olha em cada forma visível investida desse poder de "levantar os olhos" e ver. 


\section{As Práticas pedagógicas através de projetos}

Ao inserir-me na Educação através de um concurso público após os anos de formação no Curso de Letras, especificamente em Língua Portuguesa e Língua Inglesa. Pude perceber que a Educação que buscava não era aquela conteudista que ali se apresentava. A quantidade de conteúdos que consideravam básicos tornava muito difícil frente a uma instituição escolar ensinar algo que fosse além do considerado mínimo ou básico. Quando enquanto professores, montávamos esses ditos conteúdos básicos, sentia que estava faltando algo que desse vida a aprendizagem. Ao serem aprovados esses conteúdos básicos comuns, ao invés de direcioná-los para uma flexibilidade que fosse de acordo com a realidade da comunidade a qual este seria inserido, dando ao docente a oportunidade de planejar a partir de seus próprios planos curriculares, esses eram enviados a Secretaria de Educação para tornarem-se documentos imbatíveis. Cabia ali mudar aquele quadro, a princípio seguia a risca o que ali exigiam, a reprovação era o carro chefe que comandava essa linha conteudista. A ideia de mudar esse quadro passou a fazer parte do ideal de aprendizagem que queria para aqueles alunos que a nossa frente se encontravam. Surgiu ali, ainda em um período bem rigoroso da Educação tradicional, um viés educativo que mais a frente pude perceber que se tornou a marca registrada do ser educador.

Segundo Ribas (2017, p. 15):

"Quando estamos entediados, enquadramos tudo no modo déjà vu; e não temos o olhar interessado, curioso, aquilo que nos permite encontrar novidades no banal, singularidade no plural, criatividade no massivo, diferença na repetição. Então, nos perguntamos o que fazer? Vale lembrar que essa indagação é uma prática amadurecida [...] Ora, sabemos que procurar algo "novo" não significa elaborar algo que alguém jamais fez - isso é reincidir no mito da originalidade.”

O que nós professores fazíamos desde a década de 1990 talvez não fosse original, mas mudou a minha forma de olhar enquanto professora para a Educação, esses trabalhos se intensificaram a partir do ano 2000. Hoje sei que o nome que se deu a essas diferentes abordagens educativas, diversificadas e diferenciadas chama-se "Projeto” são esses projetos que fizeram com que pudesse 
mudar a história de muitos alunos, desde o Antigo primeiro grau, hoje Ensino Fundamental até o Ensino Médio (antigo segundo grau).

Ver alunos florescerem com a diversidade de atividades extraclasse que montávamos com eles próprios era uma dádiva... Danças, Feiras Culturais, Passeios Turísticos ou mesmo direcionados, Visitação a Museus, Cidades Históricas, Parques, Bienal...

Essas eram práticas educativas inovadoras na década de 1990 a 2000, e ainda o são atualmente, pois se sabe que as dificuldades financeiras atingiam e ainda atingem - em cheio as escolas públicas periféricas, muitas das vezes por serem mal administradas pelo setor público, ao qual ela se encontra ligadas. A pobreza é visível nas feições, nas roupas de alguns desses alunos... Os trabalhos que vêm descritos e apresentados abaixo nos levaram a uma viagem pelo processo criador que envolve, talvez ainda de forma inacreditável algumas escolas da Baixada Fluminense e também do Médio Paraíba. Essas Escolas podem ser consideradas ‘escolas vivas’.

Vivas sim, porque a criatividade praticada nelas vem desde a Educação Infantil, Ensino Fundamental, Educação de Jovens e Adultos e Ensino Médio... Há um trabalho 'Interdisciplinar' que faz com que esses eventos aconteçam; há uma necessidade de comprometimento por parte dos professores, alunos, pais de alunos, funcionários... Todos são peças essenciais para que tudo dê certo...

Porque, é a partir daí que a maioria dos alunos que passaram e passam por essas escolas tem histórias de fracasso, de sucesso e de superação que os levam a alcançar um nível de aprendizagem cristalizado, elevando assim o hoje conhecido IDEB do município nos quais esses alunos, e essas escolas encontram-se inseridos. Esses acontecimentos tiveram início em 1992, com passeios em outras escolas que não cabem aqui nessa pesquisa...

Surge ai a cristalização do tempo através das Imagens... Todos esses eventos foram registrados em fotos, tornaram-se Memórias Vivas de acontecimentos que até hoje trazem o seu ineditismo. Porque naquela época, conseguir que um pai permitisse que seus filhos, que nunca haviam saído de seu local de habitação, fossem a passeios com professores era muito difícil. Tinha de haver confiança, começamos a fazer reuniões de pais para pedir essas autorizações, criamos ali um elo entre família e escola que se tornou uma parceria 
de sucesso... Hoje é tudo mais fácil. Naquela época, muitos de nossos alunos não tinham às vezes nem comida em casa. Iam para a escola para estudar, e para matar a fome... Muitas vezes entravamos em contato com o poder público de Piraí ou de Seropédica, ou mesmo de outros lugares que eram amigos e solicitávamos doações para realizarmos algumas das ações e eventos almejados. Pedíamos ônibus, lanches, doações... Tínhamos os parceiros da escola, ainda hoje os temos... Eles nos ajudam, e muito...

Há um trabalho interdisciplinar que faz com que esses eventos aconteçam; há uma necessidade de comprometimento por parte dos professores, pais de alunos, funcionários... Todos são peças essenciais para que tudo dê certo...

Como citado acima, hoje tudo é mais fácil. São muitas as Políticas Públicas voltadas para incentivar esses trabalhos interdisciplinares, o próprio Parâmetros Curriculares Nacional (PCNs) traz em seu bojo orientações para que essas atividades aconteçam. O Currículo Escolar contempla essas diversidades como podemos observar nas descrições que acompanham esses relatos que embasam essa pesquisa...

Primeiro vamos aos autores HAM e HILL (1993) que apontam a preocupação com as políticas públicas, que originaram o surgimento da Análise de Política, acentuada assim no início da década de 60 que se originou a partir de duas vertentes de interesse que são:

“... as dificuldades porque passavam os formuladores de política frente à complexidade cada vez maior dos problemas com que se deparavam; e a atenção de pesquisadores acadêmicos em ciências sociais (ciência política, economia, sociologia) que progressivamente passaram a trabalhar com questões relacionadas às políticas públicas e procuraram construir e aplicar conhecimentos à resolução de problemas concretos do setor público”.

A reflexão que se pode fazer a respeito desta definição, nos leva ao universo das lembranças sociais, das memórias que representam a formação e a preservação da cultura e da identidade dos povos. Ao se pensar e repensar como se dá a formação da memória esse fato implica, obrigatoriamente, no refletir acerca de elementos culturais que fazem parte da história, seja ela recente, ou não.

Ao falarmos das Políticas como base em alguns dos pesquisadores que fundaram o campo, a "policy orientation” é o que distingue a análise de política da administração pública, nesse caso colocamo-las no espaço educacional. O caráter normativo dessa estrutura revela uma preocupação acerca de como as 
ideias que emergiram dessa análise poderiam ser aplicadas no sentido de alavancar um projeto social alternativo, quando falamos de projeto, podemos nos colocar frente aos problemas que estão inseridos no chão da escola. Nesse contexto posso citar o programa "Escola Aberta" do Governo Federal, que alavancou muitas oficinas no espaço escolar. As oficinas oferecidas eram fomentadas pelo MEC através de Parcerias. Seropédica recebeu ajuda de custo para 11 (onze) escolas nesse projeto. O Programa 'Escola Aberta' tinha como princípio:

\begin{abstract}
"Abrir as escolas aos finais de semana oferecendo alternativas de educação, lazer, cultura, esporte e formação inicial para o trabalho, para os alunos e para a comunidade em geral e particularmente para os jovens. Organizar oficinas a partir de demandas da comunidade que seriam conduzidas por talentos da comunidade e planejadas junto a ela. Contribuir para a melhoria da qualidade da educação, a inclusão social e a construção de uma cultura de paz mediante ampliação de atividades oferecidas aos alunos e à comunidade, aos finais de semana. Contribuir para a redução das violências na comunidade escolar”.
\end{abstract}

As vertentes mais importantes nesse programa era a fomentação da 'Qualificação do Projeto Pedagógico da Escola'; a 'Melhoria dos Indicadores em Educação', 'Aproximação da Comunidade e Escola'; 'Construção da Cultura de Paz’ e 'Alternativas de/e para a Inclusão Social'. Com a aplicação desse programa tiramos muitas crianças da rua e reduzimos e muito os problemas com a violência no entorno das escolas atendidas. Um dos únicos fatores que se tornam determinante para a interrupção desses programas e projetos é a descontinuidade das políticas públicas que os amparam com a troca de governos, tanto municipais, quanto estaduais e federais. 


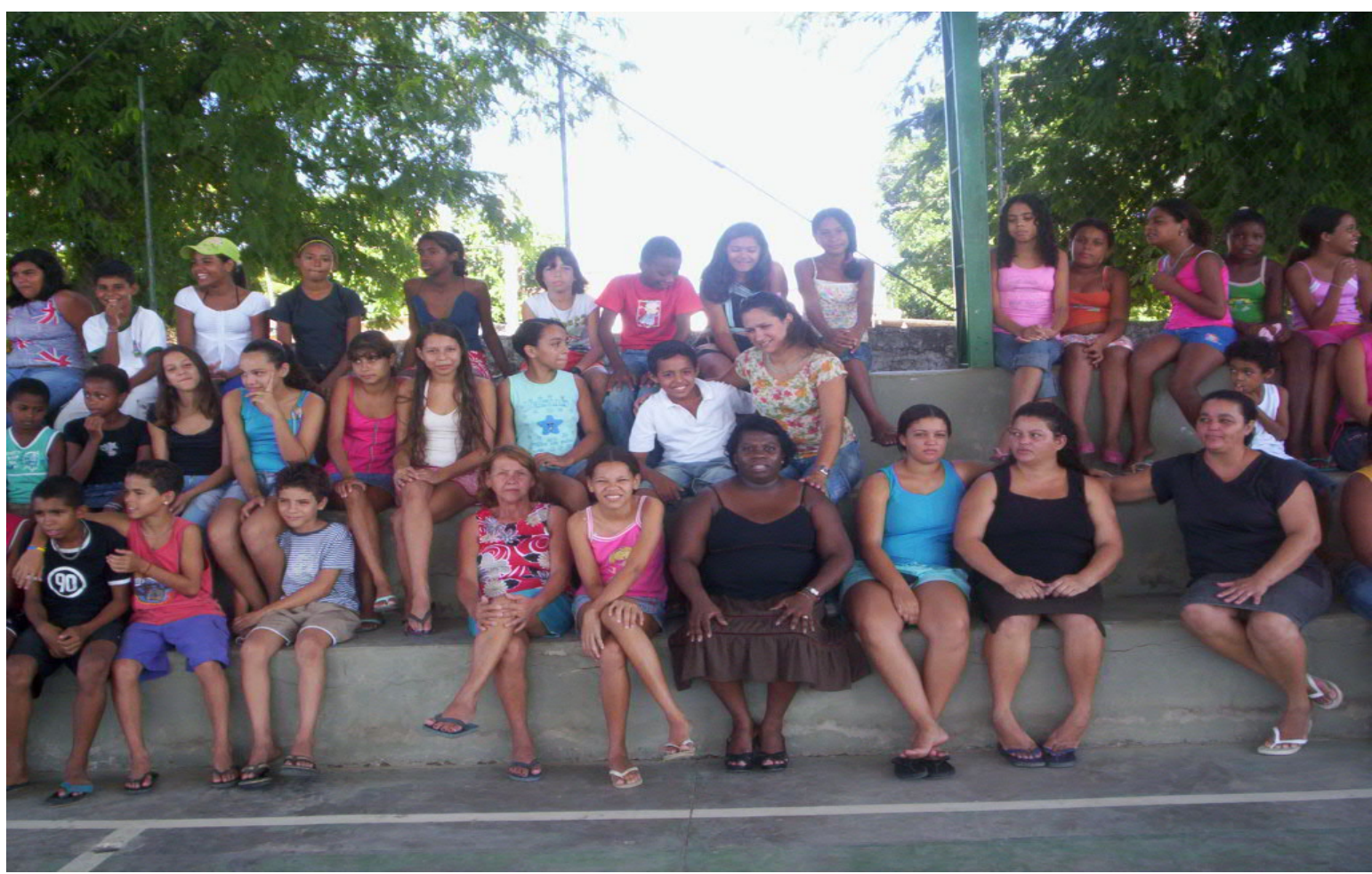

Figura 34 - Projeto "Escola Aberta" em Seropédica - ano 2005.

U

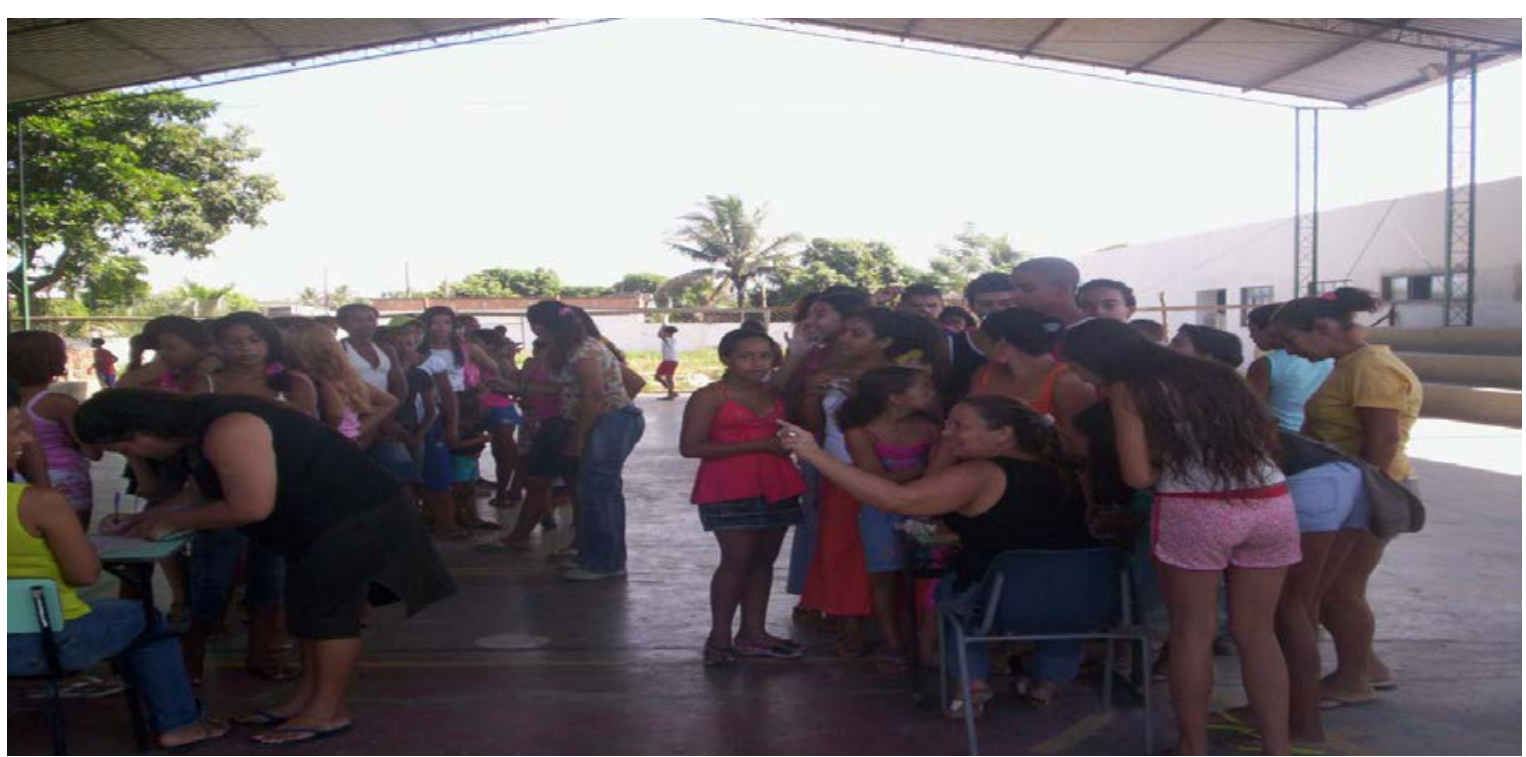

Figura 35 - Projeto "Escola Aberta" - inscrição - ano 2005. 


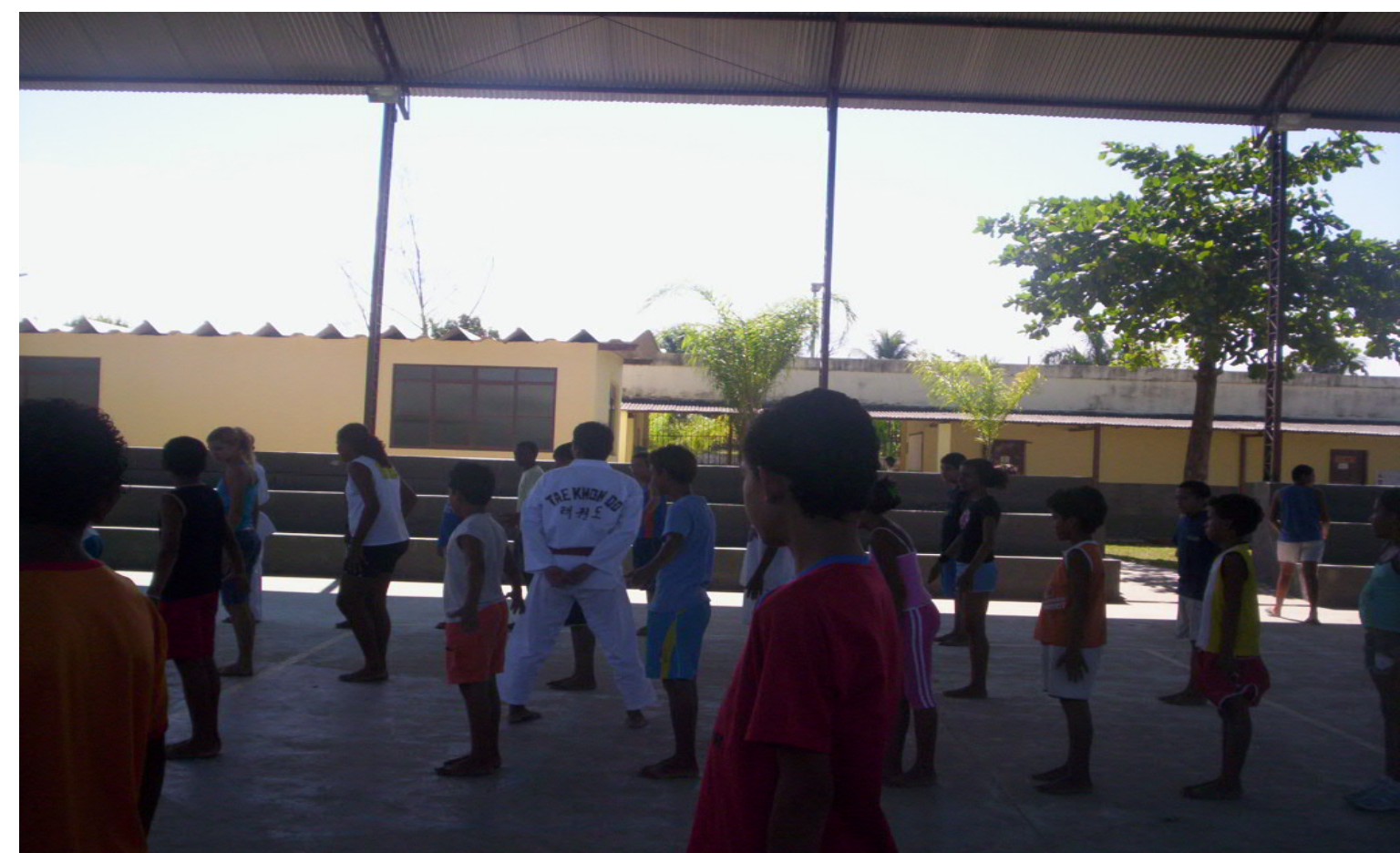

Figura 36 - Oficina de Taekwondo no projeto ‘Escola Aberta' - Ano 2005.

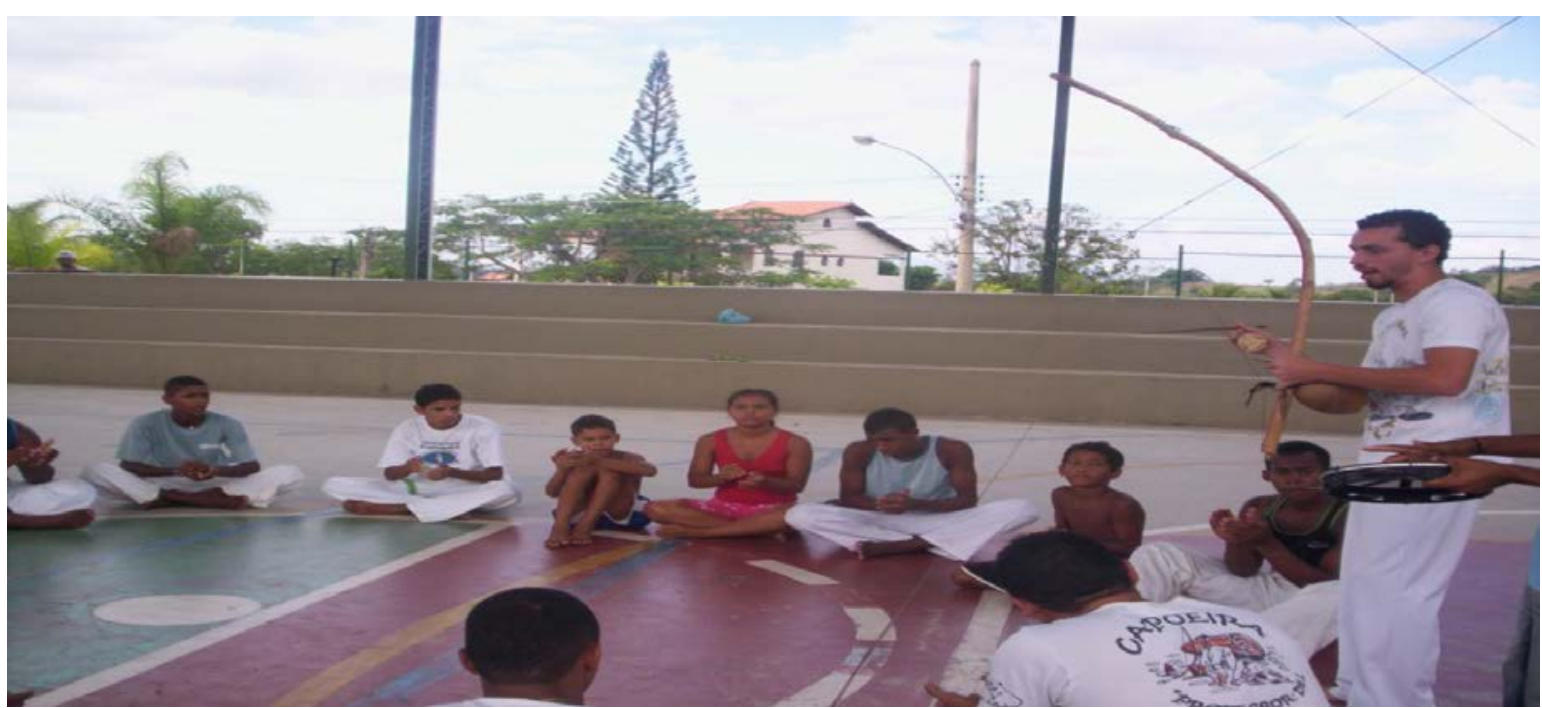

Figura 37 - Oficina de capoeira no projeto ‘Escola Aberta' - Ano 2005.

O chão da escola é que se tornou através dos tempos o espaço latente para que essas políticas acontecessem. Nesse contexto, constata-se que foi com o desenvolvimento do processo político através das políticas públicas que promoveram a partir daí a democratização no âmbito escolar, dando abertura para que a comunidade escolar pudesse escolher seus gestores. Uma escola democrática assume a busca por um viés normativo, no intuito de alcançar um processo decisório participativo. 
Para esses autores, a análise de política é também um problem-oriented, o que fomenta nesse caso a interdisciplinaridade. Dessa forma, a análise de política tem suas características pautadas em uma orientação aplicada e socialmente relevante. Por isso elas são multidisciplinar, integradora e direcionada à solução de problemas; principalmente no espaço público neste caso aqui apresentado, o espaço da escola pública que vai muito além da sua natureza ao mesmo tempo descritiva e normativa.

Segundo BRASIL nos Parâmetros Curriculares Nacionais (1996, Art. 12) havia o direcionamento para um novo caminho seguir, foi a partir das mudanças da regulamentação na década de 1990 que no Brasil, uma nova Política Curricular estabelecida pela LDB 1996 deu ao Governo Federal subsídios, e a responsabilidade de planejar as orientações curriculares para os distintos níveis educacionais, com o objetivo de garantir uma Base Curricular para todos os estudantes brasileiros. De acordo com o artigo 26 da LDB 1996, os currículos deveriam ser complementados com uma "parte diversificada” que seria definida pelos governos locais e pelas próprias escolas de acordo com as características regionais e locais.

Foi a partir da LDB 9394/96 que as escolas brasileiras ganharam - na teoria - uma maior autonomia acadêmica, financeira e administrativa. Essa Lei chegou para estabelecer que as escolas deveriam criar e executar a sua própria Proposta Pedagógica, administrar seu pessoal e os Recursos Materiais e Financeiros, para o qual deveriam criar seu próprio projeto institucional.

Deu-se início a partir daí a criação dos PPPs das escolas (Projeto Político Pedagógico) que como já se pode observar no capítulo introdutório, foi o marco inicial para que os eventos se tornassem ações.

\section{1}

\section{Prática educativa desenvolvida pela turma do $2^{\circ}$ Ano E.M}

Todas as práticas desenvolvidas foram elaboradas dentro do Projeto da escola, aqui se descreve uma "Feira Cultural" que teve como atores os alunos que além da pesquisa sobre a temática, desenvolveram apresentações a partir de trabalhos diversificados sobre cada Região do Brasil, eles pesquisaram sobre a 
história dos estádios construídos para a realização da Copa. Coube a turma do $2^{\circ}$ ano Ensino Médio do C. M. Dr. Aurelino G. Barbosa, que ficou sob a minha responsabilidade, pesquisar sobre a Região Centro-Oeste. Os alunos montaram um banner que trazia todas as informações culturais possíveis da região. Foi realizada uma gincana a qual motivou os alunos por meio da competitividade de tarefas, ornamentações, músicas, comidas típicas feitas pelos alunos e danças com premiação de fundo cultural. Segue abaixo a descrição e fotos das tarefas da turma:

\section{GINCANA}

Copa Aurelino 2014 - Horário 12:20 às 17:00 horas

\section{$17: 20$ às 21:30 horas}

Fotos das Barracas

Ornamentação das Barracas de acordo com as Regiões.

- Comidas Típicas

- Cultura

- Arte

- Manifestação Cultural (Dança, Teatro, Paródia...)

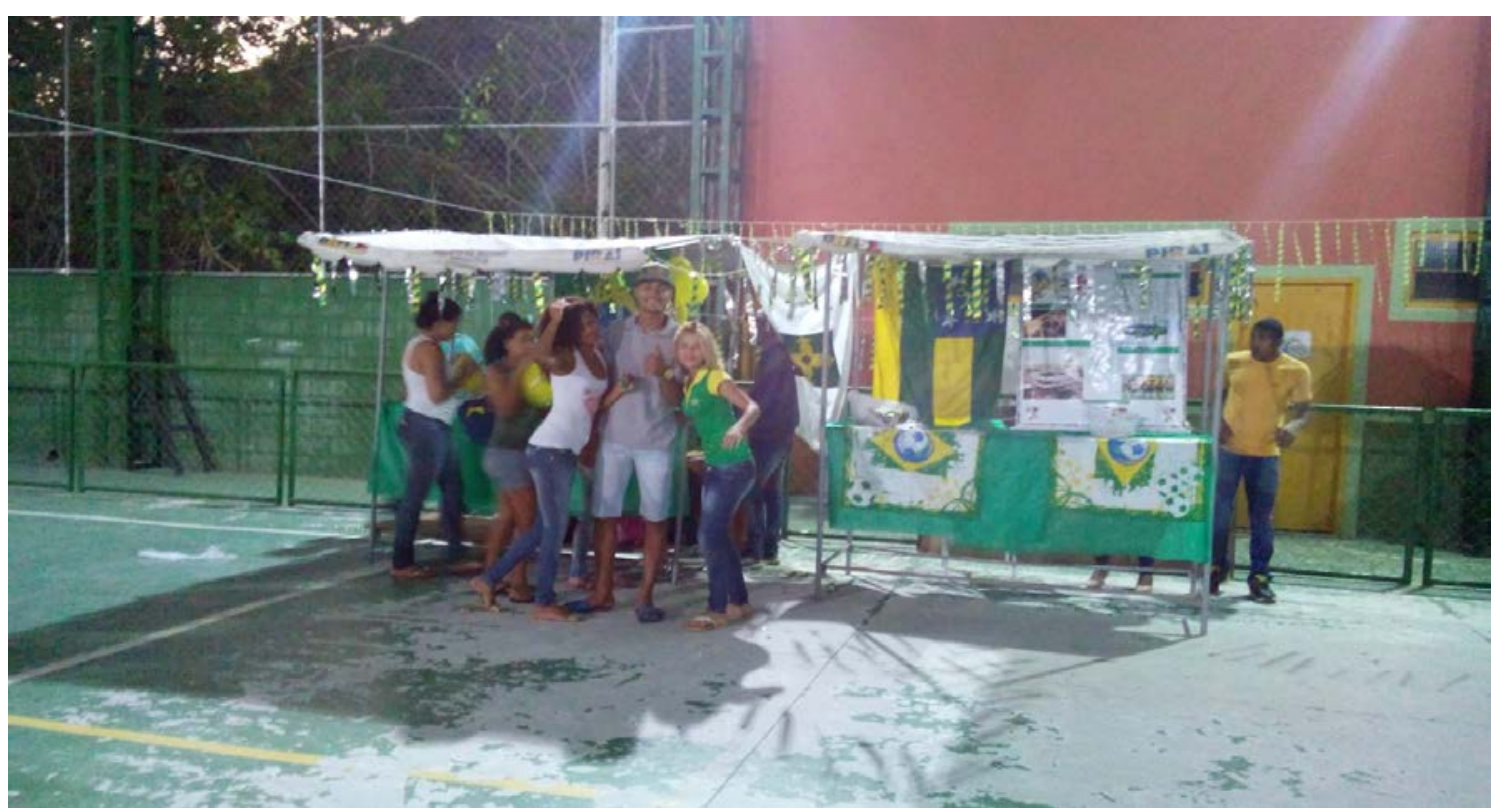

Figura 38 - Foi montada uma barraca com motivos das cores do Brasil. 


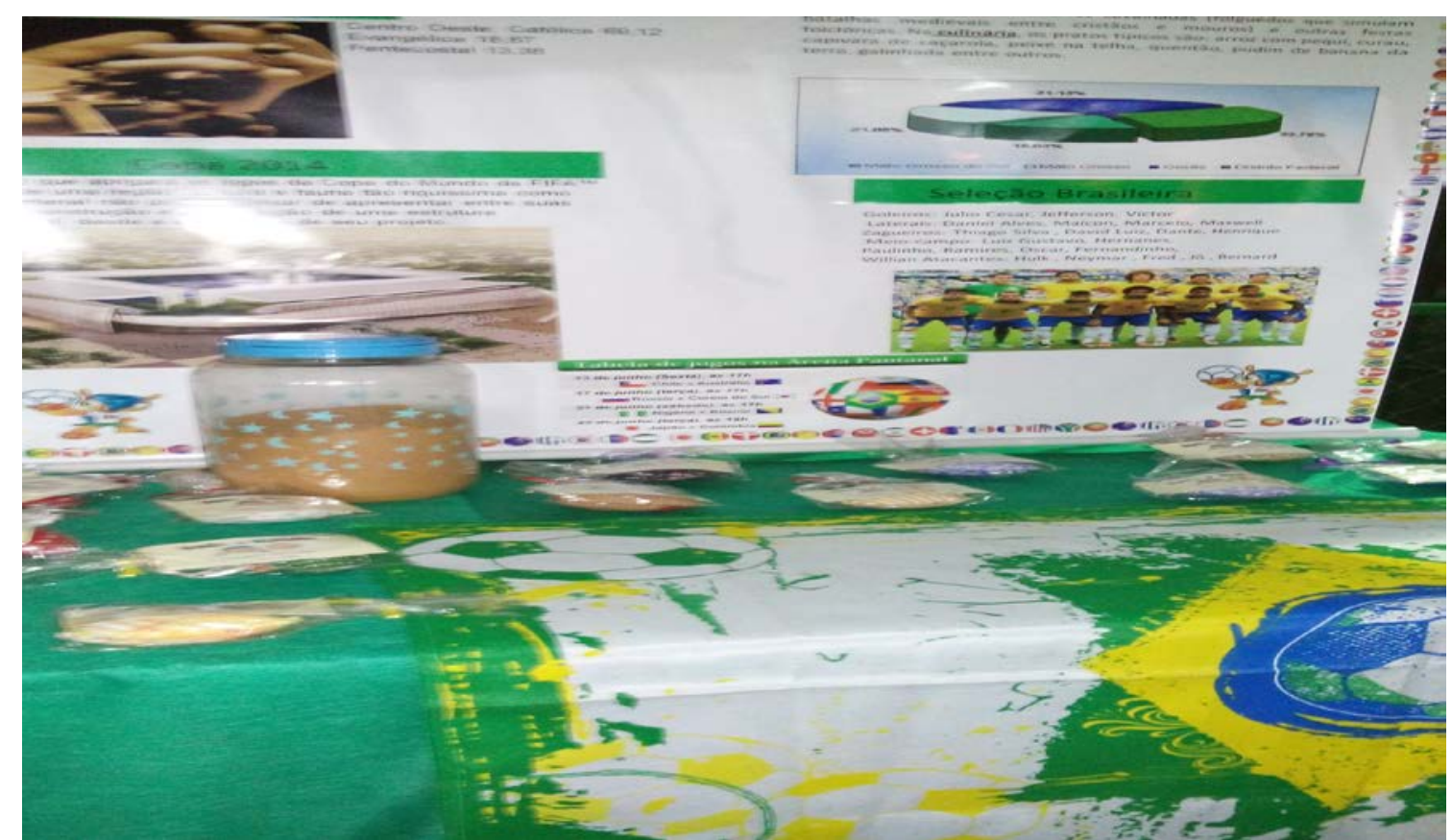

Figura 39 - Um Banner explicativo sobr a região e os atletas.

\section{2}

\section{As turmas de EJA - uma viagem no espaço escolar}

Essa é uma das expressões maiores da EJA (Educação de Jovens e Adultos) no trabalho com a juvenilização, que apesar de ser um fenômeno observado desde a década de 1990, sendo assumida atualmente na escola noturna mudando totalmente o perfil dessa modalidade de ensino que no passado era composta mais especificamente por adultos que não puderam estudar no tempo certo, e agora tornou-se também um espaço para jovens trabalhadores e jovens com distorção idade e série que estudavam no ensino diurno. As novas características das turmas são visíveis nas fotos. A mudança dessa clientela foi distinta... 


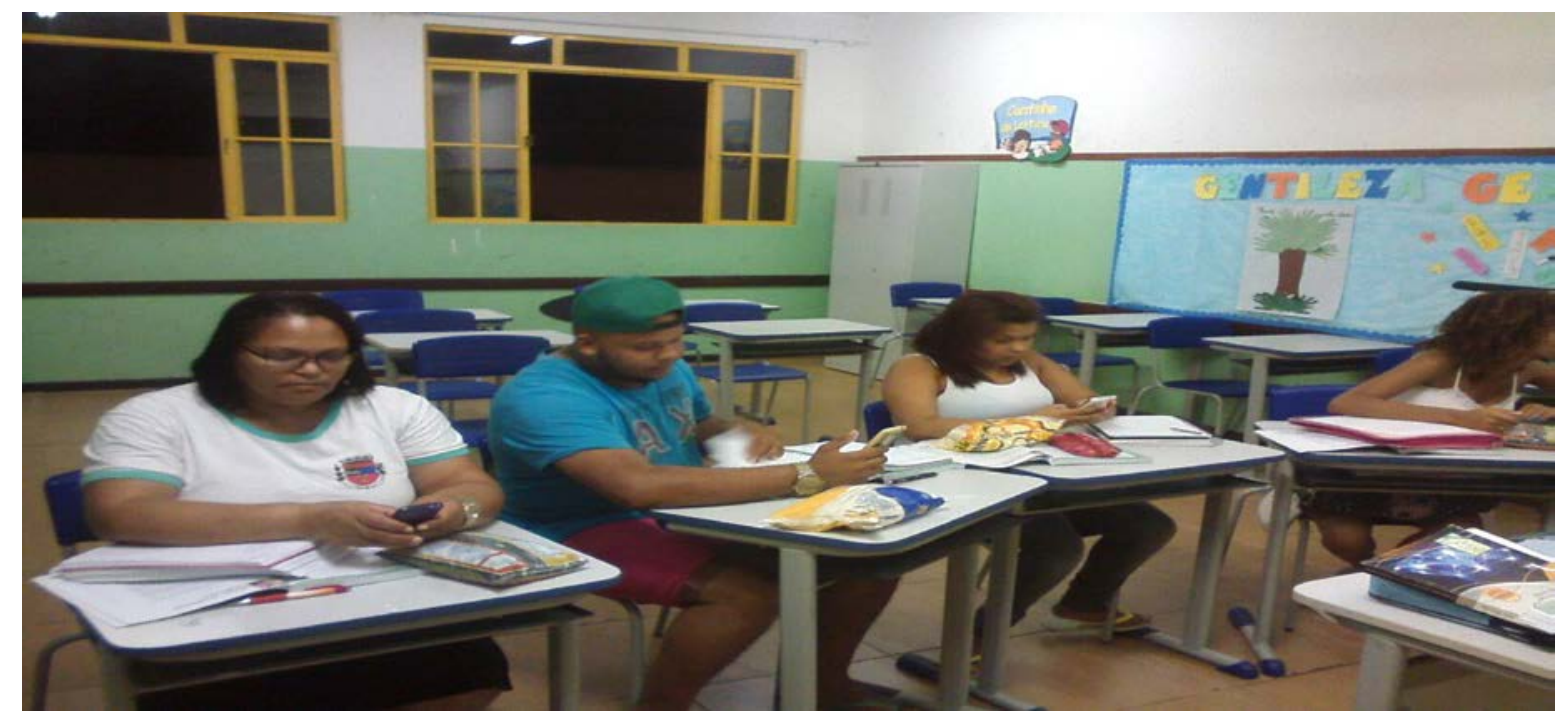

Figura 40 - Turma do Ensino Noturno do Colégio Municipal Doutor Aurelino G. Barbosa.

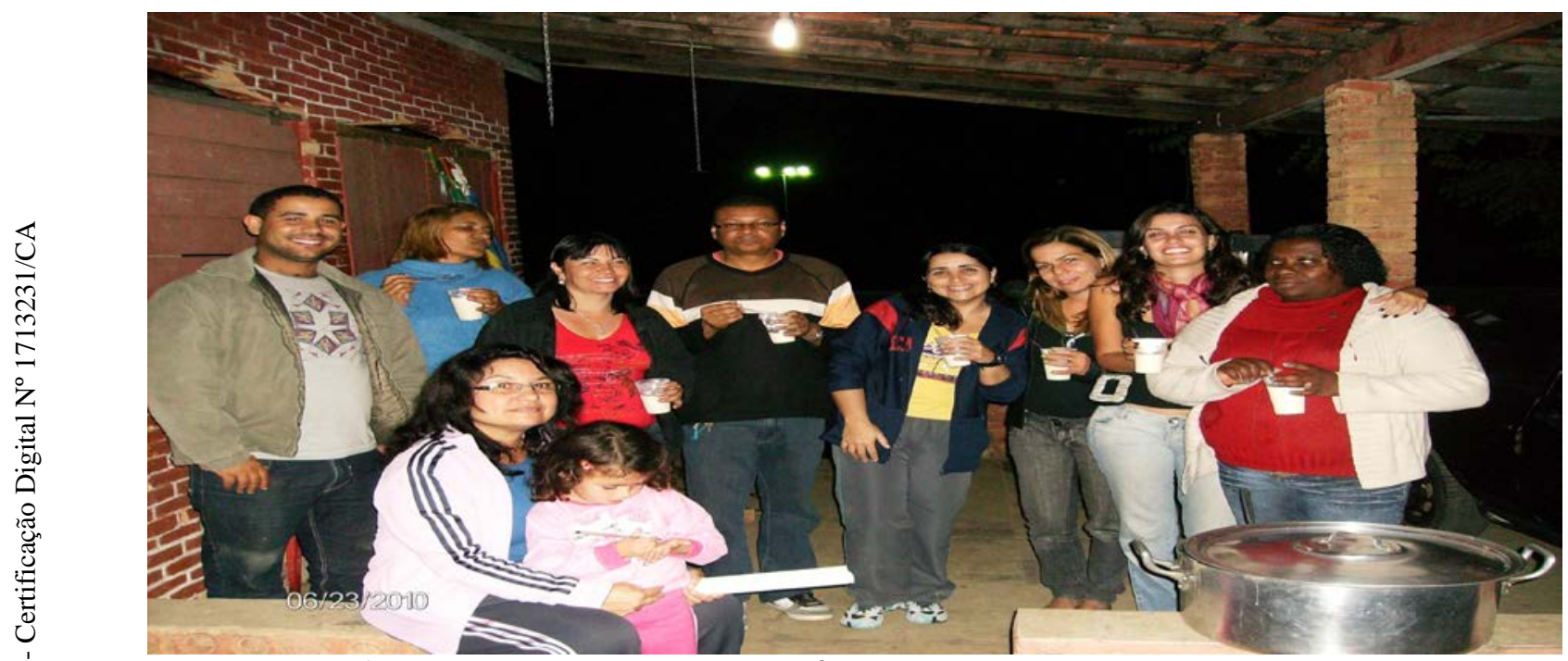

Figura 41 - Professores da EJA e do Ensino Médio - 2010. 


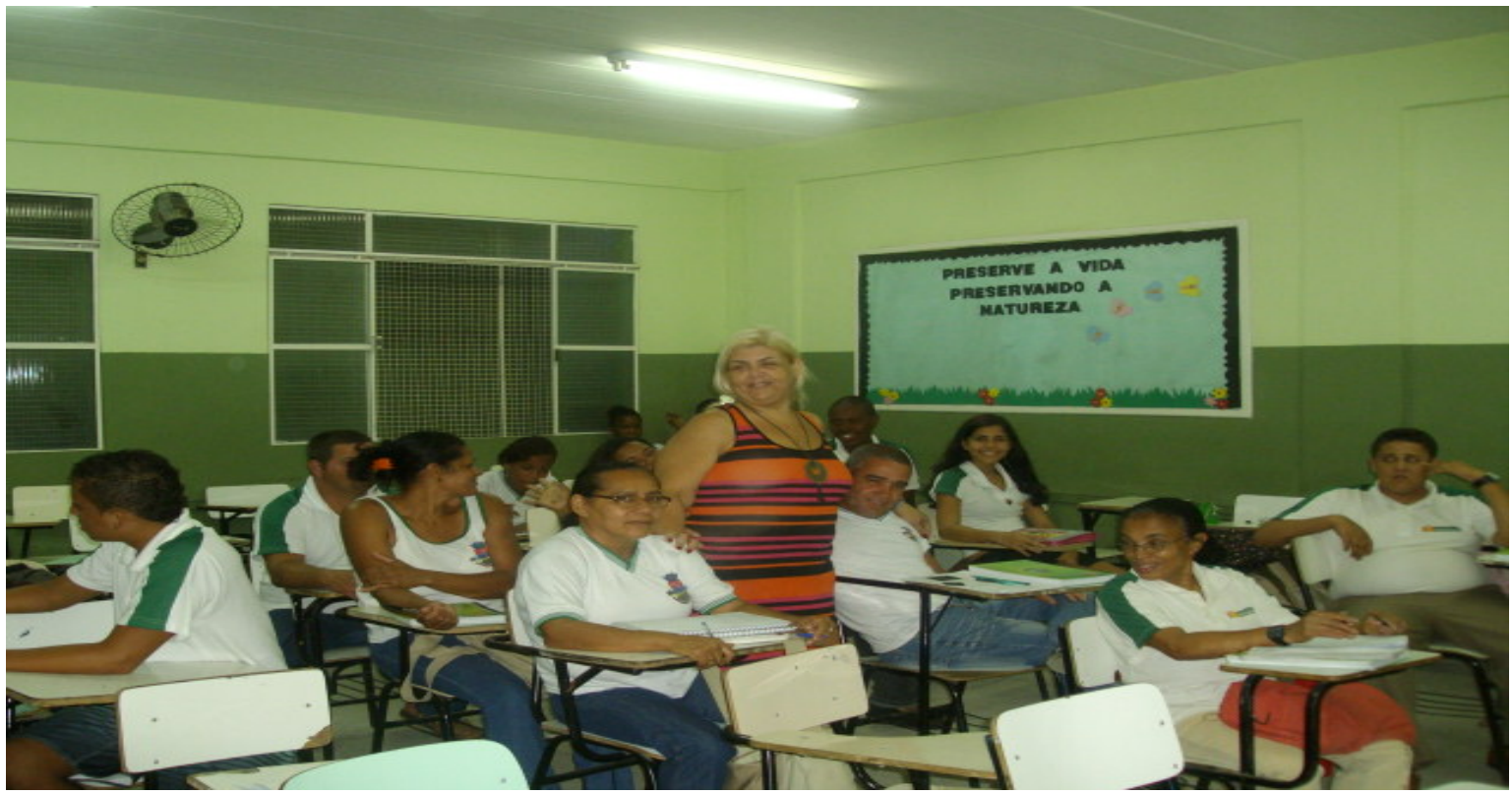

Figura 42 - Turmas da EJA da Escola Municipal Panaro Figueira.

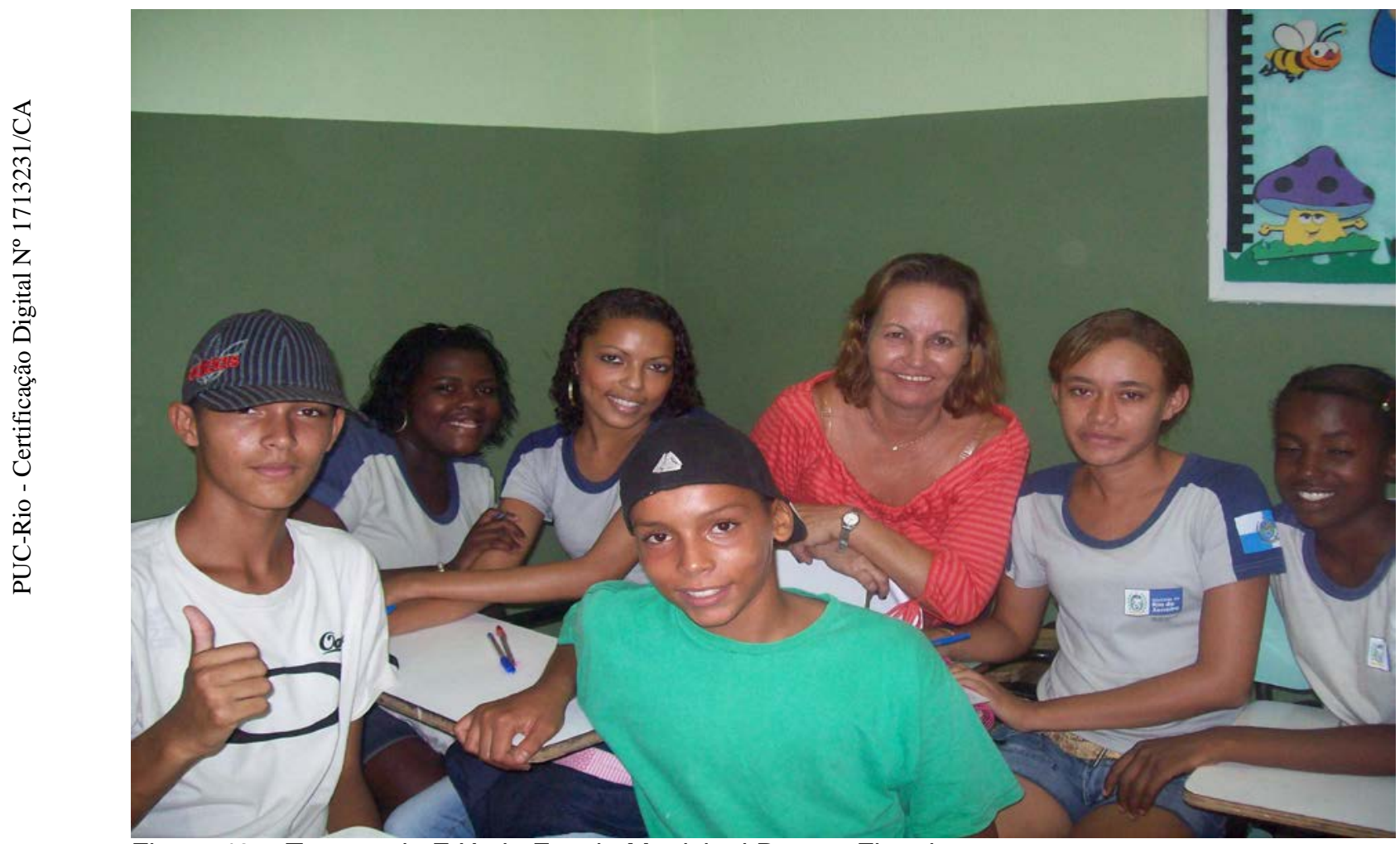

Figura 43 - Turmas da EJA da Escola Municipal Panaro Figueira. 


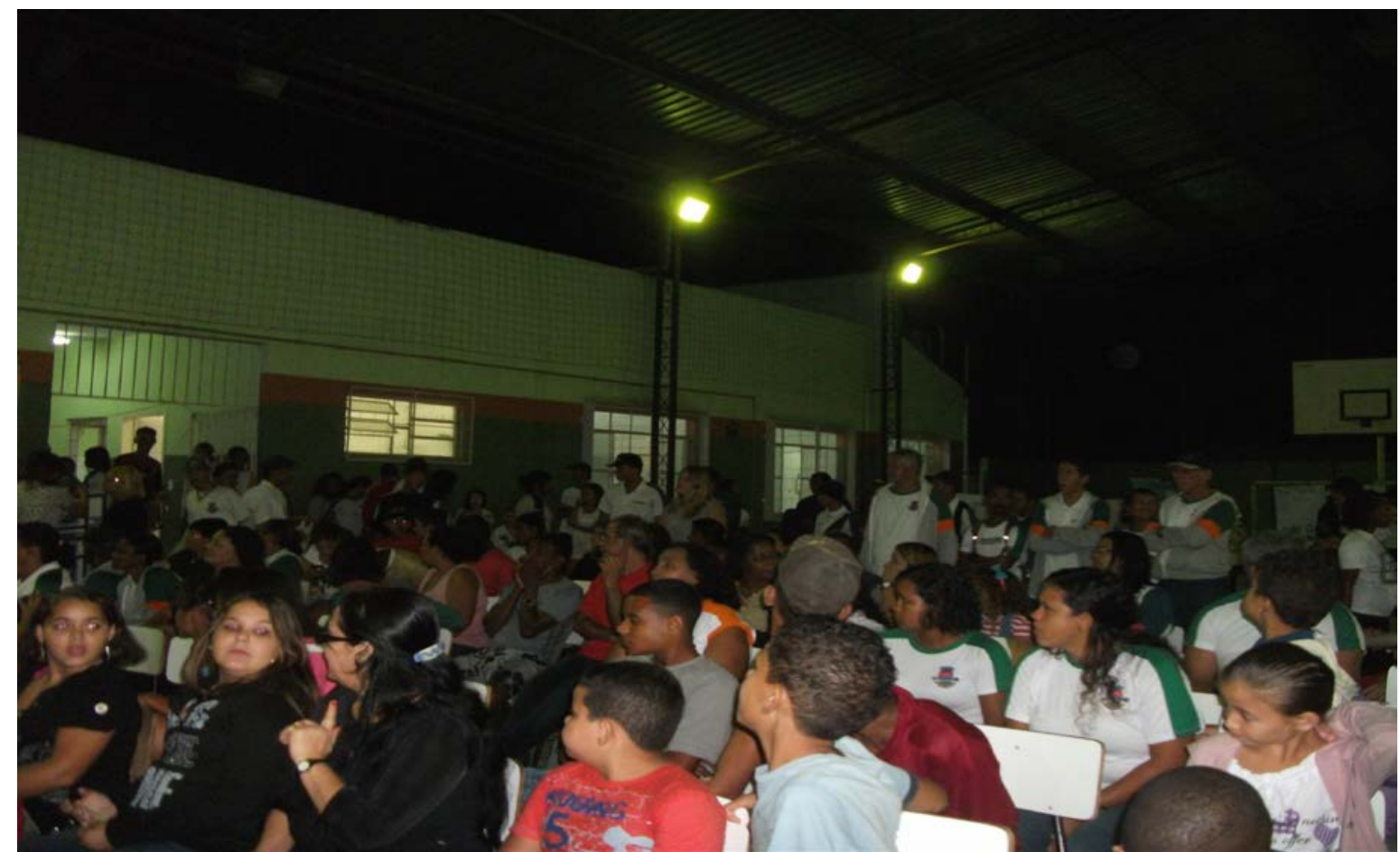

Figura 44 - Alunos, professores e comunidade escolar assistindo a apresentação dos trabalhos desenvolvidos pela EJA da Escola Municipal Panaro Figueira.

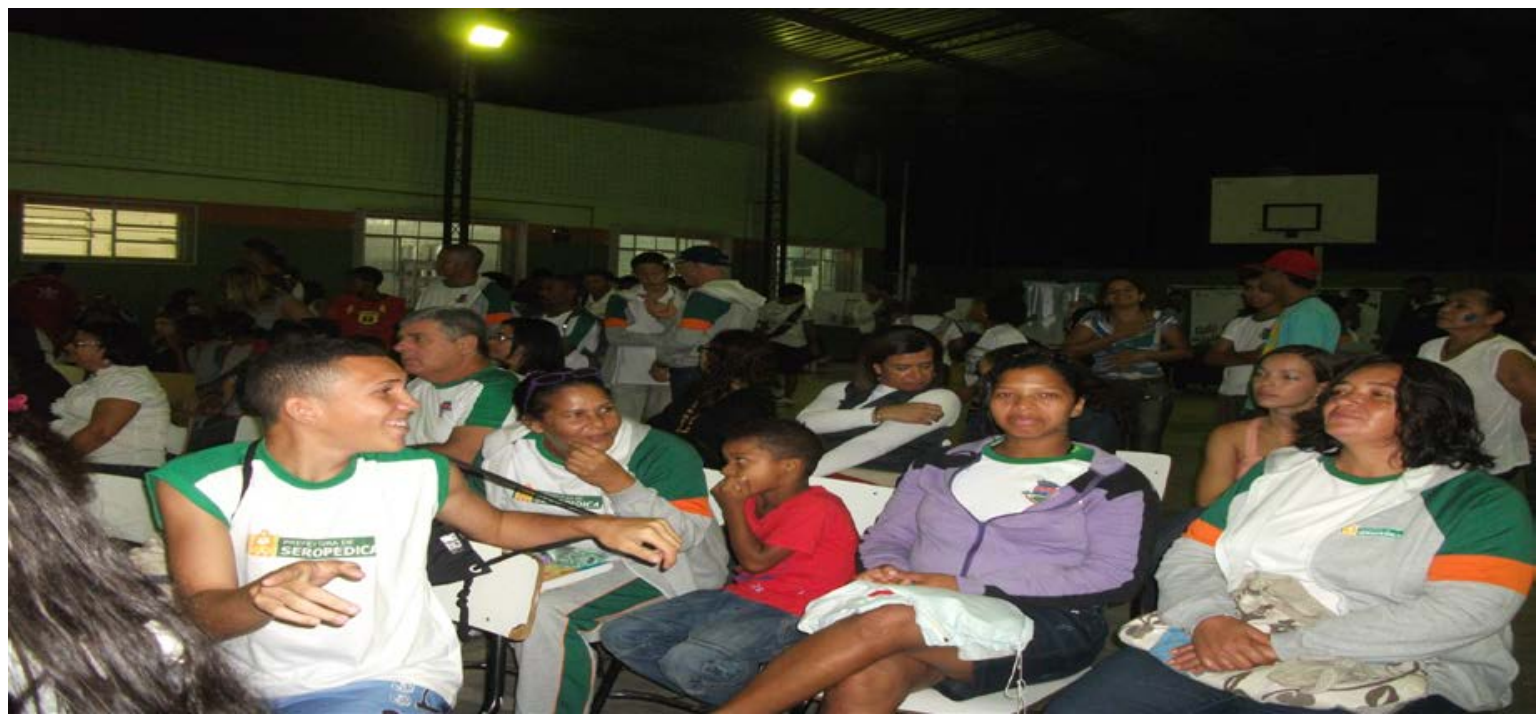

Figura 45 - Alunos, professores e comunidade escolar assistindo a apresentação dos trabalhos desenvolvidos pela EJA da Escola Municipal Panaro Figueira. 


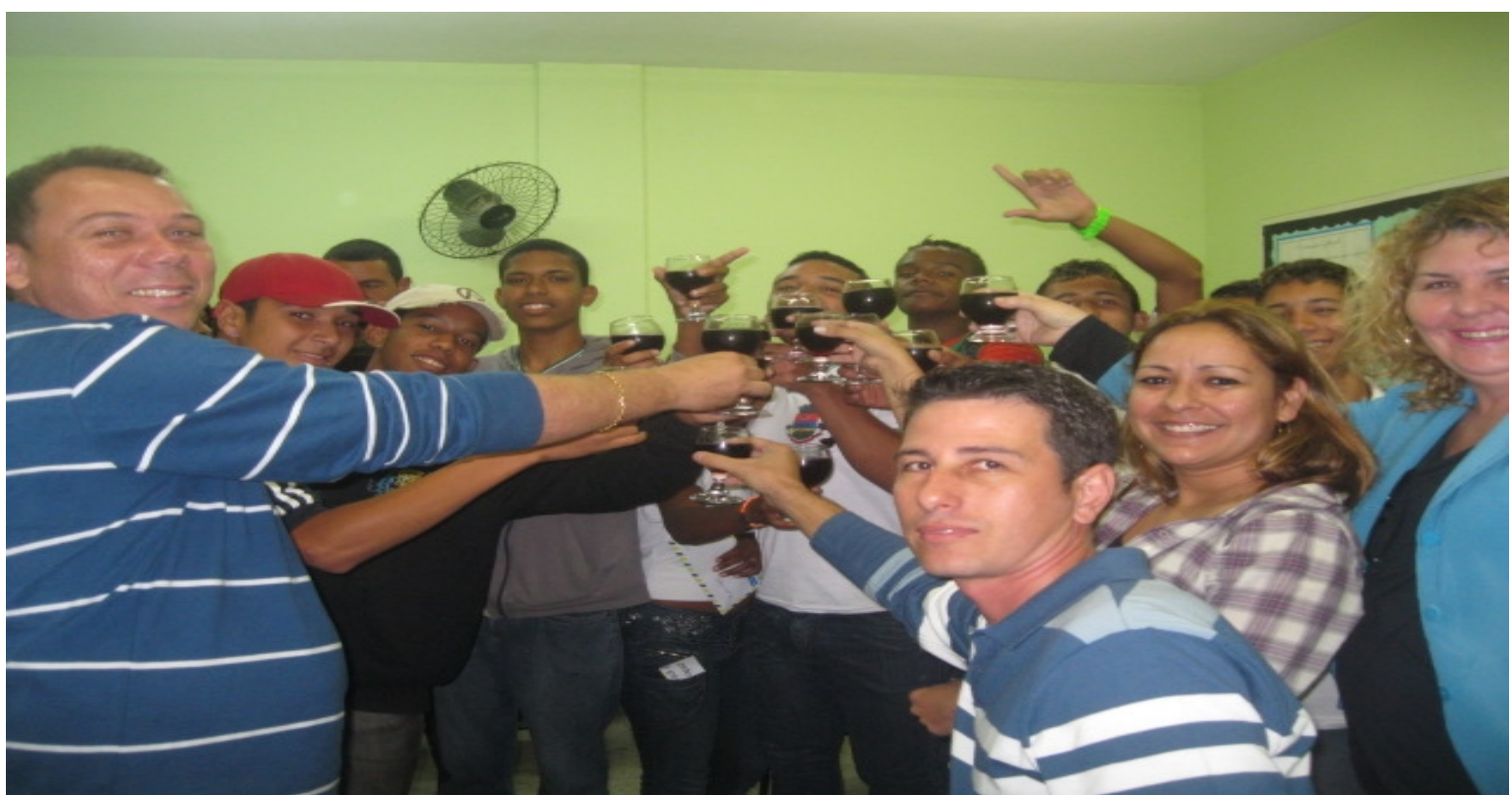

Figura 46 - Diretor, alunos, coordenadora da EJA da Escola Municipal Panaro Figueira em celebração pelo final das apresentações dos trabalhos desenvolvidos na Culminância dos Projetos. Momento ímpar...

O Colégio Municipal Doutor Aurelino Gonçalves Barbosa que fica no município de Piraí, Cidade Serrana - RJ; diferentemente da Escola Municipal Panaro Figueira que fica no município de Seropédica - Baixada Fluminense - RJ; possui uma educação que se encontra inserida em um contexto social um tanto diferente da Escola Municipal Panaro Figueira, pois se encontra em uma área da periferia, em que há uma aplicabilidade maior de aparatos tecnológicos para auxiliar como ferramenta de aprendizagem, por isso os trabalhos desenvolvidos na maioria das vezes vão para além do espaço escolar; como é o caso já citado na parte introdutória desta dissertação a respeito do FESTEJA, do FEMUPI e da FESTA FOLCLÓRICA; o FESTEJA surgiu a partir dos trabalhos das turmas da EJA e com isso tornou-se uma expressão maior daqueles que ficaram fora da escola por muitos anos, e ao retornarem puderam expressar de alguma forma, através de seus trabalhos e danças a expressão da sua arte; o FEMUPI ocorre no Centro da Cidade de Piraí com a instauração de palco para a apresentação dos trabalhos desenvolvidos pelos alunos, que traz como plateia a comunidade escolar de todas as escolas do município e convidados. O FEMUPI (Festival de Música da Cidade de Piraí) é um trabalho desenvolvido com os alunos produzido através da adaptação de músicas de grandes cantores em tom de Paródia, em trabalhos desenvolvidos com a participação dos alunos e professores de Língua Portuguesa, 
Artes e Educação Física em parceria interdisciplinar com todos os professores da escola e da rede; a FESTA FOLCLÓRICA é desenvolvida a partir da criação de trabalhos diversificados desenvolvidos por cada escola do município envolvendo todas as séries desde a Educação infantil até o Ensino Médio, que montam danças de acordo com a região que a cada escola é direcionada, comidas típicas que é distribuída gratuitamente pelas escolas as outras escolas e aos convidados, e vai ao encontro da cultura de cada Estado do Brasil, trazendo as suas representações culturais. Os fatos que permeiam esses eventos podem ser observados nas fotos que seguem abaixo.

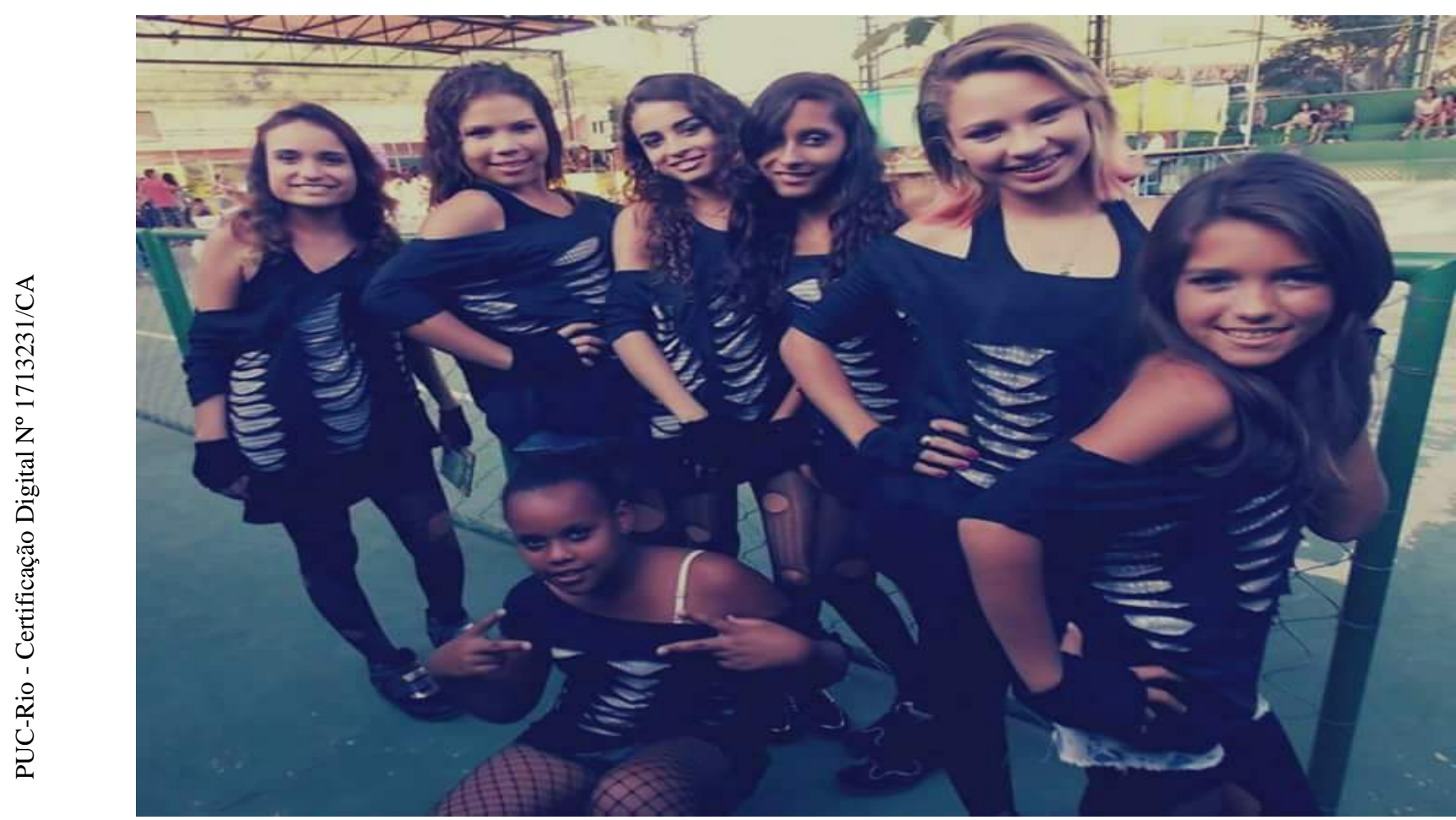

Figura 47 - Alunas do C. M. Dr. Aurelino G. Barbosa caracterizados para se apresentarem no FEMUPI - Festival de Paródia. 


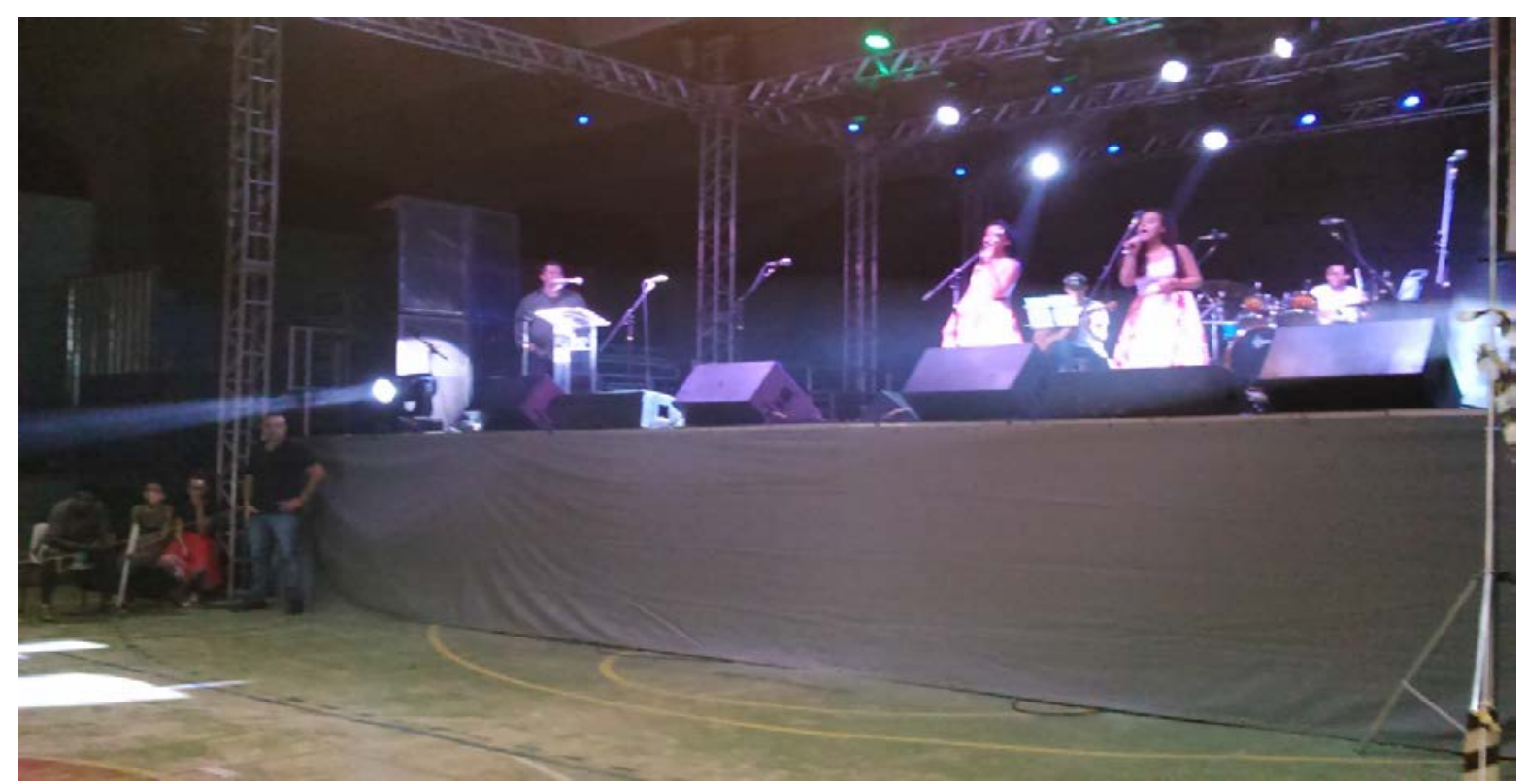

Figura 48 - Alunas do C. M. Dr. Aurelino G. Barbosa apresentando-se no FEMUPI de Piraí.

Ao falar de "Pedagoginga”, Allan da Rosa nos leva a imaginar o que seria essa "Ginga", ai vem o pensamento dos trabalhos de dança desenvolvidos nos espaços escolares na visualização das danças folclóricas que acontecem pelo Brasil a fora, e que os alunos quando em um trabalho maior nos aparece com danças regionais que são apresentados em diferentes momentos no espaço escolar.

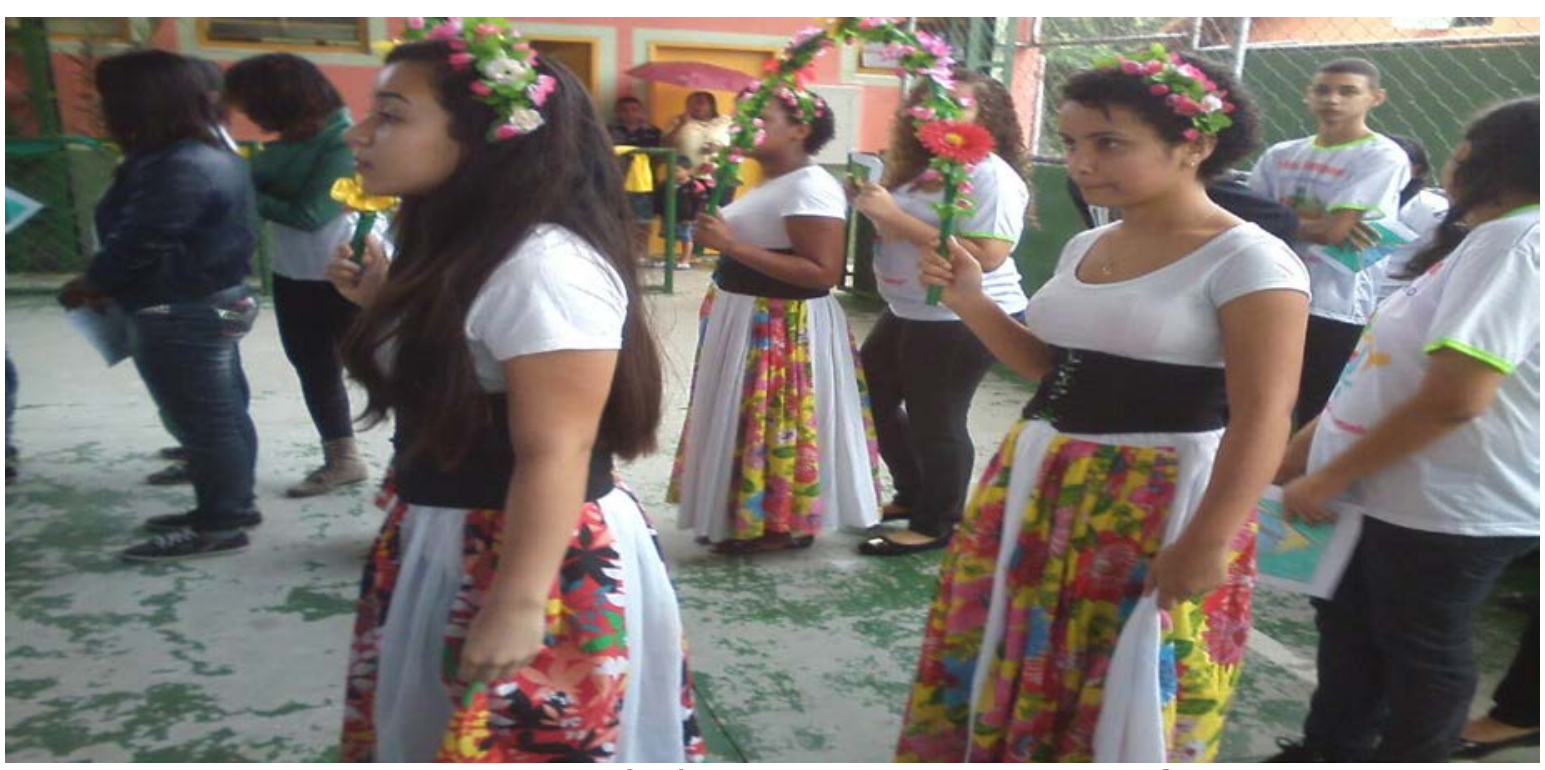

Figura 49 - Apresentação da dança no Colégio Municipal Doutor Aurelino G. Barbosa. 


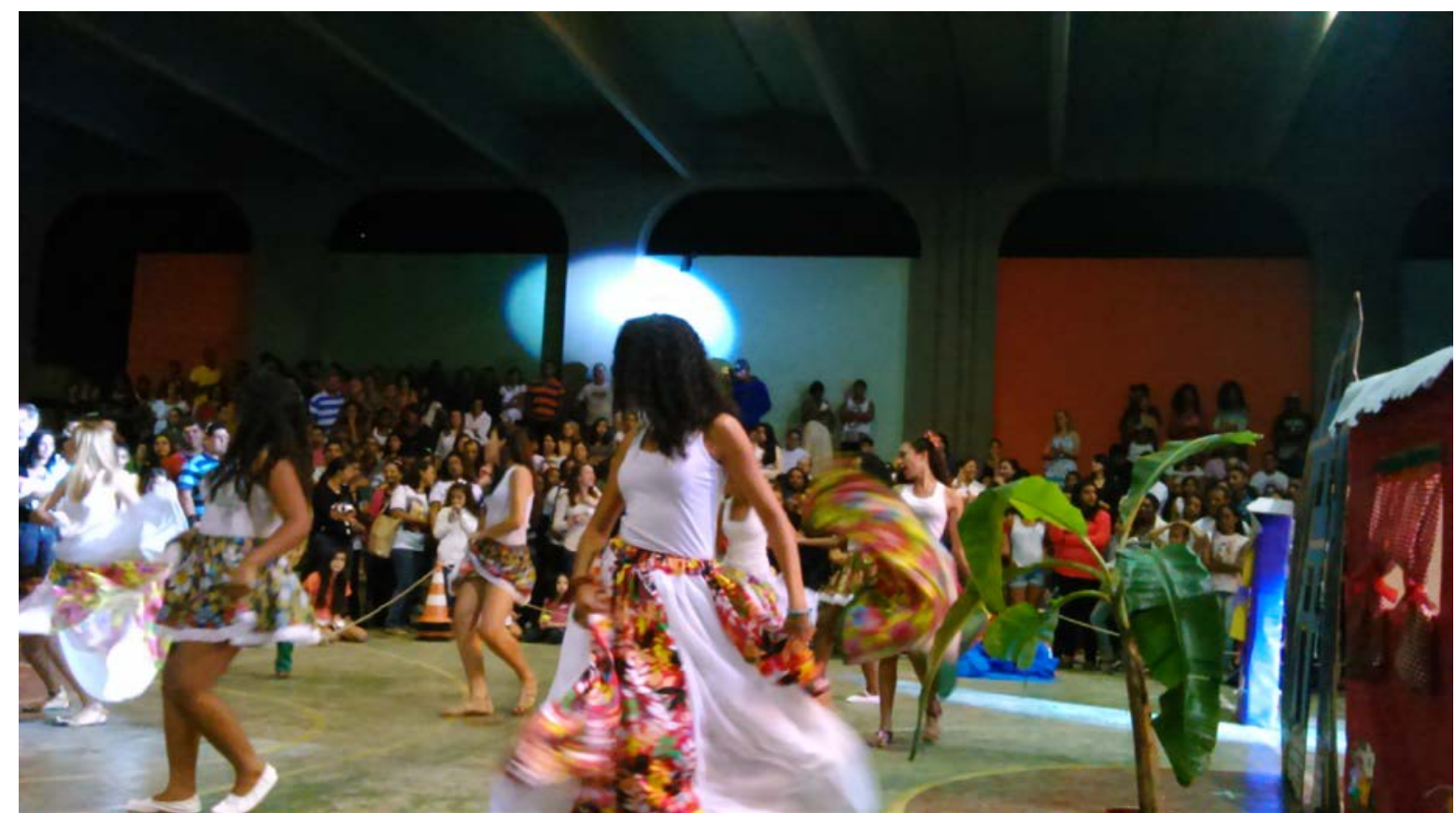

Figura 50 - Apresentação da dança do Colégio Municipal Doutor Aurelino G. Barbosa em Piraí.

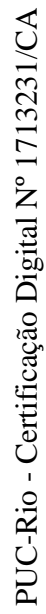




\section{Projetos de leitura}

\section{1}

\section{Passeios Culturais - Janela para o Mundo}

“A escola amplia o horizonte dos alunos, dá-lhes acesso a conhecimentos, ciências, lugares e saberes que eles não perceberiam sem ela; vai além da superficialidade que as mídias e outros espaços oferecem. A função da escola é, então ensinar às crianças como o mundo é, e não instruí-las na arte de viver" (ARENDT, 2000, p. 246)

Na concepção de alguns dos autores lidos com relação a conceituação de Educação como Paulo Freire, Alan da Rosa, Hannah Arendt e outros; a escola é um espaço legitimado pela tradição, seja de que forma for: seja pelas propostas curriculares, ou seja, em suas articulações para o desenvolvimento do saber. Dessa forma, a escola é responsável por traduzir os conhecimentos científicos, técnicos, estéticos de forma que o aluno os compreenda e se sintam dentro do mundo. Nesse contexto, a Educação Escolar assume a responsabilidade pelo mundo em forma de autoridade; centrada na relação de saberes, na negociação e se um educador se nega a assumir essa autoridade como representante do conhecimento; deve-se tomar isso como uma recusa a assumir a responsabilidade pelo mundo para o qual as crianças foram trazidas. Essa posição é que se torna relevante para que se saiba como a autoridade do professor na sala de aula, no espaço escolar mostra a visão assumidamente educativa da escola como lugar de aprendizagem, que apresenta para o aluno os conhecimentos sistematizados. A escola é o campo que deve estar aberto a novos saberes, dando a esses saberes subsídios, significados e razão de mundo e para o mundo.

Os passeios culturais já mencionados surgiram como projeto de ampliação de conhecimento para novas aprendizagens, aprendizagens que englobam o mundo da leitura e abrem novas perspectivas de vida. Ao verificar que grande parte dos alunos não tinha acesso a visitas e passeios, por não terem dinheiro para sair do local em que vivem, ou mesmo por já cedo terem que trabalhar para ajudar nas despesas de suas casas; ou mesmo por fatores sociais que acabavam 
influenciando em seu rendimento escolar criou-se esse projeto de excursão. Foi em busca de novos saberes, que são conquistados através do conhecimento de mundo, que criou-se aqui essa janela para o conhecimento. Conhecimento esse que deve ir muito além da teoria, em busca de uma prática que atenda as necessidades dos alunos.

Ampliamos assim, com esses passeios, muitas histórias de vida; dando aos alunos subsídios para irem além do que se espera daqueles que não tiveram muitas oportunidades. As excursões feitas para diferentes lugares deram a oportunidade de integração de toda a escola, por laços de amizades que acabam se perpetuando pela vida.

O "Projeto de incentivo a leitura” foi desenvolvido no Colégio Municipal Dr. Aurelino Gonçalves Barbosa, que tinha como diretora a professora Sandra Rosa Jachinto. Por ser uma gestora participativa e atuante, esta procurava apoiar todos os trabalhos que eram desenvolvidos.

Esse projeto foi idealizado e desenvolvido por mim enquanto educadora, juntamente com outros professores tendo como meta levar os alunos dessa escola a se tornarem leitores mais efetivos, transformando suas vidas. Porque a partir desse contexto, eles intencionaram traçar outros caminhos em suas vidas. O passeio que eles mais gostam, é a ida a Bienal do Livro. Esse passeio acontece de dois em dois anos, mais os alunos ficam esperando esse momento com muita expectativa. 


\section{A - PASSEIO A BIENAL DO LIVRO}

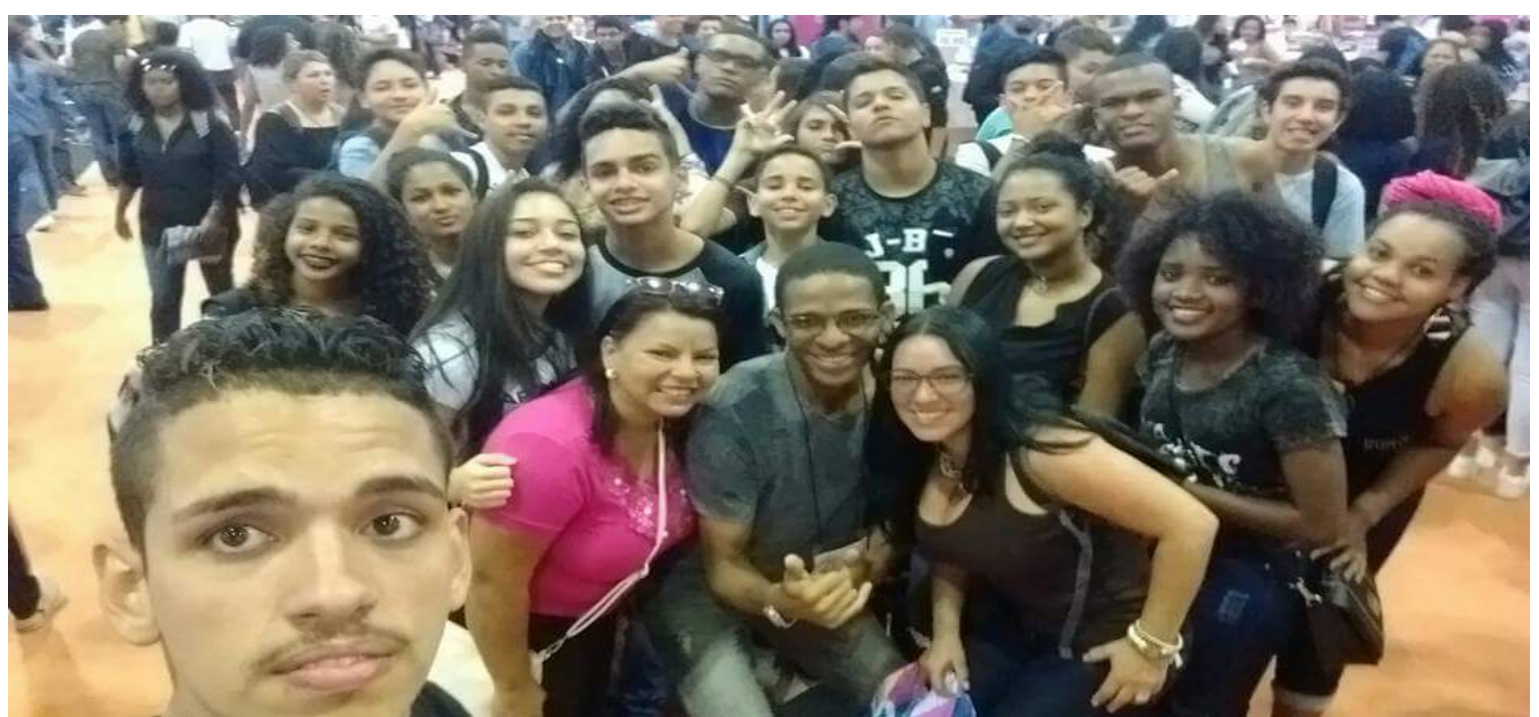

Figura 51 - Alunos na visitação a Bienal do Livro no Rio de Janeiro - 2018.

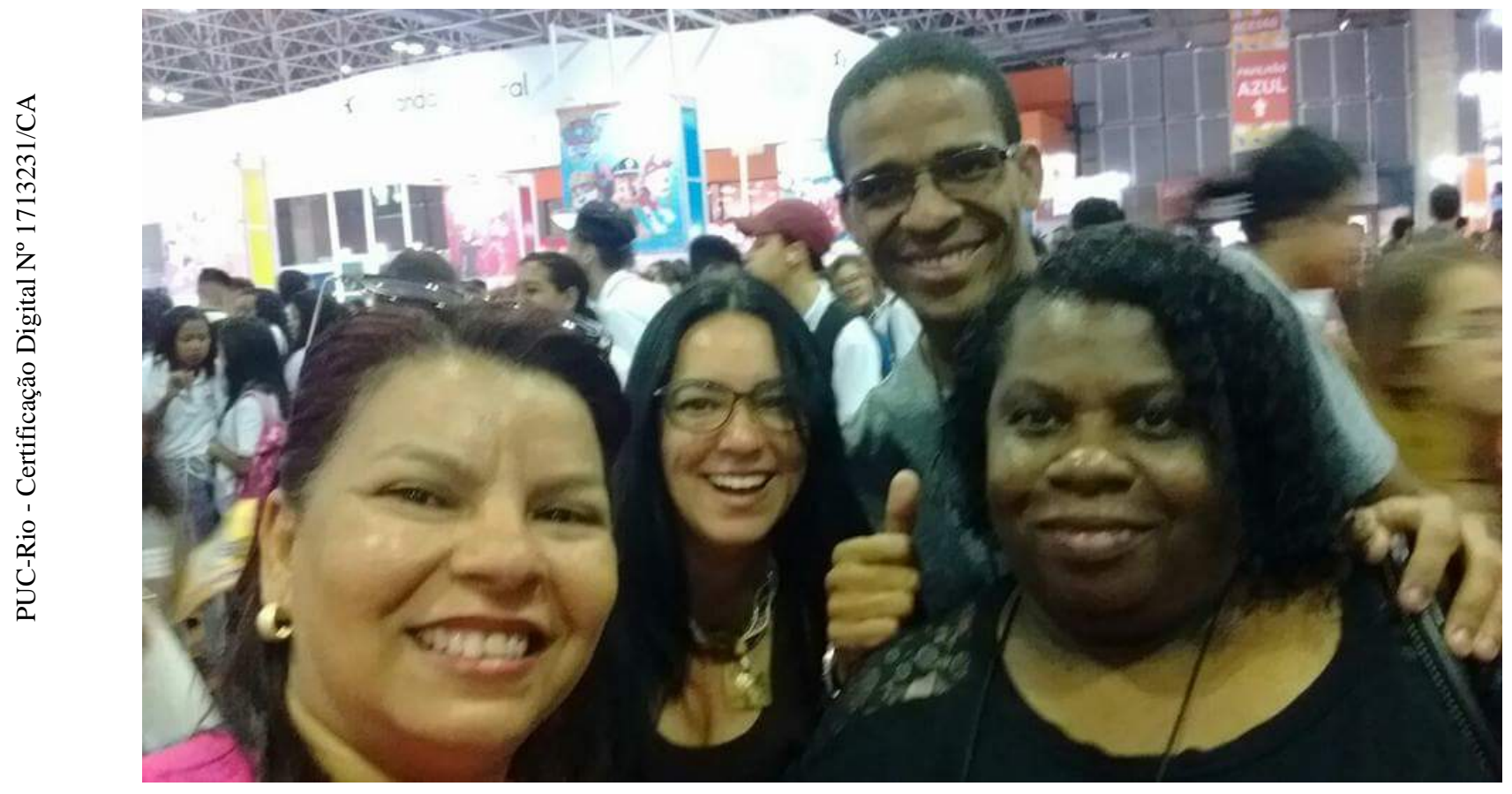

Figura 52 - Professores e Orientadores Educacionais e Pedagógicos na visitação junto com os alunos na BIENAL. 


\section{B - PASSEIO A RIO+20}

Passeio a Rio+20 foi uma viagem ao conhecimento científico, pois esses alunos tiveram a oportunidade de interagir com alunos de outras escolas, conhecer as novas perspectivas no mundo das ciências para o estudo do meio ambiente. Esse projeto foi desenvolvido em parceria com outros professores, e teve como grau de interesse informar e ampliar o conhecimento dos alunos na preservação do Meio Ambiente. Antes de fazermos esse passeio turístico, os alunos foram informados o que esse conhecimento lhes proporcionaria.

Segundo a guia que nos acompanhou a essa viagem pelo conhecimento, a Rio+20 era uma Conferência das Nações Unidas sobre Desenvolvimento Sustentável, que estava acontecendo na cidade do Rio de Janeiro de 13 a 22 de junho de 2012. Dela participaram líderes dos 193 países que faziam parte da ONU.

Seu principal objetivo era renovar e reafirmar a participação dos líderes dos países com relação ao desenvolvimento sustentável no planeta Terra. Essa foi, portanto, uma segunda etapa da Cúpula da Terra (ECO-92) que havia ocorrido há 20 anos na cidade do Rio de Janeiro que envolvia um balanço desses últimos 20 anos em relação ao meio ambiente; a importância e os processos da Economia Verde; as ações para garantir o desenvolvimento sustentável do planeta; aumentar o potencial criando maneiras de eliminar a pobreza; integrar a governança internacional no campo do desenvolvimento sustentável.

Infelizmente para os interesses governamentais o resultado da Rio+20 não foi o esperado. Os impasses, principalmente entre os interesses dos países desenvolvidos e em desenvolvimento, acabaram por frustrar as expectativas para o desenvolvimento sustentável do planeta. O documento final apresenta várias intenções e jogou para os anos seguintes a definição de medidas práticas que garantissem a proteção do meio ambiente. Muitos analistas que fizeram parte desse evento afirmaram que a crise econômica mundial, principalmente nos Estados Unidos e na Europa, prejudicou as negociações e tomadas de decisões práticas.

Já para os alunos da escola que foram ao passeio, esses ficaram encantados e eufóricos com as novidades que a eles foram apresentadas em forma de 
informação e orientação para se criar um mundo sustentável. Isso serviu de incentivo para o desenvolvimento de alguns trabalhos de ciências na escola. Já para a área de Língua Portuguesa, foram desenvolvidas redações que mostravam como as informações recebidas por esses alunos naquele espaço visitado, deu-lhes consciência da importância da vida na terra, e da sustentabilidade que cabe a nós seres humanos desenvolvê-las.

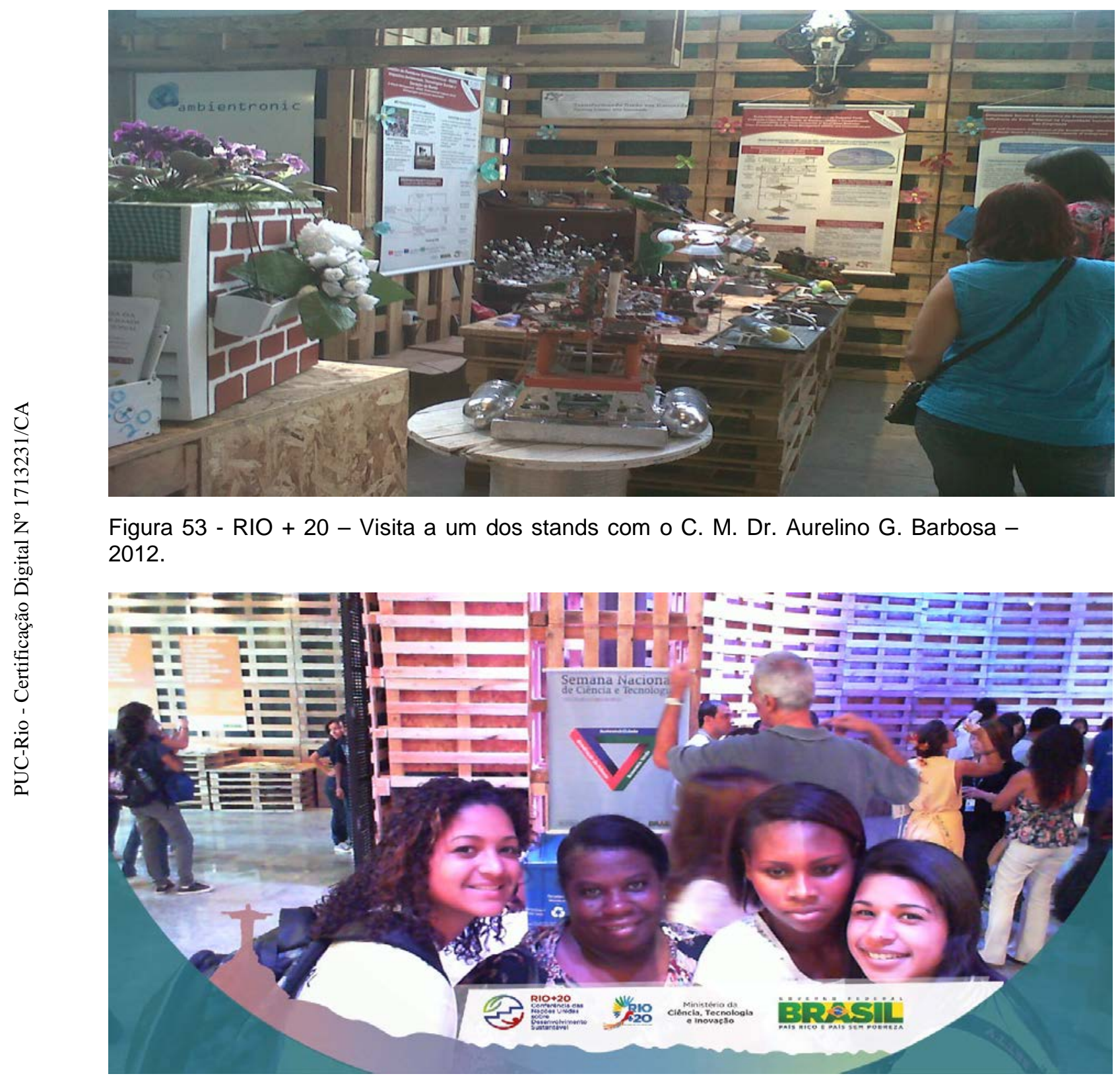

Figura 54 - Passeio a Rio + 20 - C. M. Dr. Aurelino G. Barbosa - 2012. 


\section{C - VISITAÇÃO A SÃO JOÃO MARCOS}

O passeio a São João Marcos foi uma idealização do professor de história Geraldo Miguel (in memorian) que me convidou para acompanhá-lo devido ao interesse que tenho pela aprendizagem diversificada para o desenvolvimento da leitura e da escrita junto aos alunos, e também tinha como interesse a integração e socialização desses alunos. Esse passeio foi feito com o $6^{\circ}$ ano (antiga $5^{\mathrm{a}}$ série) que visava à ampliação dos conhecimentos desses alunos da história do entorno do município de Piraí, e da implantação da Represa de Piraí pela Light.

Contamos também com um guia que nos acompanhou durante toda a visitação, e que forneceu a nós professores o folheto informativo de toda a história da fazenda, e explicou para os alunos como se deu os fatos no limiar da história, caminhando conosco e explicando toda a história.

Segundo o informativo a Fazenda de Santo Antônio da Olaria, era de propriedade de Hilário Nogueira que no dia seguinte saiu dali levando os dois jovens filhos do fazendeiro, Luiz e Cassiano Ramos Nogueira, para integrar uma improvisada Guarda de Honra e acompanhá-lo até São Paulo para realizar o intento que planejara: proclamar a Independência do Brasil. A história diz que foi na tarde de uma quinta-feira, 15 de agosto de 1822, que Dom Pedro I chegou em uma fazenda onde hoje é o município de Rio Claro (RJ).

A fazenda em questão ficava na Vila de São João do Príncipe. Que não parou de crescer. Virou a cidade de São João Marcos. Uma cidade de destaque no Estado, com hospital, clubes e até um teatro onde se apresentava, entre outros, o famoso ator e encenador João Caetano. Virou também o maior produtor de café do país e ponto de parada no eixo Rio-São Paulo.

Imperadores e nobres, além dos posteriores figurões da República, se reuniam no local, especialmente na Fazenda Olaria, que depois passou à propriedade de Joaquim Breves - então o homem mais rico do país - que também integrou a Guarda de Honra de Dom Pedro I e presenciou o grito da Independência.

São João Marcos foi a primeira cidade do país a ser tombada pelo SPHAN (Serviço do Patrimônio Histórico e Artístico Nacional) em 1939. 
E também a primeira e única a ser destombada: desta vez por Decreto-Lei do então ditador Getúlio Vargas, que revogou o tombamento e entregou a cidade para ser destruída, casa por casa, pela Light.

Motivo? Ampliar a represa de Piraí (Represa de Ribeirão das Lajes).

Duzentos anos de História foram, literalmente, por água abaixo.

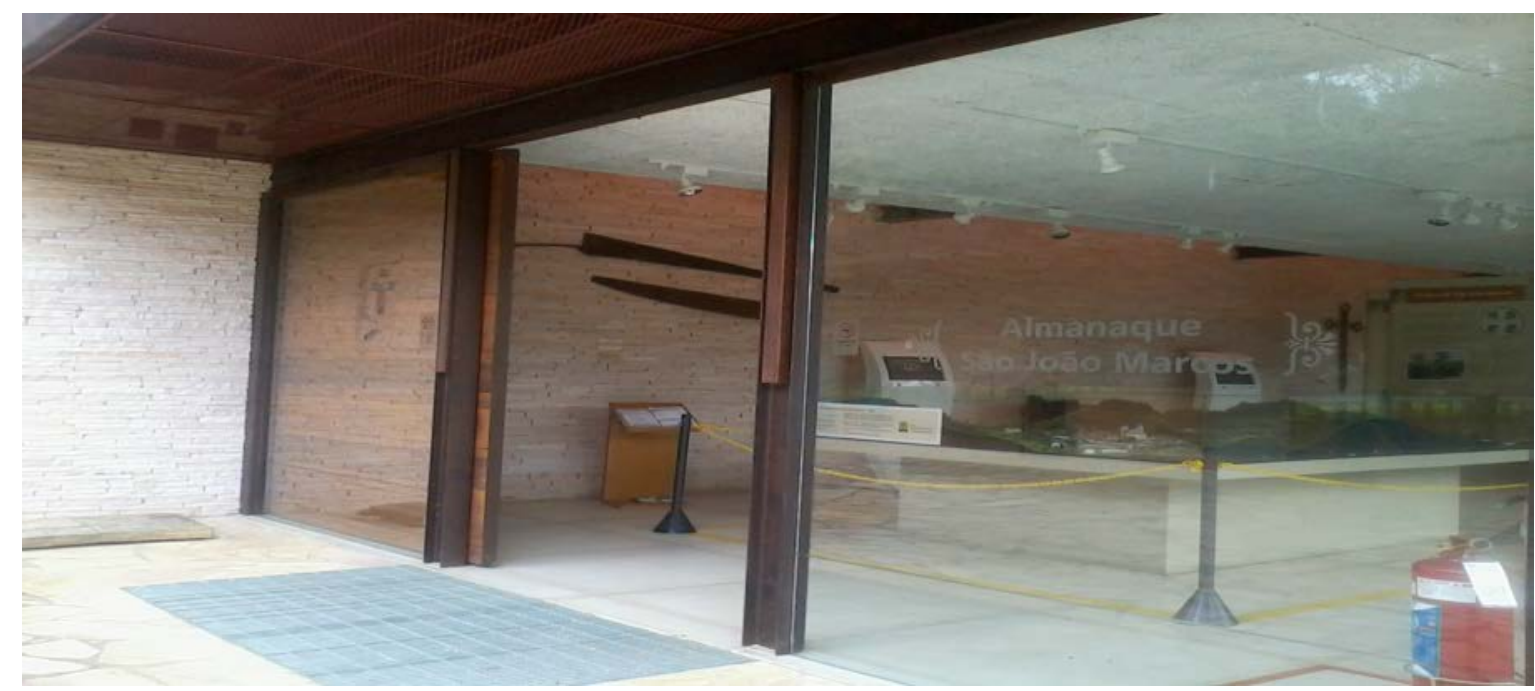

Figura 55 - Passeio com o $6^{\circ}$ ano ao monumento de São João Marcos.

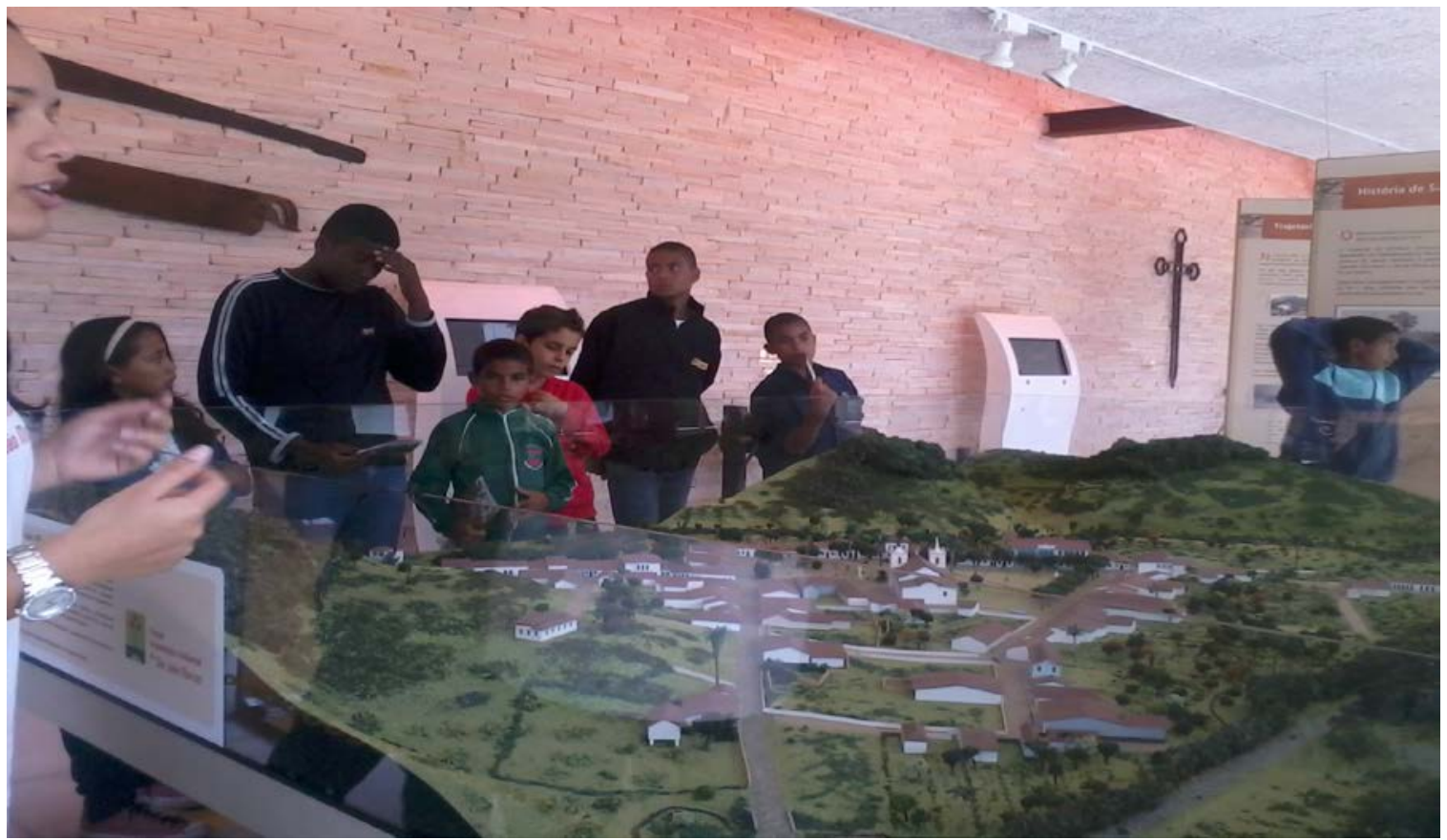

Figura 56 - Maket da cidade de São João Marcos antes da destruição. 


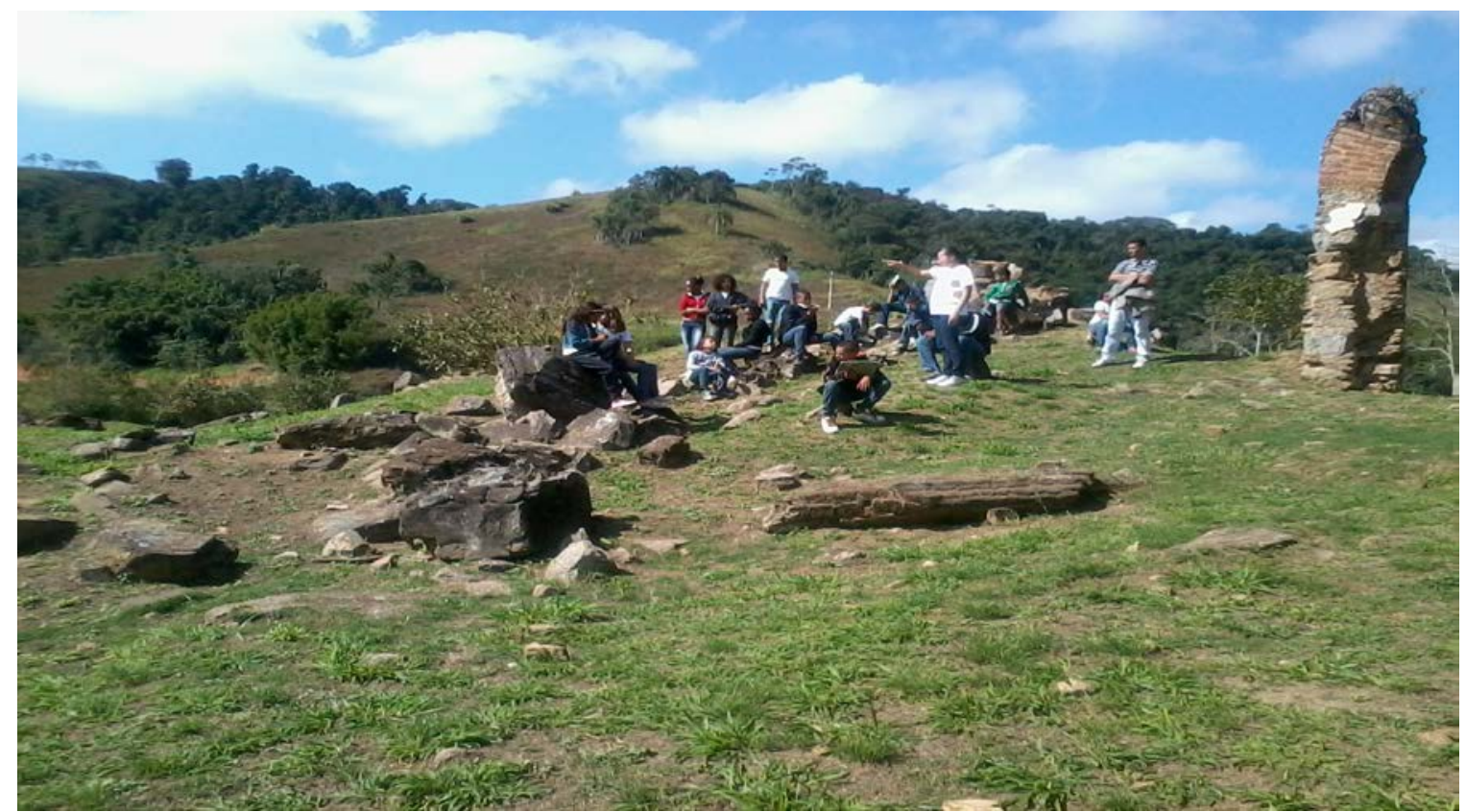

Figura 57 - Alunos e professores caminhando junto como o guia turístico pelos destroços da cidade.

\section{D - PASSEIO A PETRÓPOLIS}

Esse passeio foi feito por mim em parceria com o professor de História Geraldo Miguel (in memorian), que primeiro desenvolvia na sala com os alunos a história da cidade, e depois em forma de projeto escrevíamos a intenção do passeio para que houvesse a liberação da saída à visitação pela Secretaria de Educação e pela escola. A história da cidade de Petrópolis que se encontra na Serra da Estrela, pelo que se pode observar era desconhecida para os nossos alunos como o era também pelos colonizadores portugueses nos primeiros 200 anos de colonização, salvo por alguma expedição exploratória para tomar posse de sesmarias. Os historiadores afirmam que esse fato ocorria devido ao enorme paredão montanhoso de mais de $1000 \mathrm{~m}$ de altura que tinha que ser vencido para se chegar até lá; e também pela presença dos bravios índios Coroados que habitavam serra acima. Ali não havia atividade econômica. Somente quando os bandeirantes paulistas descobriram ouro nas Minas Gerais é que foi aberto o Caminho Novo, em 1704, para facilitar a viagem até as vilas mineradoras. O caminho era "novo", porque havia um outro o "velho”, a variante do caminho novo, passa pelo alto da serra onde hoje está a cidade desde meados dos anos 1600, muito longo e de difícil trânsito, aberto pelos próprios bandeirantes, constituído de trilhas e picadas até as minas de ouro. 
Atualmente, Petrópolis se tornou um dos lugares mais visitados do Rio de janeiro, tanto como ponto Turístico, quanto por ser uma das cidades que possui festas muito conhecidas e possui a famosa Rua Tereza que comercializa roupas de diferentes comerciantes.

Esse passeio foi muito importante para o entrosamento e socialização dos alunos da EJA e do Ensino Médio do Colégio Municipal Doutor Aurelino G. Barbosa, conhecer através de visitação a história que permeia a história do Brasil.

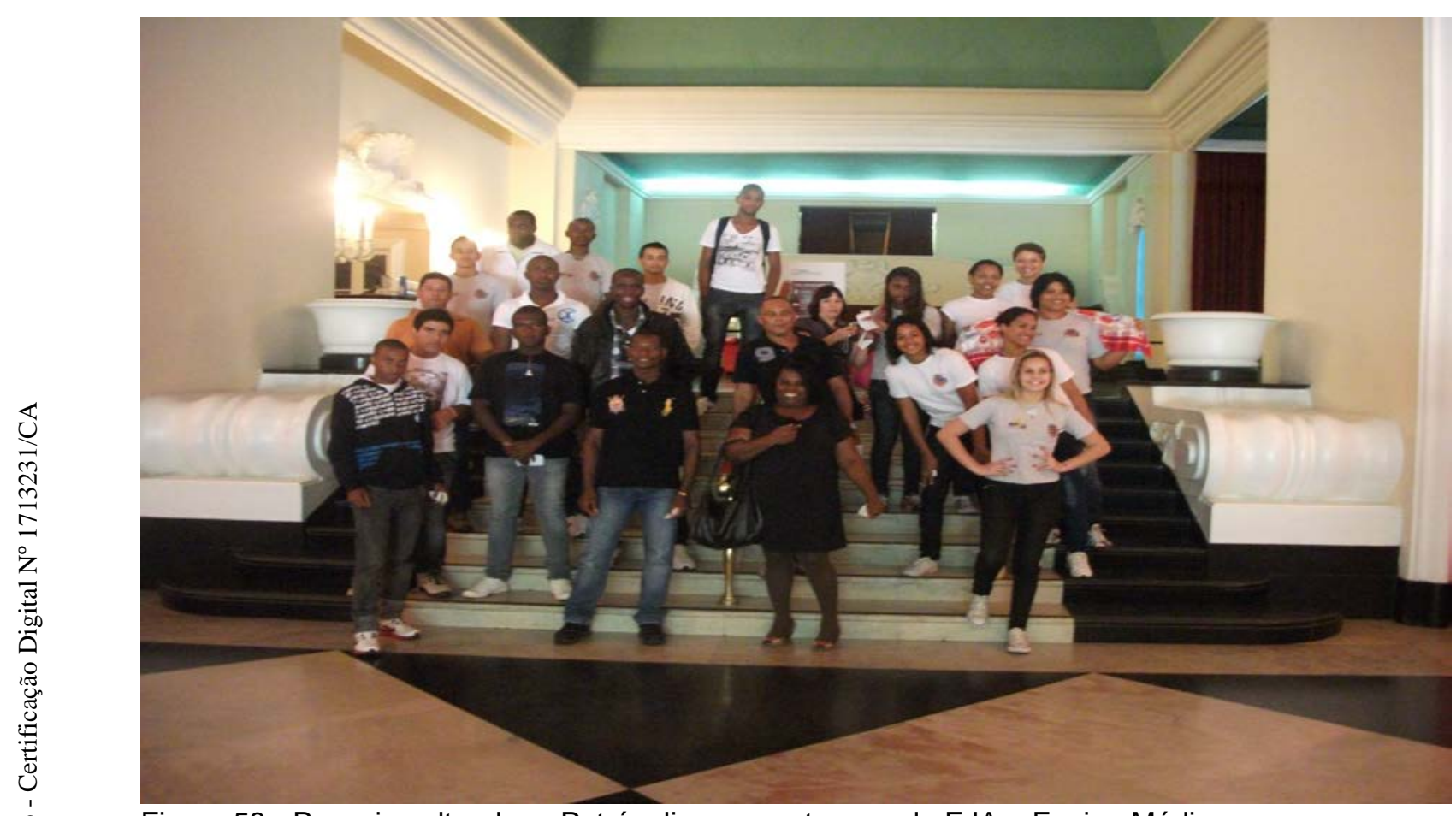

Figura 58 - Passeio cultural em Petrópolis com as turmas de EJA e Ensino Médio. 


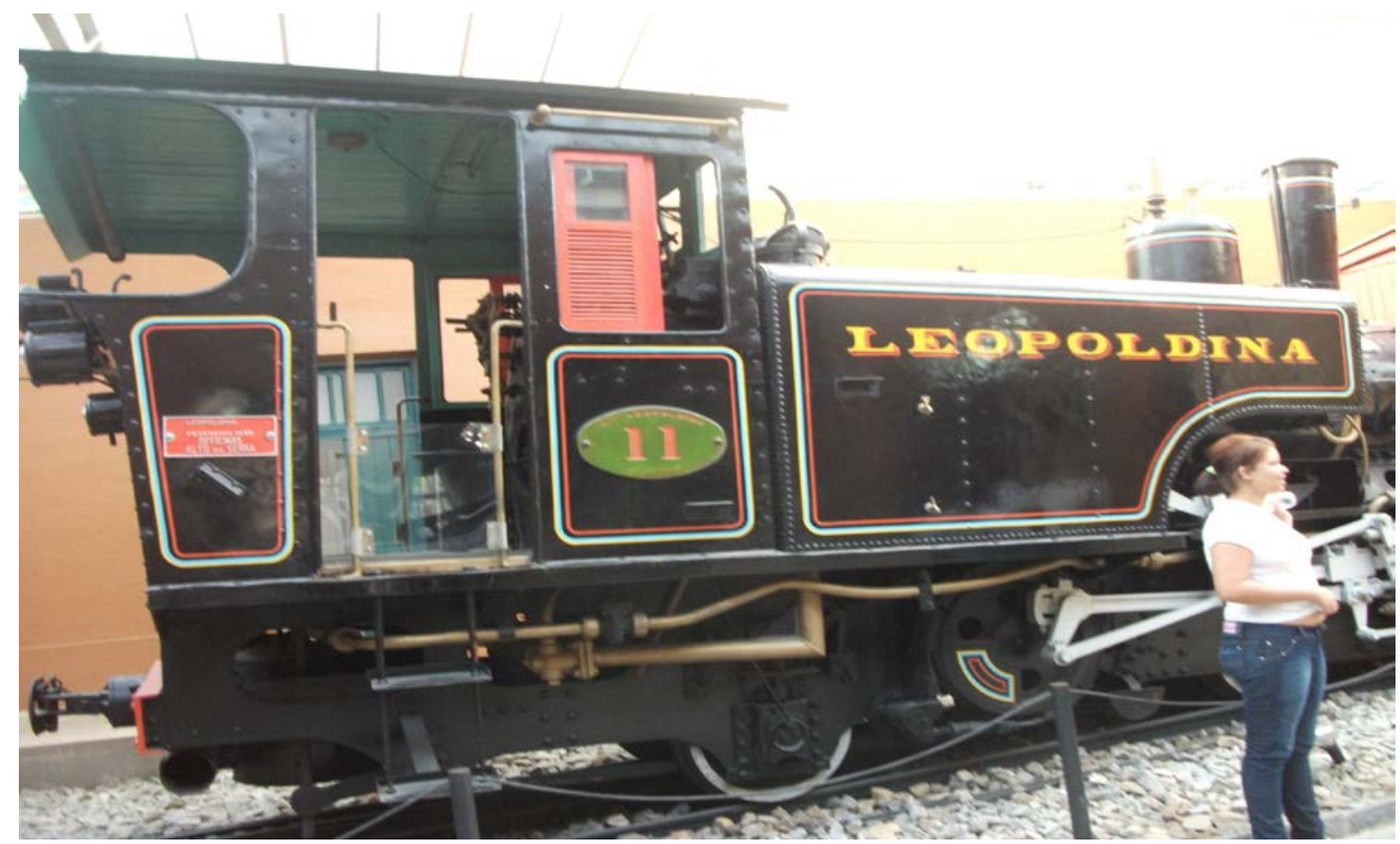

Figura 59 - Locomotiva Princesa Leopoldina em Petrópolis.

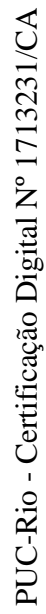

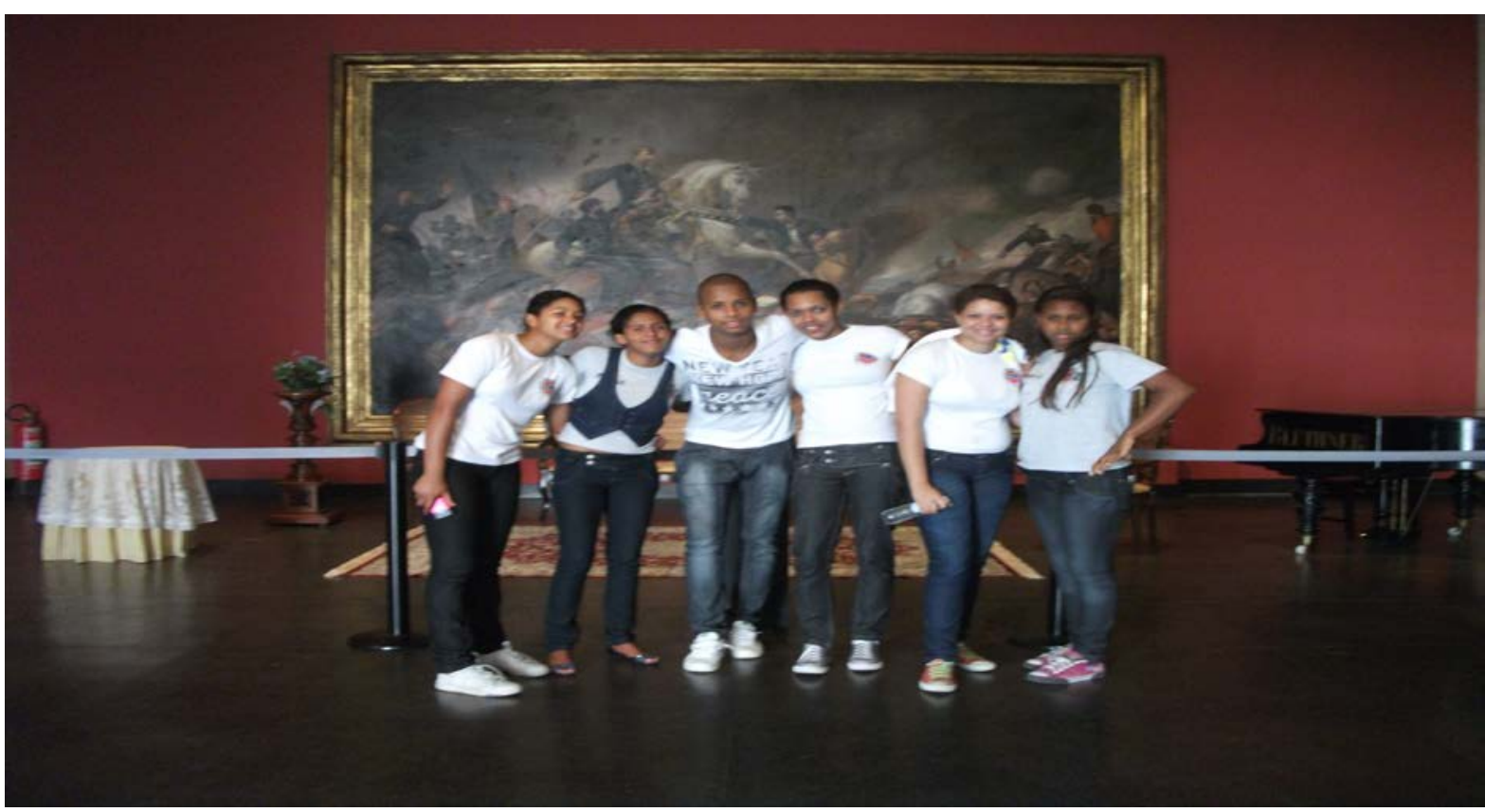

Figura 60 - Visitação ao Museu de Petrópolis. 


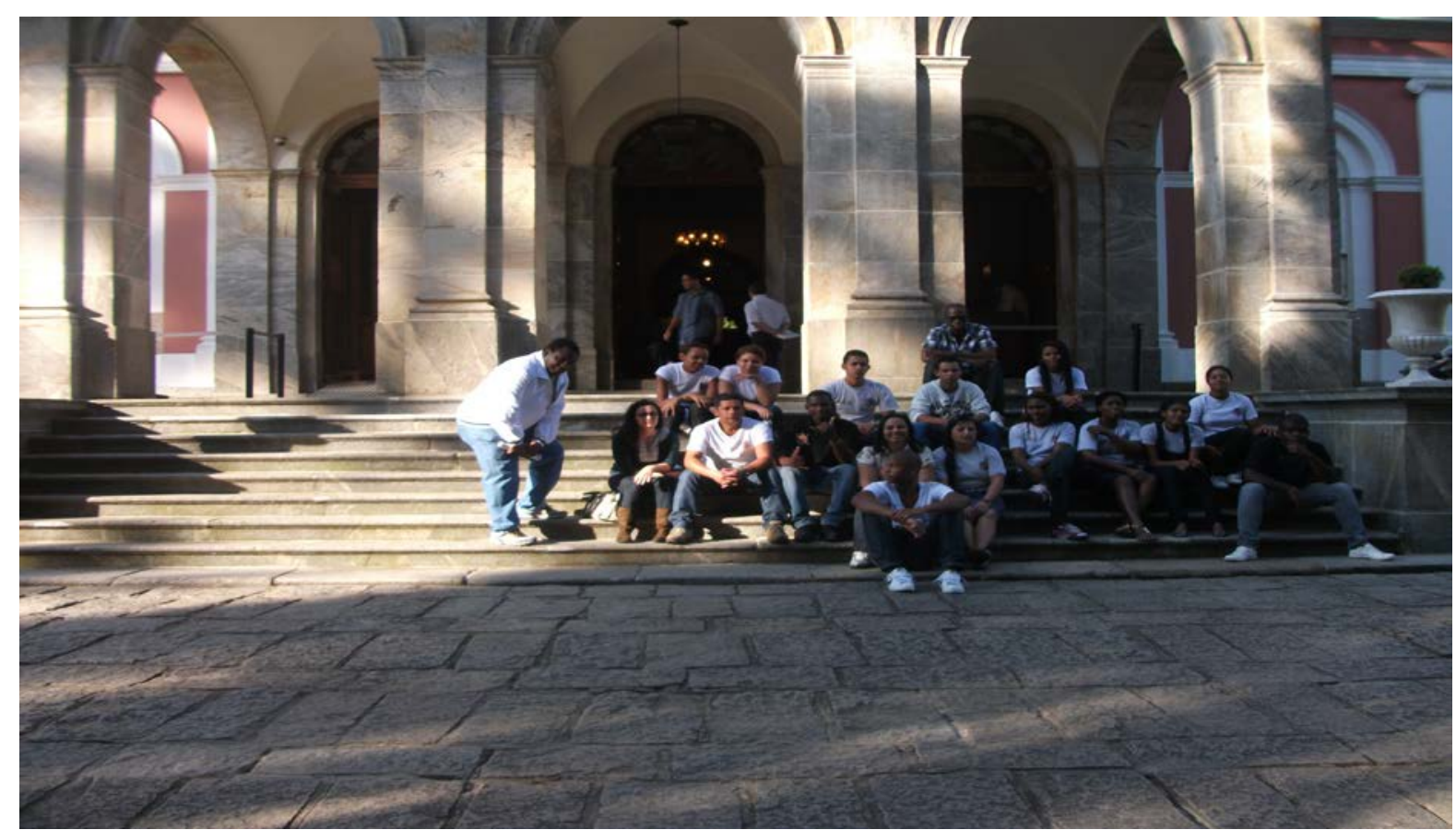

Figura 61 - Visitação ao museu de Petrópolis.

\section{2}

\section{Enriquecendo o conhecimento - danças, peças teatrais, criação de paródias}

Ranciere (2015, p.11) nos fala da "partilha do sensível”, enquanto cerne da política, isso nos remete a uma determinada estética da política, fato esse que pode ser percebido nos projetos que são desenvolvidos no espaço escolar. Muitos dos eventos desenvolvidos por professores e alunos, nos trazem a multiplicação dos discursos através das diferentes vozes que se fazem presentes, mesmo que essas vozes de maneira velada denunciem a crise que a Arte no Brasil esta sofrendo, pois uma boa parte da sociedade não tem acesso a um espetáculo; seja ele teatral, cineasta, determinados shows e espetáculos.

É através das parcas imagens que são reproduzidas e produzidas como espetáculo do outro no entre lugares que tanto nos fala Silviano Santiago, há um grito de socorro da sociedade desabonada de seus direitos as suas vozes. As imagens são indicações suficientes de que atualmente, é no terreno estético que prossegue uma batalha centrada nas promessas da emancipação e nas ilusões e desilusões da história. 


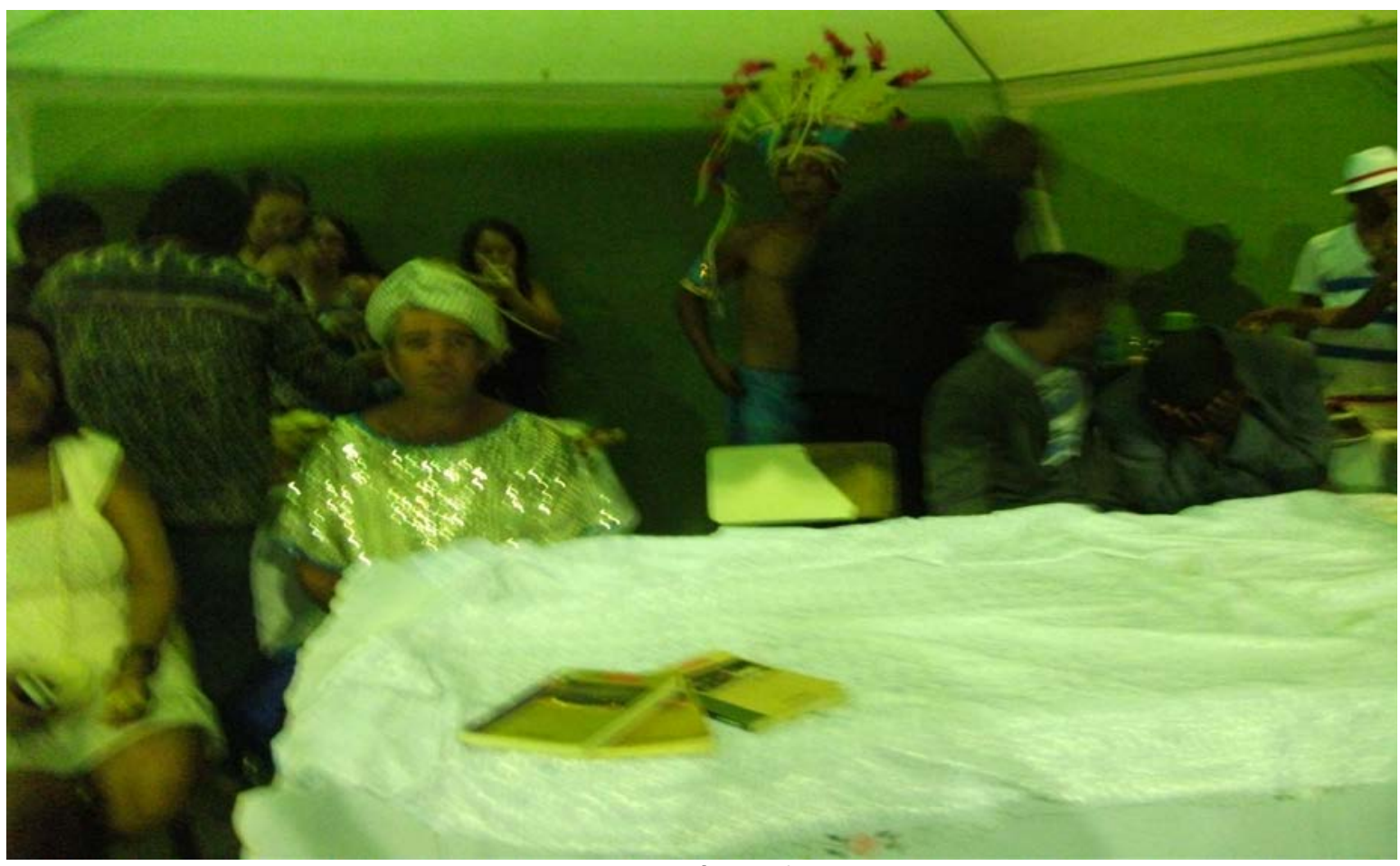

Figura 62 - Representação da religiosidade de raízes africanas - E.M. Panaro Figueira.

Apesar do apoio político em determinados trabalhos e eventos, a arte representada aqui é testemunho do encontro com o irrepresentável que tem a capacidade de desconcertar todo o pensamento - pois a criação desses trabalhos e eventos é feito de forma improvisada e amadora, pois na maioria das vezes não se possui subsídios o bastante para as suas realizações, mas mesmo assim a criatividade entre professores e alunos em sua criação interdisciplinar, perpassam as poucas possibilidades que se tem - sendo assim, esse torna-se um testemunho contra a arrogância e a grande tentativa estético-política do Devir-Mundo do pensamento, de diminuir a criatividade no espaço escolar. 


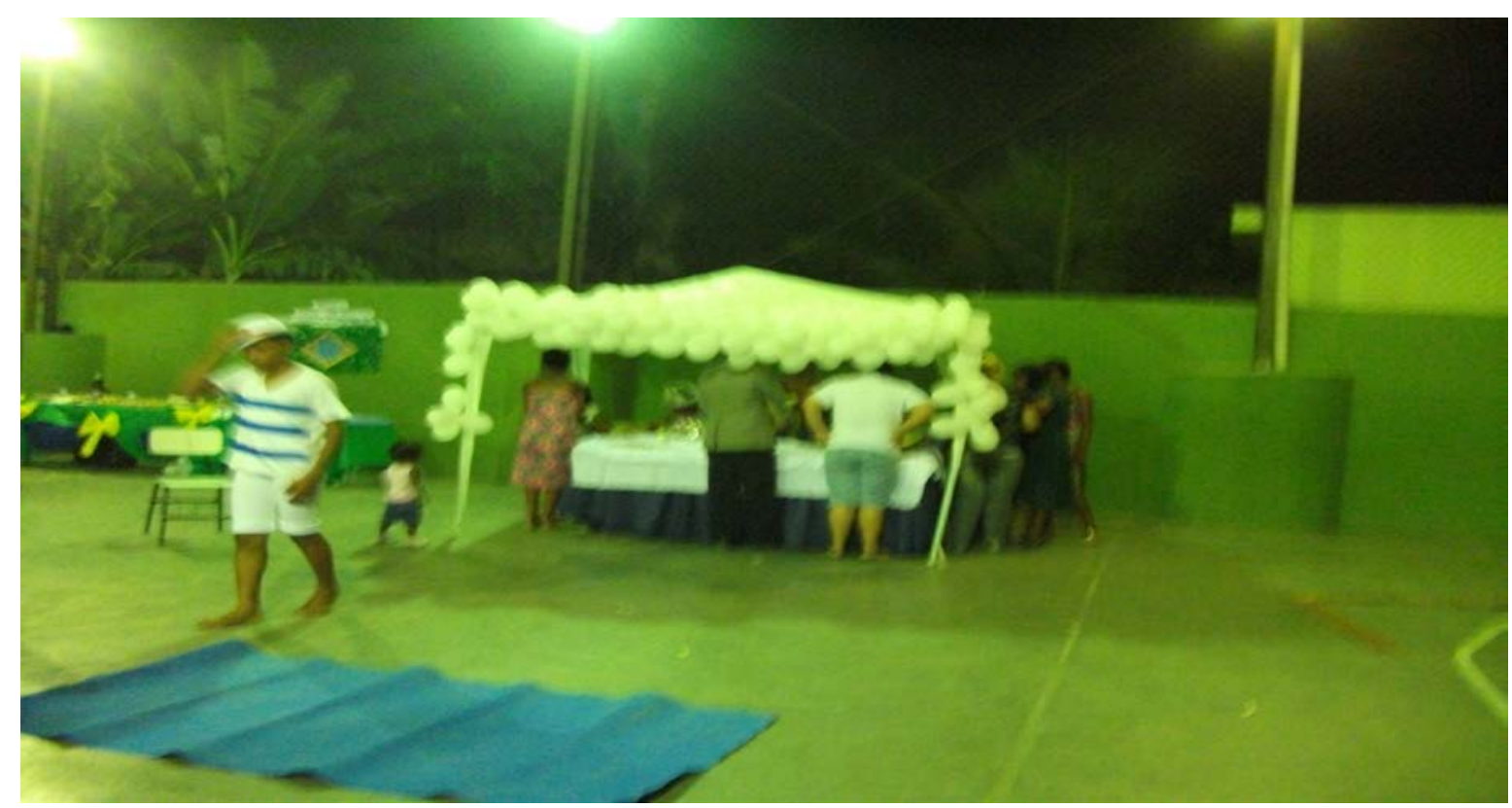

Figura 63 - Aluno da EJA da E. M. Panaro Figueira em uma representação de dança africana.

Porque parte-se do princípio que uma representação se adéqua a alguns parâmetros estéticos prévios. Portanto, tais parâmetros em função do olhar de cada um, e são informados por suas posições socioeconômicas e referências culturais, mas essa estética quando é feita a partir do trabalho de alunos que não sabem o que é a estética, mas têm uma forma peculiar de criar entre si, e desenvolvem trabalhos e eventos que vão além do que se espera. Essa é uma forma peculiar de se diferenciar a Arte em si.

Coloca-se em cheque a parte teórica, trazendo como pano de fundo a arte remetida a seus efeitos sobre a sensibilidade de cada indivíduo. Esse pensamento das artes seria um modo de articulação entre diferentes maneiras de fazer, as formas de visibilidade dessas maneiras de fazer, e modos de pensabilidade de suas relações, dando lugar a uma determinada ideia da efetividade do pensamento. Observando assim, as articulações dessa forma de pensamento estético das artes, os seus modos de transformações do fazer artísticos e estéticos dessa arte, com as práticas dos alunos, podendo observar que a concepção de mundo deles, que na concepção de um mundo que para muitos é entendível, para eles é entendível apenas de forma representativa...

Os discursos contemporâneos nos levam a simples realidade das Práticas da Arte, que possuem determinados critérios de apreciação.

Para Ranciere (2015, p.14): 
“A conexão dessas 'simples práticas' com modos de discurso, formas de vida, ideias do pensamento e figuras da comunidade não é fruto de nenhum desvio maléfico. Em compensação, o esforço para pensá-la implica abandonar a pobre dramaturgia do fim e do retorno, que não cessa de ocupar o terreno da arte, da política e de todo objeto de pensamento".

O questionamento que se tem leva a tentar entender o que no meio político para nós professores pode ser pensado como 'partilha do sensível' a partir do pensamento capitalista que usa a fruição versus trabalho, que faz do outro um mero empregado sem direitos trabalhistas, por isso a expressão 'feudal' vem permeada pelo modo de ver do senhor, em que esse engloba a chave da junção necessária entre as práticas estéticas e as práticas poéticas?

Ranciere denomina 'partilha do sensível' o sistema de evidências sensíveis que revela ao mesmo tempo, a existência de um senso comum que englobaria todos os feitos que são considerados comuns a todos sem distinção de pessoa e dos recortes que nele definem lugares e suas respectivas partes. Despertando assim, a sensibilidade estética do aluno de olhar para o mundo "ver o belo" como experiência de vida, e usá-lo no espaço escolar com distanciamento da sua representatividade de mundo através de histórias representadas em peças teatrais.

Sendo assim, para Ranciere (2015, p. 13) uma 'partilha do sensível’ fixa portanto, ao mesmo tempo, um comum partilhado e suas partes exclusivas. Essa repartição das partes e dos lugares funda numa partilha de espaços, tempos e tipos de atividades que determina propriamente a maneira como um comum se presta à participação e como uns e outros tomam parte nessa partilha. Nas escolas públicas, essa partilha é feita através das representações orquestradas por professores e alunos em busca de uma unidade. Todas as turmas participam desenvolvendo algum tipo de trabalho; há aqueles que não querem desenvolver esse trabalho que na maioria das vezes são danças coletivas e individuais, ai entra em ação a parte que envolve a partilha dos alimentos, cada um doa o que pode, e se torna um evento onde a coletividade faz juz aos trabalhos desenvolvidos. A dança é a principal forma que se tem dessas pessoas serem vistas, serem aplaudidas e serem valorizadas... Infelizmente muitos deles continuarão no anonimato, pois a vida a eles não oferecem nada, além do trabalho árduo. O aluno que frequenta a EJA, na maioria das vezes trabalha o dia inteiro. Mas, mesmo assim os trabalhos por eles desenvolvidos e apresentados, são maravilhosos... 


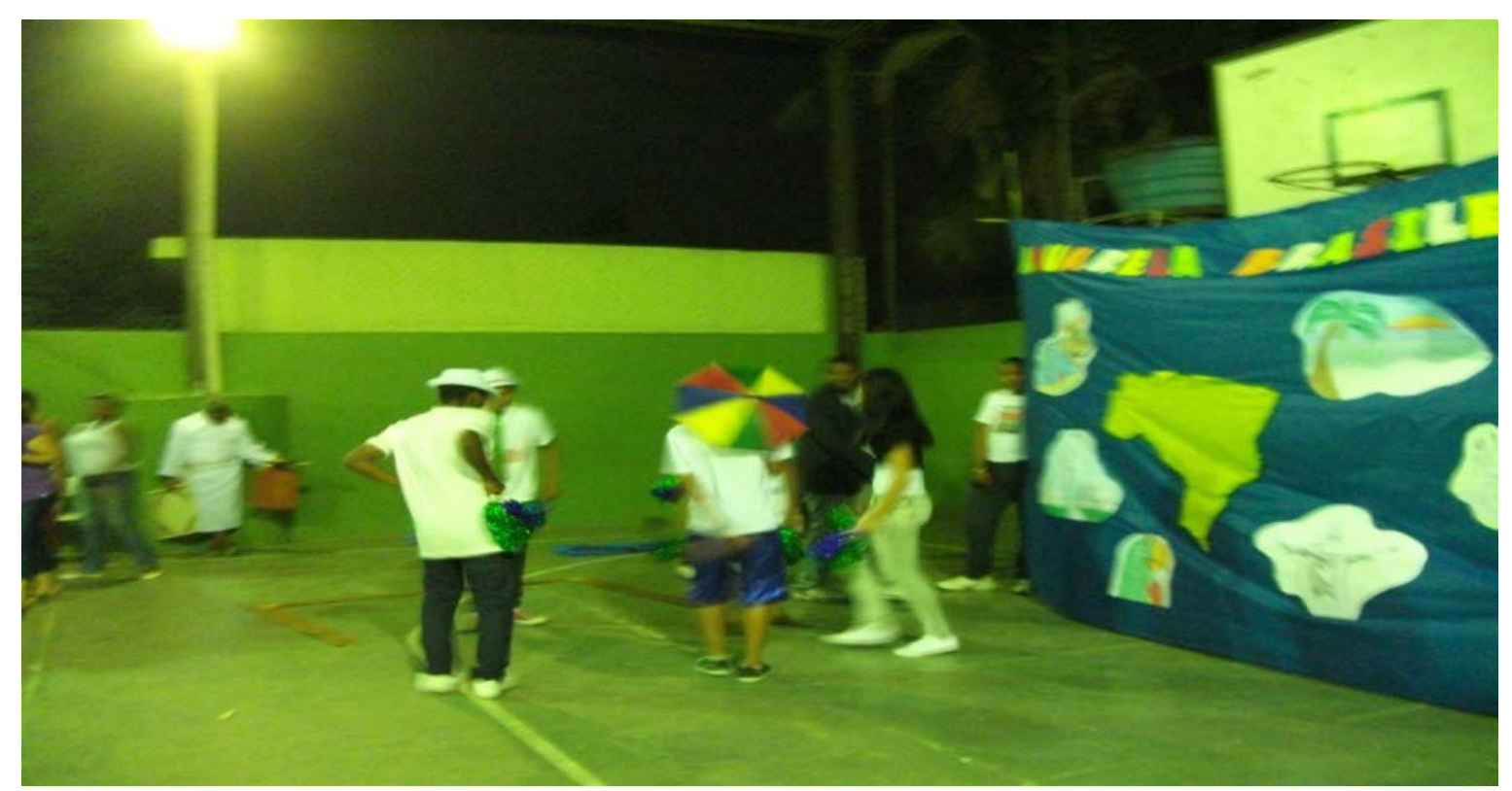

Figura 64 - Representação de danças folclóricas de diferentes regiões do Brasil - EJA Panaro Figueira.

Aristóteles em sua sábia observação do ‘cidadão’, afirma que esse até toma parte no fato de governar e ser governado. Mas, para ele uma outra forma de partilha precede esse tomar parte: aquela que determina os que tomam parte. Em suas bases políticas ele afirma que o animal falante é um animal político. O escravo mesmo que compreenda a linguagem, não a 'possui'. Os artesãos diz Platão, não podem participar das coisas comuns porque eles não têm tempo para se dedicar a outra coisa que não seja o seu trabalho. Eles não podem estar em outro lugar porque o trabalho não espera.

O lugar que o povo ocupa, é um recorte do tempo e do espaço nesse caso $o$ do visível e do invisível, da palavra e do ruído que define ao mesmo tempo o seu lugar de ocupação, e o que está em jogo na política como forma de experiência.

A voz da Escola Pública muita das vezes nos leva a compreensão do porque esta não é ouvida, pois o que cabe no meio político é o lugar daquele que pode ver, e do que ele pode dizer sobre o que é visto, de quem tem competência para ver e qualidade para falar ou dizer algo. Como essa voz á apagada pelo ressoar do que a ele pode ser levado enquanto aparato para uma visão de mundo mais amplo, do espaço que ele ocupa enquanto indivíduo social e do seu possível tempo.

Sendo assim, a partir dessa estética, surgem as 'práticas estéticas’ que dão visibilidade as práticas de artes, dos lugares que ocupam, do que 'fazem' no que diz respeito ao como fazem. 
As práticas artísticas desenvolvidas por cidadãos comuns que fazem parte de comunidades periféricas, em busca de aprimorar sua visibilidade das práticas da arte, do lugar que ocupam, do que 'fazem' no que diz respeito ao comum. As práticas artísticas são maneiras de fazer e nas suas relações com maneiras de ser de cada um e suas formas de visibilidade.

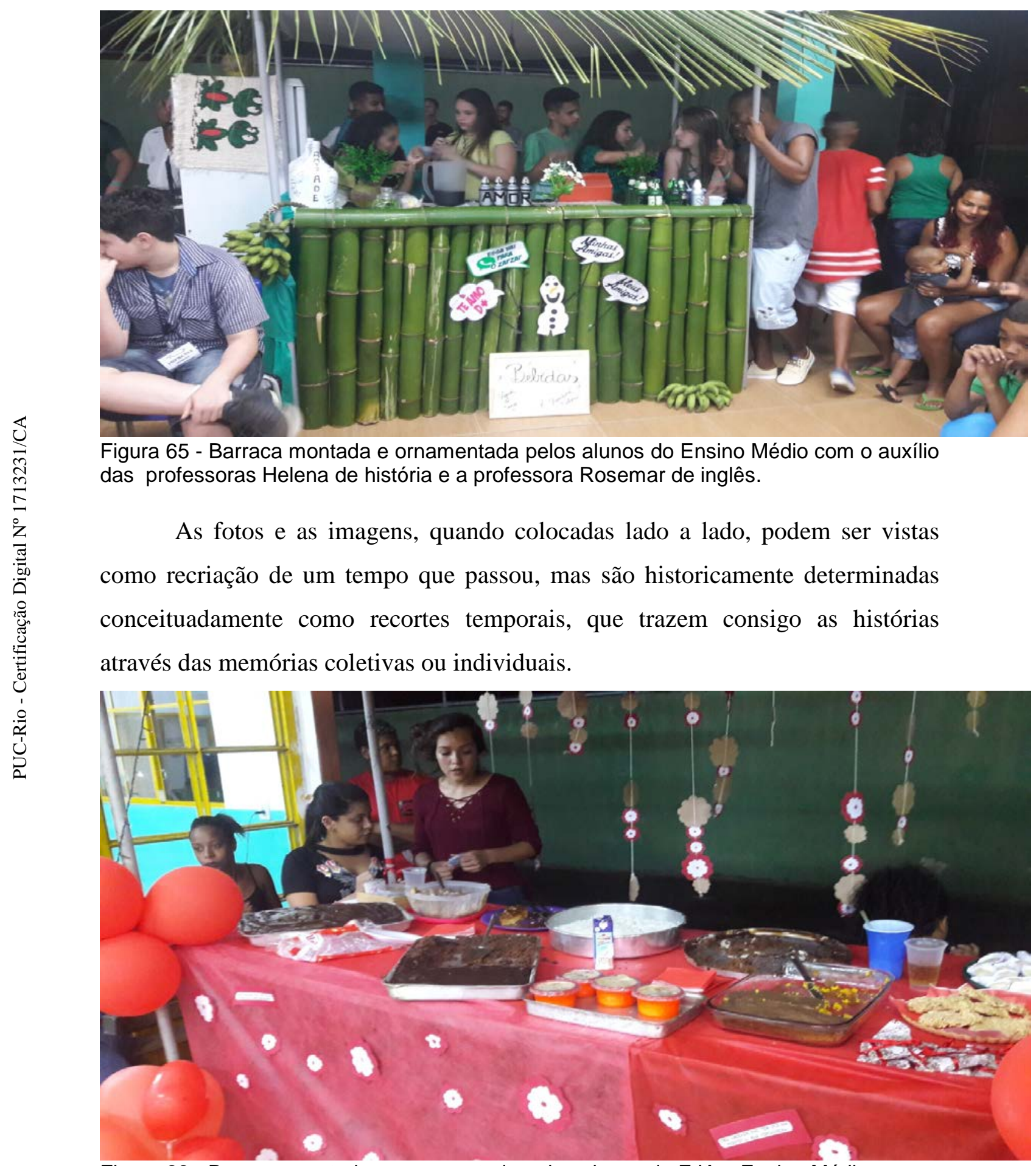

Figura 66 - Barraca montada e ornamentada pelos alunos de EJA e Ensino Médio. 
A modernidade usada como um disparador de discursos que colocam os maiorais no campo das artes em um mesmo patamar, esse fato deve ser visto de outra forma, porque há uma necessidade de separá-los, devido a pouca consistência dessas noções, pois não implica uma adesão aos discursos contemporâneos de retorno à simples realidade das práticas da arte e de seus critérios de apreciação por aqueles que vivem essa arte de forma representativa.

O que se pode perceber é que ela é sim uma forma que o povo tem de apresentar seus trabalhos, sejam manuais artísticos, teatrais, através do espaço que a eles são ofertados. Na maioria das vezes isso ocorre quando estes fazem parte de atividades sejam em uma igreja, em uma praça, em uma escola... Pode-se observar isso nas fotos que seguem da cantata de natal elaborada pelos professores da Educação Infantil e Ensino Fundamental I e II com o auxílio dos professores de música. Foi apresentada danças performáticas, peças teatrais... A comunidade é parceira nesses eventos, o auxílio do poder público também é crucial.

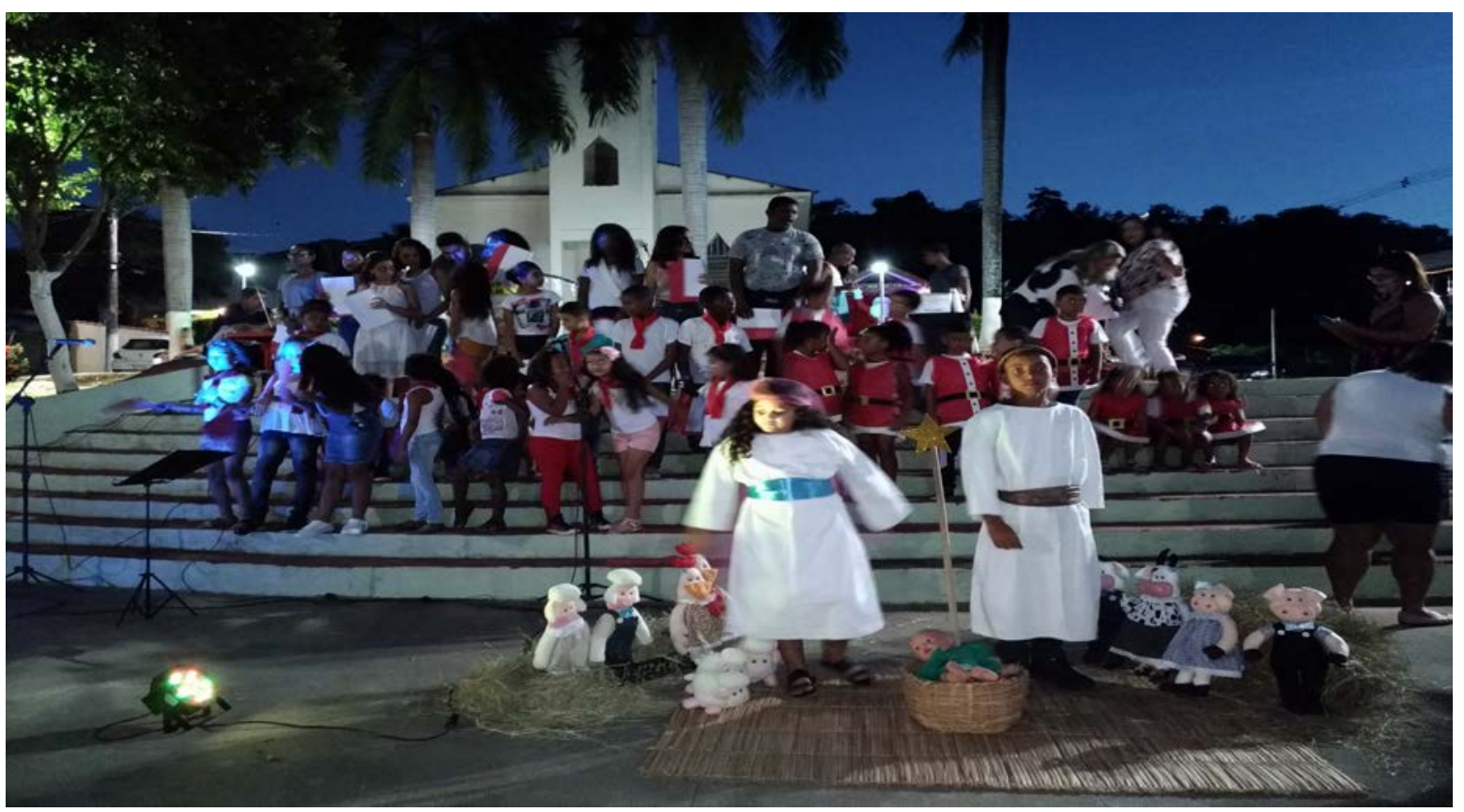

Figura 67 - Ensino Fundamental I na apresentação na cantata de natal na praça - 2018. 


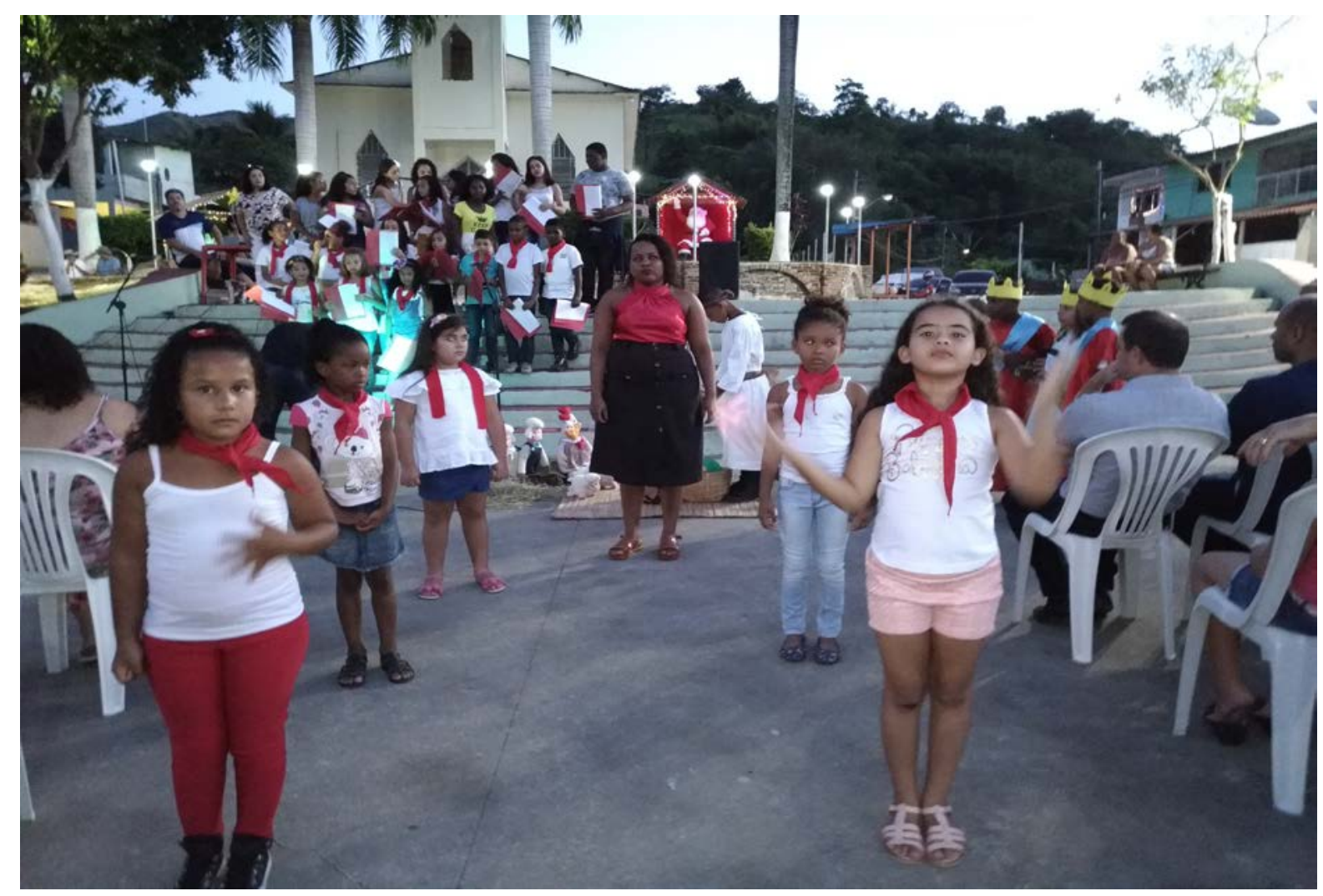

Figura 68 - Ensino Fundamental I em uma representação na cantata de natal na praça $-2018$.

A partir daí surge à voz do povo da periferia através dessas apresentações e exposições... Ainda há escolas públicas que representam bem o seu papel social...

O caminho que nos traz até aqui, nos reporta às práticas pedagógicas realizadas ao longo de todos esses anos exercendo a profissão na Educação: elas servem para valorizar tradições calcadas na coletividade, realçam a alegria que ocorre nos eventos em que colegas prestigiam outros colegas, seja na prática de declamação de poemas e poesias, de peças teatrais, saraus literários, nas danças apresentadas em grupos, como nos trabalhos efetuados extraclasse que constituem formas de promoção de aprendizagem diferenciada. Esses eventos têm como finalidade proporcionar aos alunos uma aprendizagem que tenha a prática do trabalho em grupo, como fundamento para futuras apresentações em Seminários, peças, shows... Assim como, no plano individual que se adquiram valores sociais e morais, que levarão para a vida. 


\section{3}

\section{Pedagoginga na educação - as danças}

Retomando a fala de Pedagoginga, Allan da Rosa nos transporta a essa que seria essa "Ginga”, que se tornou vigente através das danças folclóricas que fazem parte da cultura brasileira, mas que em sua inventividade os alunos no espaço escolar, quando em um trabalho maior nos aparece com danças regionais que são apresentadas em diferentes momentos com algumas peculiaridades criadas por eles mesmos, que vão além do que se pensa com relação a cultura, e em outros espaços que vão além dos muros da escola.

Surge assim a perspectiva de uma 'Educação transformadora', pois há décadas que se buscam métodos e práticas adequadas ao aprendizado de Jovens e Adultos. Pode-se nessa perspectiva citar Paulo Freire (1979, p. 72), que nos leva a entender que:

\footnotetext{
"Uma alfabetização não pode ser feita de cima para baixo, nem de fora para dentro, como uma doação ou uma exposição, mas de dentro para fora pelo próprio sujeito, somente ajustado pelo educador. Talvez essa seja a razão pela qual se vive em busca de um método que seja capaz de fazer do educando um instrumento para a efetivação de diferentes saberes com o auxílio do educador, para que se possa identificar, como claramente observou um jovem sociólogo brasileiro (Celso Beisiegel), como se relaciona o conteúdo da aprendizagem com o processo de aprendizagem. Por essa razão, não se deve acreditar nas cartilhas que pretendem fazer uma montagem de sinalização gráfica como uma doação e que reduzem o sujeito analfabeto mais à condição de objeto de alfabetização do que de sujeito da mesma” (FREIRE, 1979, p.72).
}

Paulo Freire (1979) ao tomar o educando como sujeito de sua aprendizagem, propunha uma ação educativa que não negasse a sua cultura, mas que fosse se transformando através do diálogo, da criatividade, da integração, da construção e do conhecimento. Com isso pode-se perceber que o trabalho interdisciplinar de propagação da cultura de diferentes formas traz a efetivação dessa educação tão difundida nos livros educativos que falam de práticas pedagógicas, mesmo que essas estejam apenas idealizadas nesses livros.

Por isso, tornou-se interessante a leitura do livro de Alan da Rosa que vai ao encontro de muitas das práticas que foram desenvolvidas por mim enquanto professora de escola pública, com alunos de diferentes situações econômicas, diferentes personalidades e que tinham um grande desejo de conhecer o que lhes 
era apresentado como desconhecido. Muitos desses alunos nunca haviam saído das periferias nas quais viviam; não conheciam museus, teatros, praias, cidades turísticas, shopping, grandes parques... Esse foi o caminho que encontrei para desenvolver a aprendizagem desses alunos em busca de um conhecimento criativo, dinâmico, efetivo e cristalizado pelo tempo através das memórias...

Freire (2001, p.11), ao comentar que “fazer a leitura crítica do mundo se funda numa prática educativa crescente desocultadora de verdades. Verdades cuja ocultação interessa às classes dominantes da sociedade”; esse fato por observação nos leva ao grande desafio da escola: que é saber olhar para os jovens e traduzir a essência contida neles em uma perspectiva de esperança que faça vibrar nesta etapa da vida outras possibilidades de conhecimento, para além do universo educativo formal. Com isso, devemos enquanto educadores ampliar a visão de mundo destes indivíduos dentro de uma ótica amorosa e de iguais, proporcionando um relacionamento de parceria entre escola aluno professor comunidade, auxiliados por elementos não formais (música, teatro, dança, performance, pintura e outros), elementos esses que traduzem e podem vir a compor a bagagem particular de cada um desses alunos, no espaço escolar e na sociedade enquanto cidadãos em busca de novos ideais.

Alan da Rosa em seu livro "Pedagoginga, Autonomia e Mocambagem" fala sobre a cultura da periferia associada ao trabalho de avalizar, qualificar ou autorizar a produção cultural dos artistas que se encontram na periferia por critérios sociais, econômicos e culturais.

Como pode ser visto na parte introdutória desse relato, Alan da Rosa parte da percepção de que a cultura da periferia sempre existiu, mas não tinha oportunidade de ter sua voz. Já nas escolas que são objeto dessas práticas - E. M. Panaro Figueira e C. M. Dr. Aurelino G. Barbosa, a integração cultural ocorrida nos eventos já realizados foi em alguns momentos transmitida informalmente com apresentação da cultura afro-brasileira pelos professores de Artes e História, com a criação de 'Saraus Literários' direcionados pelos professores de Língua Portuguesa, que traziam como foco poesias, poemas, contos, releituras de narrativas de literaturas escritas e descritas pelos próprios alunos, às vezes de histórias contadas por pessoas locais, que vivenciaram ou presenciaram algumas passagens desses fatos locais dando margem para esses serem contados seja por 
representação teatral, seja por performance, seja por declamação feitas no espaço escolar, tendo como espectadores comunidade escolar. A foto que segue, mostra o envolvimento dos atores que fizeram parte desses momentos. Alunos, professores, funcionários da escola se envolviam nesses eventos em busca de um interrelacionamento que vai muito além dos muros da escola. Essa dança aconteceu em uma apresentação cultural de todas as escolas do município, e foi ensaiada pelo Colégio Municipal Dr. Aurelino G. Barbosa a 'Dança do pau de fita' mostrada através da imagem que segue:

\footnotetext{
“A dança do Pau de Fitas, ou dança das fitas é uma dança folclórica coreografada originária da Europa. A coreografia desenvolve-se como uma ciranda de participantes que orbitam ao redor de um mastro central (pau) fincado no chão. O peculiar é que no topo do mastro são presas as pontas de longas fitas coloridas, cuja extremidade pendente é sustentada por cada dançante. Há variações na música e instrumentos por causa da regionalização”.
}

Fonte: https://www.curiosidadesdeubatuba.com.br/danca-da-fita/

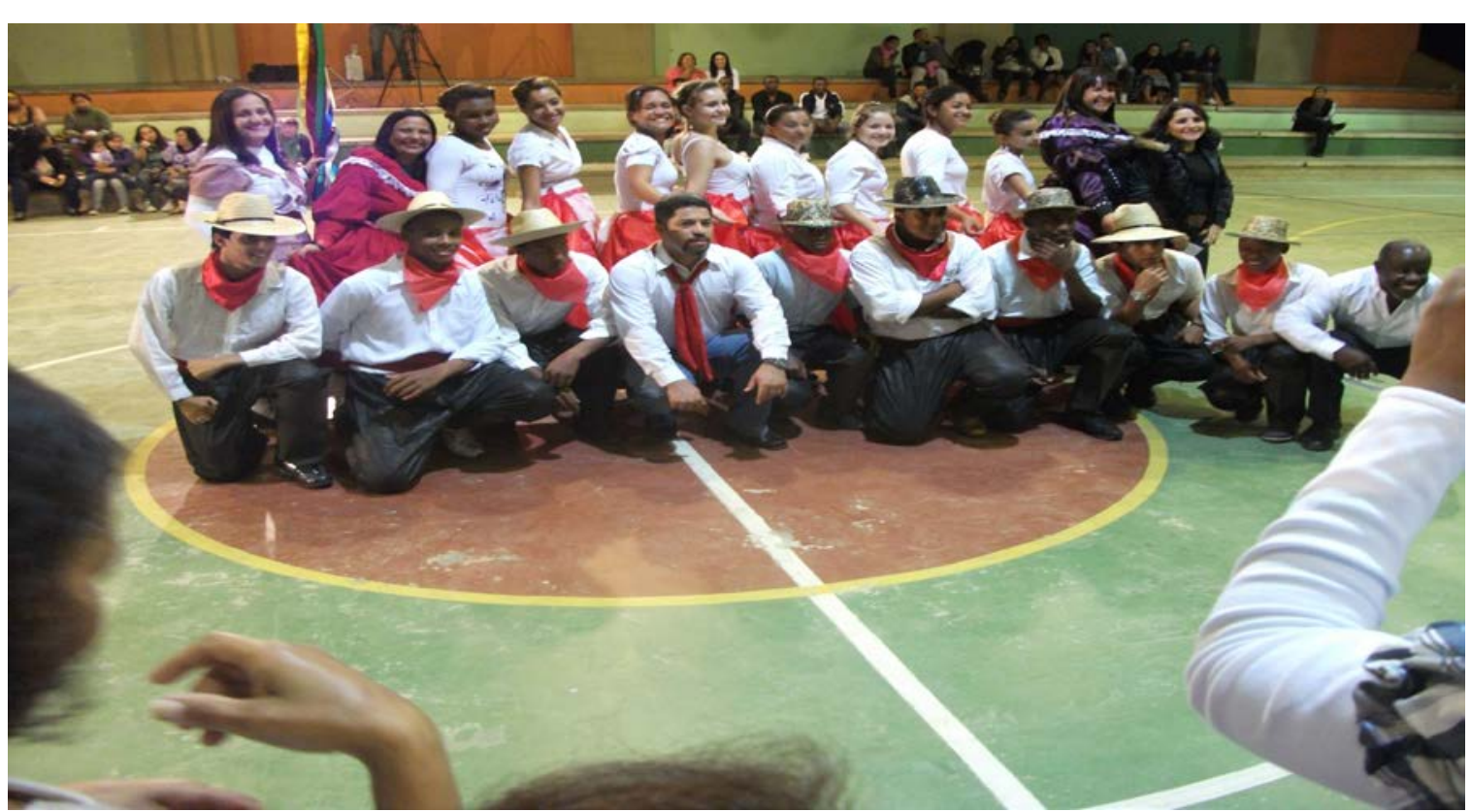

Figura 69 - Dança do pau de fita - preparação para a apresentação ao público FESTEJA.

Essas experiências são desenvolvidas a partir de pesquisas históricas que englobam o conhecimento da cultura de nossas raízes com passeios culturais a museus, parques, pontos turísticos... que ajudam a fomentar e enriquecer os trabalhos desenvolvidos pelos alunos dessas escolas públicas que se tornaram objeto desses relatos. 
Essa reflexão como se pode observar, está a serviço de uma proposta de renovação dos horizontes da Educação, na intenção de transformar vidas. Envolvendo todos os segmentos das escolas em busca de uma cultura folclórica que recrie a história da cultura brasileira oriunda dos colonizadores dessa terra.

Por ser educadora a vinte e oito anos, e ter participado de diferentes momentos dessa educação que engloba o ensino noturno, que veio tendo diferentes nomenclaturas 'Supletivo', 'Educação de adultos', mas pelas dificuldades de algumas localidades eles usaram para esses mesmos fins o MOBRAL, TELECURSO primeiro e segundo grau (ministrado de forma presencial, atendendo a necessidade da comunidade), sabe-se que eram projetos, mas devido a dificuldade na época de acesso desses alunos ao segundo grau, eles eram ministrados dentro de escolas públicas. Essa já é outra discussão para um outro momento... Foi a partir dessas vertentes é que criei aqui os relatos dessas práticas e experiências pedagógica. Esta reflexão sobre essas práticas tem contribuído muito em meu crescimento profissional enquanto professora de EJA, Ensino Fundamental e Ensino Médio de Língua Portuguesa e de Língua Inglesa.

Os trabalhos mostrados nas fotos nos reportam a diferentes momentos em que essas práticas pedagógicas ocorreram, elas serviram de motivação para que esses atores anônimos se sentissem valorizados no seu meio social, em sua comunidade... Essas práticas vão ao encontro de práticas descritas no livro de Alan da Rosa, que mesmo sendo desenvolvidas em espaços diferentes, e em um tempo bem diferente do representado, tinham o mesmo tipo de ideologia e autonomia, que era proporcionar aos alunos envolvidos a oportunidade de se tornarem visíveis através da sua arte. Essas práticas como citadas na introdução, foram desenvolvidas em parceria com diferentes educadores, diretores, coordenadores, orientadores com o auxílio dos profissionais da educação, tendo como sujeitos principais para a execução desses os alunos de EJA, Ensino Fundamental e Ensino Médio. Cada ação, cada evento trouxe consigo um aprimoramento em muitas atividades no espaço escolar. 
Figura 70 - Dança do pau de Fita - apresentação do C. M. Dr. Aurelino no Festeja de Piraí - 2011.

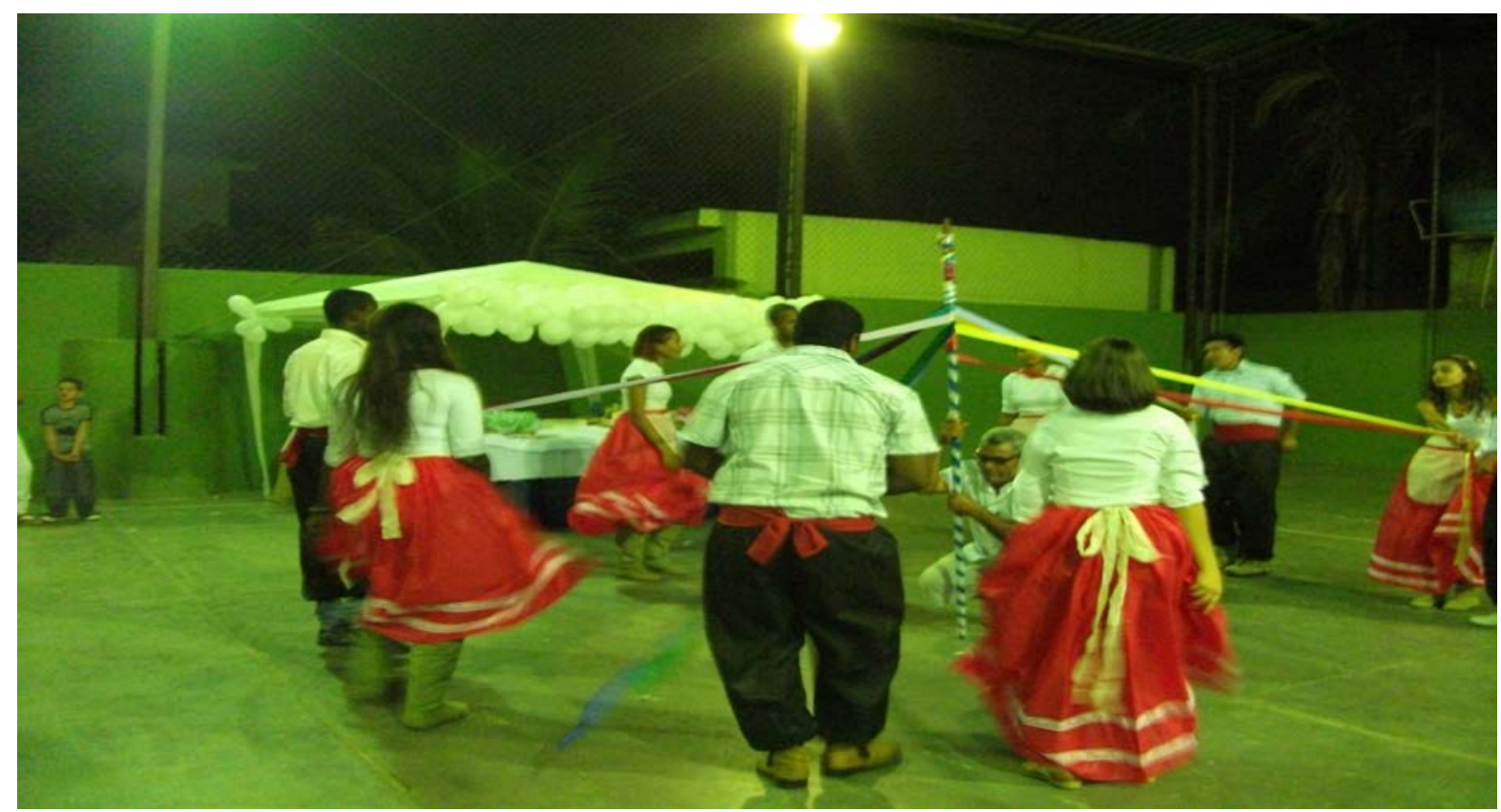

Figura 71 - Apresentação da dança do pau de fita do Colégio M. Doutor Aurelino G. Barbosa na Escola municipal Panaro Figueira levados pela professora Francinete e Celia Polati - 2011. 


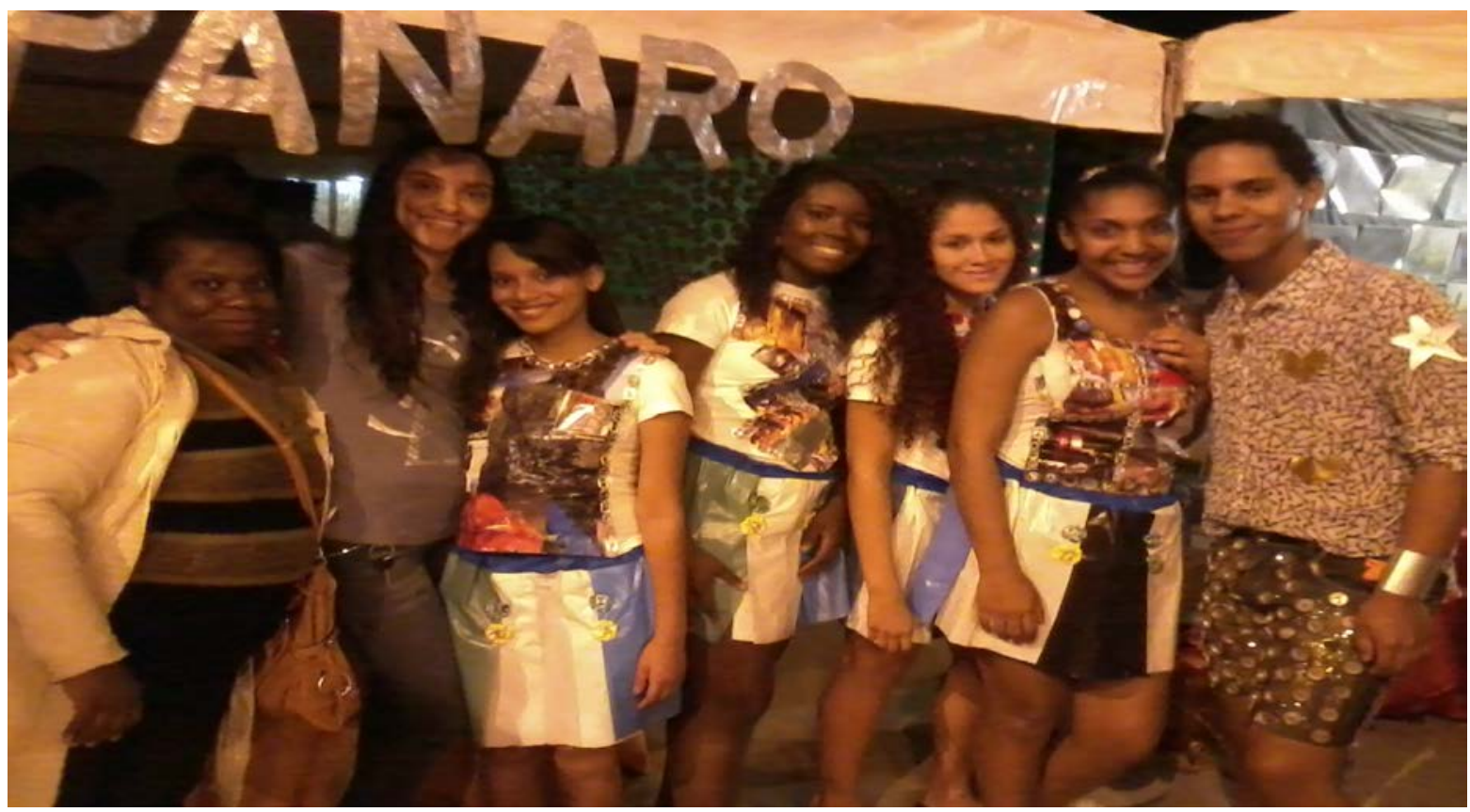

Figura 72 - Apresentação de dança da Panaro Figueira no FESTEJA de Seropédica 2012.

Uू

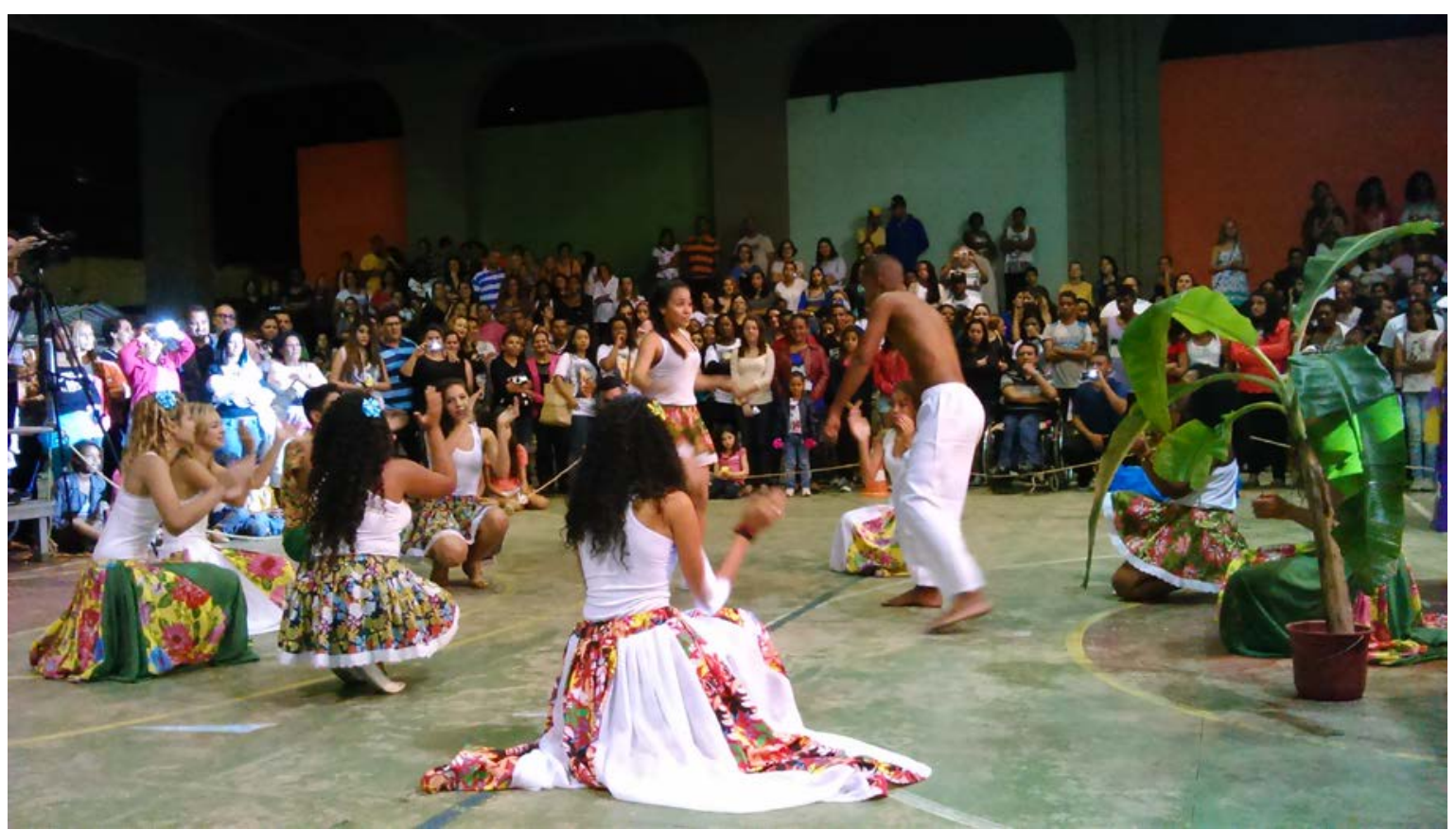

Figura 73 - Dança Folclórica - Piraí - 2014. 


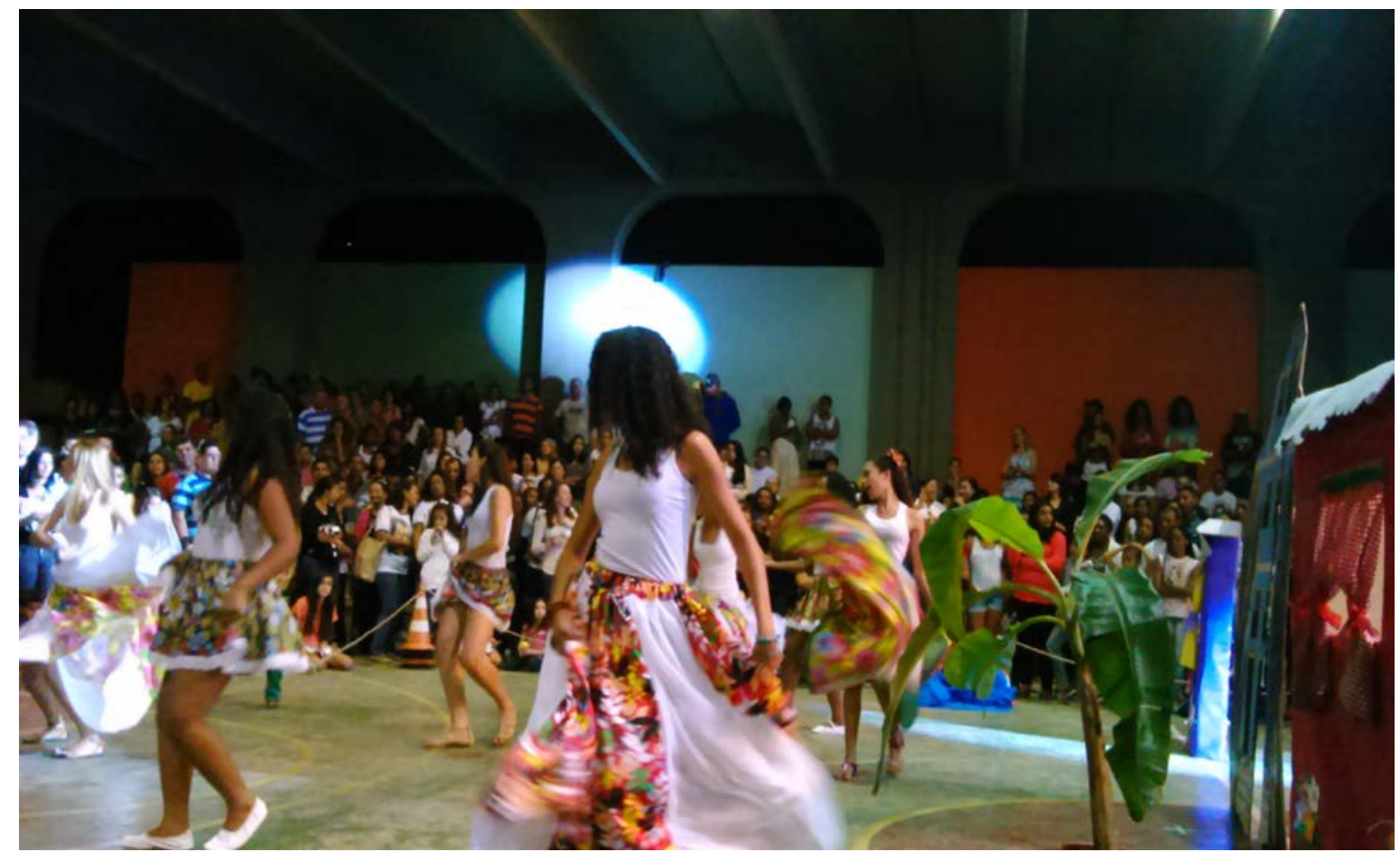

Figura 74 - Dança Folclórica - Piraí - 2014.

U

\section{4}

Saraus e varaus de poesia e chá literário

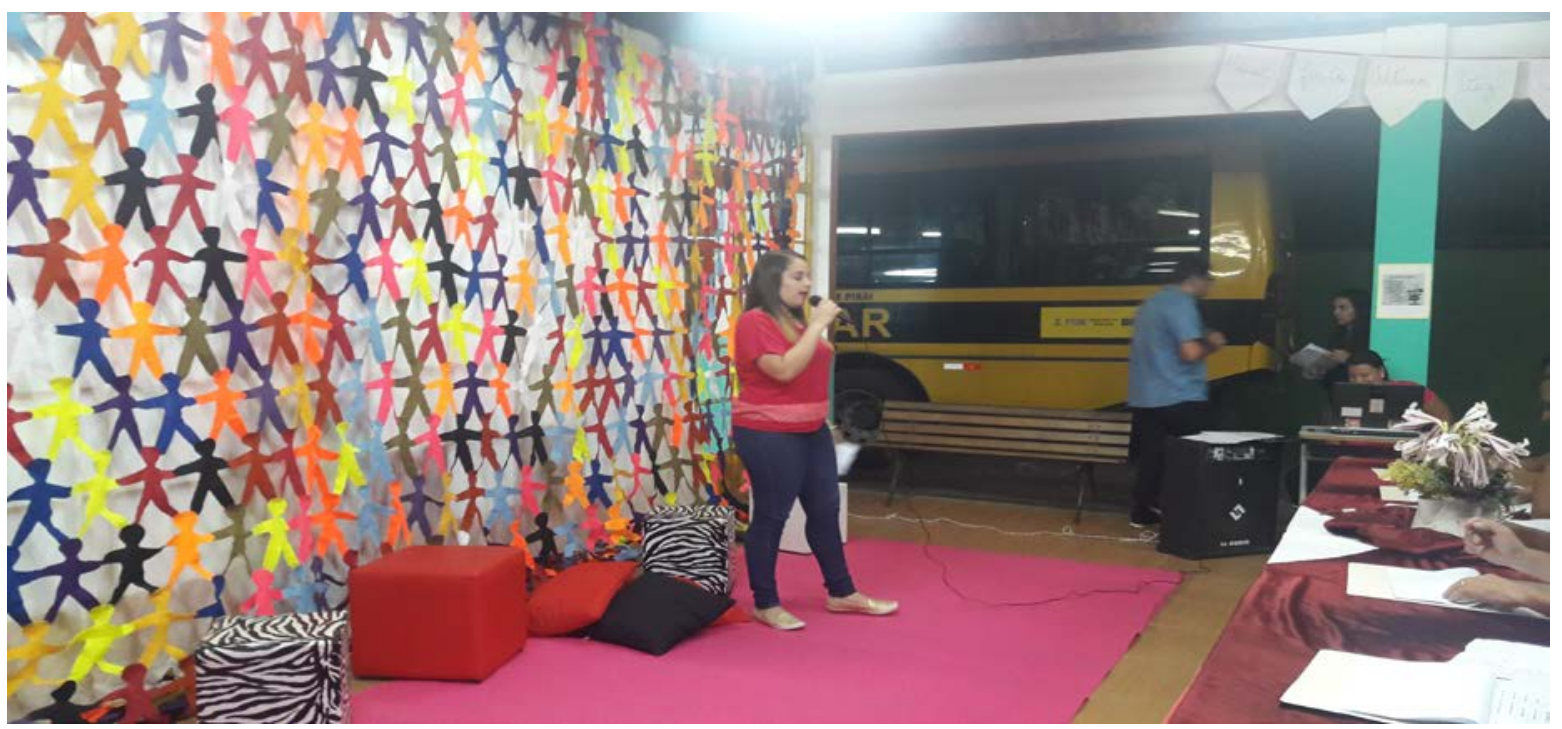

Figura 75 - Declamação de poesia por uma aluna do Ensino Médio C. M. Doutor Aurelino G. Barbosa - 2017. 


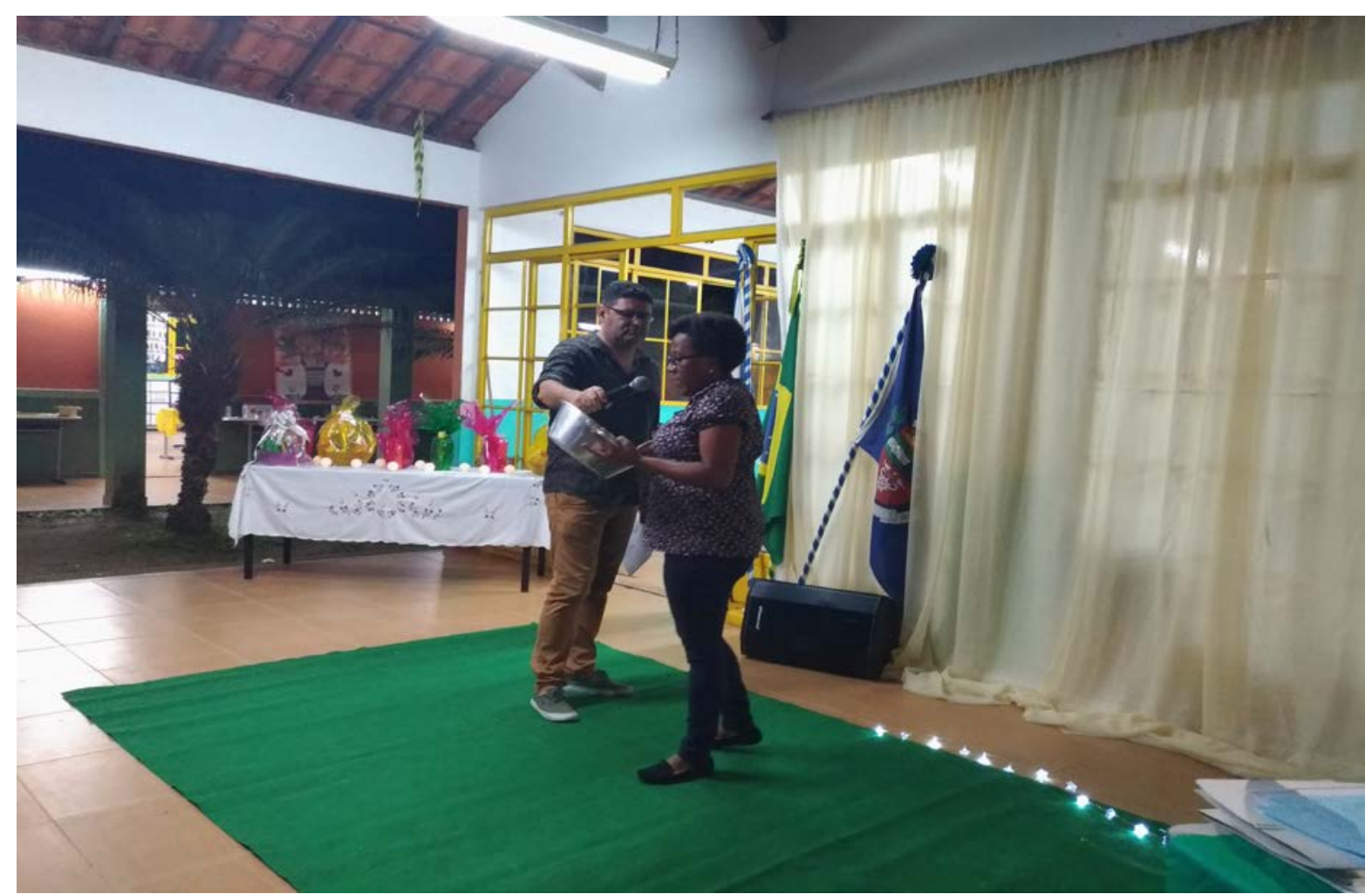

Figura 76 - Declamação de poesia por uma aluna do Ensino Médio C. M. Doutor Aurelino G. Barbosa - 2018.

Lajolo (1994, p. 41-42) ao citar as poesias que acontecem na escola, primeiro ela nos reporta as poesias infantis de Olavo Bilac, e alude a precariedade dos textos poéticos de que dispunha a infância de seu tempo e a baixa qualidade dos versos infantis, apontando também o anacronismo estético da poesia destinada a infância.

“ não seria novidade nenhuma dizer que é excessivamente escassa a nossa poesia infantil. Todos os professores se queixam disso. E basta percorrer um pouco a nossa paupérrima literatura de crianças para nos convencermos de que, no gênero, o que há é pouco e raramente bom. (...) é preciso dizer desde logo que toda a poesia dos nossos mais recentes livros escolares, bem como o gosto poético da maioria dos professores, inspetores e (...) autores ainda não saiu do Parnasianismo. Têm um atraso de vinte ou trinta anos em relação às correntes de poesia recente e hoje dominantes. (LIMA, ALCEU AMOROSO 'Poesia Infantil' in LAJOLO 1994, p. 42)

Essa citação revela a unanimidade de julgamento de três instâncias da instituição literária: o escritor, o editor e o crítico.

O longo tempo que nos separa da publicação dos versos bilaquianos, o panorama da literatura infantil brasileira sofreu consideráveis alterações, que pareceram não ter sido suficientes para invalidar os desencontros e entreveros que 
marcam o relacionamento literatura e escola e em particular o relacionamento poesia e escola ao tempo dos depoimentos acima transcritos.

Segundo Lajolo (1994, p.43), “os textos que integram os livros escolares ainda hoje são considerados de pobre repertório, por isso serem considerados de baixa qualidade”. Essa opinião não pode ser levada em consideração no C. M. Doutor Aurelino G. Barbosa e na E. M. Panaro Figueira que possuem biblioteca, com livros que chegam anualmente doados pelo Governo Federal para compor o acervo escolar; e promovem assim um crescimento no que engloba o 'Incentivo a leitura’ que é desenvolvido desde a Educação Infantil até os anos finais do Ensino Fundamental e Ensino Médio através de projetos. Ocorre no espaço dessas duas escolas eventos que envolvem a leitura, promovendo junto com os alunos reescrita de poesias, paródias com letras de músicas, escritas de poesias inéditas feitas pelos alunos, concursos de poesias com premiação e interpretação de poesias.

Pode-se afirmar que as relações entre literatura e escola (e, consequentemente, entre leitura e escola) são sutis e complexas e não se resolvem por uma melhor seleção de textos, quaisquer que sejam os critérios dessa seleção e mesmo que essa seleção privilegie critérios estéticos. No que concerne a estética no espaço escolar, sabe-se que a estética aos olhos de um profissional é uma coisa, aos olhos de uma amador é outra coisa.

Para Lajolo (1994, p. 43), a qualidade do texto é imprescindível, mas não é tudo. O importante é que esses alunos mesmo em seu amadorismo fornecem aos eventos um brilhantismo particularmente rico em qualidade e envolvimento. No campo da literatura o que importa é a interação que ocorre entre o leitor e o texto que ele conduz. Nesse sentido, deve leitor e texto participar de uma mesma esfera de cultura, isso inclui o uso da língua, e privilegia os vários usos daquela língua que, no decorrer do tempo constituem a tradição literária da comunidade que podem ser observadas nas fotos apresentadas sobre os eventos que envolvem poesias e suas formas de declamação. 


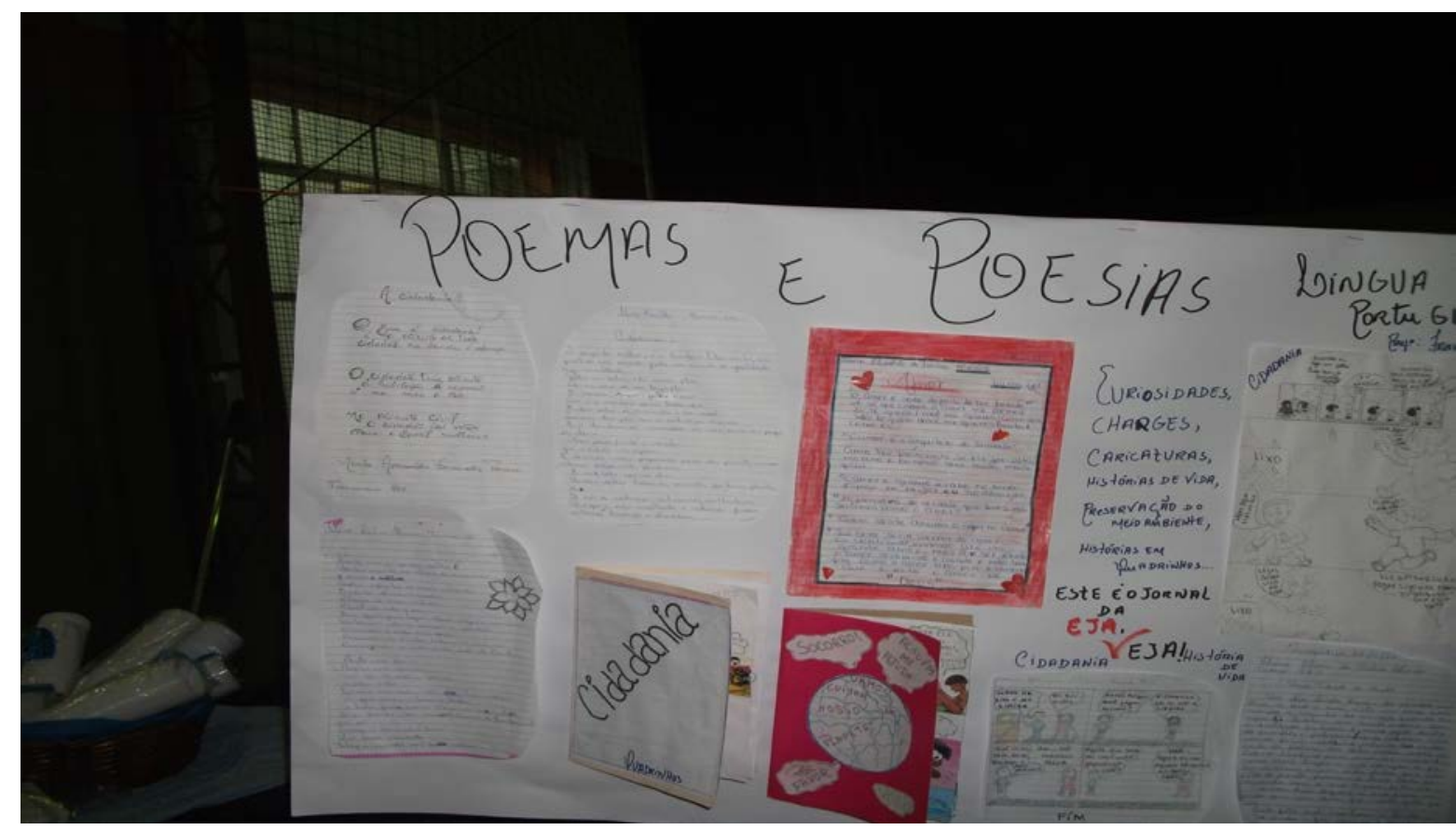

Figura 77 - Trabalho das Turmas da EJA da Escola Municipal Panaro Figueira na Culminância do Projeto sobre Africanidade - 2009.

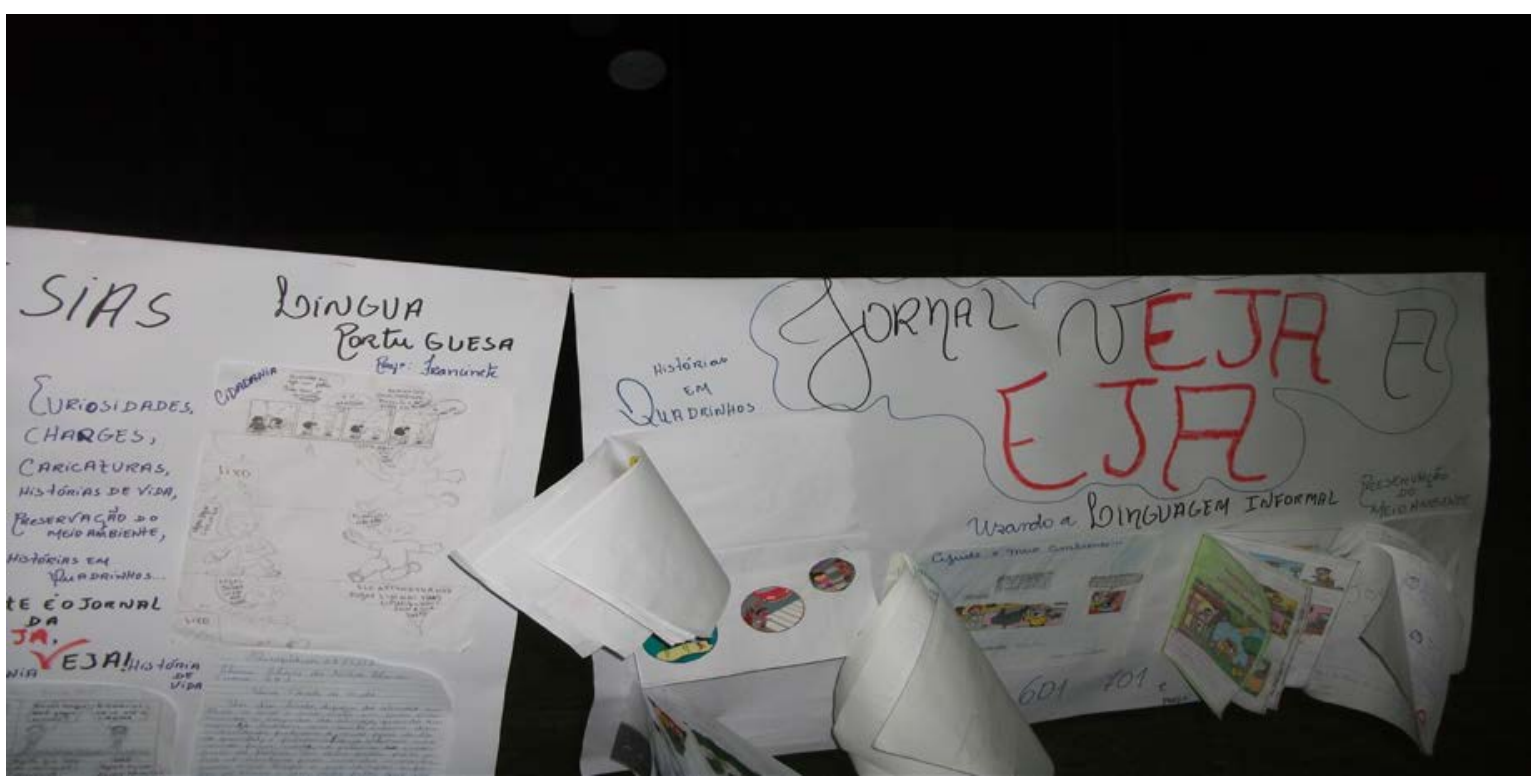

Figura 78 - Trabalho das Turmas da EJA da E. M. Panaro Figueira na Culminância do Projeto sobre Africanidade - 2009.

Lajolo (1994, p. 45) ao citar a retomada que envolve:

"os motivos pelos quais teorias interacionistas contribuem mais significativamente para a discussão do relacionamento entre literatura e escola, pode ser incluído entre as funções da escola, o aumento progressivo e paulatino da familiaridade do aluno com textos que ampliem seus horizontes de expectativas, numa perspectiva de familiaridade crescente com esferas de cultura cada vez mais complexas que incluem, no limite, aqueles textos que, tendo a sanção dos canais competentes, configuram a literatura”. 
Para Lajolo (1994) escola em momento nenhum deve priorizar apenas a inclusão de textos considerados bons e superiores entre os textos escolares, pois esse fato não soluciona nenhuma das faces da crise de leitura. Porque a presença de excelente texto, em um manual pode ficar sem contrapartida, pois um texto tido como bom pode ser diluído pela perspectiva de familiaridade crescente com esferas de cultura cada vez mais complexas que incluem, no limite, aqueles textos que, tendo a sanção dos canais competentes, configuram a literatura. Pude observar esse fato aqui mesmo na PUC-Rio. Os materiais que circulam entre nós, alunos da universidade deveria ser de fácil acesso para as escolas públicas em geral, pois o governo custeia as pesquisas em nível de universidade, mas essas pesquisas pelo que vejo ficam nos acervos das próprias universidades. Poucos têm acesso a esses excelentes materiais de leitura. Há uma necessidade proeminente de que haja uma ponte linear entre Educação Básica e Universidades, pois assim o paradigma de distanciamento entre a continuidade dos estudos seria quebrada entre esses dois níveis de ensino. Deveria haver uma abertura maior entre os escritores e poetas que saem das universidades, esses deveriam usar o chão da escola para divulgação de seus trabalhos, mas não é isso que ocorre.

As escolas têm autores parceiros, mas são autores, poetas e escritores anônimos, que buscam através do chão da escola a divulgação de seus trabalhos. A academia deveria fazer parte da vida das comunidades escolares de baixa renda e de difícil acesso, mas não é assim que acontece. Os entraves, a não disseminação dos materiais que estão dentro das universidades, cada dia se distanciam mais do povo de forma geral. Principalmente agora com essas mudanças políticas sem precedentes.

Mesmo assim, é no chão da escola que ocorre os maiores eventos ligados a promoção de leitura. Grande parte desses eventos culmina em “chá literário”, que é uma forma de fazer com que todos do espaço escolar interajam entre si. Por isso serem chamados de 'culminância'. 


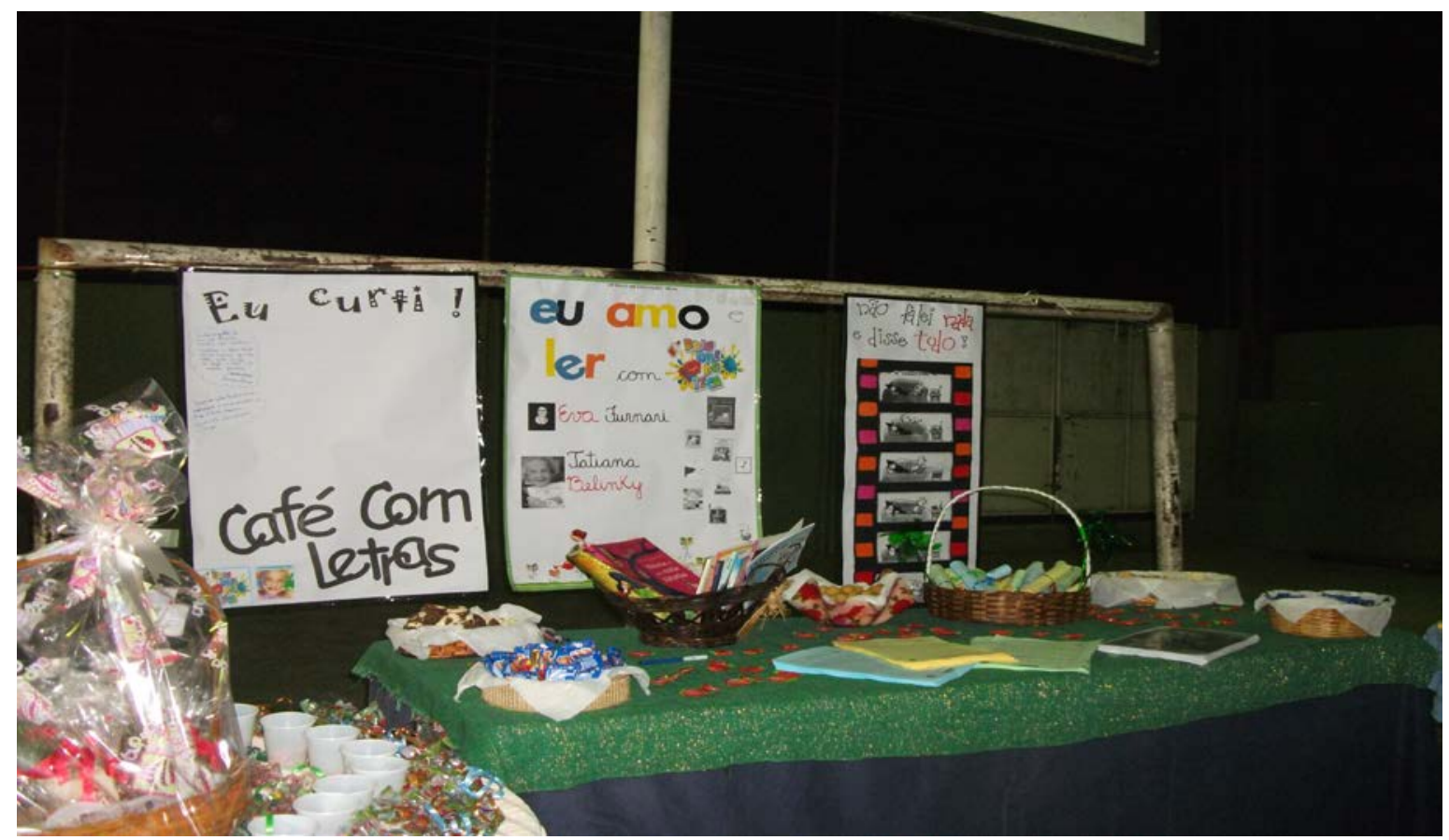

Figura 79 - Mesa de variedades para o chá literário.

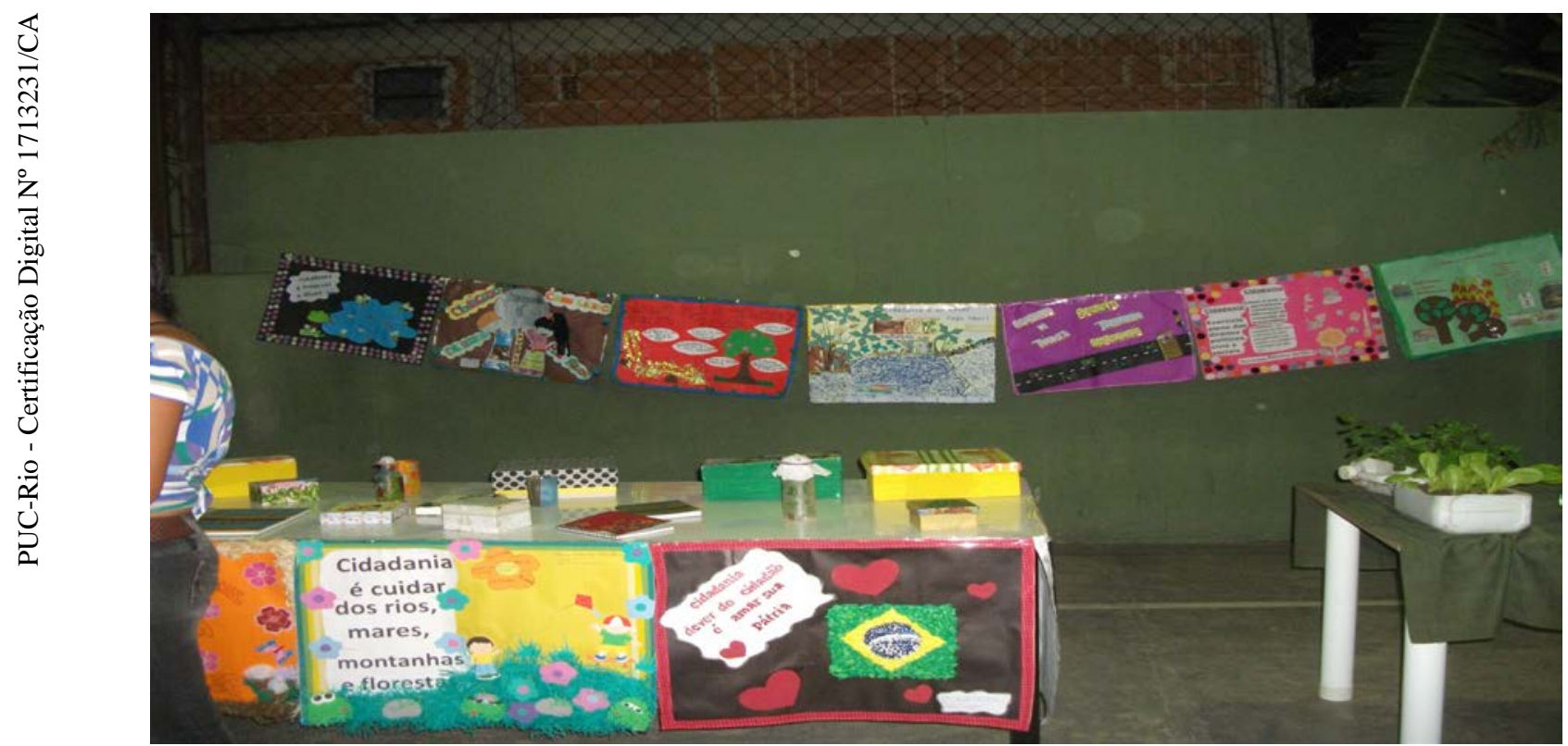

Figura 80 - As aulas de Ciências em movimento pela Preservação Ambiental. 


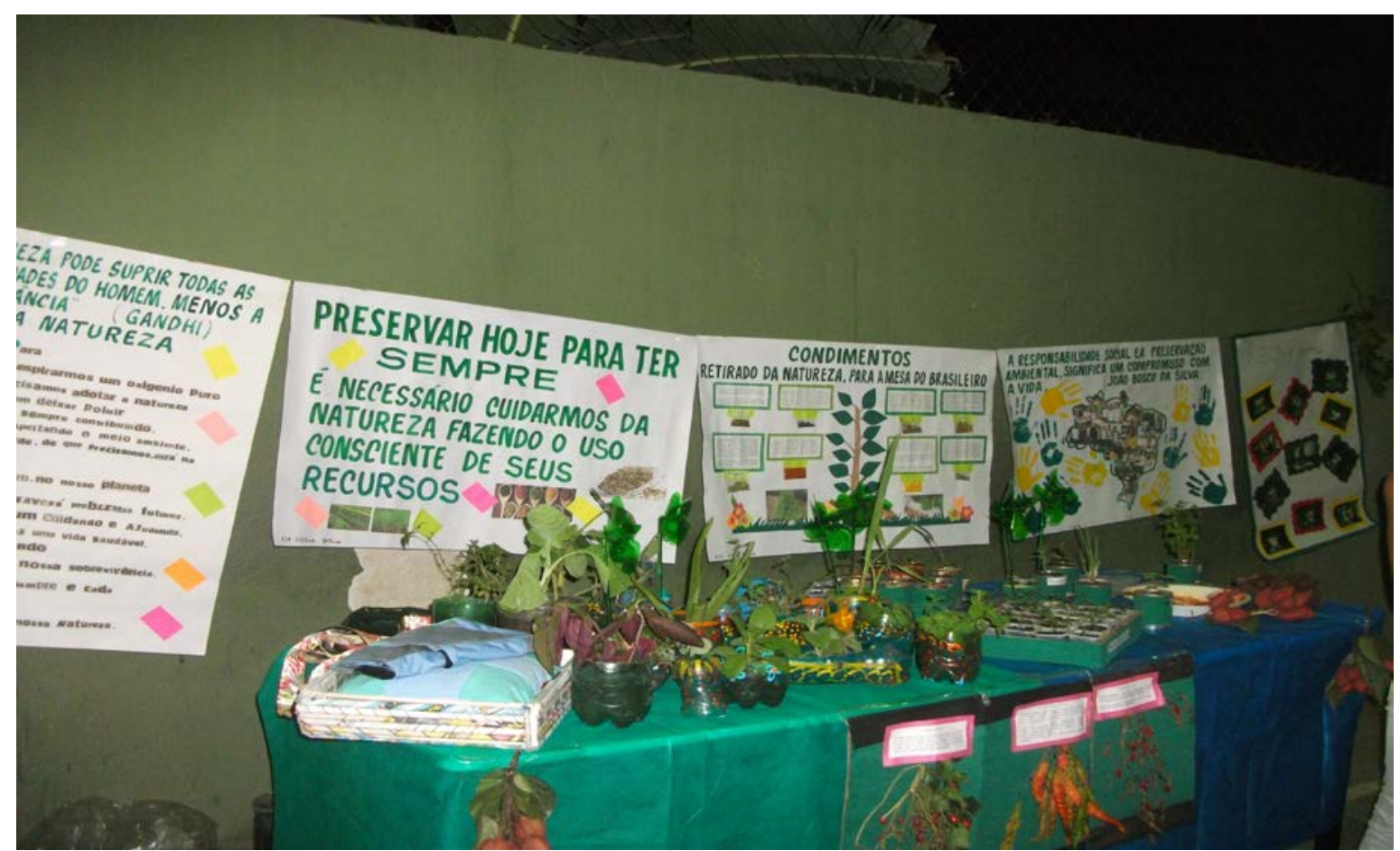

Figura 81 - Plantas medicinais colhidas e levadas pelos alunos da EJA.

\section{5}

Fotos e imagens de danças performáticas, gincanas e artes visuais desenvolvidos pelos alunos

Como já se pode obsevar, a Educação atualmente no mundo e no Brasil oferece muitos caminhos para o desenvolvimento da aprendizagem através das Artes. Dessa forma, o desenho, a pintura e as imagens passam a fazer parte do cotidiano escolar como uma forma de aquisição e difusão de conhecimentos tanto para crianças, jovens e adultos. Crianças aprendem e desenvolvem melhor suas habilidades criativas através dos desenhos, das pinturas e das imagens principalmente na Educação Infantil e no Ensino Fundamental nos anos iniciais, apesar de que a escola Dr. Aurelino G. Barbosa e a Escola M. Panaro Figueira, investem através de seus professores, numa aprendizagem construtivista, que parte da criação pelos estudantes, de painéis coletivos e individuais, poesias escritas sem o uso de nenhum aparato tecnológico, trabalhos diversificados de pinturas desenvolvidos nas aulas de Artes, trabalhos manuais confeccionados por eles, e outros... 


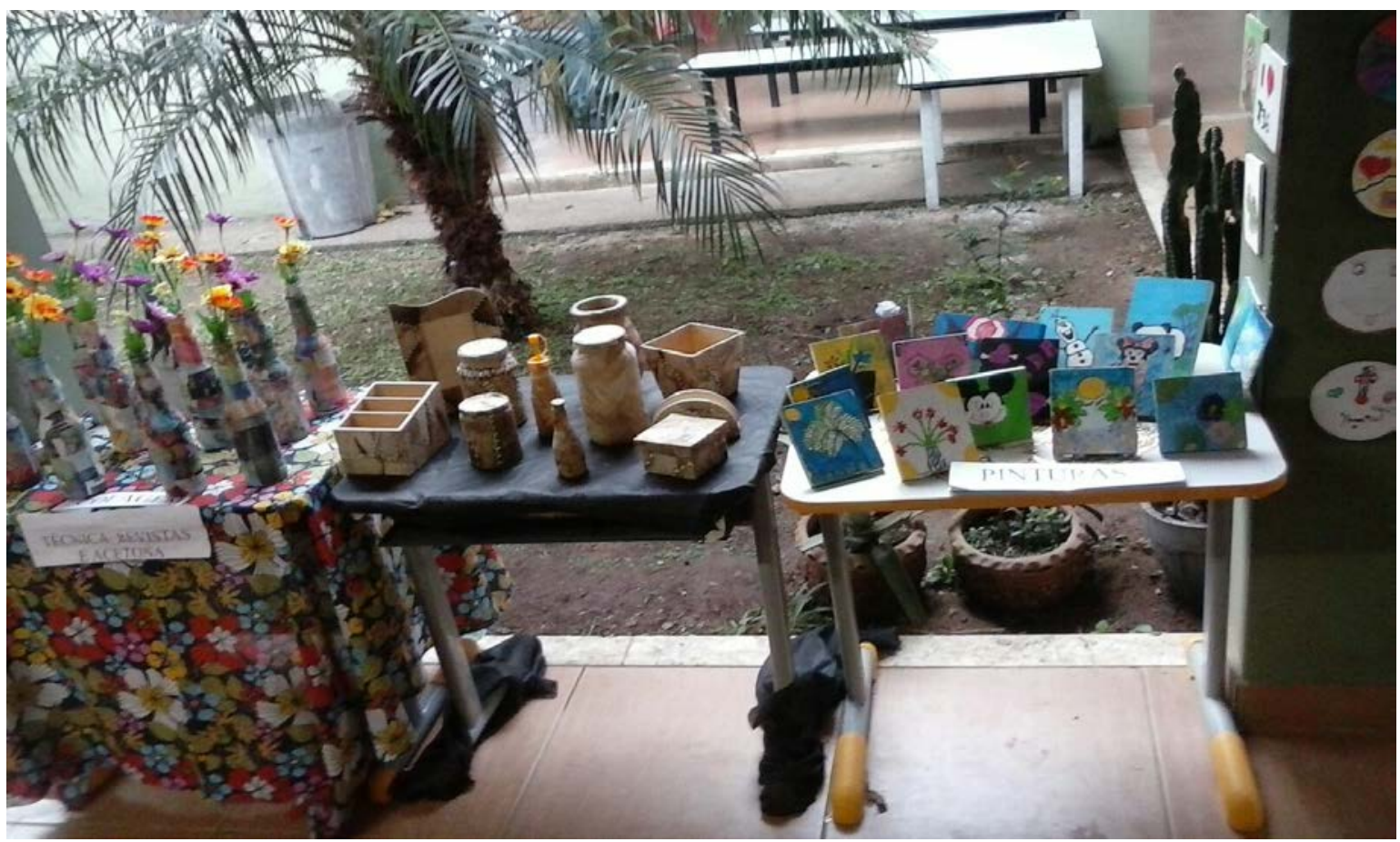

Figura 82 - Trabalhos artísticos desenvolvidos pelos alunos com o auxílio da professora de Artes Celly Flávia.

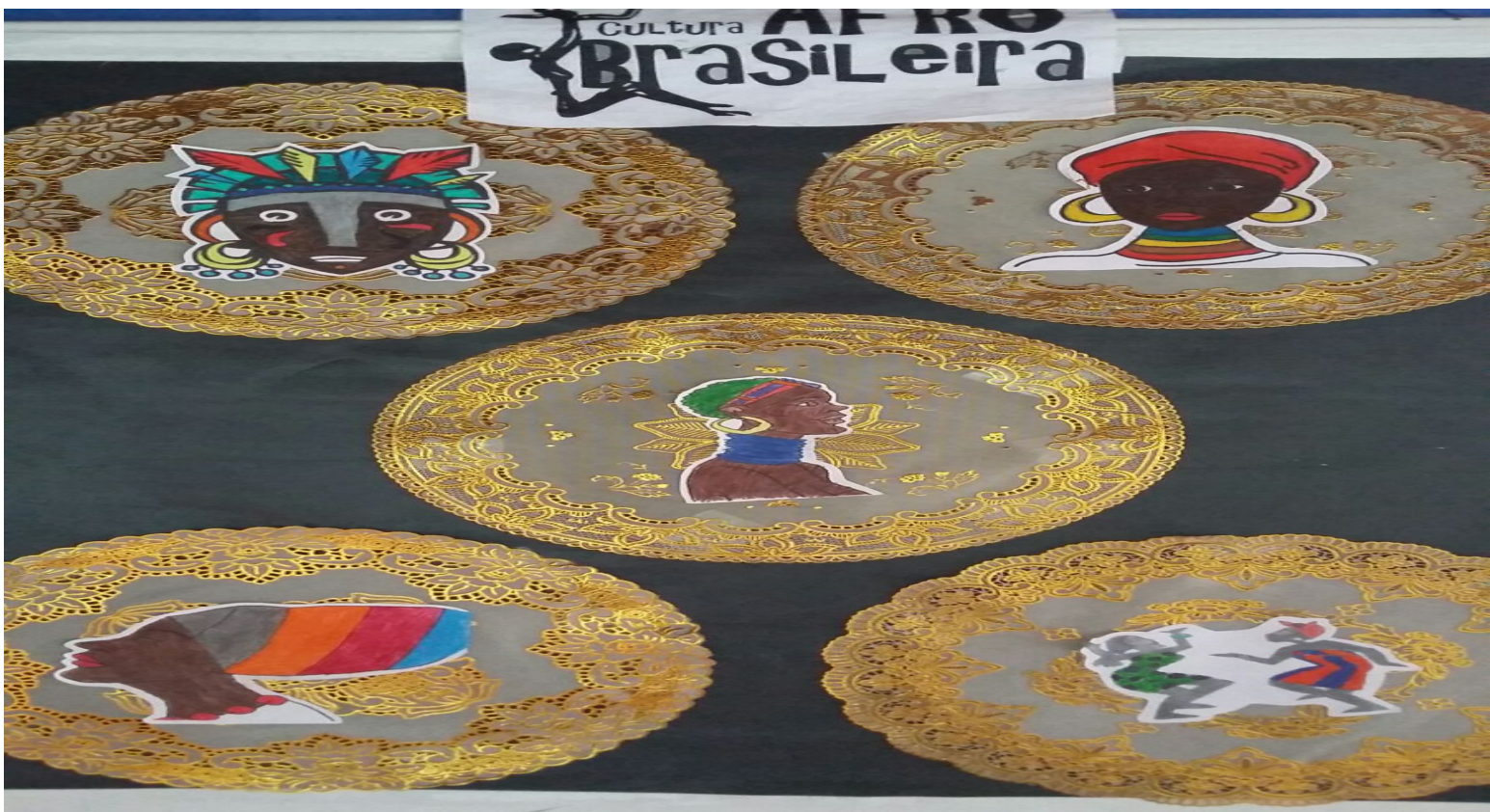

Figura 83 - Trabalhos artísticos desenvolvidos pelos alunos com o auxílio da professora de Artes Celly Flávia. 


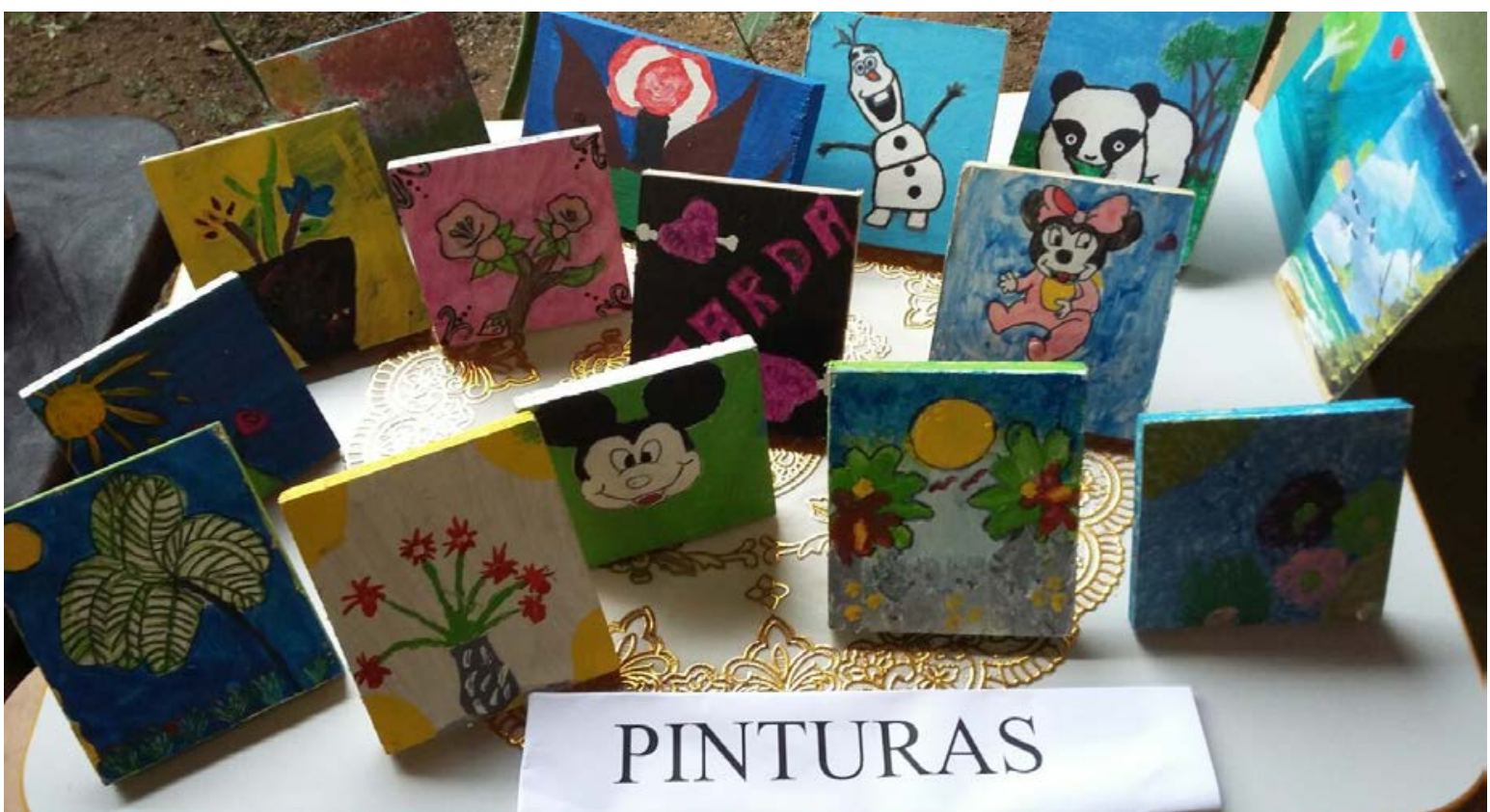

Figura 84 - Trabalhos artísticos desenvolvidos pelos alunos com o auxílio da professora de Artes Celly Flávia.

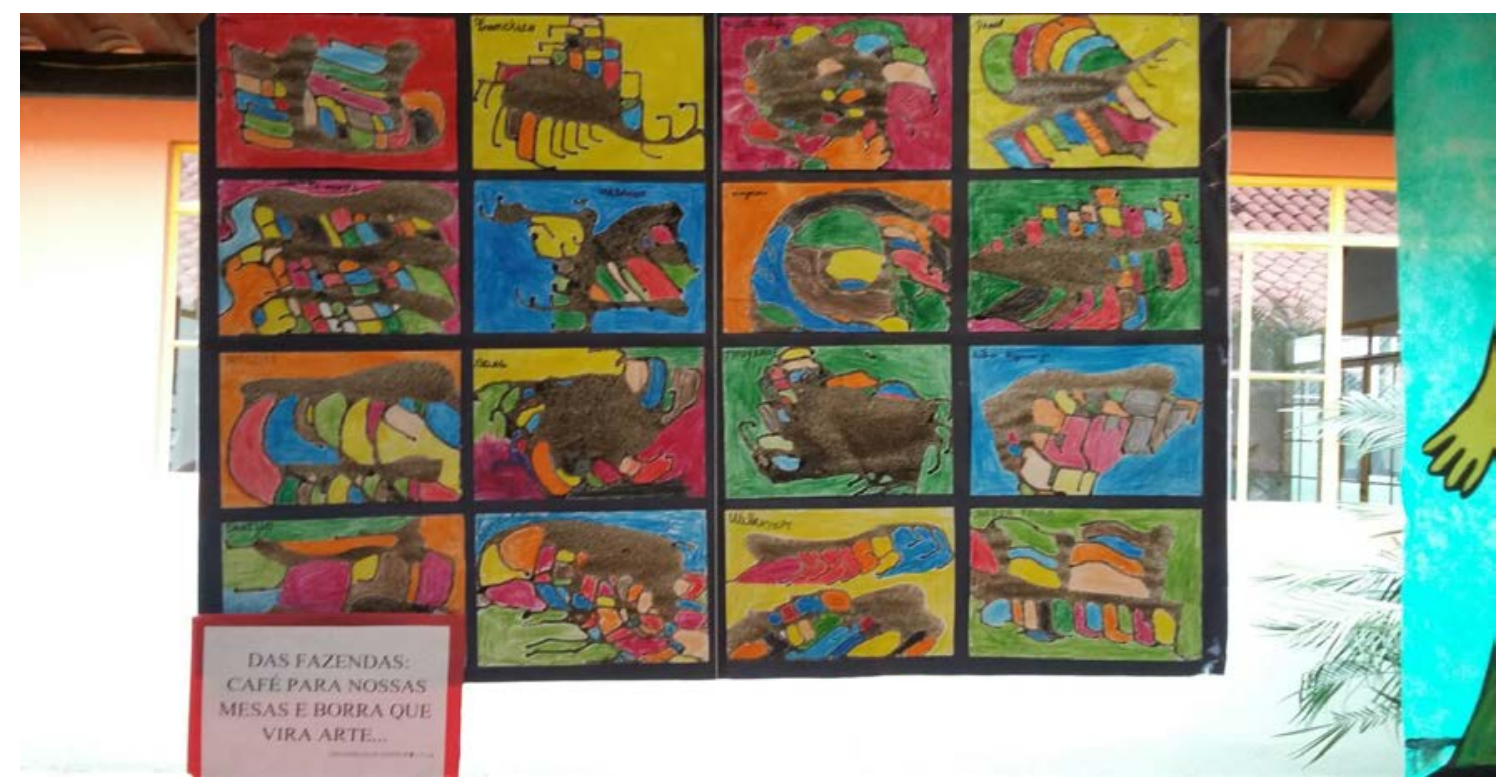

Figura 85 - Trabalhos artísticos desenvolvidos pelos alunos com o auxílio da professora de Artes Celly Flávia. 


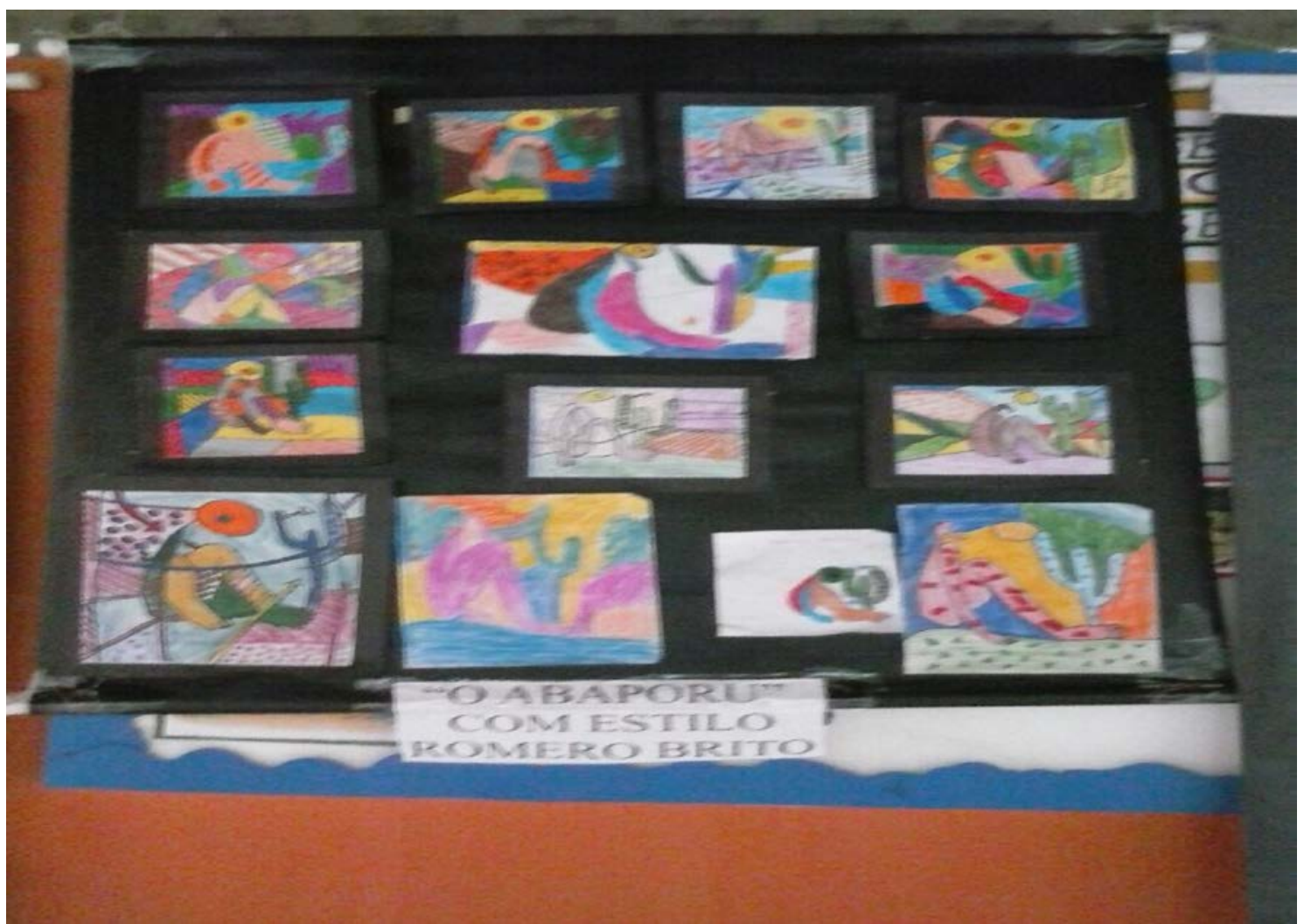

Figura 86 - Trabalhos artísticos desenvolvidos pelos alunos com o auxílio da professora de Artes Celly Flávia.

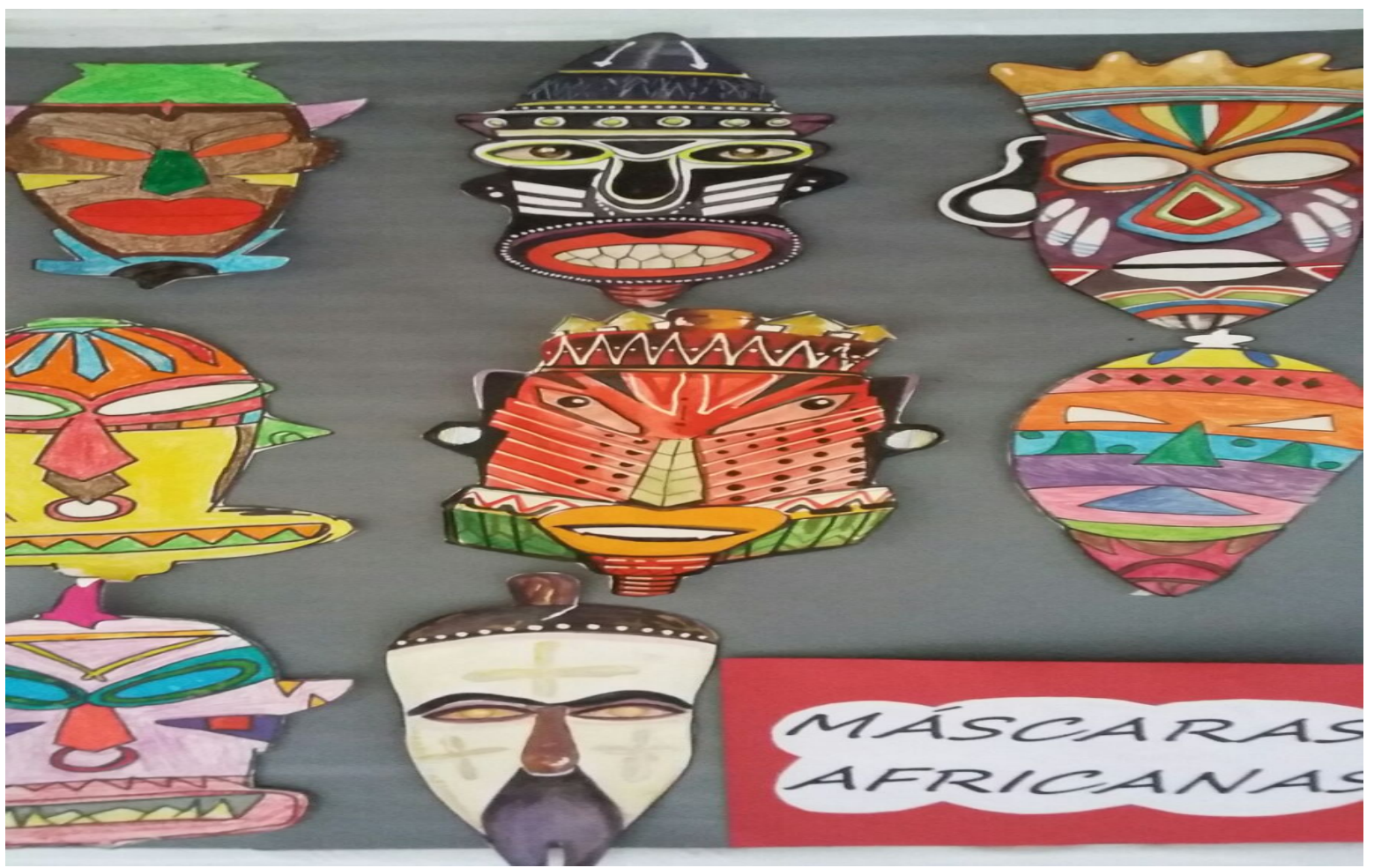

Figura 87 - Trabalhos artísticos desenvolvidos pelos alunos com o auxílio da professora de Artes Celly Flávia. 


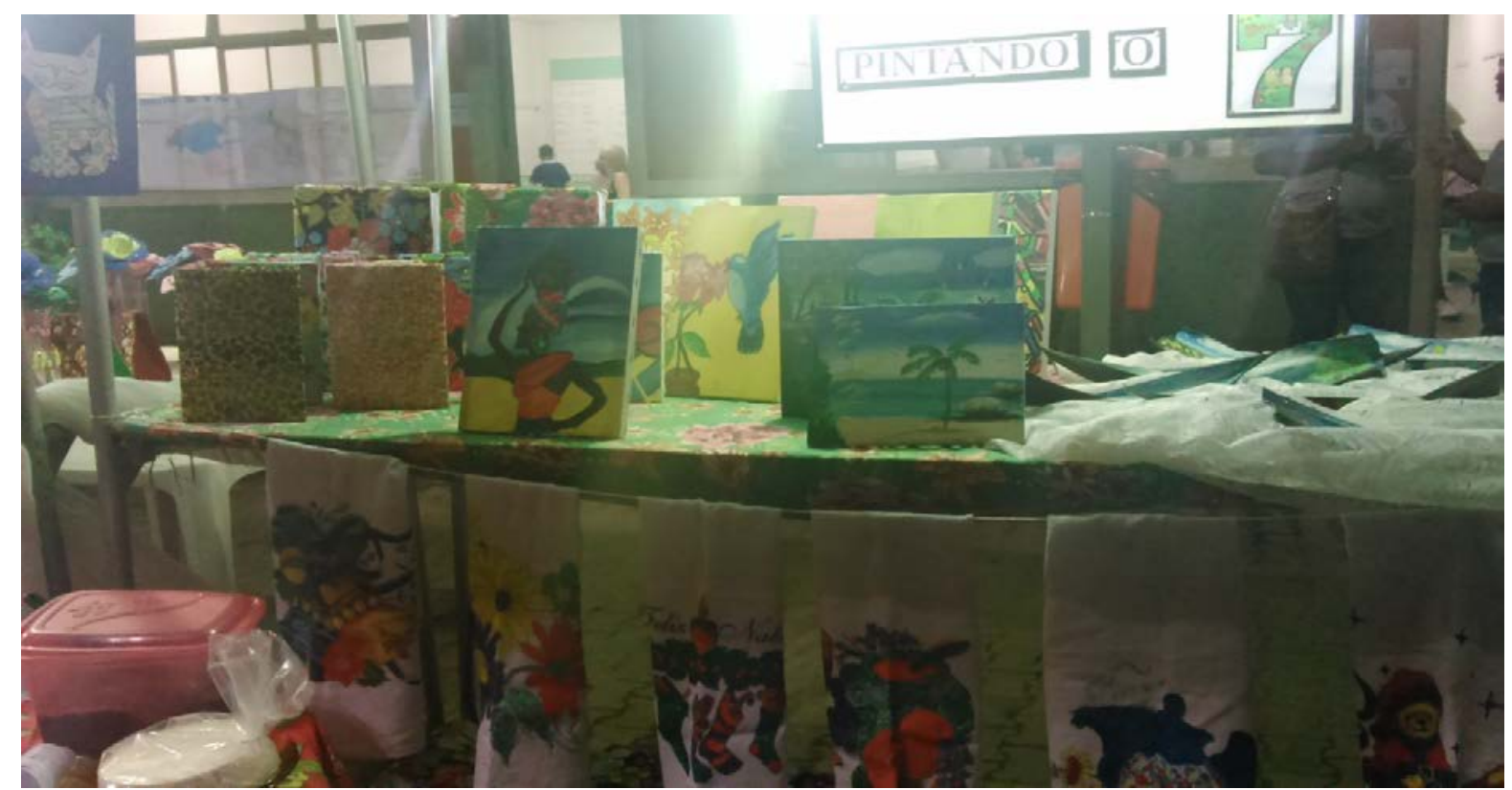

Figura 88 - Barraca montada no Festeja em Piraí.

O que se percebeu com o desenvolvimento desses trabalhos, é que os alunos precisam de alguém que estimule sua imaginação, e que lhe mostre o que é real e o que é imaginário, dentro do seu cotidiano de vida. As Artes sempre foi uma forma de aprendizagem capaz de desenvolver habilidades do indivíduo, por isso devemos utilizá-la como um dos caminhos para o conhecimento, no caso das fotos e imagens mostradas acima, ocorreu uma parceria interdisciplinar que permitiu que esses trabalhos fossem desenvolvidos e apresentados em feiras culturais e eventos promovidos pela escola e pela Secretaria de Educação, uma parceria que permitiu a criação de trabalhos performáticos, pinturas e desenhos, desenvolvidos entre as disciplinas de Artes e Educação Física, com o apoio dos professores de outras áreas do conhecimento. 


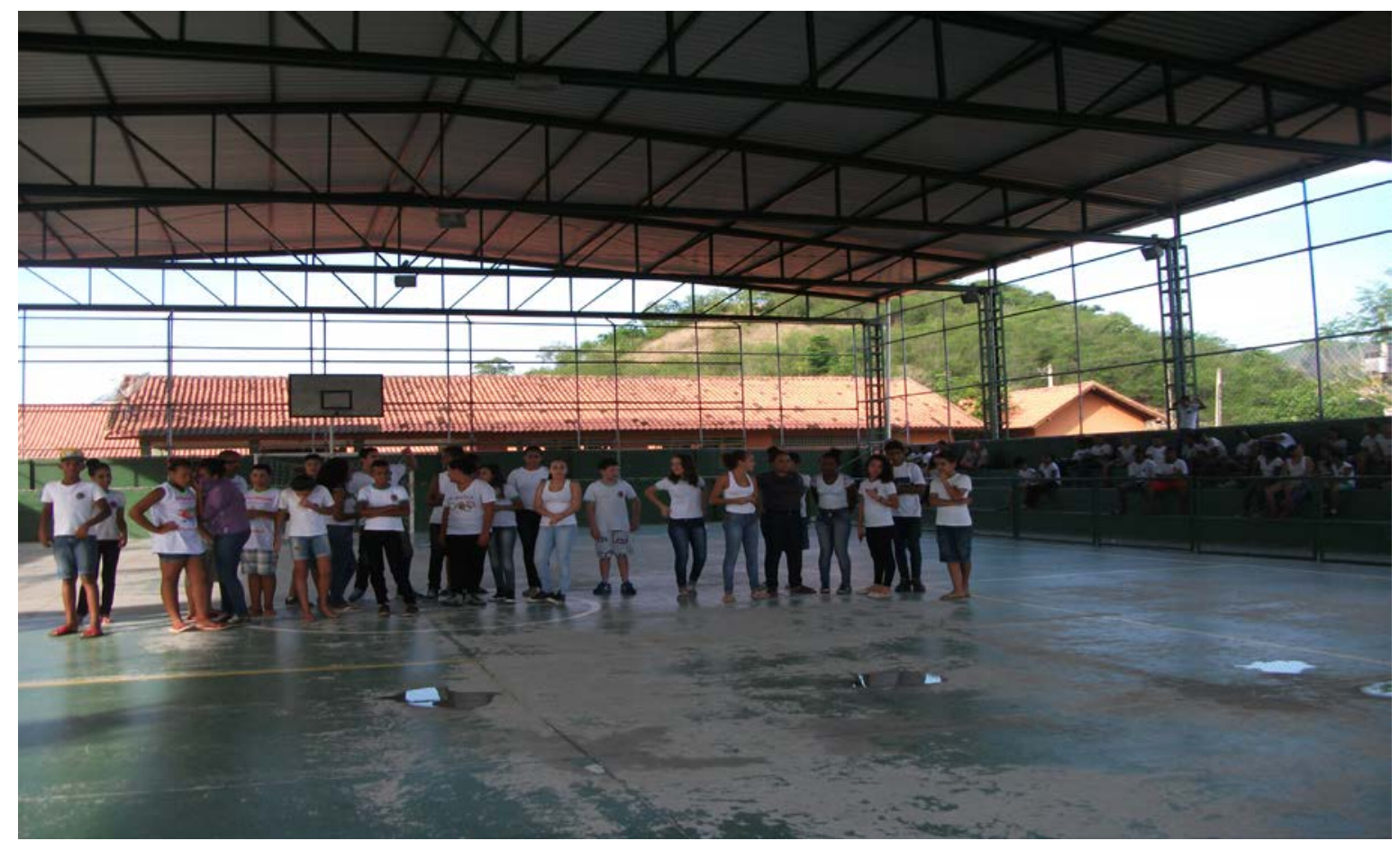

Figura 89 - Gincana desenvolvida com o Ensino Fundamental $6^{\circ}$ ao $9^{\circ}$ ano sob a orientação da professora de Educação Física Célia Polati - ano 2013.

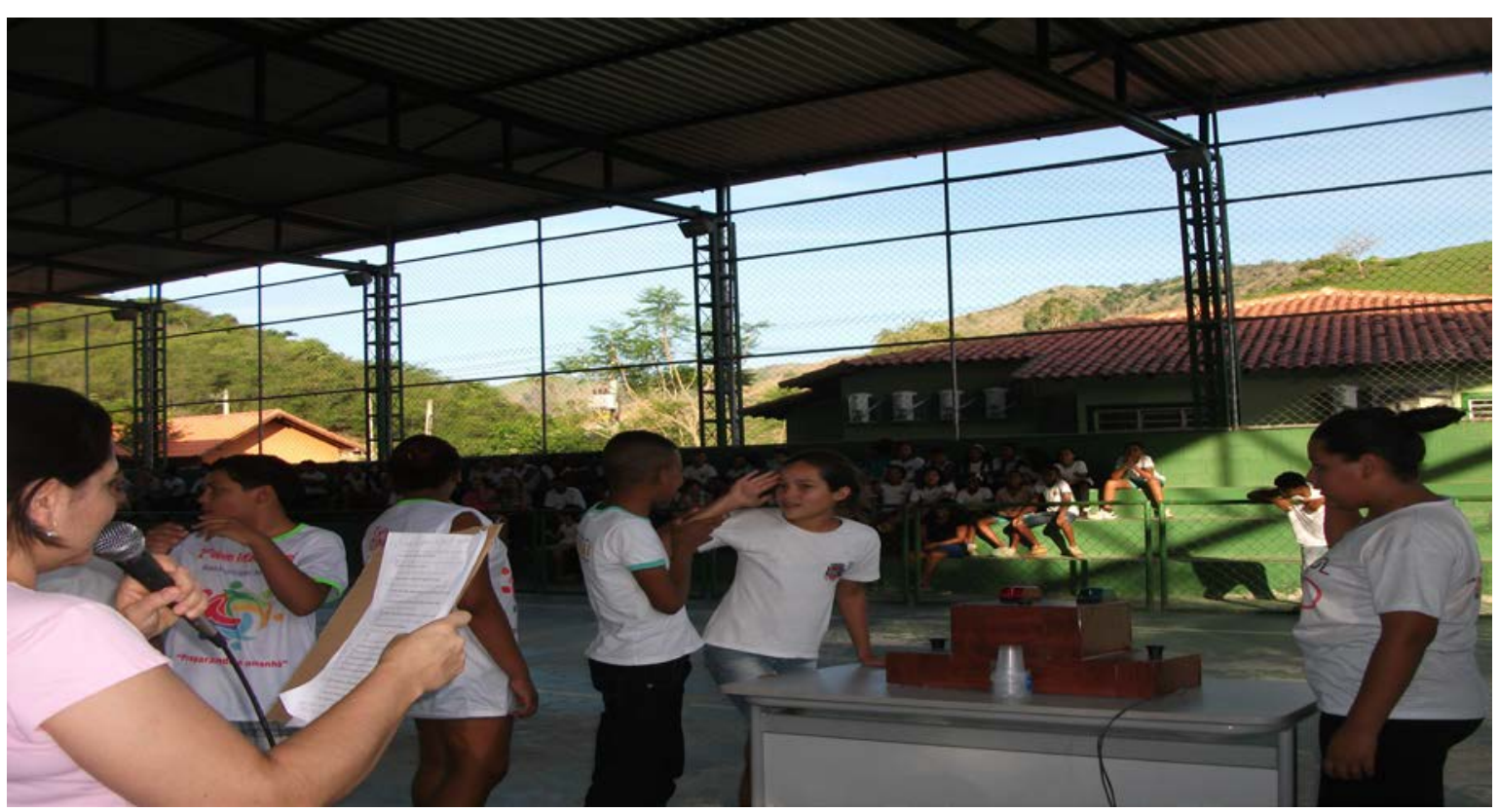

Figura 90 - Brincadeira passa ou repassa participação das turmas Ensino Fundamental; Ensino Médio e EJA. 


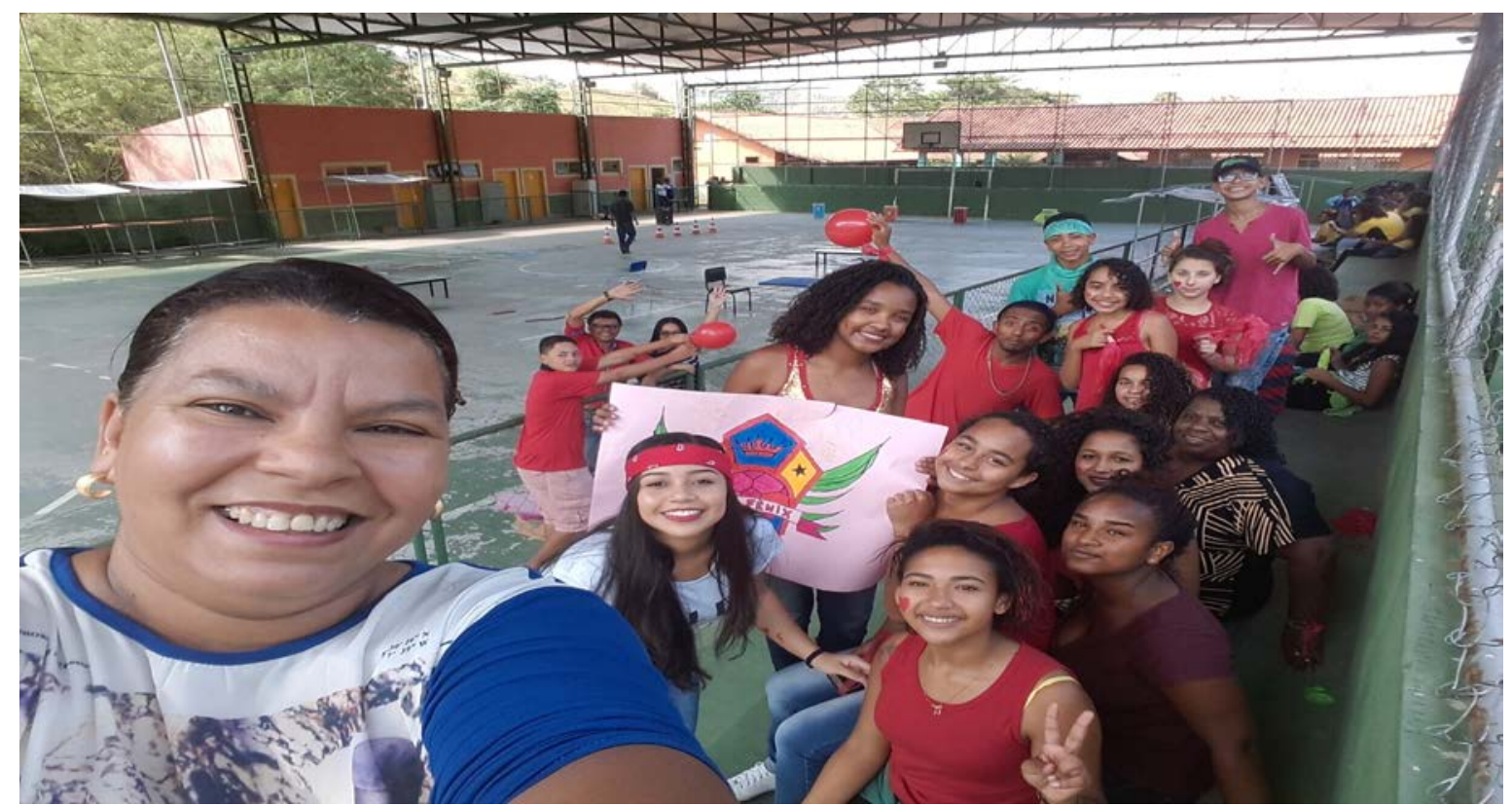

Figura 91 - Gincana interdisciplinar - time vermelho - 2016.

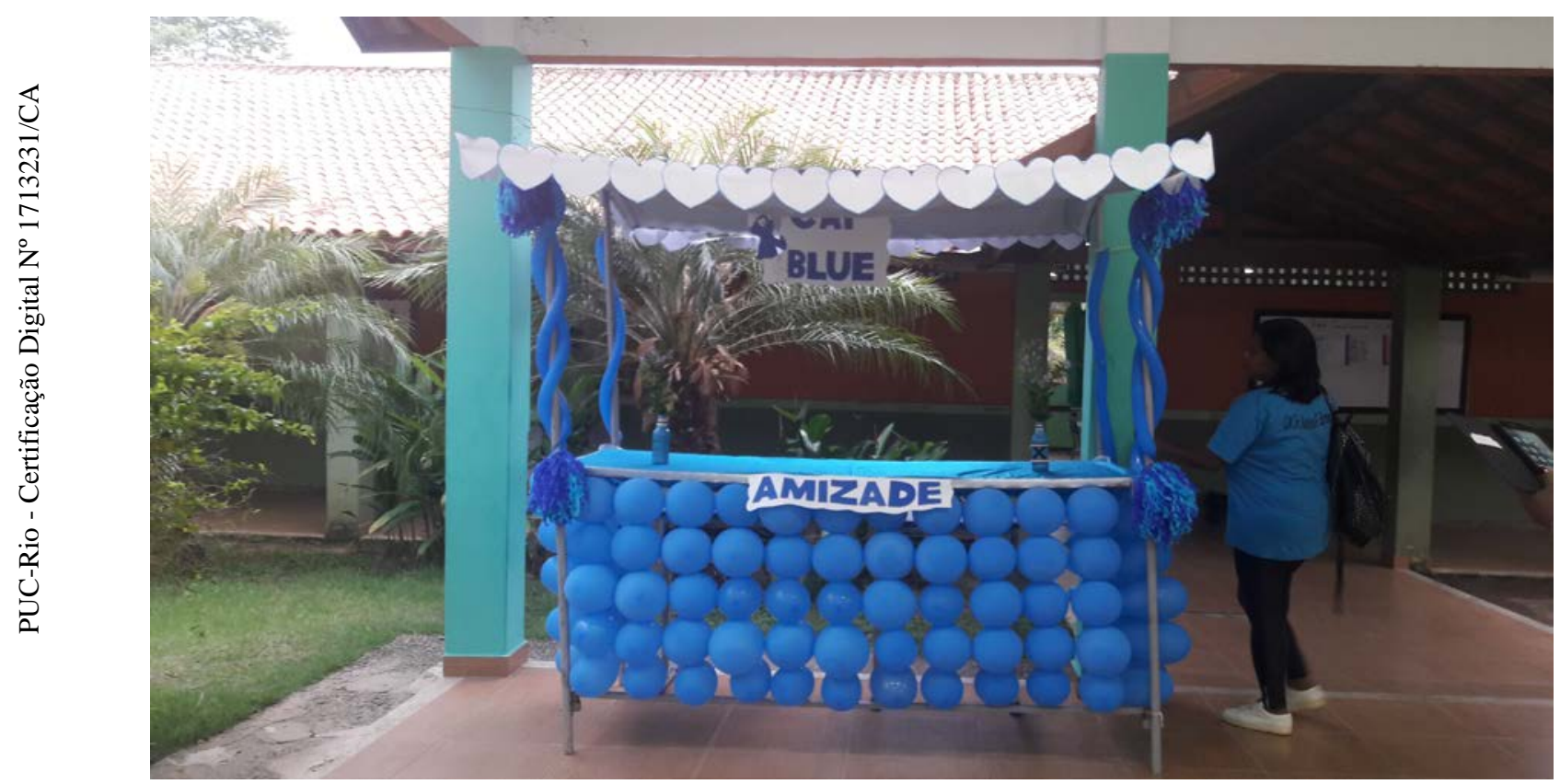

Figura 92 - Gincana Consolidando Amizades. Trabalho desenvolvido na Gincana Interdisciplinar do C. M. Doutor Aurelino G. Barbosa 2017. 


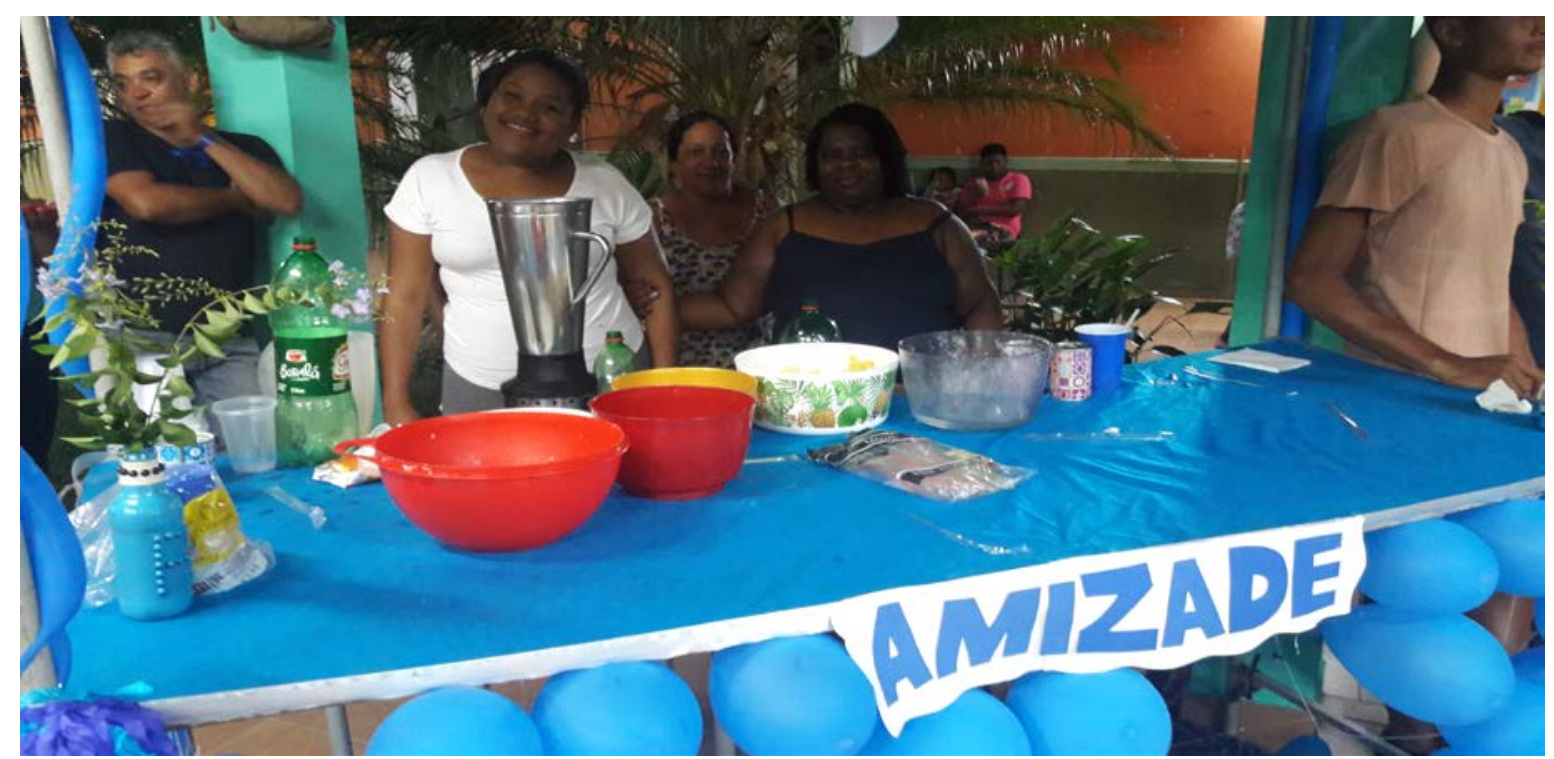

Figura 93 - professora Francinete e alunos do Ensino Médio e da EJA - Educação de Jovens e Adultos - 2017.

A interdisciplinaridade deve ser sempre o viés da escola, pois trabalhos desenvolvidos dessa forma encontram sempre uma resposta positiva no que tange a uma educação de qualidade. O município de Seropédica ainda possui alguns entraves políticos que a faz se manter a margem de uma educação de qualidade, diferente das escolas do município de Piraí onde ocorre um investimento maciço em educação, que hoje permite a esse município ser um dos mais desenvolvidos em matéria de saúde e educação. 


\section{Leituras escrita e oral}

\section{1}

\section{O Contador de Histórias}

Além de enriquecer o currículo escolar, a diversificação de eventos cria oportunidades para que os alunos desenvolvam de forma prazerosa leituras em voz alta para outras turmas. Muitas vezes, de forma flexível, sugerimos aos alunos que escolham um livro de que gostam, ou um filme com o qual se identifiquem, e a partir daí criem resenhas ou façam resumos para serem lidos oralmente, uns para os outros. Procura-se, assim, incentivar indiretamente a leitura e a narrativa oral. Neste contexto, a figura do contador de histórias, mediador que se caracteriza para dar vida às narrativas que traz para o grupo de alunos, tem um papel fundamental.

Uma das atividades desenvolvidas é a interpretação de peças teatrais que tem como personagens os próprios alunos representando. Envolvendo-os em sua própria criatividade inventiva, ao representar e contar as suas histórias através da ludicidade, esta atividade implica uma releitura memorialística de imagens e fotos, dando vida nova a contos e narrativas perpetuadas pela literatura popular. A observação da representação do outro também funciona como incentivo a leitura. A intenção deste trabalho é a de promover uma proposta pedagógica, que leve o ouvinte/espectador de histórias a achar prazeroso o mundo da leitura de histórias em livros, sejam estes infantis ou não.

A aprendizagem intencionada aqui pode ser realizada através da ludicidade, ou estimulada com a ampliação do imaginário do aluno pelo contato imagens. Neste caso, ao terem liberdade para se expressar, eles ampliam seus instrumentos de leitura de mundo. Enquanto condutor dessa aprendizagem, o professor se coloca à disposição para que haja a efetivação desse processo. Muitas vezes, os professores envolvidos nesse trabalho interdisciplinar utilizam suas próprias experiências, contando fatos e histórias que tenham vivido. Ao incluir vivências pessoas no ensino da língua através da leitura narrativa de contos e 
fábulas, que permeiam os livros didáticos das escolas, dinamizam o mundo do texto, aproximando-o do mundo das experiências e trocas orais.

Faz-se também a apresentação, nesse contexto, de vídeos com filmes diversificados e documentários de lugares com base em fotos e imagens ilustrativas. Busca-se, assim, atrair o interesse dos alunos, para uma nova forma de leitura e interpretação textual, aguçando a sua curiosidade com relação aos fatos apresentados, despertando a ludicidade como meio de aprendizagem. Renovando, assim, os parâmetros educacionais, estimula-se o desenvolvimento, nos alunos, de aptidões e instrumentos para a leitura através do mundo visual e oral.

O professor que se caracteriza, e se apresenta a eles como um personagem de contos e narrativas, faz com que esses alunos vivenciem a história de forma interacional... O professor se torna o condutor de uma aprendizagem para a vida. O aluno perde a sua timidez, e passa a ser o ator representativo das histórias montadas e contadas através de representação musical, teatral ou mesmo pessoal...

Ao escolher um livro ilustrado, os alunos são estimulados a aprender através de uma leitura visual das imagens, desenvolvendo assim a oralidade com histórias criadas por eles mesmos através de sua imaginação, causando interesse e estímulo naqueles que lhes ouvem. Assim, todo um processo de leitura, e seu entendimento, acontece a partir de imagens. Atualmente, mesmo as escolas tradicionais já quebraram o paradigma em busca de novos caminhos para uma educação construída através das artes, seja ela qual for. 


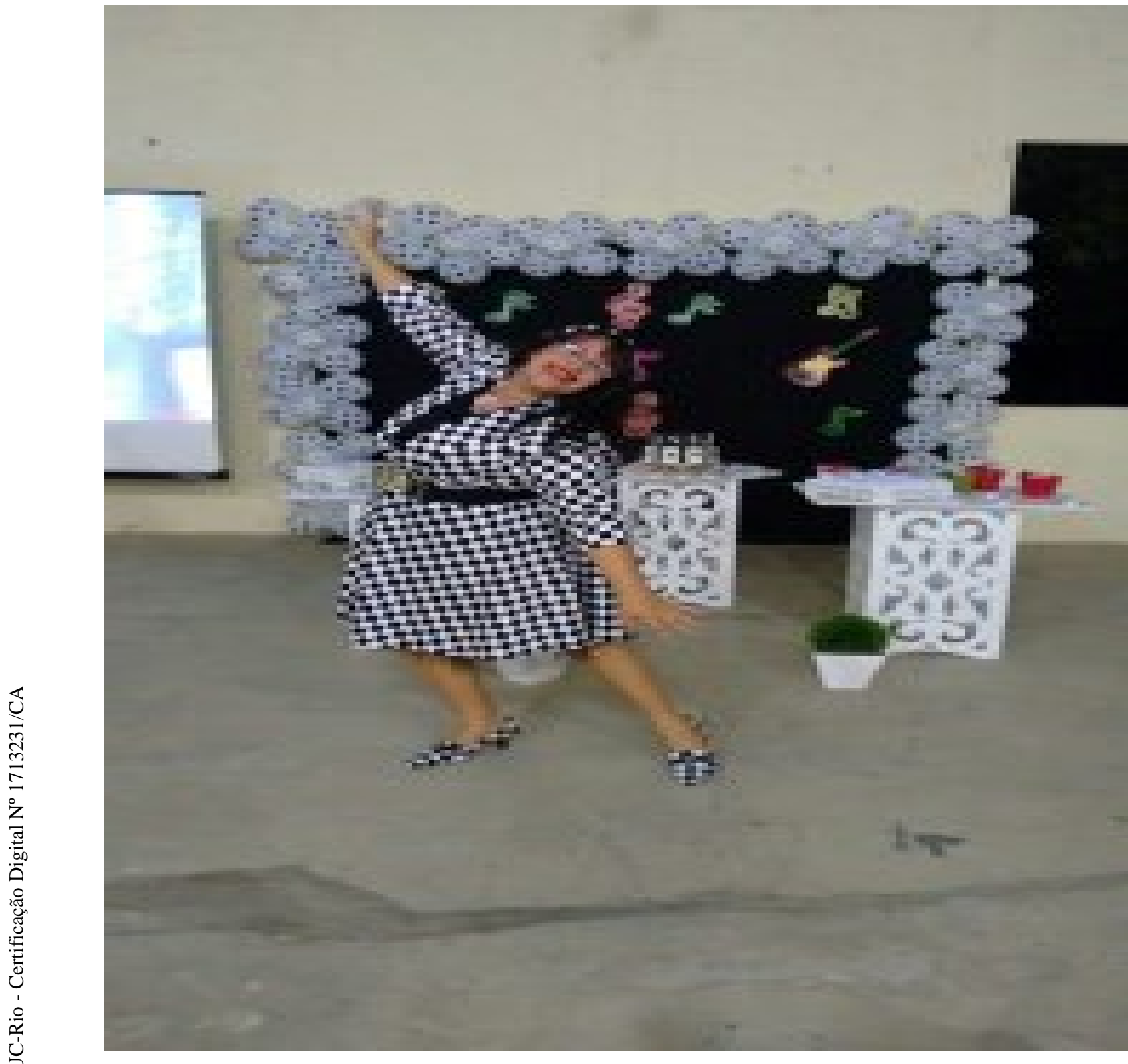

Figura 94 - Professora Rosemar Pereira da Silva em uma de suas vestimentas.

Sobre a figura do contador de histórias, Benjamin (2018, p.20) nos diz: “A distância a que ele se reporta são pontos de vista impostos por uma experiência que ocorre quase diariamente. A distância apresentada por ele diz que a arte de contar histórias está próxima de seu fim”...

Na periferia das grandes cidades e na zona rural, entretanto, ela permanece viva. Nesses locais, ainda há pessoas que se propõe a contar histórias que foram contadas a eles pelos seus antepassados, histórias que muitas das vezes os alunos reproduzem em suas escritas, quando pedimos que escrevam contos... Esses 
contos às vezes correspondem a histórias trágicas de suas próprias vidas, de seus parentes, de seus vizinhos, de suas Famílias, de sua cidade, de sua comunidade...

A professora Rosemar Pereira da Silva (na foto acima) do C. M. Doutor Aurelino G. Barbosa é uma eterna contadora de histórias. Ela se adéqua sempre ao momento em que se precisa, e se torna oficialmente a pessoa que ajuda os alunos a se libertarem de suas amarras, e se tornarem verdadeiros personagens nesse momento único que são as manhãs e as tardes em que ocorrem essas representações narrativas...

O que se pode afirmar a partir das escritas de Walter Benjamin (2018, p. 22):

"É que a experiência que se transmite oralmente é a fonte da qual beberam todos os contadores de histórias. E entre os que as escreveram, os melhores são aqueles cujos escritos menos se afastam da fala dos muitos contadores anônimos. Entre estes últimos, além disso, há dois grupos que se interpenetram de diversas maneiras. A figura do contador só adquire sua plena corporeidade se o apresentamos sob os traços de ambos. 'Quem viaja muito, tem sempre muito que contar', diz a voz do povo, que representa o contador como aquele que vem de longe".

Assim pude observar enquanto professora, que quase todos aqueles que se propõe a arte de contar histórias, tem uma passagem difícil em sua vida, usam esse ofício como um refúgio para um mundo de sofrimento de tristezas. Fazem da vida do outro o seu alicerce para inspiração que tem como pano de fundo, uma alegria que muitas das vezes está escondida por trás de muita tristeza e sofrimento...

Para Benjamin (2018, p. 22-23):

“A real extensão do reino das narrativas, em toda sua dimensão histórica, não é pensável se não se levar em conta a intima interpenetração desses dois tipos arcaicos. Essa interpenetração foi particularmente favorecida pelas corporações de artesãos na Idade Média. O mestre sedentário e o aprendiz itinerante trabalhavam juntos no mesmo ateliê; e cada mestre fora aprendiz itinerante antes de se estabelecer em sua terra ou no estrangeiro. Se camponeses e marinheiros foram os antigos mestres da narrativa, o artesanato foi sua melhor escola. A ele, se associava o saber que vem de longe, trazido para casa por aquele que viajou muito, com o saber do passado tal como é confiado, preferencialmente ao sedentário (aquele que dá ao relato o tom da sua realidade... perto do qual o leitor gosta de se refugiar fraternalmente e de encontrar a medida, a escala dos sentimentos e dos fatos humanos normais)”.

A narrativa que ocorre no chão da escola é feita de diferentes formas, cada professor que se envolve no mundo dessa arte, o faz de forma diferenciada com 
suas turmas. Há aqueles que dão vida as narrativas através da representação de peças, em que os atores são os seus alunos. Esses alunos são caracterizados de forma a representar a história contada, ou a época desejada com falas, com roupas e com gestos. Há outros que se vestem igualmente, e montam danças que são retratos fiéis do que se pretende... Podemos observar esse fato na foto que segue das crianças que foram levadas a uma festa da EJA e do Ensino Médio representando os anos $80 .$.

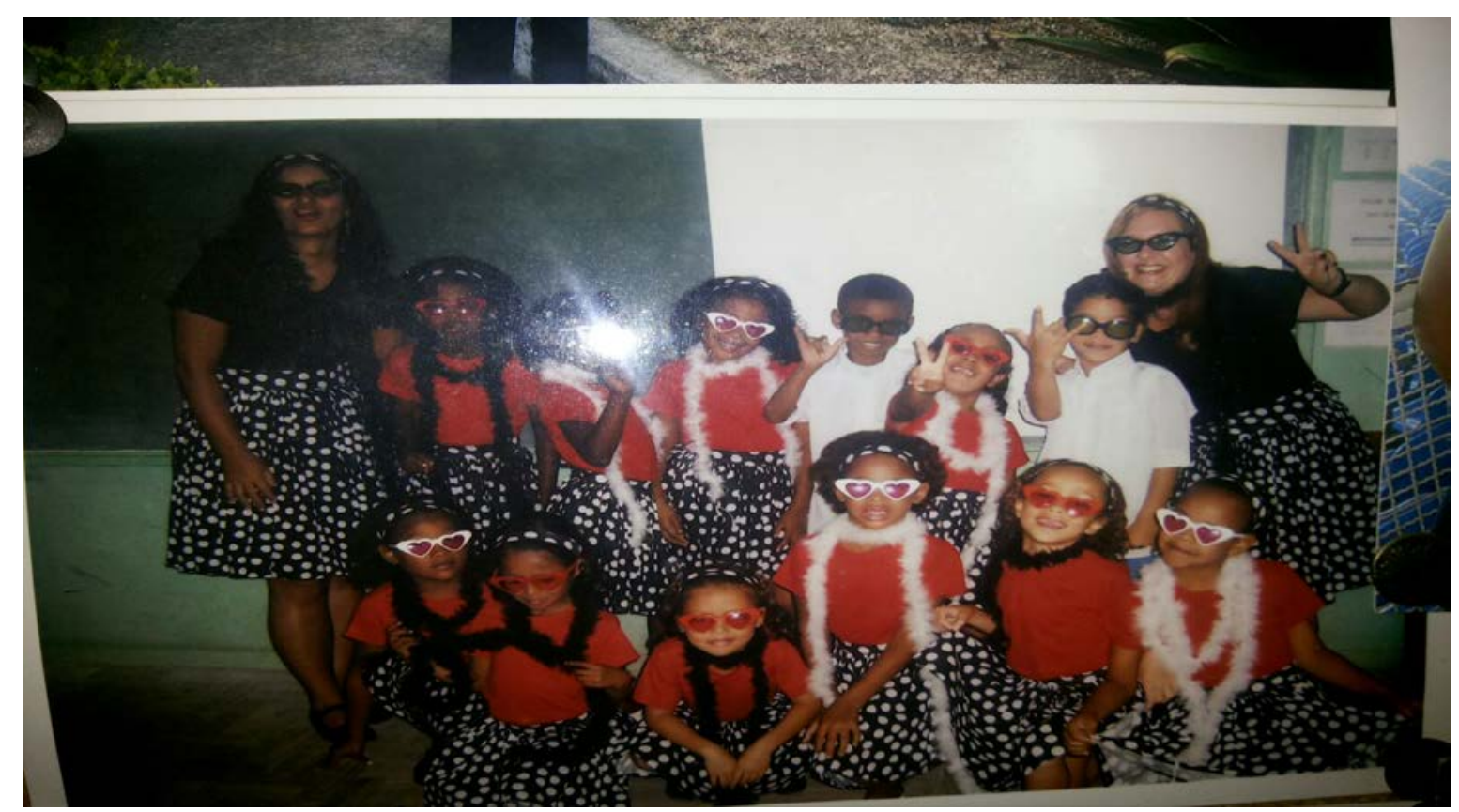

Figura 95 - Professora Maria Aparecida (Cidinha) e Eliza com alunos da Educação Infantil caracterizadas com roupas dos anos 80 - realizado no ano de 2015.

Segundo Benjamin (2018, p. 25) “A arte de contar história se aproxima de seu fim, pois o lado épico da verdade, a sabedoria, está se extinguindo”. Nas escolas interioranas a figura do contador de histórias ainda se faz presente, 'há um quê?’ na caracterização da pessoa que se presta a esse papel, que contagia o Público-alvo ao qual esse se apresenta como se percebe nas fotos abaixo. A caracterização dá vida a narrativa, envolve o público que na maioria das vezes são alunos das séries inicias do Ensino Fundamental que ajudam com as suas falas a tornar visível esse papel que, pelo que se observa nas literaturas lidas, já é uma figura quase extinta nos meios sociais da forma como se apresenta nas fotos que ilustram a atuação da professora Rosemar Pereira da Silva, que não mede esforços para que esses momentos sejam impares. 


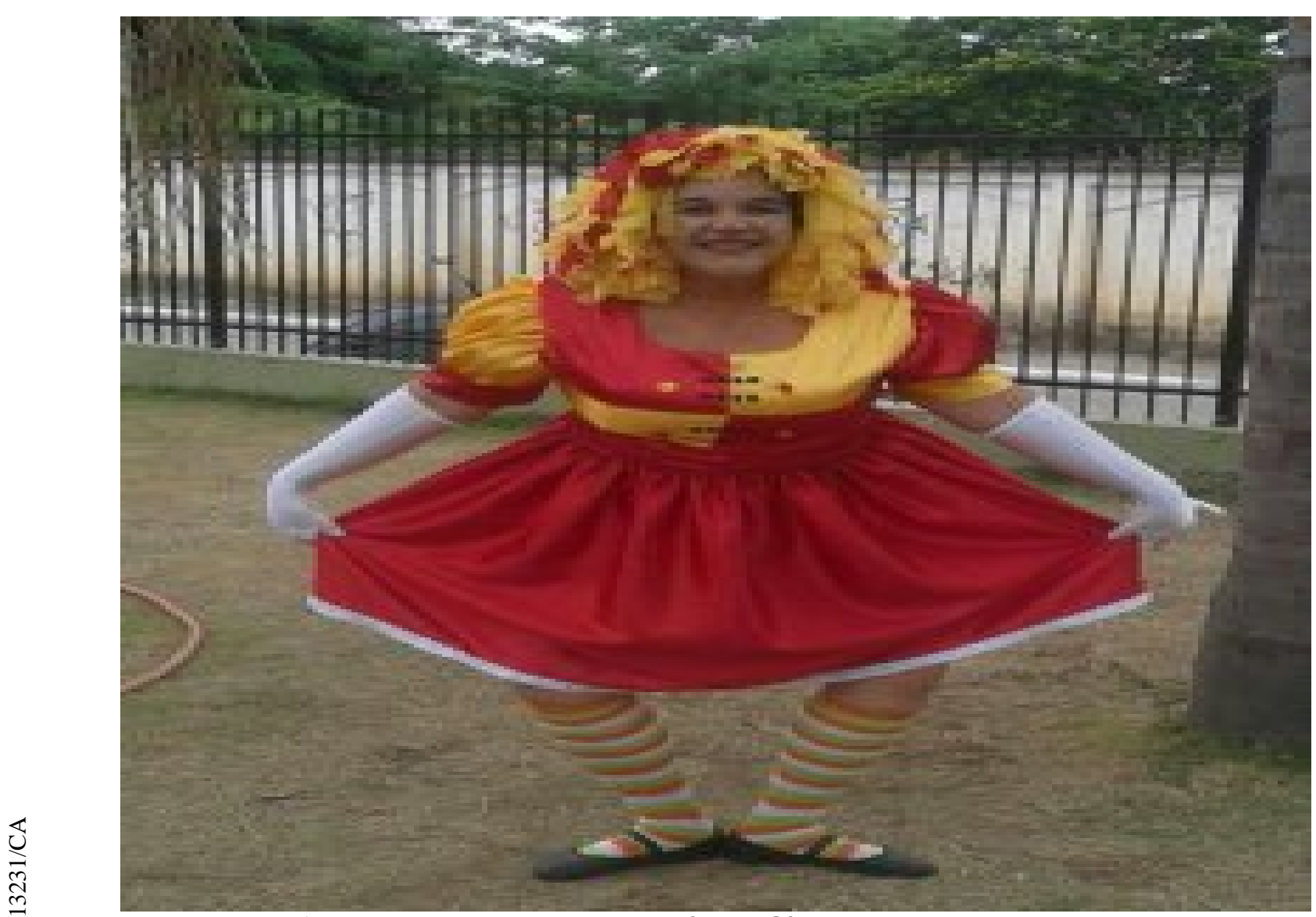

Figura 96 - Professora Rosemar vestida de Emília do Sítio do Pica Pau Amarelo.

Benjamin (2018, p. 25) afirma que:

“O primeiro indício de que a narrativa entra em declínio é assinalada pelo aparecimento do romance no início da época moderna. Nessa exposição o que distingue o romance do conto (e da epopeia num sentido estrito) é sua ligação essencial com o livro. Sendo assim, o que distingue o romance em comparação com todas as outras formas de prosa - contos de fada, novelas - é que nem provém da tradição oral nem a ela conduz. Isso o distingue em primeiro lugar do conto. O contador de histórias tira o que ele conta da sua própria experiência ou da que lhe foi relatada por outros. E ele, por sua vez, o transforma em experiência para aqueles que escutam sua história. O romancista isola-se”. 


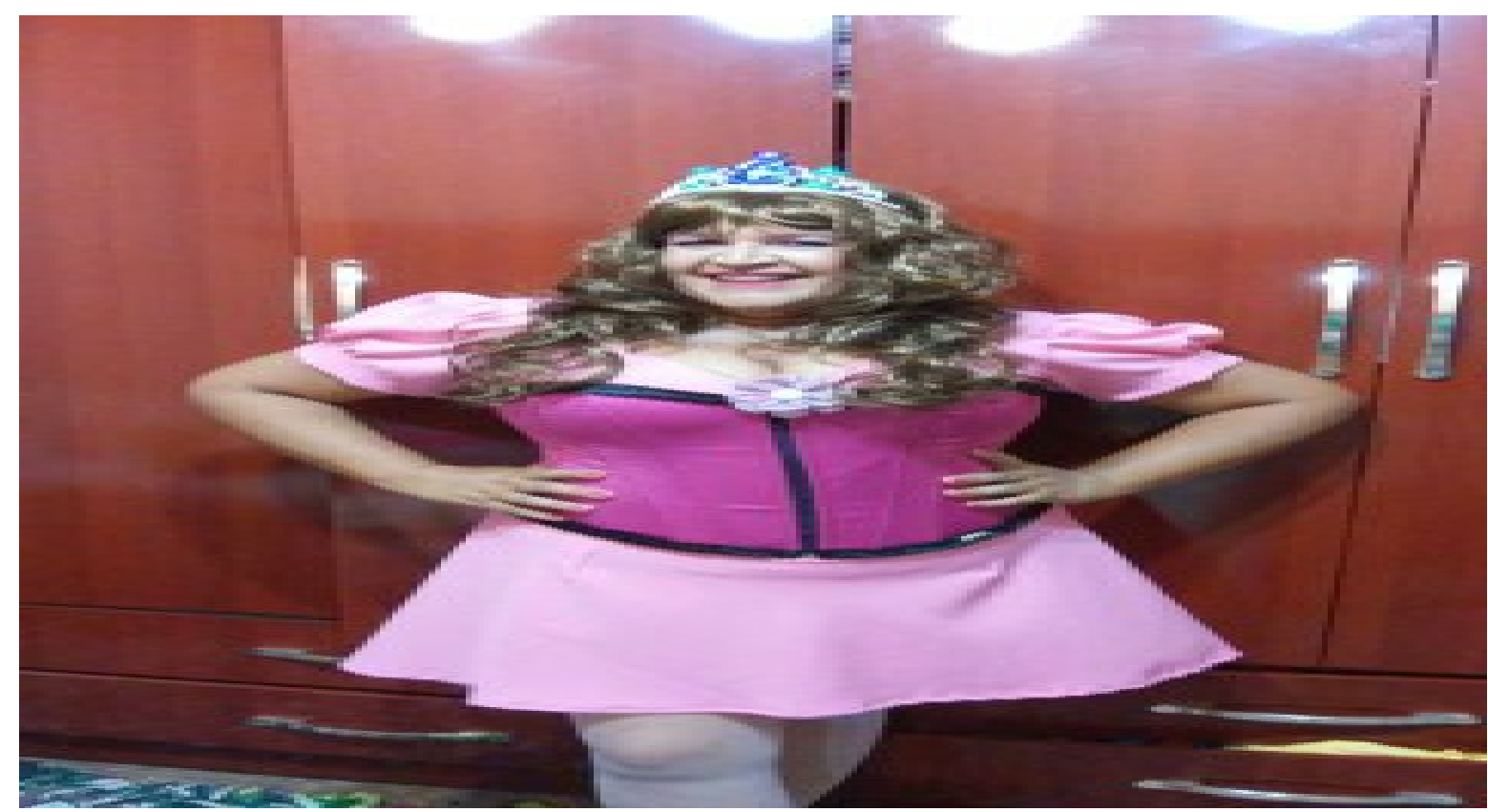

Figura 97 - Professora Rosemar representando uma Princesa.

Segundo Benjamin (2018, p. 25), “A metade da arte de contar está em despojar de explicações à história contada”. Não há uma necessidade de se provar que a história contada é verídica, pois cabe ao que conta a arte do mistério da história contada.

Benjamin (2018, p.28) afirma que:

\begin{abstract}
"Leskov conta o extraordinário, o maravilhoso com a maior exatidão, mas o encadeamento psicológico dos acontecimentos não é imposto ao leitor que fica livre para interpretar a coisa como a entende, e com isso o que é contado atinge uma amplitude que a informação não tem. Leskov frequentou a escola dos antigos. O primeiro contador de história grego foi Heródoto. Dessa forma no décimo quarto capítulo do terceiro livro de suas histórias, encontra-se um relato que muito nos ensina enquanto aprendizes”. . (BENJAMIN 2018, p.28)
\end{abstract}

A história que se apresenta no conto, mostra-nos como é o verdadeiro conto, já a informação tira o seu valor no instante em que se apresenta como nova. A informação vive apenas desse instante, pois deve render-se a ele, explicar-se nele sem perda de tempo. O conto funciona de outro modo: não se desgasta. Ele guarda em si mesmo suas forças reunidas e longo tempo depois ainda é capaz de se desenvolver. Por isso, essa história do antigo Egito ainda desperta espanto e reflexão depois de milhares de anos. (BENJAMIN 2018, p.30)

Ranciere (2015, p. 17), “nos leva a percorrer um caminho, que também traz à tona a figura do contador de histórias. E a partir das formas de visibilidade 
que um contador de histórias, quando se caracteriza viabiliza, é que surge o mistério das suas narrativas. Cria em si uma prática para o mundo das Artes”. Na maioria das vezes esse espaço é ocupado dentro da escola pela figura de um professor que se caracteriza, para criar em torno da história e da personagem a qual ele vai encarnar um foco narrativo. Segundo diz, suas histórias são lendas e fábulas contadas por alguém mais velho: uma avó, uma tia, um tio, uma mãe, um pai...

Como afirma Ranciere (2015, p.17), “antes de se fundar no conteúdo imoral das fábulas, a proscrição platônica dos poetas funda-se na impossibilidade de se fazer duas coisas ao mesmo tempo”. Para esse autor, a história da ficção leva a imaginação humana a lugares desconhecidos... Para Platão, a 'Cena de um Teatro’ que é simultaneamente espaço de uma atividade pública, e lugar de exibição dos chamados “fantasmas”, pode-se dizer assim, fantasmas do inconsciente humano porque uma aparição de um fantasma, como se pode dizer a partir daí, embaralha a partilha das identidades, atividades e espaços em que essas aparições se fazem presente. (RANCIERE 2015, p.17)

Segundo Ranciere (2015, p. 17), “para Platão há dois grandes modelos, duas grandes formas de existência e de efetividade sensível da palavra: o Teatro e a Escrita. Que a partir daí tornam-se formas de estruturação para o regime das artes em geral”. No contexto da promoção de leitura através da contação de histórias, nas escolas públicas 'Panaro Figueira' e 'Aurelino G. Barbosa' que servem como arcabouço para a construção dessa dissertação, esses fatos são feitos de forma a incentivar a leitura e a escrita; tornando-as um dos muitos caminhos para a efetivação do conhecimento. 


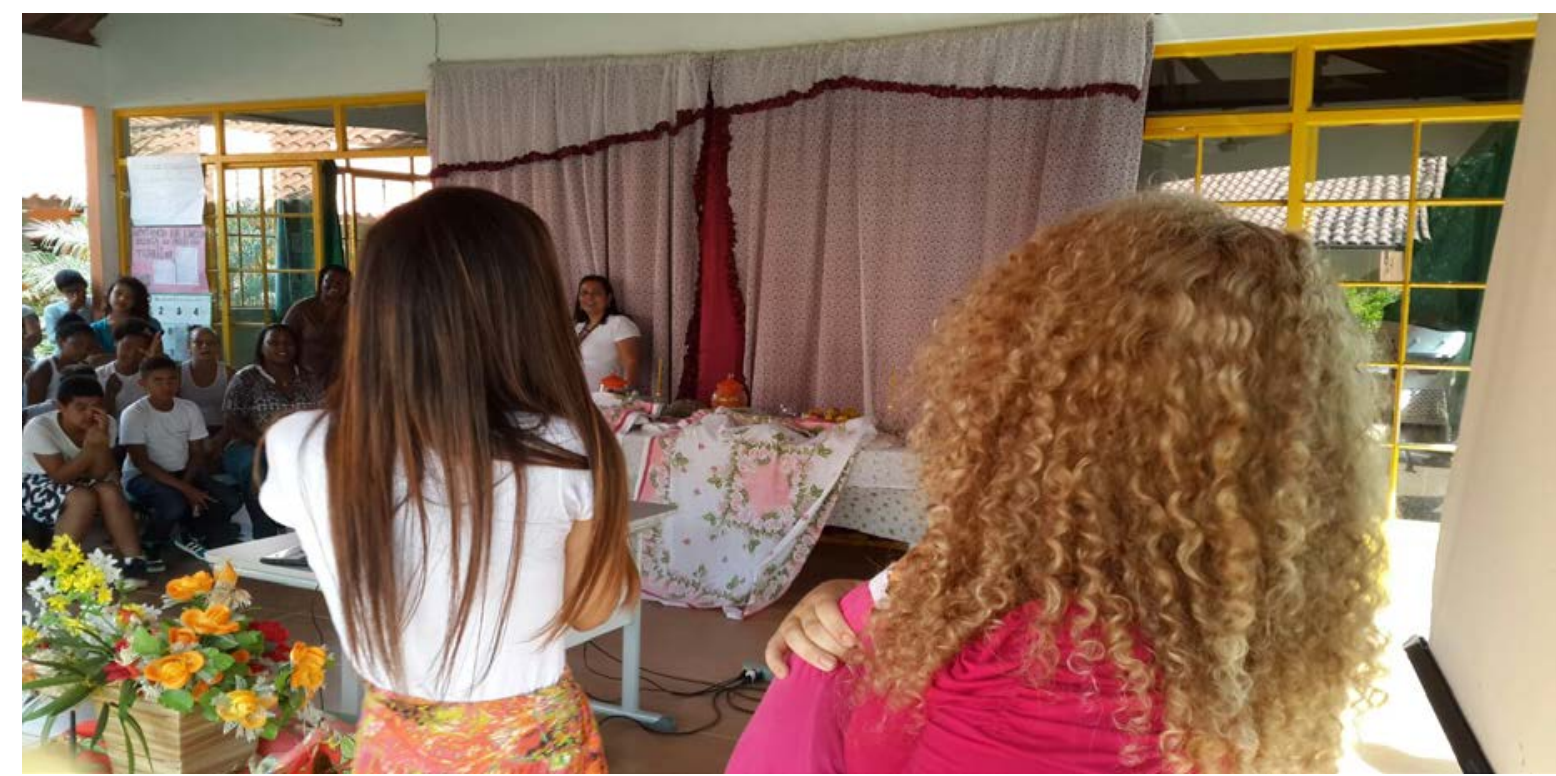

Figura 98 - apresentação de peça teatral 'O rico e o pobre' pelas alunas do Ensino Fundamental.

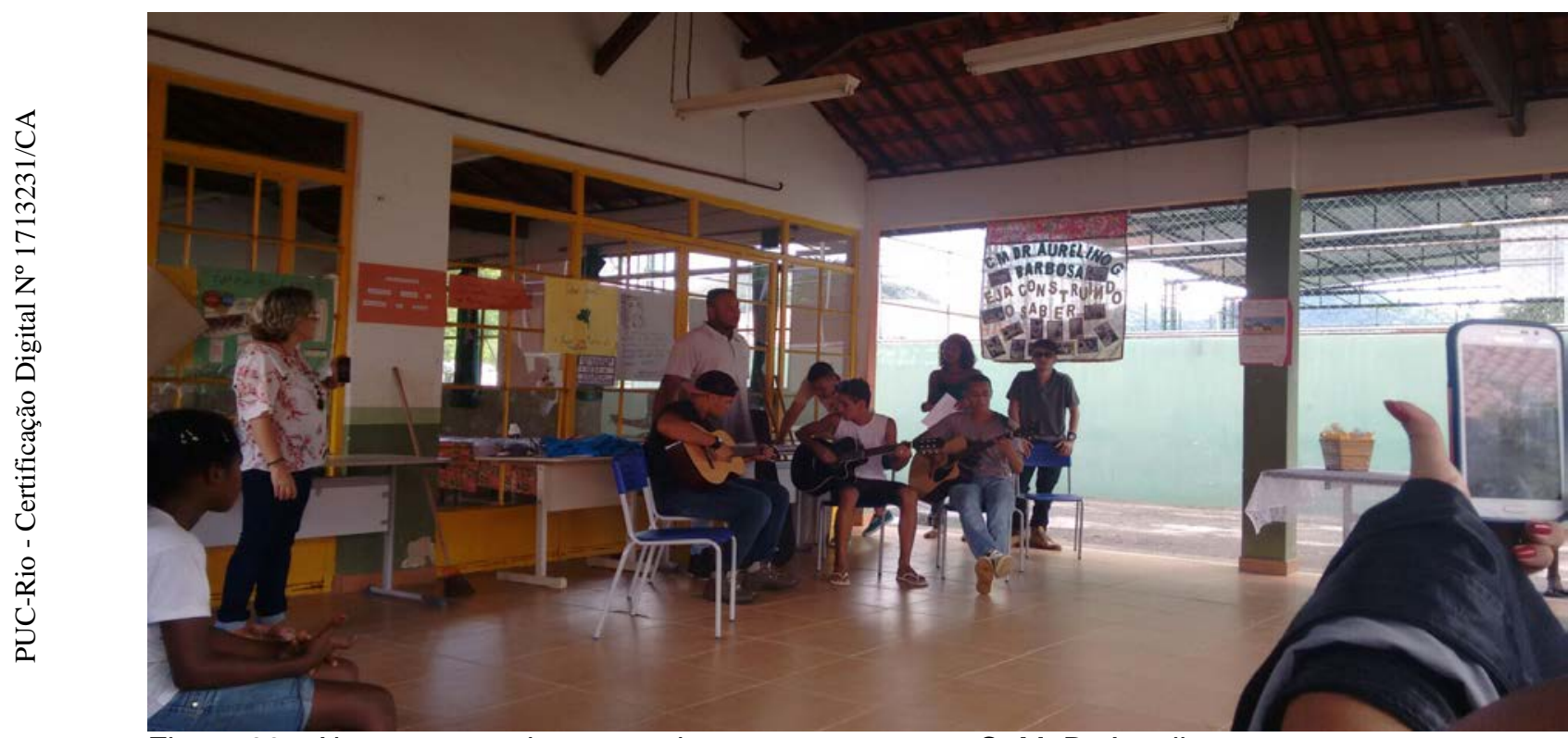

Figura 99 - Alunos cantando e tocando em um evento no C. M. D. Aurelino.

Sendo assim, o desenvolvimento dessas atividades no espaço escolar torna-se o caminho para o crescimento e criação do conhecimento através da interpretação e representação de músicas e narrativas de leitura.

Dessa forma, mesmo estando esses “artistas comunitários” sujeitos ao anonimato por indeterminação da exposição de suas identidades, da colocação de suas palavras em apresentações de recitais de poesias no espaço escolar, eles extrapolam esse espaço ao serem levados a eventos que acontecem em espaços 
externos com avaliadores anônimos ampliando assim os seus espaços e os seus tempos para apresentação.

Ranciere (2015, p. 18), nos fala da terceira forma Platônica de ver a arte; uma forma de arte, que vem através da 'coreografia'. Essa é a forma coreográfica da escola que dança e canta sua própria unidade, apresentando-se para a comunidade.

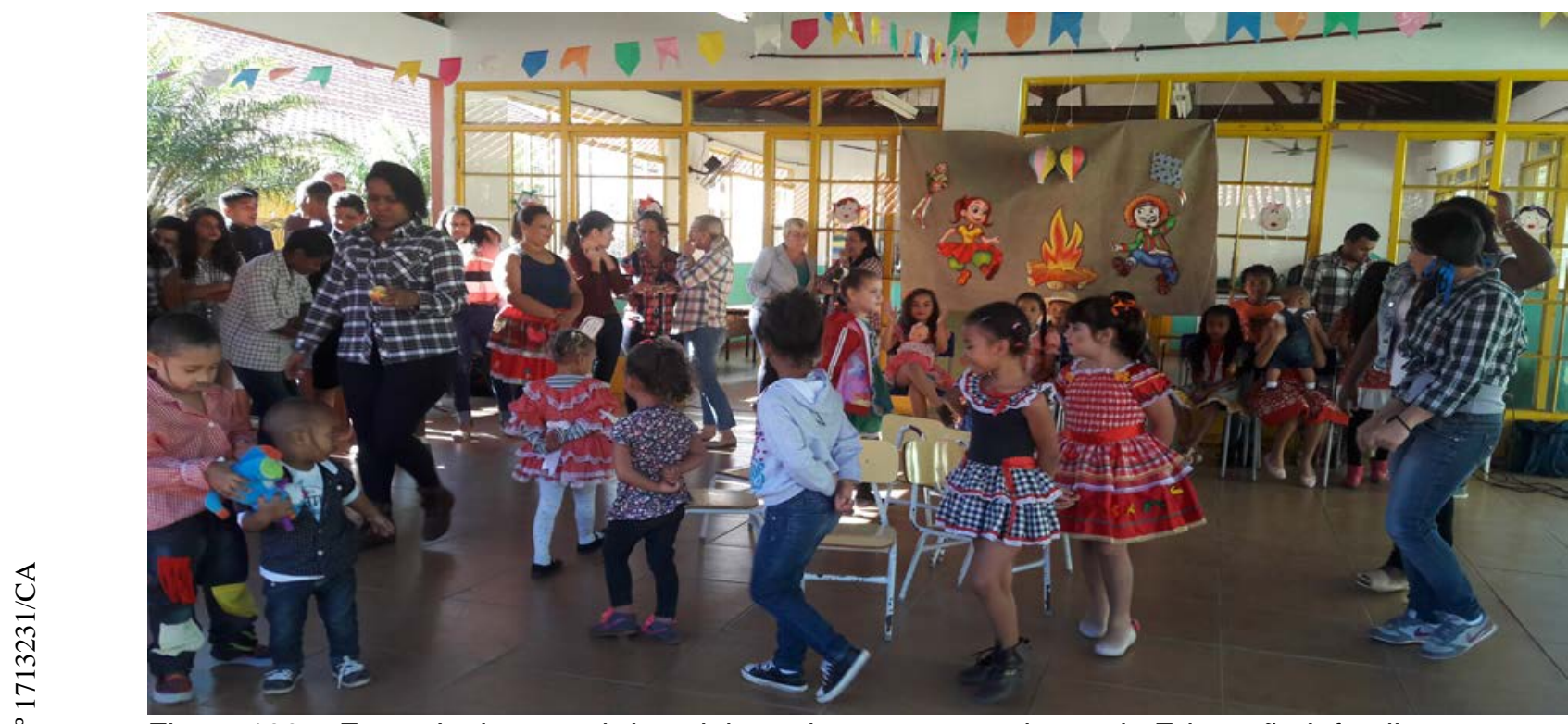

Figura 100 -Festa Junina com brincadeira e dança com os alunos da Educação Infantil.

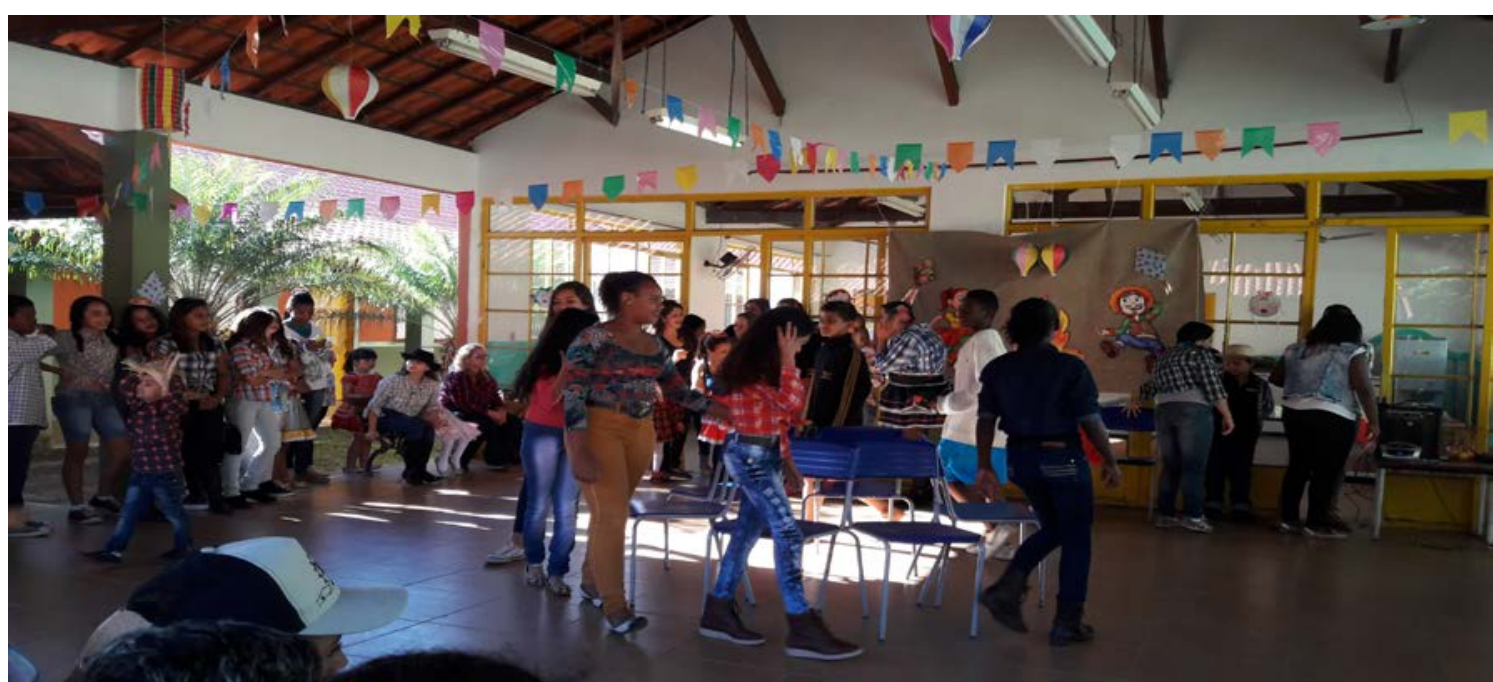

Figura 101 - Festa Junina brincadeira e dança com alunos do Ensino Fundamental. 


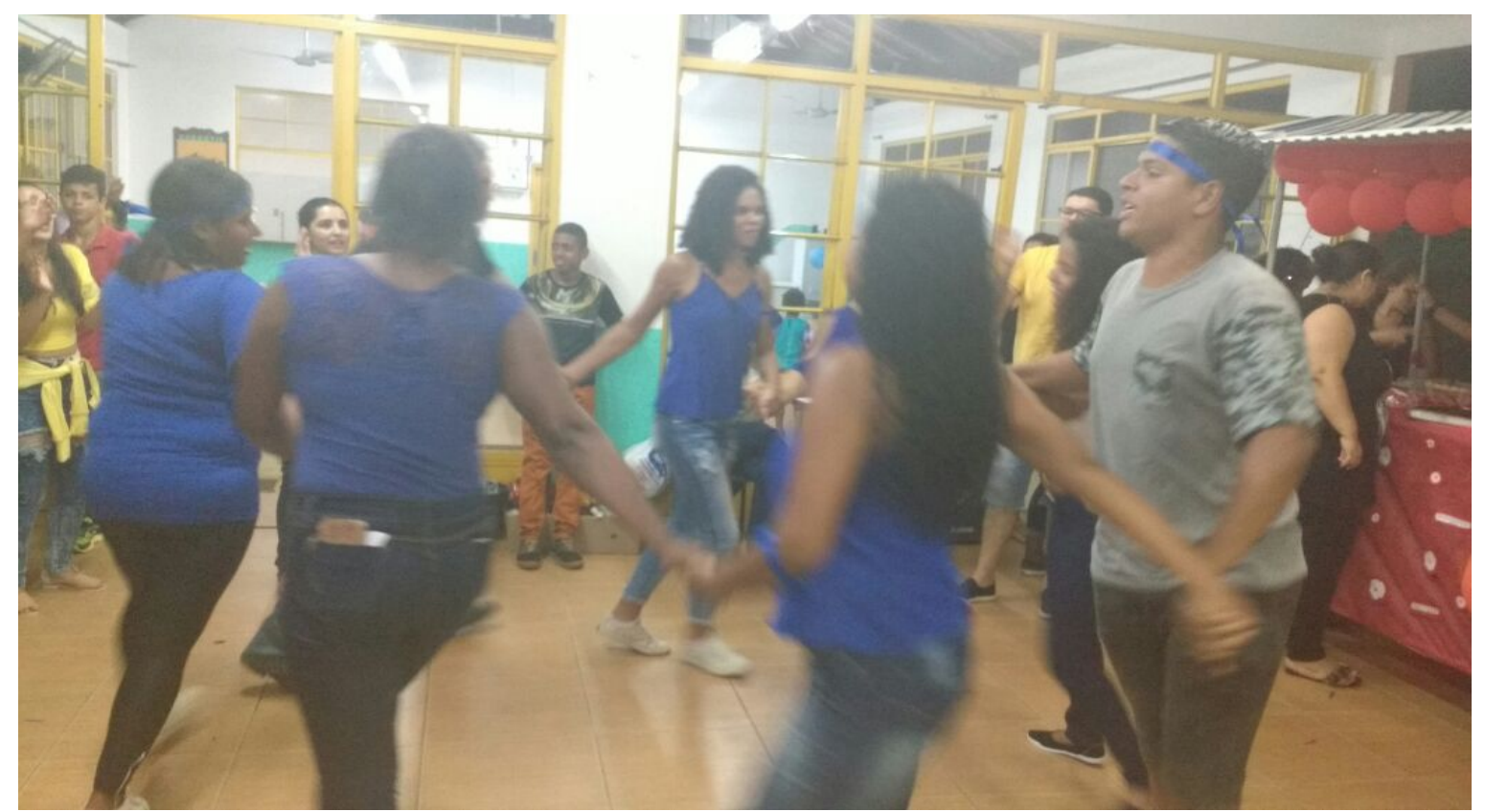

Figura 102 - Tarefa coreografada da gincana da amizade (Ensino Médio e Educação de Jovens e Adultos).

Nesse espaço, os movimentos dos corpos, dividem-se para ele em dois modelos antagônicos. De um lado, para Platão, há o movimento dos 'Simulacros' da cena teatral, ofertados para identificação do público. De outro, o movimento autêntico nas danças com coreografias que retratam o movimento próprio dos corpos comunitários.

Essas três formas de Arte 'Teatro, escrita e coreografia', podem ser considerados pela descrição de Ranciere (2015, p. 18) 'como três formas de partilhas do sensível', estruturando assim, a maneira pela qual as artes podem ser percebidas e pensadas como Arte e como formas de inscrição do sentido da comunidade. Essas formas pode-se dizer, definem a maneira como obras ou performances 'fazem política', quaisquer que sejam as intenções que as regem, os tipos de inserção social dos artistas (nesse caso dos alunos que as praticam, ou o modo como as formas artísticas refletem estruturas ou movimentos sociais).

\section{2}

\section{Projeto de Incentivo a Leitura}

Esse projeto foi desenvolvido no Colégio Municipal Dr. Aurelino Gonçalves Barbosa, que tinha como diretora a professora Sandra Rosa Jachinto. 
Por ser uma gestora participativa e atuante sempre procurou apoiar todos os trabalhos que eram desenvolvidos.

Esse projeto foi idealizado e desenvolvido por mim, tendo como meta levar os alunos dessa escola a se tornarem leitores mais efetivos. Segue abaixo as diretrizes desse projeto:

Plano de Ação Desenvolvido Dentro do Projeto Político Pedagógico: EXPO EJA

Incentivo A Leitura

Palestrante Convidado: Escritor Jeferson Sarmento

\section{Ações do projeto em execução}

\section{Justificativa Do Projeto}

O projeto surgiu em face das dificuldades apresentadas por nossos alunos da EJA (Educação de Jovens e Adultos) em relação às atividades de leitura e escrita, mais especificamente interpretar e reescrever textos contextualizando-os. Fato esse que pode contribuir de forma significativa para aumentar o nível de aprovação em Língua Portuguesa, como também melhorar o baixo desempenho dos alunos também em outras áreas do conhecimento numa ação que englobou a interdisciplinaridade.

\section{Relevância}

Tornou-se relevante à implementação de um projeto que propiciasse uma ação pedagógica produtiva que trabalhasse de forma articulada, simultânea e lúdica a leitura e a produção escrita, visto que o contato mais sistemático que nossos alunos têm com o texto literário são ofertados pela escola, cabe à mesma assumir seu papel de mediadora na formação de leitores e escritores críticos, criativos e autônomos, proporcionando o acesso ao diferentes gêneros literários e textos mais variados.

\section{Trabalho desenvolvido pela turma da EJA}

Foi desenvolvido um plano de ação do PPP da escola "Uma releitura" de diversos tipos de textos, voltados para a reescrita e interpretação pelos alunos da 
EJA com a parceria do Ensino Médio fazendo a releitura dos livros do autor Jeferson Sarmento.

Ações Praticadas

- Viagem ao Mundo da Leitura

\section{Objetivo do Projeto}

- Melhorar a qualidade do processo ensino-aprendizagem;

- Elevar o nível de aprendizagem dos alunos;

- Assegurar a melhoria do processo ensino aprendizagem através da leitura de diferentes tipos de textos e livros.

Indicadores que ocasionaram essa ação:

- O déficit de conhecimento nos anos anteriores;

- A dificuldade de ler, interpretar e escrever dos alunos;

- A intenção de melhorar o rendimento escolar nas diferentes áreas do conhecimento.

\section{CRONOGRAMA EXPOEJA}

Noite de Autógrafos e Leituras "Revelando Talentos"

Música de Abertura - Trem Bala

Fala da Direção - Sandra Rosa E Eliza

Fala da Coordenadora da EJA- Josete

Apresentação do Autor - Jeferson Sarmento

Alunos do $3^{\circ}$ Ano do Ensino Médio

Importância da Leitura

Biografia do Autor

Palestra - Autor Jeferson Sarmento

\section{MESA REDONDA}

Apresentação dos Trabalhos Da EJA

Turma Professora Deisemar

Turmas do $2^{\circ}$ Segmento da EJA 
Peça de Teatro - Atualidade

Turma $2^{\circ}$ Ano do E.M.

Apresentação das Músicas

Do $1^{\circ}$ Ano Ensino Médio com a participação do $3^{\circ}$ Ano do Ensino

\section{PALESTRA ESCRITOR JEFERSON SARMENTO}

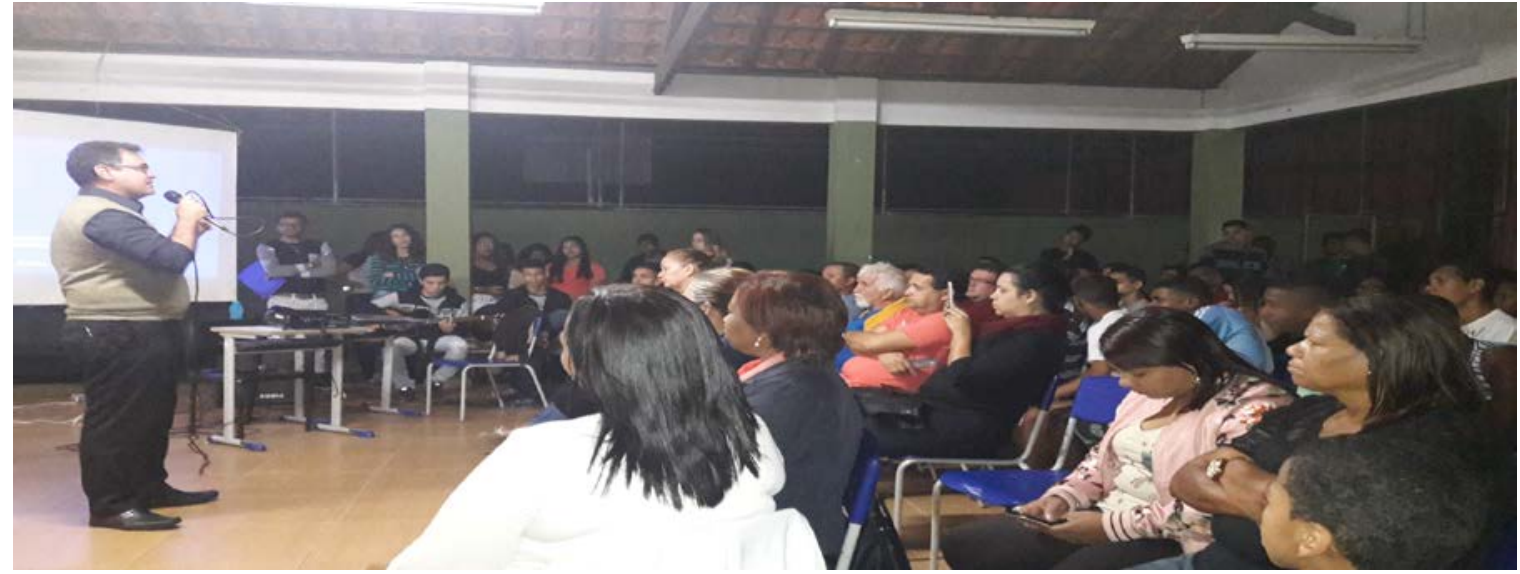

Figura 103 - escritor e autor Jeferson Sarmento.

\section{METAS}

- Fornecer subsídio ao professor e ao aluno para melhorar o desenvolvimento das ações pedagógicas no espaço escolar através da leitura.

- Levar os alunos a Bienal do Livro para que eles tivessem acesso a diferentes fontes Literárias.

E aqui terminam esses relatos. Não há no meu entender o que fazer de melhor para esses alunos, atualmente estamos desenvolvendo desde o II segmento do Ensino Fundamental, até o Ensino Médio, simulados. O investimento que fazemos em qualidade para a Educação do C. M. Dr. Aurelino Gonçalves Barbosa tornou-se o nosso viés enquanto transformadores de vida. Sabemos que ainda não conseguimos alcançar o ideal desejado, mas estamos buscando esse ideal através dessa dinamização de eventos através de aulas diversificadas e práticas de ensino que extrapolem os muros da escola. 


\section{Conclusão}

O caminho percorrido aqui levou a uma curiosidade maior pelo trabalho com esses textos, desses diferentes autores, pois eles abordam de forma diferenciada na maioria das vezes, temas recorrentes que mostram os diferentes olhares que podem ser dados ao mesmo assunto proposto. Os temas que se encontram dentro do contexto perceptível, mostrou que se pode identificar no trabalho com a cultura de um povo que são: a imagem, a tradição, o testemunho $e$ as memórias... Um discernimento maior para o que se pretendeu aqui como instrumento para aperfeiçoamento no espaço escolar de diferentes formas de aprendizagens de leitura e interpretação.

Memórias e imagens sim, pois são o maior ápice do discurso feito aqui, porque são as imagens que cristalizam o poder do tempo, e que fazem desse tempo uma porta aberta para o caminhar da humanidade. Sendo assim, aqui se efetivou essa dissertação de mestrado que demonstrou que é no chão da escola que na maioria das vezes surge a contextualização de mundo de crianças, jovens e adultos; pois é através da escola que muitos alunos descobrem sua vocação, e se integram em relacionamentos interpessoais no meio social que os preparam para a vida.

Essas escritas não se findam aqui, pois o material que se tem como arquivo vivo de experiências e práticas pedagógicas podem servir de aparato para outras escritas.

Escrever sobre essas práticas e experiências a princípio para mim foi um tanto difícil, pois muitas lembranças guardadas na memória conduzem a eventos que foram difíceis. O que se tem de mais importante nisso tudo, é que desenvolver trabalhos práticos com base em projetos, tornam as aulas do dia a dia enriquecedoras, e mais estimulantes; pois fazem da prática pedagógica uma vertente para novas aprendizagens, novos laços de integração e amizade entre escola-aluno-comunidade, e ajudam a criar novas perspectivas em relação a Educação. 
A Educação deveria ser vista por todos como o caminho para uma perspectiva maior de vida, no intuito de melhorar a aprendizagem do indivíduo, independente de sua classe social. Ainda há escolas públicas que primam pela qualidade em Educação e para a Educação. O viés maior dessas atividades é fazer do espaço escolar um patamar para novas aprendizagens efetivas, e novos relacionamentos socioemocionais e interpessoais.

Ler e escrever para muitos alunos é a realização de um sonho adormecido, tanto para as primeiras séries do Ensino Fundamental como para séries posteriores, pois alguns de nossos alunos escrevem mas não interpretam, ou interpretam mas não escrevem. Isso é um fato que assusta, pois podem ser considerados analfabetos funcionais. Agora para as crianças ler é o descobrimento do mundo concreto, pois a leitura dá vida a seu imaginário criativo. Já os alunos do ensino noturno retornam a escola por necessidade de ter um diploma, para conseguir um emprego melhor. Grande parte desses alunos, ficaram afastados da escola por muitos anos, devido a fatos ocasionados por diferentes situações, algumas delas adversas as suas vontades. Atualmente esses alunos retornaram ao ensino noturno, em busca de qualificação pessoal. Há também uma grande quantidade de adolescentes que por necessidade trabalham durante o dia, pois precisam ajudar nas despesas das suas casas.

Uma necessidade que deveria ser prioridade dos governos seriam as capacitações para professores, pois para se ter uma qualidade melhor para a sua clientela, esses deveriam ter acesso a melhores condições de trabalho, tendo assim possibilidade de se capacitar para melhorar o nível de ensino nas escolas públicas que eles atendem.

Quando o professor está aberto para novas aprendizagens e conhecimento, esse possibilita a seus alunos novas perspectivas de aprendizagens e conhecimentos.

Todos os trabalhos apresentados culminaram em algum passeio ou evento... A gincana da copa do Colégio Doutor Aurelino Gonçalves Barbosa, levou-os ao circuito dos jogos da Copa no Rio de Janeiro, que foi a visita ao Maracanã antes dos jogos da copa, passeio oferecido pela coca-cola. O projeto “Incentivo à leitura” levou-os a ‘Bienal do Livro’ no Rio de Janeiro. 
Os trabalhos desenvolvidos pelos alunos na Escola Municipal Panaro Figueira, levou-os a visitação ao Cristo Redentor, ao Pão de Açúcar, a Petrópolis... Não se pode esquecer que esses alunos moram na periferia da cidade do Rio de Janeiro, na baixada fluminense e em Região Serrana.

Não se esgota aqui as ações, e os projetos mostrados; pois todo o trabalho com escrita e leitura faz parte de ações que são desenvolvidas consecutivamente e anualmente pelo menos no espaço do C. M. Doutor Aurelino G. Barbosa, por mim enquanto professora com a ajuda de alguns colegas em um trabalho interdisciplinar.

Após fazer esse mestrado na PUC-RIO, muitas vivências foram acrescentadas a esses eventos. A forma de ler diferentes literaturas ampliaram meus horizontes com relação a essas atividades. As escolas públicas na maioria das vezes já recebem planejamentos de suas atividades de pessoas que não se atualizam há muito tempo. Por isso em alguns momentos foi difícil o acesso a alguns materiais que seriam essenciais para a aplicação de práticas diversificadas pelo menos no que tange a Escola Municipal Panaro Figueira; já no Colégio Municipal Doutor Aurelino G. Barbosa, temos uma secretária de educação que é uma parceira. Os eventos fluem de uma forma mais ampla e diversificada...

A partir dessas práticas, diferentes leituras de mundo podem ser aplicadas como instrumento de aprendizagem para os alunos do município de Pirai. Há um envolvimento maior do poder público, dessa forma como se pode observar através das fotos que foram mais frequentes nesse espaço escolar, temos alunos mais abertos à aprendizagem.

Há um jornal no bairro onde essa escola se situa que registra o desenvolvimento e acompanha as histórias de vida de nossos alunos após a conclusão do Ensino Médio, isso faz com que a escola tenha mais visibilidade. O que se pode perceber, é que o C. M. Dr. Aurelino G. Barbosa em Piraí tornou-se o espaço de promoção de eventos da comunidade; esse é o lugar em que a comunidade se dirige em busca de aprendizagem e distração através dos eventos promovidos pelos professores, diretores, funcionários com a participação dos alunos em grande escala e de suas famílias. Todos os projetos no final se transformam em uma grande confraternização... 
Referências bibliográficas

ARENDT, Hannah. Entre o passado e o futuro. São Paulo: Perspectiva, 2000.

BEISEGEL, Celso de Rui. Política e Educação Popular: a Prática de Paulo Freire no Brasil. São Paulo: Ática, 1982.

BENJAMIN, W. Rua de mão única. Trad. Rubens Rodrigues Torres Filho e José Martins Barbosa. São Paulo: Brasiliense, 1995. (Obras escolhidas, v. 2)

BOTELHO, S. D. História, ficção e memória nos espaços fantásticos de A Jangada de Pedra: uma (a)ventura ibérica - Universidade Federal de Uberlândia UFU, 2012.

BRASIL. Secretaria de Educação Fundamental. Parâmetros Curriculares Nacionais Apresentação dos temas transversais, ética / Secretaria de Educação Fundamental, Brasília: MEC/SEF, 1996.

BRASIL, Ministério da Educação e do Desporto. Parâmetros Curriculares Nacionais para o Ensino Fundamental. Brasília: MEC-SEF, 1995 (Versão Preliminar).

BRASIL. Proposta Curricular para a Educação de Jovens e Adultos. Brasília: MEC, 1999.

CHAUI, Marilena. Convite à filosofia. São Paulo: Ática, 2005.

DELEUZE. Gilles. Lógica do sentido. 4a ed. São Paulo: Perspectiva, 2000. pp.259-271. (Estudos) - "Platão e o Simulacro".

DEMO, Pedro. Educação \& conhecimento. Vozes; Rio de Janeiro - 2000.

DIDI-HUBERMAN, Georges. Diante do tempo - Tradução: Alberto Pucheu história da arte e anacronismo das imagens...

DIDI-HUBERMAN, Georges. Atlas Como Levar o Mundo nas Costas - 26 de Novembro de 2010 - 28 de Março 2011. (Museu Nacional Centro de Arte Reina Sofia, Madrid)

DIDI-HUBERMAN, Georges. A Dupla Distância in O que Vemos e o Que nos Olha/ Tradução: Paulo Neves - Coleção TRANS - Editora 34. $2^{\mathrm{a}}$ impressão, São Paulo: 2014.

FERREIRO, Emília. Reflexões sobre Alfabetização. Tradução Horácio Gonzáles et al., ed. 24 ed. Atualizada. São Paulo: Cortez, 2001. 
FOUCAULT, Michel. As unidades do discurso. In A arqueologia do Saber. Rio de Janeiro: Forense Universitária, 1978. p. 23-34

FREIRE, Paulo. Educação como Prática da Liberdade. Rio de Janeiro: Paz e Terra, 2002.

FREIRE, Paulo. Educação e Mudança. Tradução de Moacir Gadotti e Lillian Lopes Martin. Rio de Janeiro: Paz e Terra, 1979.

FREIRE, Paulo. Política e Educação: ensaios. 5 Edição. Coleção Questões de Nossa Época, v. 23. Ed. Cortez, São Paulo: 2001.

FUCK, Irene Terezinha. Alfabetização de Adultos. Relato de uma experiência construtivista. $2^{\text {a }}$ ed. Petrópolis: Vozes, 1994.

GONZÁLEZ, Fernando Jaime. Práticas pedagógicas em Educação Física: espaço, tempo e corporeidade/ Fernando Jaime González e Maria Simone Vione Schwengber; Ilustrações de Eloar Guazzelli - Erechin; Edelbra, 2012.

HALBWACHS, M., Les cadres sociaux de La mémoire. Paris: Alean,1990.

HALBWACHS, M., La mémoire collective. Paris: Presses Universitaires de France, 1990.

HAM, Cristopher \& HILL Michael. The Policy Process in the Modern Capitalist State. Londres, 1993.

LAJOLO, Marisa. Do mundo da leitura para a leitura do mundo - $2^{\mathrm{a}}$ edição, Editora Ática, São Paulo, 1994.

LE GOFF. Jacques, História e memória, tradução Bernardo Leitão - $1^{\text {a }}$ Edição Campinas, SP. Editora UNICAMP, 1990. (Coleção Repertórios)

LE GOFF. Jacques, História e memória, $7^{a}$ edição revista - Tradução Bernardo Leitão, Irene Ferreira e Suzana Ferreira Borges - Campinas, SP. Editora UNICAMP, 2014.

LEVI-STRAUSS, C. Anthropologie Structurale. Paris: Plon, 1958.

LEVI-STRAUSS, C. et al, Anthropologie, histoire, idéologie”. L'Homme, XV, 3-4, 1975, pp. 177-88.

LIMA, Alceu Amoroso. 'Poesia Infantil' in: Estudos. 4ª série, Rio de Janeiro, Ed. Centro D. Vidal, s.d. p. 114.

MINAYO, M.C. O desafio do conhecimento. Pesquisa qualitativa em saúde. São Paulo- Rio de Janeiro: Hucitec-Abrasco, 2003.

MISSAC, Pierre. Passagem de Walter Benjamin. Trad. Lilian Escorel. Editora Iluminuras LTDA, São Paulo, 1998. 
MODINGER. Carlos Roberto. Práticas pedagógicas em Artes: espaço, tempo e corporeidade... [ et al.]; Ilustrações de Eloar Guazelli. - Erechin; Edelbra, 2012.

OLIVEIRA, L. C. F. Escola e família numa rede de (des)encontros: um estudo das representações de pais e professores. Cabral Editora, São Paulo - 2002.

OLIVEIRA et al. Gestão, Coordenação e orientação educacional: trabalho integrado para o bom funcionamento da escola. Revista Pesquisa \& Criação Volume 10, Número 1, Janeiro/Junho de 2011. p. 51-66.

PIMENTA, Sema Garrido. Saberes pedagógicos e atividades docentes/ textos de Edson Nascimento Campos (et al) - 3ª ed. São Paulo: Cortez, 2002.

RANCIERE, Jacques. A partilha do sensível: estética e política; Tradução Monica Costa Netto - São Paulo - EXO experimental org.: Editora $34-3^{\mathrm{a}}$ reimpressão - 2015

RIBAS, Maria Cristina Cardoso; FONTOURA, Helena Amaral da, \& WILSON, Victoria (organizadoras) Escritas de si: Conficções de professores: uma experiência com a primeira turma do ProfLetras da Faculdade de Formação de Professores da UERJ - Livro 3, Niterói: Intertexto, 2017. (Escritas de Professores)

RIBEIRO, Vera Maria Masagão. Educação de Jovens e Adultos: Proposta Curricular para o $1^{\circ}$ Segmento do Ensino Fundamental (coordenação e texto final); Ilustração de Fernandes I. - São Paulo: Ação Educativa; Brasileira; Brasileira: MEC, 1997.

ROSA, Allan da. Pedagoginga, Autonomia e Mocambagem - 1. ed. - Rio de Janeiro: Aeroplano, 2013. 292 p. (Tramas urbanas).

SALTO PARA O FUTURO - Educação de Jovens e Adultos / Secretaria de Educação a Distância. Brasília: Ministério da Educação, SEEL, 1999.

SILVA, Norma Maria Jacinto da. Os Fios da Memória e da História em de Rios Velhos e Guerrilheiros: O Livro dos Rios, Editora UFRJ, Rio de Janeiro, 2009.

SOUZA, Maria de Lourdes - Do córrego ao rio, o percurso de quem lê e escreve no chão de sua terra a própria história e a de sua gente - Orientadora: Rosana Kohl Bines - 2014. 
Anexos

\section{DESCRIÇÃO DOS PROJETOS}

\section{GINCANAS EDUCATIVAS E PROJETOS DE LEITURA}

\section{A - COPA AURELINO 2014}

Data do evento: 4 de junho de 2014 - Horário:12:20 às 17:00

PROGRAMAÇÃO DA GINCANA:

12:20- Hino nacional

12:40 - Fala da Direção

12:50- Apresentação do grito de guerra das equipes

13:00- Apresentação de dança ( $8^{\circ}$ ano)

13:10- $1^{\circ}$ Jogo: Futsal masculino ( $6^{\circ}$ ano $\times 7^{\circ}$ ano $)$

13:40- Apresentação de dança ( $7^{\circ}$ ano)

13:50- $2^{\circ}$ Jogo: Futsal feminino (time misto)

14:15- Festival de embaixadas

14:20- Apresentação de dança ( $6^{\circ}$ ano)

14:30- Intervalo

14:50- $3^{\circ}$ Jogo: Futsal feminino (time misto)

15:20- Chute no alvo

15:40- Quiz sobre futebol

16:00 - Disputa de dedobol

16:10- $4^{\circ}$ Jogo: Futsal masculino ( $8^{\circ}$ ano $\times 9^{\circ}$ ano $)$

16:40- Apresentação de dança ( $\left.9^{\circ} \mathrm{ano}\right)$

17:00- Encerramento ( premiação do grupo de dança vencedor /agradecimento)

MATERIAIS NECESSÁRIOS:

- Caixa amplificada

- Microfone

- Pen drive com músicas (inclusive hino nacional)

- 3 bolas de futsal

- 4 arcos

- Fita crepe e barbante

- Apito

- Cartão vermelho e amarelo

- Cronômetro

- Lápis e papel para anotações

- Material impresso para Quiz

- 4 moedas de 5 centavos

- 2 tabuleiros de dedobol

- 1 caixa de Bis para artilheiro

- 1 caixa de bombom para melhor grupo de dança

- 24 medalhas para futsal 


\title{
PALESTRAS
}

\section{1 - TEMA: POR QUE CUIDAR DO MEIO AMBIENTE}

\author{
RECICLAR
}

É importante que se trate, colete e transforme os resíduos sólidos, pois, estes quando transformados são capazes de se transformar em fonte de renda para pessoas carentes.

O meio ambiente hoje sofre com a agressão do homem, pois, este de forma lenta mais precisa ocasiona uma série de problemas a natureza.

A Coleta Seletiva e a reciclagem hoje, deve vir como forma de solução para o problema de acúmulo de lixo indesejável, em lugares tão importantes como nas Escolas e Adjacências, preservando a natureza e o meio ambiente.

\section{A USINA}

A parceria com uma usina é importante pois, esta pode receber em seu bojo todo o material recolhido. Os cooperativados de uma Usina normalmente conhecem cada tipo de material e sabem tria-los e compactá-los por classificação.

Se nós de cada comunidade, não nos engajarmos em defesa do meio ambiente, será quase impossível conseguirmos amenizar a poluição do mundo daqui a alguns anos.

Quando se trabalha em prol de se reciclar os resíduos sólidos, torna-se mais fácil o tratamento pela natureza destes materiais, pois estes são reaproveitados deixando de poluir a natureza.

No Brasil a maioria dos governantes $\mathrm{n}$ ao se preocupam com o destino final do lixo urbano.

Em Seropédica, já esta sendo desenvolvido um projeto que visa amenizar o impacto dos lixões sem tratamento que acabam contaminando os lençóis freáticos por um líquido que é proveniente do lixo.

A poluição do ar também acontece quando se põe fogo nos lixões..

Então há realmente a poluição do solo, do ar e das águas.

Quando há interesse por parte dos governantes, estes procuram tratar o lixo construindo aterros sanitários que são capazes de amenizar o problema ambiental de contaminação do solo, da água e do ar pelo lixo, seja de que forma for.

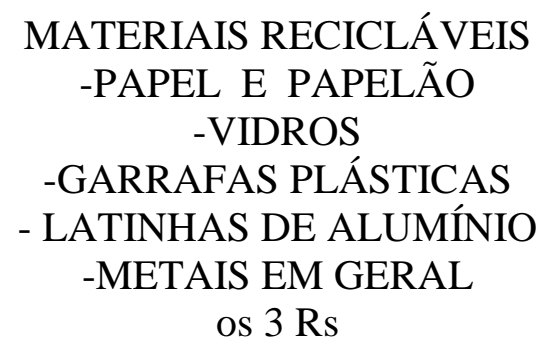




\section{2 - PALESTRAS APLICADAS NO PROJETO DE COLETA SELETIVA}

As palestras serão ministradas nas organizações utilizando-se sempre recursos audiovisuais e abordarão os seguintes temas:

- Caracterização dos resíduos

* Lixo seco

* Lixo úmido

* Lixo verde

* Lixo hospitalar

* Lixo domiciliar perigoso (pilhas, baterias, lâmpadas fluorescentes)

- Impactos ambientais gerados pelo lixo

* Contaminação dos corpos hídricos e águas subterrâneas

* Poluição atmosférica

* Proliferação de vetores

- Reciclagem

Política dos 3 Rs (reduzir, reutilizar e reciclar)

Benéficos da reciclagem

* Tipos de materiais recicláveis

* Processos de reindustrialização de materiais recicláveis

* Comercialização de recicláveis

* Coleta seletiva

* Usina de reciclagem

* Destinação final

* Lixão

* Aterro sanitário

* Aterro de inertes 